$$
\text { UNIVERSIDADE DE SÃO PAULO }
$$

FACULDADE DE FILOSOFIA, LETRAS E CIÊNCIAS HUMANAS

DEPARTAMENTO DE LINGUÍSTICA

PROGRAMA DE PÓS-GRADUAÇÃO EM SEMIÓTICA E LINGUÍSTICA GERAL

CONRADO MOREIRA MENDES

\title{
SEMIÓTICA E MÍDIA: \\ UMA ABORDAGEM TENSIVA \\ DO FAIT DIVERS
}

Versão corrigida

São Paulo

2013 


\section{CONRADO MOREIRA MENDES}

conradomendes@yahoo.com.br

\section{SEMIÓTICA E MÍDIA: UMA ABORDAGEM TENSIVA DO FAIT DIVERS}

Tese apresentada ao Programa de Pós-Graduação em Semiótica e Linguística Geral do Departamento de Linguística da Faculdade de Filosofia, Letras e Ciências Humanas da Universidade de São Paulo, para obtenção do título de Doutor em Semiótica e Linguística Geral.

Orientador: Prof. Dr. Waldir Beividas Área de Concentração: Semiótica e Linguística Geral

De acordo do orientador:

Versão corrigida

São Paulo

2013 
Catalogação na Publicação

Serviço de Biblioteca e Documentação

Faculdade de Filosofia, Letras e Ciências Humanas da Universidade de São Paulo

Mendes, Conrado Moreira
Semiótica e midia: uma abordagem tensiva do fait
divers / Conrado Moreira Mendes ; orientador Waldir
Beividas. - São Paulo, 2013.
282f.
Tese (Doutorado) - Faculdade de Filosofia, Letras
e Ciências Humanas da Universidade de São Paulo.
Departamento de Linguística. Área de concentração:
Semiótica e Linguística Geral.
$\begin{aligned} & \text { 1. Semiótica 2. Análise dos discursos verbais e não } \\ & \text { verbais 3. Fait divers }\end{aligned}$




\section{FOLHA DE APROVAÇÃO}

Nome: MENDES, Conrado Moreira

Título: Semiótica e mídia: uma abordagem tensiva do fait divers

Tese apresentada ao Programa de Pós-Graduação em Semiótica e Linguística Geral do Departamento de Linguística da Faculdade de Filosofia, Letras e Ciências Humanas da Universidade de São Paulo, para obtenção do título de Doutor em Semiótica e Linguística Geral.

APROVADO EM 09/08/2013

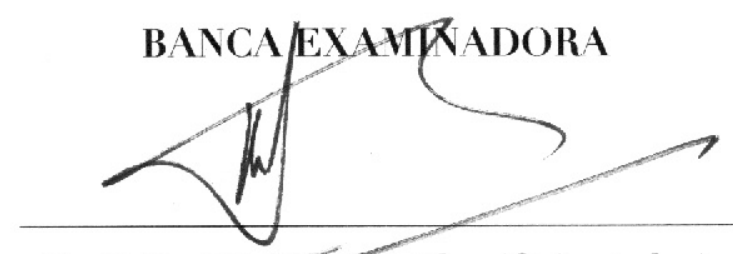

Prof. Dr. Wattrr Beividas (Orientador)

Universidade de São Paulo (USP)

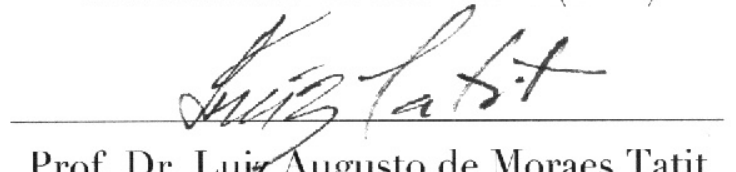

Prof. Dr. Luir Augusto de Moraes Tatit

Universidade de São Paulo (USP)
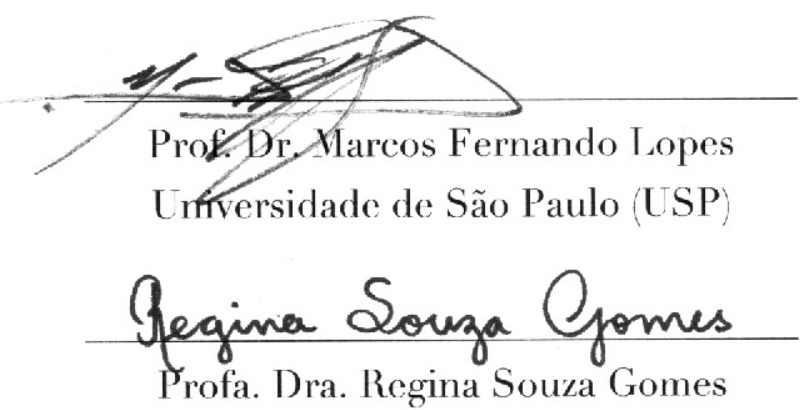

Universidade Federal do Rio de Janeiro (UFRJ)

Universidade Estadual Paulista "Júlio de Mesquita Filho" (UNESP)

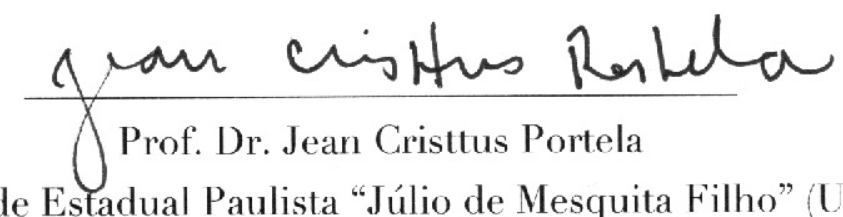


[ESTE TRABALHO FOI REALIZADO GRAÇAS À BOLSA DE ESTUDOS OUTORGADA PELA FUNDAÇÃO DE AMPARO À PESQUISA DO ESTADO DE SÃO PAULO - FAPESP.] 
"Minha mãe achava estudo a coisa mais fina do mundo. Não é. A coisa mais fina do mundo é o sentimento."

Adélia Prado 
Para Wellington e Mirian Chrystus. 


\section{AGRADECIMENTOS}

Ao Prof. Dr. Waldir Beividas, intelectual singular e orientador sempre zeloso, que me acolheu no Programa de Pós-Graduação em Semiótica e Linguística Geral da Universidade de São Paulo, pelas inúmeras contribuições ao longo deste percurso.

À Fundação de Amparo à Pesquisa do Estado de São Paulo (FAPESP), pela bolsa outorgada, com a qual tive o privilégio de poder dedicar-me exclusivamente à pesquisa, em condições dignas, durante o período de meu doutorado.

Extensivamente, agradeço ao parecerista da FAPESP, que acompanhou o desenvolvimento deste trabalho, pela leitura atenta do projeto e dos relatórios, bem como pelas contribuições.

Agradeço pela bolsa "Programa de Doutorado no País com Estágio no Exterior" (PDEE), concedida pela Coordenação de Aperfeiçoamento de Pessoal de Nível Superior (CAPES), com a qual pude desenvolver parte fundamental de minha pesquisa de doutorado na Université Paris VIII, França.

Ao Prof. Dr. Denis Bertrand, orientador no período de estágio doutoral na Université Paris VIII - Vincennes Saint-Denis, pelas preciosas indicações sobre a temática do fait divers.

Agradeço as considerações e os caminhos apontados pelos membros da banca de qualificação, Prof. Dr. José Luiz Fiorin e Prof. Dr. Luiz Augusto de Moraes Tatit. Este trabalho, certamente, não teria sido o mesmo sem a contribuição de vocês. 
Aos membros da banca de defesa, Prof. Dr. Luiz Augusto de Moraes Tatit, Prof. Dr. Marcos Fernando Lopes, Prof ${ }^{\mathrm{a}}$. Dra . Regina Souza Gomes e Prof. Dr. Jean Cristtus Portela que, gentilmente, dispuseram-se a avaliar este trabalho; pela leitura atenta e pelas arguições que, com toda a certeza, trarão subsídios para um diálogo enriquecedor e estímulos para outras reflexões.

Agradeço de maneira especial à Carolina Tomasi, pela acolhida e pela companhia: amiga e debatedora de semiótica de todas as horas.

Ao João Bosco Medeiros, pelas palavras de amizade e de sabedoria.

Às professoras da Universidade Federal de Minas Gerais, Prof ${ }^{\mathrm{a}}$. Dr ${ }^{\mathrm{a}}$. Ana Cristina Fricke Matte e Prof ${ }^{a}$. Dr ${ }^{\mathrm{a}}$. Glaucia Muniz Proença Lara, sem as quais não estaria defendendo uma tese em semiótica. Vocês têm participação decisiva nos caminhos que me levaram ao universo da significação.

Faço um agradecimento especial à Prof ${ }^{a}$. Dr ${ }^{a}$. Regina Souza Gomes, que se tornou uma querida amiga no estágio doutoral, pelas conversas enriquecedoras sobre semiótica e sobre a vida.

Agradeço, finalmente, aos professores do Programa de Pós-Graduação em Semiótica e Linguística Geral, pelas contribuições diretas e indiretas a esta tese; aos funcionários do Departamento de Linguística; aos colegas do Programa de Pós-Graduação em Semiótica e Linguística Geral e do Grupo de Estudos Semióticos da Universidade de São Paulo (GESUSP), que me acompanharam durante esta trajetória. 
Agradeço à minha mãe, Rachel, por ser para mim o que é.

Aos meus avós, às tias Cíntia, Ciara e Cira; a Mariana, Luiza e D. Lourdes.

À Carolina Salomé, pela presença sempre constante. Pelos diálogos instigantes. Pela amizade.

Ao Dimitri, pelo auxílio inestimável.

Ao amigo Marcelo Dias, pela convivência e paciência durante minha permanência em São Paulo.

A Thaís Elena, Priscilla, Silvia Amélia, Roger, Joyce, Carolina Macedo, Daniervelin e Gerlane.

À Claudia Penido, que se tornou uma amiga muito especial a partir da convivência na Maison du Brésil.

À Katia Becho, companhia sempre agradável nas ruelas e bulevares parisienses, e também nas montanhas de Minas.

Aos amigos feitos no período em que vivi em Paris no estágio doutoral: Gabi, Tati, Ana, Heraldo, Mariana e Wescley.

Faço um especial agradecimento à Dra . Telma Weiss, pela escuta.

Agradeço ainda à Dr ${ }^{\mathrm{a}}$. Maria Cristina Bechelany, que contribuiu para que eu reouvesse condições de seguir adiante.

Ao Guy, por tornar minhas manhãs mais felizes. 
Agradeço, enfim, a todos aqueles que estiveram presentes durante minha formação como intelectual e como ser humano.

Esta tese não é senão a concretização de um projeto de vida.

Obrigado. 


\section{RESUMO}

MENDES, Conrado Moreira. Semiótica e mídia: uma abordagem tensiva do fait divers. 2013. 282 f. Tese (Doutorado) - Faculdade de Filosofia, Letras e Ciências Humanas, Universidade de São Paulo, 2013.

Com base nas proposições da semiótica de vertente tensiva, esta tese se ocupa da análise e da teorização do fait divers, categoria jornalística que se refere a eventos de caráter fortuito. O corpus da pesquisa constitui-se primordialmente da cobertura do Caso Isabella Nardoni, compreendido sob a rubrica dessa expressão, realizada pelo Jornal Nacional nos meses de março, abril e maio de 2008. Também compõem o corpus da investigação outros relatos jornalísticos dessa natureza, tanto os que se pautam por uma curta duração quanto aqueles que repercutem na mídia por um período considerável. Em relação ao caso aludido, impôs-se a questão teórica que se refere à pouca duração que um relato noticioso de tal categoria costuma ter. Ao contrário, ele arrastou-se por meses a fio no primeiro semestre de 2008, mantendo, não obstante, uma elevada carga tímica. Dessa forma, procurouse buscar nos mecanismos do discurso as estratégias usadas pelo enunciador "Jornal Nacional" para "extensivizar" a intensidade do Caso Isabella Nardoni, o qual se baseia numa estrutura acontecimental e que, por definição, deveria ser muito intenso, mas pouco extenso. Para tanto, a pesquisa se valeu dos seguintes eixos analíticos: concessão e fidúcia, duração e intensidade, a paixão coletiva da comoção e, por fim, relações intertextuais e interdiscursivas que o texto em análise permite estabelecer com outros textos/discursos. Os referidos eixos cumpriram cada qual a tarefa de responder parcialmente o porquê de, a despeito do transcurso da temporalidade, a intensidade em torno do caso enfocado ter sido duradoura. A partir deles, pôde-se depreender um enunciatário em cujo campo de presença a tonicidade se projeta sobre a temporalidade, criando um efeito de persistência. Tal enunciatário é ainda marcado por uma espera tensa, que quer atenuar o impacto do acontecimento, ao mesmo tempo em que ele reverbera ou irrompem novos microacontecimentos. Verificou-se também a presença de um enunciatário comovido, cujo estado emocional funciona à maneira de uma amálgama, fazendo dele parte de um todo coletivo, social. Esse mesmo enunciatário mostra-se modalizado por um querer-saber, cuja expectativa é também sobredeterminada por outros textos e discursos com os quais o caso em questão estabelece relações intertextuais e interdiscursivas. É, em suma, um enunciatário que se configura na tensão e na complexidade dos eixos da intensidade e da extensidade, o que explica a duração extensa do Caso Isabella Nardoni. Quanto à leitura semiótica dos 
demais faits divers, puderam ser observadas as seguintes (in)variantes: todos se ancoram numa base concessiva, todos são perpassados por uma lógica passional, patêmica. Entretanto, nem todos se pautam por um longo período de repercussão. Pelas recorrências observadas no corpus, balizadas pelas esquizias tensivas primordiais intensidade $\mathrm{e}$ extensidade, foram depreendidas as categorias duração (do menos durativo ao mais durativo) e memória (do menos memorável ao mais memorável), além do elemento constitutivo paixões. A partir disso, pôde-se fundamentar uma abordagem tensiva do fait divers. Finalmente, a análise de um relato noticioso durativo, "raro", que, por meio da estratégia discursiva que "extensiviza" o intenso, demonstrou de que maneira pode ser possível uma articulação dos regimes discursivos do acontecimento e do exercício a partir de um ponto de vista tensivo e, portanto, complexo.

Palavras-chave: Discurso jornalístico. Semiótica tensiva. Fait divers. Duração. Acontecimento. Semiótica midiática. 


\begin{abstract}
MENDES, Conrado Moreira. Semiotics and media: a tensive approach to fait divers. 2013. 282 f. Thesis (Ph.D.) - Faculdade de Filosofia, Letras e Ciências Humanas, Universidade de São Paulo, 2013.
\end{abstract}

Based on the propositions of tensive semiotics, this thesis is concerned with analysing and theorizing the fait divers, a journalistic category that refers to fortuitous events. The corpus of the research primarily consists of the cover of the so-called Isabella Nardoni Case conducted by Brazilian television news program Jornal Nacional in March, April and May 2008. Other journalistic reports of the same nature also comprise the corpus of research, both those outlined in a short duration and those that impact on the media for a considerable period. Regarding the mentioned case, a theoretical question prevailed that refers to little if any lasting that a news report in this category usually has. Instead, it dragged on for months in the first half of 2008, whilst retaining a large thymic load. Thus, we tried to search in discourse mechanisms the strategies used by the enunciator "Jornal Nacional" to "extensiveing" the intensity of Isabella Nardoni Case, which is anchored in an event structure and, by definition, should be very intense but little extensive. Therefore, the research employed the following analytical axes: concession and confidence, duration and intensity, the collective passion of the commotion and, finally, intertextual and interdiscursive relations with other texts/discourses that the text under analysis allows to establish. These analytical axes fulfilled the task of partially answer why, despite the passing of temporality, the intensity surrounding the focused case was lasting. From them, we could deduce an enunciatee in whose presence field tonicity is projected on temporality, creating an effect of persistence. This enunciatee is also marked by a tense wait, who wants to soften the impact of the event, while it reverberates or triggers new micro-events. The presence of an affected enunciatee was also observed, whose emotional state works in the manner of an amalgam, making him a part of a collective, social whole. The same enunciatee proved modalized by a want-to-know whose expectation was also overdetermined by other texts and discourses with which the case in question established intertextual and interdiscursive relations. He is, in short, an enunciatee that is configured in the tension and complexity of the axes of intensity and extent which explains the considerable duration of Isabella Nardoni Case. As for the semiotic reading of other faits divers, we could observe the following (in) variants: all of them are stand on a concessive basis, all pervaded by a 
passionate logic. However, not all are marked by a considerable duration. Through the recurrences observed in the corpus, marked out by a sine qua non relationship between intensity and extent, we inferred the categories duration (from least to most durative) and memory (from least to most memorable), and also the constitutive element passions. From this we could substantiate a tensive approach to fait divers. Finally, the analysis of a durative, "rare", news report which through the discursive strategy "extensivize" the intensity demonstrated how an articulation of discursive regimes of the event and exercise from a tensive and therefore complex point of view may be possible.

Keywords: Journalistic discourse. Tensive semiotics. Fait divers. Duration. Event. Media semiotics. 


\section{RÉSUMÉ}

MENDES, Conrado Moreira. Sémiotique et les médias: une approche tensive du fait divers. 2013. 282 f. Thèse (Doctorat) - Faculdade de Filosofia, Letras e Ciências Humanas, Universidade de São Paulo, 2013.

Fondée sur les propositions de la sémiotique tensive, cette thèse s'occupe de l'analyse et de la théorisation du fait divers, catégorie journalistique qui se rapporte à des événements fortuits. Le corpus de la recherche est constitué avant tout de la couverture de ce qu'on a appelé l'Affaire Isabella Nardoni, accomplie par l'émission de la TV brésilienne Jornal Nacional aux mois de mars, avril et mai 2008. Comprenant aussi le corpus de recherche d'autres récits journalistiques de cette nature dont sont guidés par une courte durée autant que ceux qui ont des répercussions sur les médias pour une période considérable. En ce qui concerne le cas visé, une importante question théorique se réfère à peu de durée qu'un bulletin de nouvelles de cette catégorie manifeste habituellement. En revanche, il s'est traîné pendant des mois dans la première moitié de 2008, tout en conservant une charge thymique élevée. Ainsi, nous avons essayé d'obtenir dans les mécanismes du discours les stratégies discursives utilisées par l'énonciateur «Jornal Nacional " pour “ extensiviser » l'intensité de l'Affaire Isabella Nardoni, qui est ancrée dans une structure événementielle et qui, par définition, devrait être très intense, mais peu extense. Pour cela, la recherche a utilisé les axes analytiques suivantes: concession et fiducie, durée et intensité, la passion collective de la commotion/émoi et finalement des relations intertextuelles et interdiscursives dont le texte sous analyse permet d'établir avec d'autres textes/discours. Chacun de ces axes d'analyse a rempli la tâche de répondre en partie pourquoi, malgré le cours de la temporalité, l'intensité entourant l'affaire a été durable. D'eux, on pourrait en déduire un énonciataire dont son champ de présence la tonicité se projette sur la temporalité en créant un effet de persistance. Cet énonciataire est aussi marqué par une attente tendue, qui veut atténuer l'impact de l'événement, tandis que l'événement réverbère ou cause l'irruption de nouveaux micro-événements. On a vérifié aussi la présence d'un énonciataire émue, dont l'état émotionnel fonctionne à la manière d'un amalgame, ce qui fait de lui une partie d'un ensemble collectif, social. Ce même énonciataire s'est présenté modalisé par un vouloir-savoir dont l'expectative était également surdéterminée par d'autres textes et d'autres discours avec lesquels l'affaire en question a établi des relations intertextuelles et interdiscursives. Il est, en bref, un énonciataire qui est configuré sur la tension et la complexité des axes d'intensité et 
extensité, ce qui explique la considérable durée de l'Affaire Isabella Nardoni. En ce qui concerne la lecture sémiotique des autres faits divers, ces (in)variantes ont été observés: ils sont tous situés sur une base concessive, ils sont tous imprégnés par une logique passionnel, pathémique. Cependant, pas tous ne sont guidés par une durée considérable. Par des récurrences observées dans le corpus, balisées par le rapport entre intensité et extensité, on a déduit les catégories durée (du moins duratif au plus duratif) et mémoire (du moins mémorable au plus mémorable), et aussi l'élément constitutif passions. À partir de là on a pu attester la pertinence d'une approche tensive du fait divers. Enfin, l'analyse d'un bulletin de nouvelles duratif, “ rare », qui au moyen de la stratégie discursive qui “ extensivise " l'intense, a démontré comment il peut être possible d'articuler des régimes discursifs de l'événement et de l'exercice d'un point de vue tensif et donc complexe.

Mots-clés: Discours journalistique. Sémiotique tensive. Fait divers. Durée. Événement. Sémiotique médiatique. 


\section{SUMÁRIO}

INTRODUÇÃ̃O

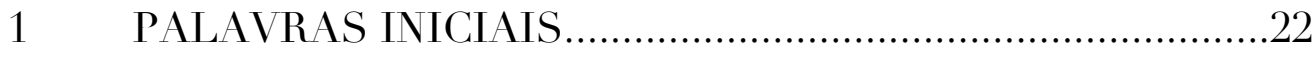

2 A PESQUISA CIENTÍFICA.........................................28

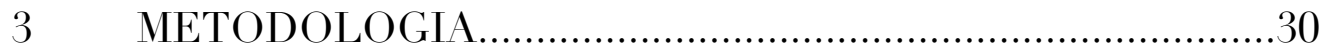

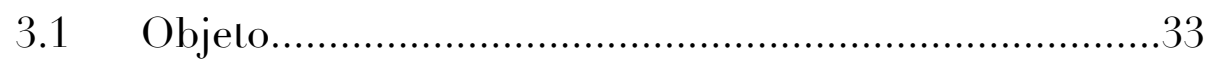

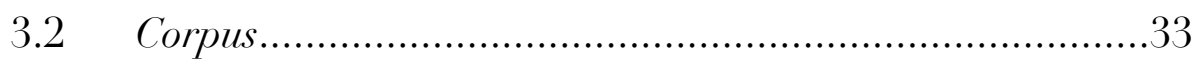

3.2.1 Pequeno relato sobre o Caso Isabella Nardoni...37

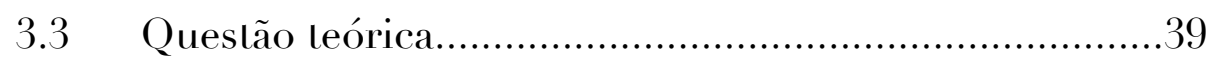

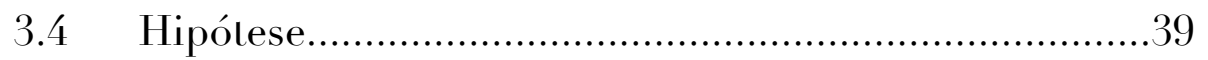

$3.5 \quad$ Justificativas.................................................... 42

3.5.1 Justificativa geral......................................... 42

3.5.2 Justificativa específica....................................49

3.6 Objetivos......................................................51

3.6.1 Objetivo geral..............................................51

3.6.2 Objetivo específico....................................51

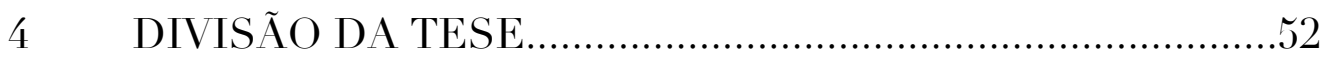

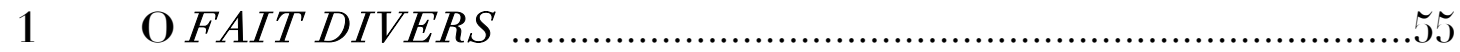

1.1 ORIGENS DO FAIT DIVERS .....................................56

1.2 FAIT DIVERS NO BRASIL ..........................................58

1.3 FAIT DIVERS E SENSACIONALISMO ............................63

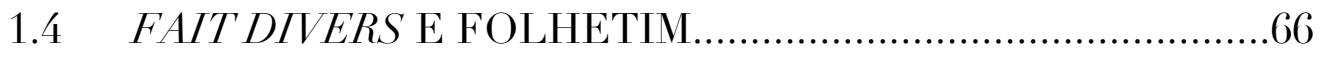

1.5 O MELODRAMA........................................................70

1.6 O FASCÍNIO PELO FAIT DIVERS...................................75

1.7 ESTRUTURA BARTHESIANA DO FAIT DIVERS..............79

1.8 SEMIÓTICA TENSIVA E FAIT DIVERS: primeiras aproximações .84 
2.1 SEMIÓTICA TENSIVA: sobre o contínuo e o afeto...............89

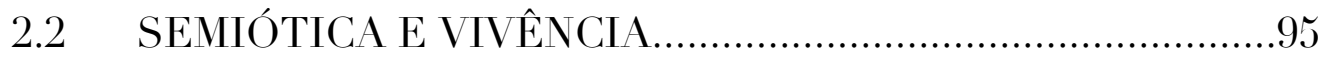

2.3 ALGUNS CONCEITOS PRIMORDIAIS ...........................101

2.3.1 Moedas de troca do sensível: mais e menos..................101

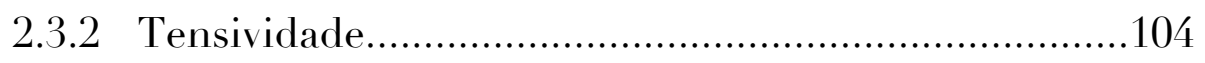

2.3.3 Dimensões e subdimensões....................................107

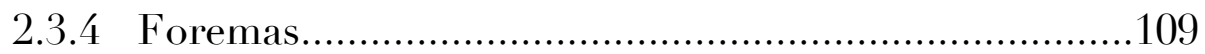

2.4 SINTAXE E SEMÂNTICA TENSIVAS .............................110

2.5 ESTILOS DISCURSIVOS: acontecimento e exercício.........112

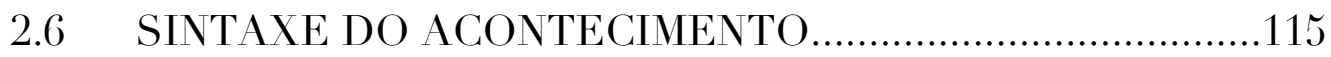

2.7 ACONTECIMENTO E JORNALISMO..............................118

3 ANÁLISES: tensividade e faits divers .......................................124

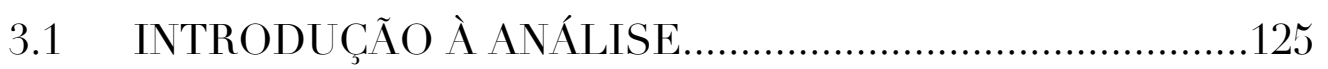

3.2 COBERTURA DO CASO ISABELLA NARDONI PELO

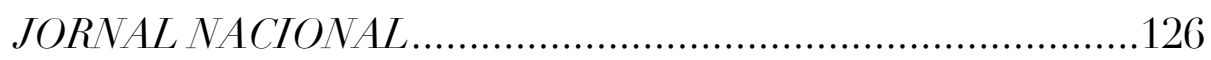

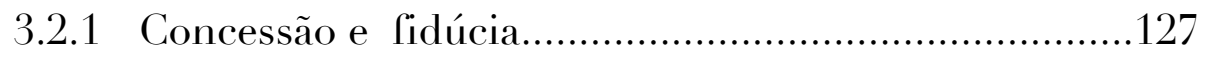

3.2.1.1 Análise I .........................................131

3.2.2 Duração e intensidade: do acontecimento aos microacontecimentos..................................................... 154

3.2.2.1 Acontecimento extenso........................155

3.2.2.2 Acontecimento reverberado..................157

3.2.2.3 Análise II ........................................159

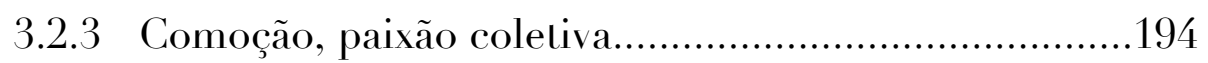

3.2.3.1 Análise III......................................197

3.2.4 Tensividade e relações intertextuais/interdiscursivas..211

3.2.4.1 Relações intertextuais.........................213

3.2.4.1.1 Análise IVa....................215

3.2.4.2 Relações interdiscursivas.....................220

3.2.4.2.2 Análise IVb......................221 
3.3 LEITURA SEMIÓTICA DE OUTROS FAITS

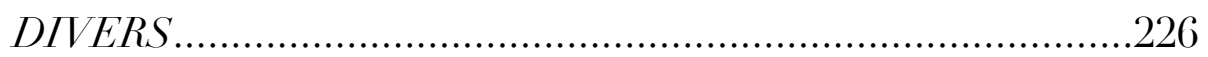

3.3.1 Reportagem de $O$ Globo................................227

3.3.2 Reportagem do Jornal Nacional.......................231

3.3.3 Outros faits divers de grande repercussão........233

3.3.3.1 Caso von Richthofen...................233

3.3.3.2 Caso Eloá Pimentel.....................238

4 UMA ABORDAGEM TENSIVA DO FAIT DIVERS ................243

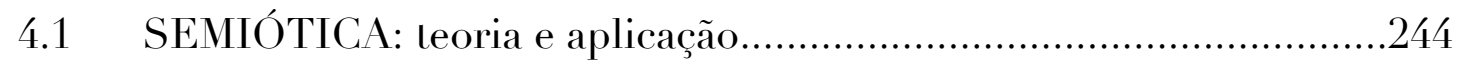

4.2 O FAIT DIVERS À LUZ DA TENSIVIDADE..............................244

4.2 .1 Duração....................................................................245

4.2 .2 Memória.......................................................................248

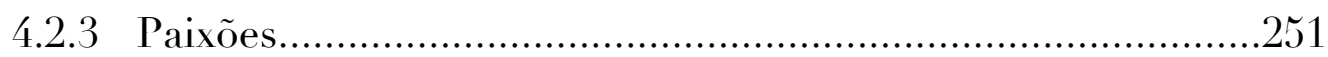

4.3 TIPOLOGIA TENSIVA DO FAIT DIVERS .................................253

4.4 FAIT DIVERS, ACONTECIMENTO E EXERCÍCIO.....................255

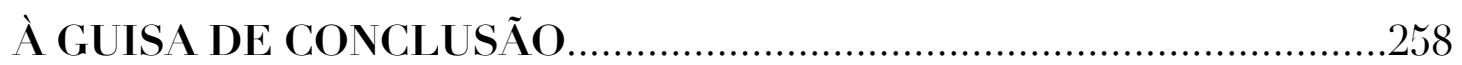

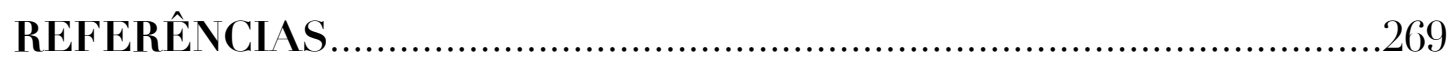


[Introdução]

"Au commencement était l'affect..."

Claude Zilberberg 


\section{PALAVRAS INICIAIS}

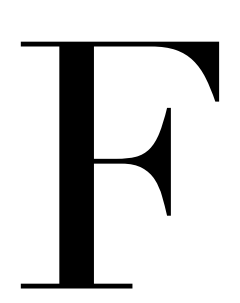

ait divers, conforme a tradução literal do francês poderia sugerir, designaria tão somente um fato diverso, diferente. Fait (fato, do latim factum), particípio passado de faire (fazer, do latim facere), é a "realização de uma coisa, maneira de fazer, maneira de agir", indica o Trésor de la langue française. Segundo a mesma fonte, divers refere-se àquilo "que apresenta aspectos opostos, contraditórios". A etimologia latina do segundo termo da expressão revela ainda significados inesperados. Vejamos, pois, quais são eles.

Divers provém do latim diversus, particípio passado de divertère, mostra o referido dicionário francês. O brasileiro Houaiss também indica que diverso, “apartado, afastado" e, por extensão, “oposto, adverso", no latim tardio, redundou em diversio, "digressão, diversão". "Apartar-se" ou "afastar-se" pressuporia, assim, uma disjunção, a partir da qual se originaria o "estranho": aquilo que é de fora, do latim extranèus, segundo o mesmo dicionário.

O fait divers constitui-se, dessa forma, preliminarmente, como o outro, o não eu. Por esse prisma, ele pode ser tomado como uma alteridade que diverte, que entretém, que faz rir e da qual se escarnece. Essa pequena digressão etimológica sugere, portanto, que a expressão comporta mais sentidos que um simples "fato diverso".

\footnotetext{
${ }^{1}$ As traduções dos trechos em língua estrangeira citados são de nossa autoria.
} 
A expressão francesa, que não encontra correspondente em português ${ }^{2}$, é apresentada sucintamente no Trésor de la langue française como: "Eventos do dia reportados pela imprensa". Do mesmo modo, o Houaiss insere o verbete no campo semântico do jornalismo, da radiofonia e da televisão, definindo-o como: "Assuntos variados; variedades”, ou, ainda, “Notícias de pouca importância num jornal”.

O Grand Dictionnaire Universel du XIXe siècle, de Pierre Larousse, por sua vez, apresenta o verbete com muito mais riqueza descritiva:

Sob essa rubrica, os jornais agrupam com arte e publicam regularmente todo tipo de notícias que correm pelo mundo: pequenos escândalos, acidentes de carros, crimes hediondos, suicídios por amor, pedreiro caído do quinto andar, assaltos, chuvas de gafanhotos ou de sapos, naufrágios, incêndios, inundações, aventuras burlescas, sequestros misteriosos, execuções fatais, casos de hidrofobia, de antropofagia, de sonambulismo, de letargia $[. .$.$] fenômenos da natureza [. .$. bezerros de duas cabeças, [...] gêmeos grudados pelo ventre, criança com três olhos, anões extraordinários, etc.

O termo, que remonta à imprensa do século XIX, nomeia, portanto, notícias que não se enquadram nas editorias tradicionais do jornalismo, como política, economia, cultura, internacional, etc. Barthes (1964) foi o primeiro teórico a lançar luz sobre esse tipo de relato da ordem do inusitado, do monstruoso e, por vezes, do privado. A especificidade da abordagem barthesiana reside em conjecturar uma estrutura para ofait divers.

É também pela estruturação desse tipo de relato que se interessa nossa investigação de doutorado. A breve exposição a respeito da definição

\footnotetext{
${ }^{2}$ Em inglês, entretanto, fait divers tem sentido correlato à expressão features (Cf. SODRÉ, 2009, p. 223).
} 
de fait divers introduz, assim, o objeto desta pesquisa. Diferentemente da perspectiva semiológica, entretanto, analisamos e teorizamos o fait divers à luz de recentes desdobramentos da teoria semiótica de linha francesa, que priorizam a questão do sensível, sobretudo a semiótica tensiva (Cf. FONTANILLE; ZILBERBERG, 2001; ZILBERBERG, 2007; 2011a; 2011b): uma "gramática do afeto", no dizer de Zilberberg (2011a, p. 12).

Nosso corpus constitui-se, primordialmente, mas não apenas, da cobertura do Caso Isabella Nardoni, realizada pelo Jornal Nacional, noticiário exibido de segunda-feira a sábado, às 20h30min, pela Rede Globo de Televisão. Exaustivamente noticiado pela mídia brasileira em 2008, o episódio gira em torno do assassinato de Isabella Nardoni, de cinco anos. Os suspeitos, à época, foram o próprio pai, Alexandre Nardoni, e a madrasta, Anna Carolina Jatobá. Tal desconfiança se comprovou ao longo da investigação: de indiciados pelo crime, foram acusados e condenados pela justiça. Conforme narrou a imprensa, a menina foi ferida, asfixiada e, por fim, jogada pela janela do sexto andar do apartamento do pai. Isabella passava o final de semana com ele, a madrasta e os dois filhos do casal. Socorrida pelos bombeiros, a criança morreu a caminho do hospital. O evento caracteriza, segundo o conceito de Barthes (1964), um fait divers: é uma notícia da ordem do inesperado, de natureza transgressora e assombrosa.

A manchete "Menina morre ao cair de prédio", título da primeira reportagem do noticiário Jornal Nacional sobre o caso, alastrou-se de forma epidêmica, sendo repetida, parafraseada, recontada pelos mais diversos meios: programas de televisão e de rádio - não apenas os de caráter noticioso -, jornais impressos, revistas semanais e portais da internet. $O$ 
rosto de Isabella, até então desconhecido, tornou-se onipresente na esfera midiática. Todos tentavam, perplexos, compreender aquele evento de natureza tão brutal. Às primeiras notícias sobre o Caso Isabella Nardoni, seguiram-se muitas, uma infinidade delas.

A cobertura midiática do assassinato da menina arrastou-se por meses a fio no primeiro semestre de 2008, e os meios de comunicação reportaram, ad nauseam, informações sobre o ocorrido. Para se ter uma ideia da dimensão do Caso Isabella Nardoni, uma pesquisa realizada pelo Instituto CNT/Sensus em abril daquele ano mostrou que $98,2 \%$ da população tinha conhecimento do assassinato (Cf. VAZ; FRANÇA, 2009, p. 13). Para esses autores, "trata-se de um recorde, tornando-o o crime mais conhecido entre os brasileiros".

A longa extensão da cobertura desse fait divers, cujo conceito, paradoxalmente, define-se como algo necessariamente breve e de memória muito curta (BARTHES, 1964, p. 195), foi pouquíssimas vezes registrada pelos meios de comunicação brasileiros. Estamos, assim, indubitavelmente frente a um fait divers singular.

Nossa questão teórica, desse modo, gira em torno de um paradoxo entre a extensão da cobertura midiática do Caso Isabella Nardoni e de dois conceitos, que, a nosso ver, apresentam afinidades. O primeiro é a definição barthesiana de fait divers (BARTHES, 1964). O segundo é o conceito de acontecimento [événement], cunhado no âmbito dos estudos semióticos (ZILBERBERG, 2007, 2011a), o qual, grosso modo, traduz-se por um fato semiótico que adentra de forma abrupta o campo de presença do sujeito, com intensidade (sensível) paroxística e extensidade (inteligível) mínima; 
nesses termos, o acontecimento sobrevém: é da ordem do inesperado. Elucidemos melhor a maneira como tal problema nos é colocado.

Não obstante Alencar (2005, p. 119), na esteira do semiólogo francês, assumir que o fait divers não possui serialidade, a imprensa, especificamente neste trabalho, a brasileira, registra, ainda que com menos frequência, fatos cujas coberturas não se desenvolvem em poucos dias e apresentam, sim, um caráter sequencial. Embora o Caso Isabella Nardoni possa ser considerado um contraexemplo da definição barthesiana de fait divers no que se refere à brevidade, à não serialidade, ele se enquadra na categoria do semiólogo francês devido a seu caráter brutal e por se caracterizar como um evento imprevisto.

Valemo-nos da asserção de Ramos (2008, p. 137) para corroborar a ideia da serialidade do fait divers em questão: "A notícia [do Caso Isabella Nardoni] impactou o território nacional. Foi apropriada e explorada pela Mídia, impressa e eletrônica, por vezes, como se fosse uma novela, escrita e roteirizada pelo interesse jornalístico" (itálicos nossos). Trata-se, portanto, de uma ocorrência de natureza durativa e sequencial.

Por tal motivo, o que mais chama atenção no Caso Isabella Nardoni é sua extensidade, o longo período em que ficou em evidência. A mídia brasileira, por quase três meses ininterruptamente, veiculou incontáveis notícias sobre o episódio. Não é exagero dizer que o caso foi um dois mais noticiados da primeira década do século XXI, haja vista a já mencionada pesquisa do Instituto CNT/Sensus. Poucos fatos como esse motivaram 
tamanho clamor público, tamanha comoção social, e em torno do qual a memória coletiva, cumpre afirmar, mantém-se viva ${ }^{3}$.

Nesses termos, o problema desta tese pode ser resumido da seguinte maneira: como, a partir de um evento pontual, ou seja, a morte da menina Isabella, o discurso midiático promoveu uma das coberturas mais longas da década? Ou, ainda, pela metalinguagem semiótica: de que modo se pode explicar discursivamente o interesse contínuo do enunciatário pelo Caso Isabella Nardoni e, ainda, quais foram as estratégias do enunciador "Jornal Nacional" para fazer perdurá-lo, ou, mais que isso, "extensivisar" a intensidade de um acontecimento (Cf. ZILBERBERG, 2007, 2011a) que se define, preliminarmente, por ser muito intenso e, justamente por isso, pouco extenso?

Para tanto, analisamos o corpus da pesquisa ancorados na semiótica tensiva, cuja base de articulação é o entrecruzamento da intensidade com a extensidade, o que por sua vez permite à teoria dar conta do afeto e do acontecimento. Logo, tais postulados mostram-se adequados como instrumental teórico-metodológico à presente investigação. Cabe dizer, contudo, que o ponto de vista tensivo da semiótica foi concebido em complemento e não em substituição à teoria greimasiana, da qual também nos valemos à medida de sua necessidade, ou seja, sempre que conceitos da teoria semiótica narrativa e discursiva forem convocados pela análise, conforme demonstrado no Capítulo 3.

Enfim, é com base sobretudo na noção de tensividade que direcionaremos nossa pesquisa. Visamos, dessa maneira, a estabelecer um

\footnotetext{
${ }^{3}$ Discorremos sobre essa asserção no Capítulo 3 e a teorizamos no Capítulo 4.
} 
modelo para responder às questões suscitadas pelo corpus. Tal modelo resulta num conjunto de categorias que dão suporte para a proposição de uma abordagem tensiva para esse tipo de relato, na qual suas as intensidades e extensidades possam ser contempladas.

\section{A PESQUISA CIENTÍFICA}

Uma pesquisa científica deve se apresentar num registro de linguagem próprio a esse gênero acadêmico, no qual, quase que invariavelmente, veem-se apagadas as marcas do enunciador "pesquisador". O intuito, nas palavras de Greimas (1976, p. 10), é o de construir “o discurso da não pessoa, que não pertence a ninguém, ou seja, como o discurso objetivo, cujo sujeito seria a ciência a fazer-se por si mesma". Ainda segundo o autor (GREIMAS, 1983, p. 110), trata-se de uma “camuflagem objetivante": o discurso científico, para ser sancionado positivamente, ou seja, ser aceito como verdadeiro, tenta se passar como se não fosse o discurso do sujeito, "mas como o puro enunciado das relações entre as coisas, apagando, na medida do possível, todas as marcas da enunciação".

Entretanto, sendo a enunciação a instância linguística logicamente pressuposta ao enunciado (GREIMAS; COURTÉS, 2008, p. 166-168), haverá sempre um sujeito, também pressuposto, que produziu esse dizer. A subjetividade, portanto, implica qualquer atividade discursiva:

[A] "subjetividade", quer a apresentemos em fenomenologia ou em psicologia, como quisermos, não é mais que a emergência no ser de uma propriedade fundamental da linguagem. É 'ego' que diz ego. Encontramos aí o fundamento da "subjetividade" que se determina pelo status linguístico da "pessoa" (BENVENISTE, 2005, p. 286). 
Logo, não seria novidade para ninguém, estamos falando de efeito de objetividade, já que a "objetividade em si” é puramente ilusória. Greimas (1976, p. 53), ao finalizar seu ensaio sobre o discurso científico nas humanidades, afirma:

Tende este $[o$ discurso da pesquisa $]$ a se fazer passar, a qualquer preço - astúcia e vocação ao mesmo tempo - por um discurso objetivo e socioletal, cujo sujeito seria, a um tempo, um actante coletivo e alguém; o pesquisador-locutor seria apenas o autor-delegado, com o discurso da descoberta, necessariamente personalizado, mas inscrito, como se pode entrever, num algoritmo subjacente, que o rege camufladamente. Relações paradoxais entre o discurso social que não consegue esconder seus laços com o enunciador singular que o produz, e o discurso individual que se deixa guiar por uma finalidade que o ultrapassa.

Dessa maneira, o autor reitera o fato da impossibilidade de um discurso científico neutro, da não pessoa, da plena objetividade. Este é sempre pressuposto e atravessado pelo sujeito que o produziu. É por isso que, por detrás de uma pesquisa científica, cujo discurso tem como finalidade a inalcançável neutralidade e o apagamento do sujeito, haverá sempre um "eu" - ainda que pressuposto.

Por conseguinte, este "eu" que fala, naturalmente, não é o pesquisador de "carne e osso": é um narrador, subsumido pela instância de um enunciador. E, embora não ontológico, o enunciador do discurso científico possui interesses, valores, desejos, conscientes ou não, um ethos, em suma, que se depreende tanto pelo dito quanto pelo dizer - dir-se-ia que até mais pelo dizer, pela enunciação. Por isso, a escolha de um objeto de pesquisa jamais the será indiferente: ela reflete os gostos desse enunciador, seus objetos de interesse, seu universo particular. 
Finalmente, assim como a objetividade do discurso científico, também um mito de raízes positivistas é o da ciência como portadora d' "a verdade". O discurso científico não equivale à verdade "verdadeira", com o perdão do pleonasmo, mas, antes, a uma construção discursiva que obedece procedimentos canônicos, submetidos a critérios de cientificidade. A "verdade" da ciência, dessa forma, observando-se tais elementos, constrói-se por meio de uma coerência interna, de um dizer verdadeiro, da veridicção, enfim, que caracteriza tal gênero acadêmico.

Estamos, assim, cientes dos procedimentos enunciativos que criam efeitos de objetividade/subjetividade. Temos em conta ainda que uma pesquisa não surge $e x$ nihilo, ou seja, não se faz senão por razões que movem o pesquisador: a intensidade é regente da extensidade. Não obstante tais razões, faz-se necessário justificar o empreendimento de uma pesquisa cientifica. Deve-se também explicitar o objeto e o problema por ele suscitado, os objetivos, o corpus, enfim, os procedimentos metodológicos que caracterizam uma investigação e seu respectivo discurso.

\section{METODOLOGIA}

Nosso caminho de investigação científica apoia-se na semiótica tensiva, a qual inclui dois conceitos primordiais: intensidade e extensidade, estados de alma e estados de coisas, respectivamente. A partir de tais eixos, como pode ser visto no Capítulo 2, estabelece-se um espaço tensivo no qual o fait divers é observado pelo viés do continuum, ou seja, como uma fenômeno que implica gradação. 
Ao discurso científico e ao seu respectivo fazer, subjaz o conceito de cientificidade. Segundo Eco (2012, p. 21), é científico um estudo quando se constitui dos seguintes elementos:

(1) Apresenta de forma clara um "objeto reconhecível e definido de tal maneira que seja reconhecível igualmente pelos outros";

(2) O estudo deve ser ainda inédito ou, em nosso caso, realizado a partir de uma perspectiva distinta das que o precedem. Em relação a essa questão, Nohara e Acevedo (2007, p. 83; itálicos nossos) esclarecem:

A originalidade é concretizada em uma investigação quando esta apresenta novas evidências empíricas sobre sua aplicação, ou quando apresenta novos arcabouços teóricos ou novas relações teóricas que relacionam antigos modelos ou princípios teóricos a conceitos emergentes.

(3) Eco (2012, p. 22) expõe ainda que um empreendimento científico deve, ademais, ser útil, pela contribuição deixada por ele.

(4) Por fim, aponta o pensador italiano, uma pesquisa deve "fornecer elementos para a verificação e contestação das hipóteses apresentadas” (ECO, 2012, p. 23), ou seja, fornecer elementos comprobatórios e descrever, objetivar, os procedimentos da investigação.

Assim, a cientificidade pressupõe um método, uma metodologia científica: "corpo de regras e diligências estabelecidas para realizar uma pesquisa; método", segundo assevera o Houaiss. Método, do grego, forma-se por meta (para) e hodos (caminho): "Poder-se-ia, então, traduzir a palavra por 'caminho para' ou, [...] 'prosseguimento', 'pesquisa'”, conforme indicam Laville e Dionne (1999, p. 11). 
Como se sabe, a linguística hjelmsleviana toma para si, em contraposição aos estudos da linguagem anteriores a Saussure, o método dedutivo (HJELMSLEV, 2006, p. 14), a partir do qual se parte do geral em direção ao particular. Segundo Greimas e Courtés (2008, p. 117):

Distinguem-se duas espécies de raciocínio dedutivo: é chamado categórico-dedutivo o que põe como ponto de partida um conjunto de posições declaradas verdadeiras; o raciocínio hipotético-dedutivo contenta-se com supô-las verdadeiras: é o que geralmente é adotado, hoje, em semiótica e em linguística (grifos nossos).

Nossa pesquisa ancora-se na segunda espécie de raciocínio dedutivo exposta pelos autores do Dicionário de semiótica: supomos (cremos-ser) verdadeiras as premissas de que partimos. Isso porque segundo informam ainda Greimas e Courtés (2008, p. 117):

A oposição tradicional entre dedução e indução parece hoje superada: se é verdade que o raciocínio dedutivo preside à construção de uma teoria e ao estabelecimento de sua economia geral, é conhecido e reconhecido que operações locais, de caráter indutivo, são muitas vezes utilizadas para elaborar os conceitos de modelos de alcance mais geral.

É assim também que Greimas e Fontanille (1993, p. 10) entendem o projeto semiótico: dedutivo, porquanto parte de um arcabouço teórico, indutivo, por meio das análises efetuadas, e hipotético a partir das formulações epistemológicas passíveis de serem estabelecidas por meio das análises, com o fito de tornar o modelo teórico mais heurístico. 


\subsection{Objeto}

Um objeto de pesquisa é sempre um corpus delimitado, observado a partir de uma teoria, neste caso, conforme dissemos, a semiótica tensiva. Nosso objeto de pesquisa é o fait divers, categoria do jornalismo em que se inscreve o Caso Isabella Nardoni. O objeto, ressalte-se, não é o caso em si, mas a categoria de relatos que se encontram sob a rubrica de tal expressão.

No entanto, a opção de analisar o referido caso se deve à razão de ser um fait divers do tipo raro, contudo, ao mesmo tempo, por ser um fato representativo, uma vez que outras ocorrências como essa se pautaram por uma repercussão midiática duradoura. Portanto, trata-se de um caso incomum, mas que não é único. A título de comparação, será feita uma leitura de outros faits divers, com características distintas e também correlatas às do Caso Isabella Nardoni. Interessa-nos, assim, observar como se constitui o fait divers à luz da tensividade.

\subsection{Corpus}

O corpus principal a ser analisado se refere à cobertura jornalística do Caso Isabella Nardoni feita pelo Jornal Nacional (JN), telejornal exibido às 20h30min, de segunda-feira a sábado, pela Rede Globo de Televisão, desde $1^{\circ}$ de setembro de 1969 (Cf. ORGANIZAÇÕES GLOBO, 2004). Embora esse fait divers tenha sido veiculado pelos mais diversos canais de televisão, bem como pela mídia impressa e digital, a escolha recaiu sobre o Jornal Nacional ${ }^{4}$

\footnotetext{
${ }^{4} \mathrm{O}$ Caso Isabella Nardoni foi objeto de noticiário e programas de outras emissoras e da própria Rede Globo de Televisão, como o Jornal Hoje e o Fantástico, por exemplo. Ainda assim, pareceu-nos suficiente concentrar nossa análise no Jornal Nacional, "o modelo de
} 
pelo fato de ele ser o noticiário mais assistido da TV brasileira. De acordo com dados do instituto de pesquisas IBOPE, obtidos em Feltrin (2012), o telejornal, invariavelmente, no primeiro trimestre de 2012, ultrapassou os 30 pontos de audiência ${ }^{5}$. O share, porcentagem de televisores ligados na hora em que o noticiário é exibido, por sua vez, é de aproximadamente 55\%. Segundo a Direção Geral de Comercialização da Rede Globo ${ }^{6}$, isso representa 25 milhões de telespectadores, em média, a cada edição. Muito mais que a vendagem de todos os jornais impressos do Brasil juntos num único dia: aproximadamente 4,5 milhões de exemplares em média no primeiro semestre de 2012, segundo dados do Instituto Verificador de Circulação $(\mathrm{IVC})^{7}$.

Ademais, para Ramos (2012, p. 50), "o fait divers se compatibiliza com a linguagem televisiva”. Assim, a linguagem sincrética, audiovisual, constitui, com som e imagem em movimento, a figurativização levada às últimas consequências: a iconização do fait divers, em cujo substrato figural oscilam suas respectivas correlações entre intensidade e extensidade.

referência para o telejornalismo nacional", no entender de Gomes (2005, p. 1). Ainda sobre essa importância, afirma Bonner (2009, p. 11): "Todo mundo conhece o Jornal Nacional. Todo mundo sabe em que canal de TV ele está e a que horas começa. Todo mundo sabe porque costuma assistir ao $\mathrm{JN}$ - e, muito provavelmente, a maioria das pessoas tem, na memória, um momento marcante, inesquecível, de um acontecimento noticiado pelo Jornal Nacional".

${ }^{5}$ Cada ponto de audiência no Painel Nacional de Televisão (PNT) equivale a 192 mil domicílios sintonizados e o cálculo se baseia nas 14 principais regiões metropolitanas do Brasil.

${ }^{6}$ Disponível em: http://comercial.redeglobo.com.br/programacao_jornalismo/jnac5_intro.p hp/. Acesso em: jul. 2012.

${ }^{7}$ Dados obtidos no portal de notícias Terra: Disponível em http://noticias.terra.com.br/ mundo/noticias/0,,oi6017558-ei294,00-jornais + impressos + sobrevivem + e + ainda + crescem + no+brasil+comemoram+editores.html/. Acesso em: jul. 2012. 
Como dissemos, o Caso Isabella Nardoni teve uma das maiores repercussões já vistas nos meios de comunicação brasileiros nos últimos anos. Um exemplo dessa importância é o fato de ter havido, em uma única edição desse noticiário, até quatro reportagens sobre o caso. Cabe dizer que uma edição média do programa "tem 33 minutos líquidos (um tempo que não inclui os intervalos, portanto)" (BONNER, 2009, p. 22) e que o Jornal Nacional tem o objetivo declarado de "mostrar aquilo que de mais importante aconteceu no Brasil e no mundo naquele dia" (BONNER, 2009, p. 19). Por conseguinte, quatro reportagens numa mesma edição demonstram o elevado grau de importância conferido ao caso.

Assim, consideramos um corpus que compreende a cobertura feita pelo Jornal Nacional sobre o Caso Isabella Nardoni entre 31 de março de 2008 a 12 de maio de 2008. Contabilizam-se, dessa maneira, 36 edições do noticiário, nas quais foram exibidas 60 reportagens. Na tabela a seguir, estão dispostas as datas e o número de reportagens por edição:

\begin{tabular}{|c|c|c|c|c|c|}
\hline Data & $\begin{array}{c}\text { Número de } \\
\text { reportagens } \\
\text { por edição }\end{array}$ & Data & $\begin{array}{c}\text { Número de } \\
\text { reportagens } \\
\text { por edição }\end{array}$ & Data & $\begin{array}{c}\text { Número de } \\
\text { reportagens } \\
\text { por edição }\end{array}$ \\
\hline $31 / 03 / 2008$ & 01 & $15 / 04 / 2008$ & 03 & $29 / 04 / 2008$ & 01 \\
\hline $01 / 04 / 2008$ & 01 & $16 / 04 / 2008$ & 01 & $30 / 04 / 2008$ & 02 \\
\hline $02 / 04 / 2008$ & 03 & $17 / 04 / 2008$ & 01 & $01 / 05 / 2008$ & 01 \\
\hline $03 / 04 / 2008$ & 04 & $18 / 04 / 2008$ & 02 & $02 / 05 / 2008$ & 02 \\
\hline $04 / 04 / 2008$ & 04 & $19 / 04 / 2008$ & 03 & $03 / 05 / 2008$ & 01 \\
\hline $05 / 04 / 2008$ & 01 & $21 / 04 / 2008$ & 04 & $05 / 05 / 2008$ & 01 \\
\hline $07 / 04 / 2008$ & 01 & $22 / 04 / 2008$ & 02 & $06 / 05 / 2008$ & 01 \\
\hline $08 / 04 / 2008$ & 01 & $23 / 04 / 2008$ & 01 & $07 / 05 / 2008$ & 02 \\
\hline $09 / 04 / 2008$ & 01 & $24 / 04 / 2008$ & 01 & $08 / 05 / 2008$ & 02 \\
\hline $11 / 04 / 2008$ & 01 & $25 / 04 / 2008$ & 01 & $09 / 05 / 2008$ & 01 \\
\hline
\end{tabular}




\begin{tabular}{|c|c|c|c|c|c|}
\hline $12 / 04 / 2008$ & 02 & $26 / 04 / 2008$ & 01 & $10 / 05 / 2008$ & 01 \\
\hline $14 / 04 / 2008$ & 02 & $28 / 04 / 2008$ & 02 & $12 / 05 / 2008$ & 01 \\
\hline
\end{tabular}

O assassinato da menina ocorreu no dia 29 de março de 2008, sábado. A primeira notícia sobre o caso no Jornal Nacional foi apresentada na segunda-feira, 31 de março. Optamos pelo dia 31 de março pela razão natural de se tratar da primeira reportagem sobre da morte da criança. O dia 12 de maio tampouco foi escolhido de forma aleatória, pois o caso, até essa data, já está relativamente encaminhado. Embora os acusados não tivessem sido ainda julgados e condenados, fato ocorrido dois anos depois, já se encontravam em prisão preventiva. Depois dessa data, notícias sobre o Caso Isabella Nardoni tornaram-se mais esparsas.

As reportagens sobre o caso foram transcritas do site do noticiário (http://g1.globo.com/jornal-nacional/), de onde também foram obtidos os vídeos das reportagens sobre esse fait divers, dos quais são exibidos quadros (frames) no Capítulo 3, dedicado às análises.

Além das 60 reportagens do Jornal Nacional, o corpus deste trabalho constitui-se de uma reportagem do jornal $O$ Globo (Bebê é espancado até a morte, e casal é preso) publicada em 19 de julho de 2012; outra do Jornal Nacional (Motorista de ônibus salva menina que caiu de janela em Nova York), exibida em 17 de julho de 2012. Ademais, tendo em vista outros relatos noticiosos, procuramos observar elementos constitutivos de dois faits divers, que, assim como o Caso Isabella Nardoni, pautaram-se por grande repercussão: os casos von Richthofen e Eloá Pimentel. O objetivo de se apresentar um corpus mais amplo se deve a categorias que daí se 
depreendem, de modo a dar suporte a uma abordagem tensiva do fait divers, apresentada no Capítulo 4.

\subsubsection{Pequeno relato sobre o Caso Isabella Nardoni}

Isabella de Oliveira Nardoni (São Paulo, 18 de abril de 2002 - 29 de março de 2008), de cinco anos, era filha de Ana Carolina Cunha de Oliveira e Alexandre Alves Nardoni. Ana Carolina ficou grávida de Isabella aos 17 anos e nunca chegou a se casar ou a morar junto com o pai da menina. Aos 11 meses de vida do bebê, o casal se separou. A mãe ficou com a guarda da filha, recebendo mensalmente pensão alimentícia paterna.

Alexandre Nardoni uniu-se posteriormente a Anna Carolina Trotta Peixoto Jatobá, com quem teve dois filhos. De acordo com o estabelecido judicialmente, Isabella passava dois finais de semana por mês com o pai. Alexandre e sua família viviam num apartamento de classe média alta num edifício chamado London, no distrito da Vila Guilherme, Zona Norte de São Paulo.

Num desses finais de semana, em 29 de março de 2008, às 23h30, Isabella foi defenestrada do sexto andar do apartamento em que viviam o pai, a madrasta e os dois meios-irmãos. Encontrada ainda com vida, caída no gramado do edifício, a criança apresentava parada cardiorrespiratória e ferimentos na testa. Socorrida por bombeiros, não sobreviveu a caminho do hospital Santa Casa de Misericórdia. 
Iniciou-se uma longa investigação para determinar o(s) responsável (eis) pelo crime. Em 22 de março de 2010, aproximadamente dois anos após a morte de Isabella, foram a júri popular, como réus, o pai e a madrasta da menina. Depois de cinco dias de julgamento, o juiz Maurício Fossen, da $2^{a}$ Vara do Júri do Fórum de Santana, São Paulo, considerou o casal culpado por homicídio triplamente qualificado (morte por asfixia, considerado meio cruel; o fato de a vítima não ter tido a chance de se defender; por estar inconsciente ao ser jogada pela janela). Alexandre Nardoni foi condenado a 31 anos, 1 mês e 10 dias, pelo agravante de ser pai de Isabella. A Anna Jatobá coube a pena de 26 anos e 8 meses. Ambos em regime fechado. Pela fraude processual cometida pelo casal (alterações na cena do crime), a pena foi acrescida de 8 meses e 24 dias em regime semiaberto para cada um.

De forma muito sintetizada, assim pode ser reproduzido o relato sobre Caso Isabella Nardoni, o fait divers de maior repercussão da primeira década dos anos 2000. O caso ressoou, inclusive internacionalmente, como poucas vezes se viu: o Le Monde ${ }^{8}$, por exemplo, afirmou que "O sorriso de Isabella assombra o Brasil". A $\mathrm{BBC}^{9}$ de Londres, por sua vez, noticiou que "Pais da menina brasileira são presos".

O evento, conforme se pode ver, viola todas as regras de conduta estabelecidas socialmente. O progenitor, de quem se espera o zelo pelo bem-

\footnotetext{
8 Disponível em: http://www.lemonde.fr/cgi-bin/achats/acheter.cgi?offre=archives\&type item=art_arch_30j\&objet_id=1035904. Acesso em jul. 2012.

${ }^{9}$ Disponível em: http://news.bbc.co.uk/2/hi/americas/7390390.stm. Acesso em jul. 2012.
} 
estar da filha, revela-se seu assassino. O Caso Isabella Nardoni, portanto, ancora-se numa patente base concessiva ${ }^{10}$.

\subsection{Questão teórica}

Já dissemos, o Caso Isabella Nardoni rompe com a lógica da curta duração e da não serialidade do fait divers, embora reúna elementos que o identifiquem com tal relato jornalístico: "uma informação monstruosa", segundo Barthes (1964, p. 194). Por meses, a cobertura midiática do caso envolvendo a morte da menina Isabella despertou a atenção e a comoção do enunciatário "telespectador". Assim, visamos a analisar as estratégias do enunciador "Jornal Nacional" que mantiveram intacto o interesse desse sujeito. Pela metalinguagem da semiótica tensiva, buscamos depreender os mecanismos pelos quais, malgrado a extensidade, a intensidade tenha se mantido alta durante meses. Por outro lado, cumpre observar por que a maioria dos faits divers se caracteriza pela não serialidade e pelo posterior rápido esquecimento.

\subsection{Hipótese}

Nossa hipótese se ancora no fato de o fait divers ser portador de uma elevada carga tímica, o que implica analisar a afetividade presente nesse tipo

\footnotetext{
${ }^{10}$ Conforme será visto no Capítulo 2, o termo concessão, para Zilberberg (2011a), refere-se à noção de "embora não fosse possível, tal coisa aconteceu", a qual se opõe à lógica implicativa, do "se... então".
} 
de relato. Pensamos que é graças a esse quantum emocional que tais notícias provocam grande interesse do enunciatário.

Entretanto, no Caso Isabella Nardoni, podemos elencar elementos que, hipoteticamente, possam responder às questões já apresentadas a respeito de sua duração, ou seja, o porquê de uma cobertura midiática tão extensa.

Em primeiro lugar, julgamos essencial a modalização do enunciatário "telespectador" pelo querer-saber, isto é, desconheciam-se as causas e os responsáveis pela morte de Isabella Nardoni. Em segundo lugar, posteriormente, o próprio pai e a madrasta da criança -dramatis personae, segundo a expressão de Barthes (1964, p. 197) - tornaram-se suspeitos pelo crime, o que por sua vez evidencia ainda mais as bases concessivas do caso.

É válido ressaltar que os protagonistas da história são brancos e de classe média, de modo a singularizar o relato, história que poderia ser considerada menos surpreendente se as circunstâncias fossem outras: pai e madrasta pobres e negros, por exemplo, tal como será objeto de análise no Capítulo 3, a propósito da notícia do bebê espancado até a morte. Ressalte-se ainda que o Caso Isabella Nardoni ocorreu em uma das regiões mais privilegiadas pela mídia brasileira ${ }^{11}$.

\footnotetext{
${ }^{11}$ Para Carvalho et al. (2010, p. 22-23), o Caso Isabella Nardoni obteve mais visibilidade que outros por uma questão, segundo os autores, "geográfica": "Além da importância jornalística [...], [o Caso Isabella Nardoni faz] parte de um pedaço do Brasil que concentra a maior parte de toda a riqueza produzida no país. Em São Paulo, Rio de Janeiro e Brasília, os fatos ganham uma dimensão maior que os que ocorrem em outros lugares porque estão perto das lentes das câmeras, das antenas dos links, do foco dos helicópteros, da aferição da audiência, do interesse das agências publicitárias e ao redor de uma estrutura que existe só em função desse arsenal de notícias, como assessorias de imprensa e autoridades acostumadas ao assédio dos jornalistas". Longe de querer empreender uma análise de cunho sociológico do caso aqui enfocado, a afirmação dos autores nos possibilita afirmar que certas práticas semióticas, elencadas na citação, são estabilizadas espacial e
} 
Além disso, havia bastante material fotográfico e audiovisual da vítima, sobejamente utilizado pelos meios de comunicação social: era uma menina bonita para os padrões hegemônicos. Não é demais ressaltar que o "bonito" se define semioticamente por relação ao "feio", e que signos do mundo natural são percebidos, semantizados e axiologizados pelo crivo cultural/ideológico. Assim, numa cultura como a nossa, em que a beleza branca é tradicionalmente eufórica em relação às belezas negra, indígena ou parda - estas, portanto, disfóricas (apesar de alguns avanços de natureza igualitária), podemos partir do pressuposto de que uma menina branca - e de classe média - assassinada cause maior impacto.

Por fim, estereótipos nos quais repousa o imaginário cultural ocidental são facilmente resgatáveis, por intertextualidade, remetendo, por exemplo, a histórias como "A Gata Borralheira” (lembre-se que Isabella era enteada de Anna Carolina Jatobá $\left.{ }^{2}\right)$.

Assim, conjecturamos que elementos do nível tensivo repercutem no da narrativa (modalizações e paixões) e do discurso (figuras e temas), sendo ele não apenas um "colorido" da ordem do contínuo sobre os demais

temporalmente no nível de pertinência das estratégias (Cf. FONTANILLE, 2008). Assim, o fator geográfico aludido pelos autores é semiotizável, a partir de uma noção mais ampla de texto, tal como nos propõe Landowski (1986). Este autor, ao semiotizar o contexto, levandoo para dentro do texto, através de uma "semiótica das situações", permite operacionalizar semioticamente o fato de que alguns episódios, por ocorrerem em determinadas partes do Brasil, sejam mais vistos/percebidos. Tensivamente, poder-se-ia, ainda, acrescentar que episódios como o Caso Isabella Nardoni repercutem mais porque estão num campo de presença privilegiado pela mídia.

${ }^{12}$ Motta (2008, s/p) chama atenção para um dado curioso da cobertura midiática do Caso Isabela Nardoni: o fato de a mídia sempre se referir à mulher de Alexandre Nardoni por "madrasta", conforme poderá ser visto na subseção analítica reservada às relações intertextuais que o Caso Isabella Nardoni permite estabelecer com contos de fada. 
patamares do sentido. Pelo contrário: o nível mais abstrato ecoa, faz-se sentir nos níveis mais complexos e concretos, como veremos no Capítulo 3.

Vamos verificar em nossa análise a presença de um enunciatário atento, curioso, ávido por saber. E se, portanto, há um enunciatário que quer-saber, o enunciador oferece informações de todos os tipos, formas e cores. Por fim, tal enunciador, com o intuito de fidelizar e aumentar a audiência, lança mão, ao lado desse fazer-saber e/ou fazer-crer, também de um fazer-sentir. É, assim, pela simbiose de tais elementos, entre o sensível e o inteligível, que pensamos ser conformado o enunciatário do fait divers.

\subsection{Justificativas}

\subsubsection{Justificativa geral}

Silverstone (2002), em Por que estudar a mídia?, refere-se a uma questão, da qual se depreende, por pressuposição, uma justificativa. Mais que isso, trata-se, a nosso ver, também de uma reafirmação, inclusive política, da necessidade de fazê-lo.

A indagação que intitula a obra, certamente, levanta questões pertinentes para uns - para esta pesquisa sobremaneira - mas, talvez, até despropositadas para outros. A posição destes últimos ancora-se, provavelmente, nos rastros de um pensamento de raízes frankfurtianas, o qual opõe, de forma privativa, a alta à baixa cultura (aí também incluída a cultura midiática), e que, invariavelmente, disforiza esta última. A partir de tal ponto de vista, os meios de comunicação e seus produtos são alienantes, 
de gosto duvidoso e popularescos. Tão somente o ópio do povo: o circenses, em complemento ao panem.

Cabe ressaltar a esse respeito, na esteira de Motta (2011), que Barthes, contemporâneo de Adorno, foi um dos primeiros teóricos a subverter a lógica de que apenas objetos caros à dita alta cultura eram dignos de serem estudados. A autora afirma:

À gravidade adorniana, Barthes contrapõe uma mordacidade sorridente. [Ele] se despoja de seus temas prestigiosos e não se envergonha em enfrentar a cultura das mídias, nem hesita, nesse passo, em ir às variedades, à publicidade, ao marketing (MOTTA, 2011, p. 164).

No que se refere à televisão, de acordo com Machado (2000, p. 16), o meio permanece ainda como o "mais desconhecido dos sistemas de expressão de nosso tempo". Esse desconhecimento se deve à ideia de que a televisão é um serviço, um sistema de difusão ligado às leis de mercado. Nesse sentido, segundo Barbeiro e Lima (2002, p. 15), as críticas mais duras feitas à televisão a entendem como "tecnologia de difusão de empreendimento mercadológico, sustentadora do regime econômico e máquina de moldar o imaginário". Observam também Mendes e Chrystus (2012, p. 81) que:

A partir da década de 1970, cruzaram-se duas perspectivas que deveriam, a priori, ser opostas: a dos intelectuais de esquerda e a dos proprietários de meios de comunicação. Entretanto, ambos os setores divulgavam um pensamento semelhante: a televisão encarada como meio popularesco, de mau gosto, grotesco e ideologicamente voltado para a manutenção do poder. 
De acordo com essa concepção, não interessaria o que se veicula na TV, mas os sistemas político, econômico e tecnológico que perpassam sua produção e recepção. Assim, por tais pontos de vista, prescinde-se do texto, o qual seria determinado unicamente em função do contexto (social, político, tecnológico, etc.).

Não ignoramos, entretanto, o constituinte ideológico dos meios de comunicação. Não desconhecemos ainda o fato de que as concessões públicas a empresas de comunicação no Brasil se concentram nas mãos de umas poucas famílias. A ideologia, como bem mostra Fiorin (2005a), é constitutiva da linguagem. Por isso, não desconsideramos a importância de estudos que destrinchem os mecanismos ideológicos da mídia (Cf. HERNANDES, 2006). Este autor, tendo participado de uma conferência de Fiorin, colheu a seguinte frase, que nos parece emblemática em relação a essa questão:

A compreensão crítica do discurso veiculado pelos meios de comunicação de massa é garantia do exercício pleno da cidadania $[\ldots]$. Por isso, é preciso compreender os mecanismos de que se vale o discurso para conseguir eficácia (2006, p. 13).

Pensamos, entretanto, que, ao lado de tal perspectiva, há espaço e pertinência para outras. Nossa questão por ora é: a mídia não é apenas ideologia, alienação, manipulação (na acepção mais pejorativa do termo ${ }^{13}$.

\footnotetext{
${ }^{13}$ Corrobora nosso pensamento Landowski $(2006$, p. 7), ao afirmar a respeito da mídia televisiva: "O que é a televisão? Um meio de informação? Uma droga (contra o tédio), um remédio (contra a solidão)? Um instrumento de socialização? Um aparelho ideológico? Uma forma de arte? Um simples suporte publicitário? Um pouco de tudo isso, certamente - mas não somente isso".
} 
Por isso, nossa abordagem se pretende menos crítica, no sentido de desvendar as astúcias manipulatórias dos meios de comunicação, e volta seu interesse para outro horizonte, outra faceta da mídia: interessa-nos aquilo que ela tem que nos afeta, que nos toca. Nesse sentido, Sodré (2006, p. 15) corrobora nossa preocupação com essa temática:

Profundamente imersos num processo civilizatório em que as imagens exercem um poder inédito sobre os corpos e os espíritos, começamos de fato a nos inquietar com o mistério da realidade sensível de que todos esses signos visíveis e sonoros $[\ldots]$ administram o afeto coletivo.

Para esse teórico da comunicação, a contemporaneidade pode ser definida como uma época estética, não pelo fato de haver uma relação direta com as artes, mas, fundamentalmente, porque seu campo estratégico é o do sentir, o da aisthesis. No âmbito da semiótica, a preocupação com a estesia evidencia-se sobretudo em Da imperfeição, em que o sentir, muito mais que a circulação de valores, é o foco de interesse de Greimas (2001). No que respeita a nosso trabalho, o sentir emana sobretudo da relação entre enunciador e enunciatário do fait divers, a qual, segundo Sodré (2009, p. 70), possibilita uma compreensão de fatos noticiosos mais perceptiva do que intelectiva.

Assim, partimos do pressuposto de que mídia é constituinte de nossas experiências. Por tal razão, ela configura sobretudo uma presença, ou seja, “o correlato perceptivo de uma grandeza puramente sensível" (FONTANILLE; ZILBERBERG, 2001, p. 135). A propósito da presença, em específico da televisiva, para Fechine (2008, p. 94), trata-se da maneira como o sujeito somática e sensorialmente sente. Segundo a autora (p. 87), 
Pode-se postular que, no limite, o próprio sentido que emerge deste tipo de situação se dá como um tipo de interação, com uma duração específica, entre sujeito e objeto num tempo e num lugar semióticos forjados para e pelo seu próprio encontro.

Dessa maneira, a mídia pode ser o ordinário e o contínuo onipresente em nossas vidas, ou, contrariamente, pode revelar-se como o abrupto, o surpreendente:

Ela está presente em todos os aspectos de nossa vida cotidiana. É impossível escapar à presença, à representação da mídia. Passamos a depender da mídia, tanto impressa quanto eletrônica, para fins de entretenimento e informação, de conforto e segurança, para ver algum sentido nas continuidades da experiência e também, de quando em quando, para as intensidades da experiência (SILVERSTONE, 2002, p. 9,12 ; itálicos nossos).

De modo semelhante, Ramos (2012, p. 9) destaca:

A Mídia impressa e eletrônica tem, na contemporaneidade, uma importância inestimável. Equipara-se e supera, pelo seu caráter massivo, em muitos casos, os significados do Estado e da Escola, sobretudo no Brasil. [...] É difícil afirmarmos, na atualidade, que alguém não possua algum nível de dependência da Mídia.

Para Silverstone (2002, p. 13), deve-se "estudá-la como algo que contribui para a capacidade de compreender o mundo, de produzir e partilhar seus significados”. Expõem ainda França e Corrêa (2012, p. 8) que o estudo da mídia mostra como mudanças sociais se dão a ver:

A força, a legitimidade e os arranhões sofridos por instituições clássicas como a justiça ou a família, por exemplo, encontram na mídia uma vitrine privilegiada - o 
que constitui uma razão a mais para considerá-la como objeto privilegiado de pesquisa.

Voltemos à especificidade da televisão no Brasil. De acordo com a Associação Brasileira de Rádio e Televisão, dados do censo do IBGE de 2011 mostram que $97 \%$ dos lares brasileiros possuem televisores ${ }^{14}$. Seria, assim, no mínimo, negligente ignorar a presença maciça da mídia televisiva - e de sua repercussão - na vida dos brasileiros. Aliado a esses dados, Travancas (2007, p. 58) ressalta o pouco ou quase nenhum hábito de leitura per capita da população brasileira, fato que, segundo a autora, contribui para o maior índice da presença e da importância da televisão no Brasil. Há mais de cinco décadas no País, o meio tornou-se um veículo profundamente popular, assim como a maioria dos programas por ele veiculados.

Por conseguinte, nesse cenário, tão marcado pela oralidade, o consumo de notícias dá-se primordialmente pelos telejornais. Ramos (2012, p. 130), na esteira de Canclini, afirma que " o telejornalismo tem um sentido muito particular para os brasileiros. Representa um Lugar de Referência, que se assemelha à importância da família, dos amigos, da escola, da religião e do consumo".

Apesar de todos esses argumentos, entretanto, poder-se-ia objetar que textos midiáticos são, por natureza, passageiros, fugazes, e que tal característica não justificaria uma empresa científica. Textos midiáticos são, sim, necessariamente, da ordem do transitório. Entretanto,

14 Disponível em: http://abert.org.br/site/index.php?/noticias/todas-noticias/ibge-divulgadados-estatisticos-de-radio-e-tv.html/ Acesso em: jul. 2012. 
[eles] são como todos os outros. Os meios para analisá-los e as perguntas que fazemos sobre eles não são essencialmente diferentes das indagações relativas a outros textos em outras épocas. O fato de eles serem, em algum sentido, populares ubíquos ou efêmeros não desqualifica esse tipo de investigação (SILVERSTONE, 2002, p. 61)

Posto isso, estudar a mídia, a nosso ver, não é uma escolha qualquer: analisá-la implica lançar luzes sobre os diversos patamares da organização de nossa cultura ${ }^{15}$. Por isso, a mídia, a cultura midiática, ao mesmo tempo, envolve, relaciona signos, textos-enunciados, objetos, práticas, estratégias e formas de vida (Cf. FONTANILLE, 2008).

Tomemos, por exemplo, o texto-enunciado, constituído de signos verbais e visuais, presente em quaisquer jornais impressos ou televisionados. Esse texto se apresenta num suporte, numa materialidade, enfim, num objeto: o jornal de papel pressupõe seu manuseio. O mesmo jornal lido num tablet, por exemplo, implica outro tipo de relação, de interação, entre leitor e texto, se comparada àquela do jornal físico. Pensemos, agora, nas práticas semióticas:

[As quais] (que se podem igualmente qualificar de sociais) apresentam-se como sequências significantes de comportamentos somáticos organizados, cujas realizações vão dos simples estereótipos sociais até programações de forma algorítmica. [...]. Nesse sentido, certas descrições de rituais e de cerimoniais são bastante concludentes (GREIMAS; COURTÉS, 2008, p. 380).

\footnotetext{
${ }^{15}$ Estudar o fait divers sobretudo na contemporaneidade implica, por extensão, estudar também aspectos que dizem respeito à mídia.
} 
Assim, ler diariamente os jornais, manuseá-los, sentir o toque de suas páginas, suas “propriedades sensíveis”, no dizer de Oliveira (2007, p. 79), constituem, dessa forma, uma prática semiótica. Também, pela manhã, conferir as principais notícias do dia nos sites da internet configura uma prática.

O nível das estratégias acomoda, num tempo e num espaço, o das práticas e, acima desses, encontra-se o das formas de vida, no qual estão cristalizadas as estratégias, obtidas por meio da repetição e da regularidade ${ }^{16}$. As formas de vida "permitem apreender a globalidade de uma prática significante ligada às escolhas axiológicas próprias a um indivíduo ou a uma cultura inteira" (FONTANILLE; ZILBERBERG, 2001, p. 225). Por esses níveis, vemos que a mídia permeia, constitui, sensível e inteligivelmente, a forma de vida do homem na contemporaneidade. São razões, enfim, contra as quais fica difícil se insurgir.

\subsubsection{Justificativa específica}

Feitas tais considerações de ordem geral, passemos à justificativa específica de por que estudar o fait divers.

\footnotetext{
${ }^{16}$ Portela (2008, p. 106) exemplifica o que chama de "de aspecto prospectivo ou preditivo da semiótica estratégica" no caso das narrativas audiovisuais ficcionais, nos quais "o problema da oscilação da audiência ocasionada por variações no enredo: a história de amor impossível, mas plausível, aumenta o interesse do público; as personagens de um núcleo de novela que não estão bem entrosadas na trama atraem pouco interesse. Nesse caso, valendo-se do pensamento estratégico, é possível conceber novas narrativas que explorem os motivos já consagrados pelos telespectadores ou, ainda, avaliar o risco assumido na criação de novos programas e formatos".
} 
Tal relato noticioso é marcado por um caráter inesperado, monstruoso, em geral do âmbito do privado, sempre ligado à lógica das paixões. Esse tipo de notícia, há séculos, suscita um interesse que permanece até os dias de hoje. Temas como morte, sexualidade e transgressões em geral rompem com tabus estabelecidos e têm no próprio relato um caráter eminentemente concessivo. Por tal razão, narrativas jornalísticas dessa natureza costumam despertar a atenção do enunciatário. Portanto, pensamos ser pertinente explicar discursivamente, pela ótica da tensividade, o interesse do enunciatário por tal categoria do jornalismo.

Além disso, conjecturamos ser profícuo aproximar os conceitos de fait divers e de acontecimento, não apenas pelo que ambos têm em comum, mas no sentido de forjar um modelo de maior poder heurístico para a sua abordagem, pois, sendo mais abstrato será, por conseguinte, mais econômico. A esse respeito, referimo-nos à ideia de concessão (ZILBERBERG, 2011a), tratada no Capítulo 2.

Cabe dizer também que, na atualidade, é relevante observar se a categoria jornalística em pauta é passível de acolher novas proposições. Não obstante a estrutura que lhe propôs Barthes (1964), pelo que procuramos demonstrar neste estudo, duração e memória são categorias que subjazem ao fait divers a partir de um ponto de vista gradativo.

E, por meio da abordagem tensiva do fait divers apresentada no Capítulo 4, visamos a oferecer uma possível contribuição à área, objetivo de qualquer trabalho que se pretenda científico, fato que também justifica esta empresa. 


\subsection{Objetivos}

\subsubsection{Objetivo geral}

O objetivo desta investigação é responder às questões já apresentadas, isto é, buscar nos mecanismos do discurso as estratégias usadas pelo enunciador "Jornal Nacional" para "extensivizar" a intensidade do fait divers Caso Isabella Nardoni, o qual se ancora numa estrutura acontecimental e que, por definição, deveria ser muito intensa mas pouco extensa ${ }^{17}$. Cabe esclarecer que a mídia, a nosso ver, não é responsável pela construção, em sentido estrito, do fenômeno Caso Isabella Nardoni, cujas peças, aos poucos, foram sendo montadas, independente do querer dos meios de comunicação. Por isso, quando nos reportamos às estratégias do enunciador para tornar mais extensa a intensidade de um acontecimento, não consideramos que os meios de comunicação "fabricam" o fenômeno - mas que o acontecimento midiático só existe enquanto tal duplamente mediado: pela linguagem e pelos meios de comunicação.

\subsubsection{Objetivo específico}

Quanto ao objetivo específico, procuramos semiotizar o conceito barthesiano de fait divers, estabelecendo, a partir das categorias analíticas da semiótica tensiva, outro enfoque para esse tipo de relato jornalístico. Se o Caso Isabella Nardoni teve uma cobertura duradoura, a maioria deles (por

\footnotetext{
${ }^{17}$ Embora se trate de um neologismo, o uso do termo "acontecimental" encontra respaldo nas mais de 25 mil ocorrências encontradas, em língua portuguesa, no maior site de buscas do mundo, o Google. Assim, faremos uso da expressão sempre que nos referirmos à forma adjetivada de "acontecimento".
} 
exemplo, a já citada reportagem de $O$ Globo), por seu turno, é relatada pela imprensa de forma pontual e não serial. Além disso, se a maior parte desse tipo de relato é esquecida rapidamente à medida que novos são apresentados, uma pequena minoria permanece na memória coletiva. Portanto, a partir de tais critérios, a semiótica tensiva oferece um aparato teórico-metodológico que dá sustentação a essa teorização sobre o fait divers proposta no Capítulo 4.

\section{DIVISÃO DA TESE}

Vejamos, em termos gerais, como se divide nossa investigação.

No primeiro capítulo, abordamos a categoria jornalística em que se insere nosso o desta pesquisa: o fait divers. Vamos às suas origens na França e, posteriormente, no Brasil. Analisamos as relações intrínsecas que esse tipo de relato possui com o folhetim, com o sensacionalismo e com o melodrama. Além disso, ressaltamos o fascínio despertado por notícias dessa natureza, na esteira de autores como Morin, Merleau-Ponty e Foucault. O capítulo ainda apresenta o texto mais célebre sobre o tema ("Structure du fait divers"), no qual Roland Barthes lhe estabelece uma estrutura ${ }^{18}$. A partir de Barthes (1964), relacionamos tal conceito ao conceito de acontecimento (ZILBERBERG, 2007, 2011a). Esboça-se, então, o que chamamos de "uma abordagem tensiva do fait divers".

\footnotetext{
${ }^{18}$ Utilizamos o texto original francês, salvo nos casos em que a tradução de Leyla PerroneMoisés ("Estrutura da notícia"), publicado em Crítica e verdade ou a de António Massano e Isabel Pascoal ("Estrutura do caso do dia"), publicado em Ensaios críticos, ajudou-nos a esclarecer alguma passagem.
} 
No segundo capítulo, expomos os principais elementos da gramática tensiva, teoria que privilegia a noção de continuum e da afetividade do discurso, a partir do ponto de vista da complexidade; afinal, qualquer valor equivale à correlação de uma valência intensiva e uma valência extensiva e é, por isso, complexo. Neste capítulo, ainda, abordamos a preocupação dos atuais estudos semióticos com a questão do "vivenciado" - a partir de uma inspiração fenomenológica -, entretanto, sem abandonar as bases linguísticas que dão suporte à disciplina desde seus primórdios. Tendo apresentado as premissas gerais, partimos para a exposição dos conceitos basilares da teoria. Tratamos, ainda, dos dois estilos discursivos que a gramática tensiva prevê: o acontecimento e o exercício. Detemo-nos, finalmente, na relação entre jornalismo e acontecimento, a qual, por sua vez, diz tanto sobre a natureza do corpus quanto, sobretudo, da engrenagem do discurso jornalístico.

Amparados nessa base conceitual, analisamos o corpus no Capítulo 3. Inicialmente, detemo-nos na cobertura realizada pelo Jornal Nacional sobre o Caso Isabella Nardoni e enfocamos, pelo viés da tensividade, os seguintes eixos de análise: concessão e fidúcia, duração e intensidade, a paixão da comoção e, por fim, relações intertextuais e interdiscursivas que o texto em análise permite estabelecer com outros. Em seguida, empreendemos uma leitura semiótica de outros faits divers com o fito de observar as (in)variantes que subjazem a esse relato jornalístico.

No quarto capítulo, com base na teoria exposta e nas análises realizadas, apresentamos alguns elementos que dão suporte à nossa proposta de abordagem tensiva do fait divers, cujo caráter heurístico traduz-se por flagrar sobretudo a natureza contínua e afetiva desse texto jornalístico, uma 
arte das massas, no dizer de Barthes (1964, p. 203), que cumpre o papel de "preservar no seio da sociedade contemporânea a ambiguidade do racional e do irracional, do inteligível e do insondável" (itálicos nossos). Pela metalinguagem semiótica, a ambiguidade desse relato noticioso remete, a nosso ver, à correlação entre extensidade e intensidade, complexidade essa que define o ponto de vista tensivo. 
$\left[C_{0}^{1}\right.$

"En un mot, ce serait une information monstrueuse."

Roland Barthes 


\section{ORIGENS DO FAIT DIVERS}

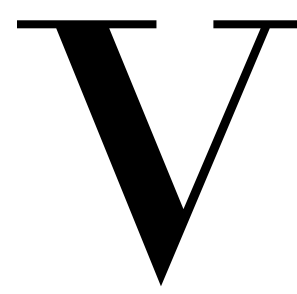

erificou-se, pela primeira vez, o uso do termo fait divers no periódico parisiense Le Petit Journal, de Moïse Polydore Millaud, cujo primeiro número foi publicado em $1^{\circ}$ de fevereiro de 1863. A expressão, desde então, é largamente utilizada. Meyer (1996, p. 98) com base no prefácio do catálogo de uma exposição sobre o tema, organizada pelo Musée National des Arts et Traditions Populaires de Paris em 1982, relata que:

O termo fait divers tornou-se hoje de uso tão banal que nem nos ocorreria interrogar-nos sobre a realidade do que ele recobre. É utilizado todos os dias como se designasse um conceito bem definido que nos viria naturalmente ao espírito. Trata-se de expressão relativamente recente. Surgiu em Le Petit Journal em 1863 e não consta que tivesse sido utilizada anteriormente. Até então, falava-se, como diziam Balzac ou Nerval, de "canards" ou de "faits Paris", ou de "nouvelles" que são qualificadas de "curiosas", "singulares", ou de "extraordinárias". Deve-se notar também que a maioria das línguas europeias não dispõe de um equivalente exato. [...] A expressão fait divers não designa somente uma atividade de distribuição das notícias entre as rubricas de um jornal, ou um tipo de informação, mas também, com uma conotação explicitamente pejorativa, uma categoria particular de acontecimentos.

Embora o termo remonte ao advento da imprensa de massa, na segunda metade do século XIX, segundo Dion (2007, p. 127), esse tipo de notícias existia muito antes de sua veiculação nos jornais. Suas narrativas estavam relacionadas a um tipo de espetáculo cultural, em que o público participava e cuja transmissão era eminentemente oral. Nesse sentido, Ramos (2008, p. 137) mostra que o fait divers "já existia em diferentes 
produções culturais, na Idade Média, habitando os cantos dos menestréis, em seus apelos e interpelações de entretenimento”.

Foi, entretanto, nos "ocasionais" (Cf. DION, 2007, p. 127), publicações de caráter não periódico, conforme o próprio nome indica, que o fait divers passou à sua forma escrita. Nessas publicações, constavam acontecimentos políticos da época, tais como as guerras na Itália, episódios da realeza, além de notícias extraordinárias e curiosas. Segundo a autora, esse tipo de folheto era vendido tanto em grandes centros quanto no interior da França. Contudo, as notícias impressas "difundidas no meio popular permanecem fortemente marcadas pela oralidade. Seu consumo não é individual, mas coletivo e serve geralmente para um verdadeiro espetáculo" (p. 127).

De natureza periódica, surgem, no século XVIII, as gazetas, publicações destinadas à elite. A imprensa popular, por sua vez, constituiuse, além dos "ocasionais", dos canards, “jornais populares de apenas uma página, impressos na parte frontal e que comportavam título, ilustração e texto" (ANGRIMANI, 1995, p. 19).

Narrativas minuciosamente descritas eram recitadas pelos canardiers, que vendiam esse tipo de folheto ilustrado ao final de suas apresentações. Para Foucault (1977, p. 218), “os panfletos [canards], no início do século XIX, compunham-se, em geral, de duas partes. Uma era a narrativa 'objetiva' dos acontecimentos, feita por uma voz anônima; a outra era a cantiga de lamento feita pelo criminoso". Angrimani (1995, p. 19-20) afirma ainda que:

Os canards mais procurados eram os que relatavam faits divers criminais: crianças martirizadas ou violadas, parricídios, cadáveres cortados em pedaços, queimados, enterrados. Assim como eclipses, cometas, grandes 
catástrofes, tremores de terra, inundações, desastres de trem, naufrágios. Os vendedores de canards saíam às ruas aos gritos, chamando a atenção do público para suas manchetes. [...] Além de "pato", o termo canard significa também conto absurdo, fato não verídico, cambalacho e, posteriormente, folhetim ilustrado.

Em meados do século XIX, a imprensa tornou-se acessível a todo tipo de público, o que não era o caso, por exemplo, das gazetas. Nasce, assim, a “imprensa popular a um tostão" (DION, 2007, p. 128), publicações compostas essencialmente de notícias inusitadas. Segundo a autora, esses jornais rapidamente se disseminaram e mudaram a forma da comunicação dos faits divers, até então, coletiva e oralizada.

\subsection{FAIT DIVERS NO BRASIL}

No Brasil, relatos de mortes, suicídios e desgraças em geral chegam "quase ao mesmo tempo em que se difundem pela Europa e encontram aqui pronta acolhida" (GUIMAR ̃̂ES, 2006) ${ }^{19}$. A partir do século XX, o fait divers torna-se cada vez mais presente nas páginas dos jornais brasileiros. Em 8 de dezembro de 1910, por exemplo, podia-se ler nas páginas de $O$ Estado de $S$. Paulo a notícia intitulada "Os desesperados", cujo subtítulo era: "Uma rapariga que tenta suicidar-se, ingerindo querosene e alvaiade". Reproduzida de Guimarães (2006), segue a notícia:

Maria dos Santos é o nome de uma rapariga de cor preta, que reside à rua Joaquim Nabuco, 18. Maria há muito enamorara-se perdidamente de um caboclo espadaúdo, possuidor de fortes bigodes e cabeleira encaracolada. João -

\footnotetext{
${ }^{19}$ Os trechos citados de Guimarães (2006) não possuem, no original, indicação de página.
} 
assim se chama ele - correspondeu durante alguns meses à afeição que lhe dedicava a rapariga e, diariamente, ia visitála, acompanhando-a a diversos cinemas no bairro do Brás. Estavam as coisas neste pé, quando João conheceu outra rapariga, a quem principiou a cortejar. Maria soube do caso e enfureceu-se, fazendo-lhe ver o seu procedimento incorreto, enganando as duas mulheres ao mesmo tempo. João, que já se havia aborrecido dela, achou magnífico o pretexto para acabar com aquilo, e assim o fez. A infeliz Maria, desesperada com o procedimento do seu namorado, ficou muito triste e escreveu-lhe diversas cartas chamando-o, suplicando-lhe que não fosse tão ingrato, que tivesse pena dela, e que se não atendesse a seus rogos, matar-se-ia. João, seriamente preocupado com sua nova apaixonada, não ligou importância ao caso. Maria esperou debalde alguns dias e, vendo que ele não mais a queria, resolveu pôr em prática o que prometera. Assim é, que ontem à tarde, recolheu-se a seu quarto e encheu um copo de querosene. Em seguida, adicionou-lhe uma boa porção de alvaiade em pó, ingerindo tudo de um trago. Momentos depois principiou a gritar desesperadamente, alarmando os vizinhos, que correram a comunicar o que se passara à polícia do Brás, comparecendo ao local o capitão Ancede, primeiro subdelegado, acompanhado do sr. dr. Marcondes Machado que fez os primeiros curativos. Maria, cujo estado foi considerado grave, ficou em tratamento em sua casa.

Segundo a autora, na seção "Notícias Diversas" de O Estado de S. Paulo, encontravam-se ainda manchetes como estas: "Mordido por um cão", "Drama de Sangue", "Tentativa de Suicídio", "Queda e ferimento", "Amor Funesto", "Desastre", etc. O fait divers, portanto, desde a popularização da imprensa no Brasil, no início do século XX, tem lugar cativo nos periódicos.

Se nos centros mais populosos do Brasil, no início do século XX, o consumo do fait divers tinha como veículo os jornais, a Região Nordeste, por sua vez, deu origem a um gênero de poesia muito semelhante ao canard francês: a literatura de cordel. Segundo dados da Fundação Casa de Rui Barbosa, obtidos em pesquisa de S. Mendes (2011, p. 34), os primeiros 
folhetos de literatura de cordel datam do início do século XX. O panfleto que, em geral, constitui-se de oito páginas, medindo cerca de 11x16cm, traz, com frequência, ilustrações de xilografia na capa. Os cordéis têm temas recorrentes, semelhantes aos do fait divers. Segundo a autora, as estratégias de captação do leitor de literatura de cordel ancoram-se na dramatização: "Ao falar do assassinato de uma pessoa, por exemplo, o cordelista costuma descrever as reações afetivas ao fato, como a comoção, a tristeza e a indignação" (MENDES, 2011, p. 32).

Outro ponto importante da história do fait divers no Brasil remonta ao ano de 1963, quando surge o Notícias Populares (NP), em São Paulo, cujo enfoque quase que exclusivo eram tais relatos noticiosos. Segundo Angrimani (1995, p. 97), o jornal pautava-se pelo tripé "sexo-crimeescândalo", além das reportagens inventadas, tal como o conhecido caso do bebê-diabo ${ }^{20}$. Caracterizava-se por um estilo popularesco, com manchetes em tipografia exagerada, imagens coloridas de cadáveres, nudez e linguajar chulo:

"Quis Pipa e Levou Nabo" [é a manchete] sobre um menino de 10 anos, que perdeu um papagaio (pipa) e acreditou na conversa de um homem que lhe disse que lhe arrumaria um novo. O menino foi, na realidade, sequestrado, levado para um apartamento e estuprado. [...] "Maradona Bom de Bola e Ruim de Taco" mostrava o jogador de futebol Diego Maradona nu. (ANGRIMANI, 1995, p. 88).

\footnotetext{
${ }^{20}$ Angrimani (1995, p. 139) afirma que o NP "ostenta a fama de ser o jornal que perpetrou a maior 'cascata' [mentira] da história da imprensa brasileira". A história fictícia do bebêdiabo ocupou as páginas do Notícias Populares por 22 edições.
} 
Discini $(2009$, p. 125) assim descreve a primeira página de uma edição desse periódico:

O Notícias Populares [...] apresenta título de maneira anárquica, fora do cabeçalho, no centro da página, com letras menores do que aquelas da manchete principal. [...] Em NP, ainda, no lugar do cabeçalho, no primeiro espaço da leitura, está, em destaque, o preço, 70 centavos.

Para Angrimani (1995, p. 98), o Notícias Populares assemelhava-se aos canards franceses tanto pela tiragem reduzida, cerca de 80 mil exemplares, quanto pela centralização no fait divers. Havia, inclusive, manchetes semelhantes: "Uma mulher queimada viva por seus filhos" era a chamada de um canard, enquanto no Notícias Populares podia-se ler: "Homem nu assado na fogueira". Segundo o autor (p. 98), "se os canards falavam em 'homempeixe', 'monstros', 'dragões', 'bestas', o Notícias Populares [reportava] sucuris gigantes devoradoras de pescadores, saúvas comedoras de crianças e vampiros".

Discini (2009, p. 137) também associa o estilo do Notícias Populares ao fait divers quando afirma:

Esse estilo de imprensa [...] corresponde [...] aos faits divers da imprensa francesa, pontilha-se de malícia para refletir a cotidianeidade de cada leitor, refratando-a pela fixação de eventos extravagantes e trágicos da vida privada.

Segundo a autora (2009, p. 37), quanto mais hiperbólicas fossem as manchetes e as fotos, tanto no plano do conteúdo quanto no plano da expressão, mais impactante era a enunciação desse periódico, cujo objetivo era "o grito, o susto, o baque de um tiro de revólver". 
O Notícias Populares circulou até 2001. Em sua última edição, em 20 de janeiro daquele ano, estampava a primeira página o seguinte trecho, como informa Discini (2009, p. 151):

Lançado em 15 de outubro de 1963, O Notícias Populares viveu muitas glórias em seus 37 anos de vida. Foi marca registrada do jornalismo popular brasileiro. Revolucionou com assuntos polêmicos, textos curtos, uso de gírias, títulos e fotos grandes. O sucesso dessa fórmula de jornalismo foi parcialmente copiado e transferido para a TV, em telejornais como o 'Aqui Agora', e até em programas de auditório com grande audiência, como os do Ratinho, Gugu e Faustão.

O Aqui Agora, exibido pelo Sistema Brasileiro de Televisão (SBT), entre 1991 e 1997, tinha Gil Gomes como o repórter de maior destaque, conhecido pelos gestos e pela voz impostada e grave, que se tornaram sua marca registrada. Segundo $\operatorname{Ramos}(2012$, p. 112), "[tal] noticiário tinha uma predileção. Eram os dramas e as tragédias de cunho policial [...]. A diversidade se estabelecia como unidade, através do fait divers". O autor mostra que, em 7 de julho de 1993, o programa levou ao ar um suicídio ao vivo: "A recepcionista, Daniele Alves Lopes, de 16 anos, se jogou do sétimo andar de um prédio no centro de São Paulo, com uma altura aproximada de 40 m” (RAMOS, 2012, p. 113).

Atualmente, pelo menos dois programas de TV aberta de difusão nacional, semelhantes ao extinto Aqui Agora, são exibidos todos os dias: o Cidade Alerta, na Rede Record, apresentado pelo jornalista Marcelo Rezende, e o Brasil Urgente, na Rede Bandeirantes, comandado pelo também jornalista José Luiz Datena. Nota-se, assim, que o interesse do público pela temática do fait divers, até os dias de hoje, motiva a exibição de programas de TV e 
circulação de periódicos populares ${ }^{21}$. Nesses veículos, um ingrediente, tal como no Notícias Populares e, ainda, nos canards franceses é, notadamente, o fait divers. Assim, como salienta Amaral (2011, p. 76): "Do melodrama e do folhetim, o jornalismo popular herda esse envolvimento com o público, a pressão dos leitores e o enraizamento na vida cotidiana".

\subsection{FAIT DIVERS E SENSACIONALISMO}

O fait divers é considerado sinônimo, muitas vezes, de "informação sensacionalista" (RAMOS, 2008, p. 137; RAMOS, 2012, p. 18, 24), fato compreensível, considerando-se a derivação da palavra: sensação, sensacional, sensacionalismo. Segundo Landowski (1992, p. 124), na imprensa sensacionalista, "se cultiva o puro estado de alma, em que o 'cotidiano', vivido apenas no modo passional (medo, ódio ou desejo), nada mais é que pretexto para a exaltação das subjetividades". Não há dúvidas, o fait divers ancora-se num substrato patêmico, sensorial, estésico. Entretanto, na esteira de Angrimani (1995, p. 16), pensamos que o sensacionalismo difere-se do fait divers em alguns aspectos:

\footnotetext{
${ }^{21}$ De acordo com a Associação Nacional de Jornais, em pesquisa relativa a 2011, num ranking dos 10 maiores jornais em circulação diária e paga no Brasil, seis são populares. $\mathrm{O}$ de maior tiragem é o mineiro Super Notícia, cuja média de circulação é de 293.572 exemplares por dia, superando o tradicional Folha de S. Paulo, com média diária de circulação de 286.398 exemplares. Os demais periódicos populares presentes nesse rol são: Extra (RJ); Daqui (GO); Diário Gaúcho (RS); Correio do Povo (RS) e Meia Hora (RJ). Disponível em: http://www.anj.org.br/a-industria-jornalistica/jornais-no-brasil/maioresjornais-do-brasil/. Acesso em: jul. 2012.
} 
Sensacionalismo é tornar sensacional um fato jornalístico que, em outras circunstâncias editorais, não mereceria esse tratamento. Como o adjetivo indica, trata-se de sensacionalizar aquilo que não é necessariamente sensacional, utilizando-se para isso de um tom escandaloso, espalhafatoso.

Além disso, o veículo sensacionalista distingue-se do não sensacionalista pela pouca ou nenhuma credibilidade e, estilisticamente, pelo uso de uma linguagem excessivamente coloquial, que comporta gírias e expressões vulgares, pela inadequação entre manchete e texto, pela tipografia exagerada ou volume de voz excessivo e pela iconografia de caráter mórbido e sexual. Desse modo, o ethos da imprensa dita sensacionalista, para Discini (2009, p. 40), "grita, porque [é] hiperbólico [e] se corporifica por ocupar de maneira própria um espaço social, [opondo-se] a um ethos eufemístico e que fala baixo, dos jornais da imprensa dita séria”.

Ressalta-se ainda que, embora o fait divers seja um elemento imprescindível para o veículo sensacionalista, ele não é o único: a vida das celebridades é fortemente explorada por esse tipo de veículo. O programa TV Fama, da Rede TV, por exemplo, pauta-se unicamente pela vida dos “olimpianos", nos termos de Morin (2011). É sensacionalista, sem, no entanto, beber da fonte do "monstruoso".

Em suma, os veículos sensacionalistas "carregam nas tintas", intensificam a carga emocional do relato, configurando sobretudo um estilo ${ }^{22}$.

\footnotetext{
${ }^{22}$ Pelo fato de os estudos sobre estilo/estilística reunirem trabalhos das mais diversas orientações e tendências, que se encontram sob a rubrica desse termo, faz-se necessário enunciar o que entendemos por estilo. Fazemo-lo, a partir da perspectiva de Discini (2009), segundo a qual, "o estilo é um conjunto de características da expressão e do conteúdo que criam um ethos. [...] Pensamos no estilo como o modo próprio de dizer de uma enunciação única, depreensível de uma totalidade enunciada. Essa perspectiva faz com que as relações
} 
Sobre o estilo do Notícias Populares, que metonimicamente pode ser tomado como o de toda a imprensa dita sensacionalista, Discini (2009, p. 150) observa:

Do modo de dizer de NP, respaldado, por exemplo, pela anarquia diagramática, o leitor constrói, portanto, um estado emocional acelerado, de exaltação passageira, de presença pouco comovida frente a entranhas sangrentas, "dilaceradamente" expostas. Pela recorrência dos volteios discursivos observados, anestesiam-se enunciador e enunciatário, de maneira que aquele pode parecer brincar, e este também. Aquele desenvolve um falar tido como "à margem" da norma culta, este também. Aquele parece desprezar a reflexão, a crítica, que antecedem a participação política, inerente à cidadania, este também. Assim é construído, dia após dia, o corpo de um ator da enunciação de uma totalidade de discursos. Assim se define o estilo de NP.

Entretanto, cumpre dizer que, mesmo na imprensa dita séria - que só existe em oposição com a imprensa dita sensacionalista, como bem salienta Discini $(2009$, p. 117) - , o fait divers possui lugar instituído, tanto o é que o corpus desta tese constitui-se, majoritariamente, de uma série de reportagens sobre um fait divers no telejornal de maior importância no Brasil ${ }^{23}$.

de sentido convirjam recorrentemente para um centro que, longe de mostrar um sujeito empírico, cria o próprio sujeito" (p. 7, 17).

${ }^{23}$ Segundo Bucci (2007),"pode-se dizer que ele [o Jornal Nacional] é a instituição jornalística central no Brasil de hoje". 


\subsection{FAIT DIVERS E FOLHETIM}

É necessário também destacar a relação entre o fait divers e o folhetim, “irmãos xifópagos”, na compreensão de Meyer (1996, p. 224). O termo feuilleton, no início do século XIX, remetia apenas a um espaço geográfico preciso nas páginas do jornal: o rodapé, em geral na primeira página, cuja finalidade era, especialmente, o entretenimento:

Aquele espaço vale-tudo suscita todas as formas e modalidades de diversão escrita: nele se contam piadas, se fala de crimes e de monstros, se propõem charadas, se oferecem receitas de cozinha ou beleza; aberto às novidades, nele se criticam as últimas peças, os livros recém-saídos - o esboço do Caderno B, em suma (MEYER, 1996, p. 57-58).

De termo genérico, o feuilleton passa a designar "ficção em fatias" no jornal diário: o romance-folhetim. Segundo a autora (p. 59), esse tipo de ficção seriada surgiu das próprias necessidades dos jornais, independente da filiação política de tais publicações. Assim, quando um folhetim agradava, podia provocar um acentuado aumento no número de assinaturas. A partir da década de 1840, toda a ficção em prosa passa a ser publicada em forma de folhetim: "Não se trata mais para o romance-folhetim de trazer para o jornal o prestígio da ficção em troca da força de penetração deste, mas pelo contrário, é o romance que vai devorar seu veículo” (MEYER, 1996, p. 61).

Para Morin (2011, p. 50-51), o imaginário popular se modifica com o advento do folhetim de imprensa no século XIX, e duas correntes de leitores vão se formar: uma popular e uma burguesa, ambas, no entanto, ávidas leitoras do gênero:

A corrente popular pega personagens da vida quotidiana, mas esses personagens estão empenhados em aventuras 
"rocambolescas", em que, às vezes, até o fantástico irrompe [...]. Diversamente da corrente burguesa (que vai em direção do psicologismo, dos conflitos de sentimentos e de caracteres, dramas ou comédias triangulares do esposo, do amante e da mulher adúltera), a corrente popular permanece fiel aos temas melodramáticos.

Morin (2011, p. 93) fala ainda da "vedetização" dos faits divers: "[os quais] não são acontecimentos que informam o andamento do mundo; são, em comparação com a História, atos gratuitos. Mas esses atos afirmam a presença da paixão, da morte e do destino". Por isso, folhetim e fait divers apresentam uma estreita relação como expõe Meyer (1996, p. 79, 100):

O "acaso" do folhetim tem muito a ver com a fatalidade estúpida, o imprevisível do cotidiano: o menino que, entre tantos lugares, vai escolher para brincar o lugar impossível e real poço artesiano que o traga, criando o insuportável suspense de um desejo concentrado na impossível salvação. Reencontramos aqui o universo do folhetim e a sua relação de causalidade muitas vezes estrambótica, sua estrutura iterativa que não é só chamariz para segurar o público, mas uma cadeia de coincidências que também tem significado, subentendendo a noção de Providência [típica do fait divers] $[\ldots]$ o folhetim que parece o melhor exemplo de obra aberta a todos os caprichos do leitor $[\ldots]$, parece $[\ldots]$ se aproximar $[\ldots]$ do fait divers; sua repetição estrutural acaba sendo produtora de um sentido misterioso que no entanto sempre escapa, nunca se alcança, e é precisamente o grude que mantém preso o leitor, que "sabe" perceber as "coincidências" habilmente montadas pelo autor-Providência. Outros pontos em comum são o patético das situações, o gosto pelo excesso melodramático, os contrastes.

Assim, o caráter inesperado e, ao mesmo tempo, reiterativo tematicamente do fait divers, transmitido de forma romanceada, melodramática, faz com que esses dois tipos de relato tenham muitos pontos de interseção. Em suma: 
O folhetim ficcional inventando fatias de vida servidas em fatias de jornal, ou os faits divers dramatizados e narrados como ficção, ilustrados ambos com essas gravuras de grande impacto, ofereciam às classes populares o que desde os tempos da oralidade e das folhas volantes [canards] as deleitava: mortes, desgraças, catástrofes, sofrimentos e notícias - tais como nossos folhetos de época nordestinos as continuam narrando - reatualizados nos termos da modernidade industrial e urbana. Ou seja, como diz Walter Benjamin, "injetar o veneno da sensação à experiência vivida, quase por via endovenosa" (MEYER, 1996, p. 224).

Cabe ainda frisar algumas diferenças entre o romance-folhetim e o fait divers. A primeira delas é a serialidade, elemento do qual este, preliminarmente, não se constituiria ${ }^{24}$. A segunda diferença, aparentemente ingênua, é que o folhetim se refere a um relato ficcional, enquanto o fait divers, a um relato do "real", embora, em certos momentos, essa fronteira não se apresente muito nítida ${ }^{25}$.

Semioticamente, o real se refere antes a uma construção discursiva que a uma ontologia, ao real propriamente dito ${ }^{26}$. Tanto o é que, na

\footnotetext{
${ }^{24}$ Embora, como poderá ser visto no Capítulo 4, a duração é uma categoria que subjaz ao fait divers, por meio de uma perspectiva gradiente: do menos durativo ao mais durativo.

${ }^{25}$ Para Meyer (1996), o fait divers se trata de uma notícia romanceada e há casos, segundo Angrimani (1995), de faits divers inventados, tal como o já citado caso do bebê-diabo.

${ }^{26}$ No que se refere a uma distinção entre o "real" e o ficcional pela perspectiva da semiótica, cabe salientar que essa diferença resolver-se-ia em termos modais, pois, passa, necessariamente, pelo crer do enunciatário. Conforme salienta M. B. T. Mendes (2008, p. 273): "Em cada ato de comunicação, sempre haverá um fazer persuasivo do enunciador, garantindo a 'veridicção' do discurso, e um fazer interpretativo do enunciatário, garantindo, ou não, sua 'fidúcia'. Nesse processo manipulatório, acreditamos que o gênero discursivo/textual desempenha uma importância-chave para a adesão do enunciatário ao relato "real" ou ficcional midiatizado. O enunciador, ao açambarcar as características constitutivas de cada gênero discursivo - temática, forma composicional e estilo (BAKHTIN, 2003, p. 261) cria, por sua vez, dois tipos de contratos fiduciários: no caso da narrativa ficcional, a crença do enunciatário baseia-se na relação entre parecer vs. não-ser; no caso da narrativa jornalística, por sua vez, na relação entre parecer vs. ser.
} 
introdução de seus Caminhos da semiótica literária, Bertrand (2003, p. 11) não tarda a ressalvar que a semiótica se interessa pelo "parecer do sentido". Noutros termos, o "real", para a semiótica, é tratado como veridicção, um dizer-verdadeiro construído como tal no e pelo texto/discurso. A alta densidade sêmica, como substrato da verossimilhança, tem função capital no que se refere a esse parecer-verdadeiro, cujo objetivo é notadamente a persuasão (GREIMAS; COURTÉS, 2008, p. 534). Tal efeito produz-se por meio de operações de figurativização, que vão do mais abstrato ao mais icônico: "Iconização e abstração [...] constituem antes graus variáveis da figuratividade" (GREIMAS, 2004, p. 81). A iconicidade ocorrerá se o formante figurativo for pertinente, isto é, quando reunir um número mínimo de traços, de modo a constituir uma certa densidade sêmica, "[necessária] e suficiente para permitir sua interpretação como representante de um objeto do mundo natural" (2004, p. 81). Por isso, pela figuratividade, é construído um efeito de realidade nos textos.

Pela perspectiva semiológica de Barthes (2012, p. 181-190), tratar-se-ia do que o autor chama de "efeito de real", um significado de conotação advindo das descrições, dos "pormenores ‘supérfluos”" (p. 181):

O barômetro de Flaubert, a pequena porta de Michelet afinal não dizem mais do que o seguinte: somos o real [cujo efeito é] o fundamento dessa verossimilhança inconfessável de todas as obras correntes da modernidade (p. 190). 
Assim, a partir de uma "epistemologia discursiva" (BEIVIDAS, 2008), folhetim e fait divers mais se aproximam do que se distinguem ${ }^{27}$. Por fim, uma consideração de ordem semântico-etimológica: nouvelle, em francês, refere-se tanto a "notícia" quanto a "novela", fato que corrobora as similitudes entre tais tipos de relato no que tange ao caráter verossimilhante e veridictório de ambos.

\subsection{O MELODRAMA}

Antes de avançar pela trilha do fait divers, entretanto, é necessário fazer uma pequena parada no universo do melodrama. Se há poucos parágrafos dissemos que tanto ele quanto o folhetim pautam-se pelo melodrama, cumpre escrutinar esses laços comuns.

O termo melodrama origina-se na Itália do século XVII e designa, inicialmente, um drama teatral inteiramente cantado. Segundo Huppes (2000, p. 21), sua origem está associada à ópera, mas também à opereta e à ópera popular. Quando chega à França, o melodrama passa a classificar peças que faziam uso da música, mas que escapavam aos cânones do teatro clássico. No século XIX, o gênero romanesco passa a servir ao melodrama como uma "reserva inesgotável de intrigas e peripécias" (THOMASSEAU, 2005, p. 26). O melodrama, então, torna-se "uma espécie de denominador

\footnotetext{
${ }^{27} \mathrm{O}$ autor propõe um terceiro paradigma a coexistir com o paradigma científico e com o filosófico: o paradigma discursivo, segundo o qual, "a verdade" possível das coisas não está nas coisas do mundo nelas mesmas, nem na razão do sujeito, mas antes na linguagem, que dá forma, sentido, ao mundo e à razão.
} 
comum do estilo teatral romântico" e também sucessor da tragédia "que a civilização emergente ensejou produzir" (HUPPES, 2000, p. 10).

O primeiro melodrama que fixou as invariantes do gênero foi Coelina ou l'Enfant du mystère, de 1800, escrito por René Charles Guilbert Pierre de Pixérécourt. A peça ficou em cartaz durante muitos meses em Paris e nas províncias do interior da França. Thomasseau (2005, p. 23-24) assim resume o início dessa história cheia de reviravoltas e segredos desvendados:

Dufour, honesto burguês, acolheu em sua casa sua sobrinha Coelina, cuja fortuna ele administra, também honestamente. Por delicadeza, ele hesita em dar a mão da jovem a seu filho Stéphany, apesar do amor que ambos sentem um pelo outro. Dufour dá também comida e abrigo para um pobre mudo, Francisque Humbert, doente, devido a agressões sofridas. O pobre homem desperta a compaixão de Coelina, que vela por ele com ternura. Os escrúpulos de Dufour a propósito da herança de Coelina levam-no a aceitar o pedido de sua mão por um certo Truguelin. Quando Truguelin visita Dufour, ele encontra e reconhece Humbert que, por seu turno, treme à visão do visitante, no qual ele identifica um de seus antigos agressores. Para evitar ser desmascarado, Truguelin trama com Germain, alma perversa que é seu criado, a morte de F. Humbert.

A partir desse fragmento, podem-se imaginar as idas e vindas, os embates entre o bem e o mal, estes, segundo Braga e Penjon (2005, p. 6-7), constantes nos melodramas.

Tal narrativa teatral visa, ao mesmo tempo, ao universal e ao cotidiano, procurando, fundamentalmente, comover o público: "Por excelência moderno, o melodrama busca deliberadamente a sintonia com o grande público, identificando nessa adesão caminho para o sucesso" (HUPPES, 2000 , p. 23). No entanto, engana-se quem pense que os melodramas têm 
sempre um final feliz: "Se o objetivo é garantir fortes emoções para o público, um desfecho negativo revela amiúde eficácia bem superior" (HUPPES, 2000, p. 38). Todavia, mostra Thomasseau (2005, p. 36) que ocorre, em geral, o desmascaramento do vilão pelo herói, de cuja estrutura se depreende uma axiologia moralizante. Assim, no final da história, os valores eufóricos são sancionados positivamente, e os disfóricos, negativamente.

Os temas do melodrama são, em geral, substituição de crianças, semelhanças fortuitas ou premeditadas, usurpações de qualidades ou de títulos, cartas extraviadas, perdidas, reencontradas, encontros desmarcados, falsos endereços. Esses enganos, reconhecidos no final da história, são, na verdade, a mola mestra dessas tramas, e é nisso que se fixa o interesse do público: "Esta obsessiva bipolaridade temática da perseguição e do reconhecimento não prejudica em nada o gênero, pelo contrário, é ela que dá ao melodrama sua dinâmica própria” (THOMASSEAU, 2005, p. 37). Huppes (2000, p. 33), por sua vez, reduz para dois os temas fundamentais do melodrama: a reparação da injustiça e a busca da realização amorosa, temas recorrentes até os dias hoje em nossas telenovelas.

Segundo Thomasseau (2005, p. 10), o melodrama, desde seu nascimento, foi recriminado e tratado com ironia por seus críticos, pois era associado à ideia de um teatro popular e de gosto duvidoso. Destaca também Meyer (1996, p. 157), nesse sentido, que:

Os grandes gêneros populares do século XIX engendraram todo um campo semântico intercambiável e de carga altamente pejorativa. Melodrama, melodramático, folhetim, folhetinesco conotando previsíveis e redundantes narrativas, sentimentalismo, pieguice, lágrimas, emoções baratas, 
suspense e reviravoltas, linguagem retórica e chapada, personagens e situações estereotipadas etc.

Para Thomasseau (2005, p. 9), porém, embora esse esquema não seja falso, assim como qualquer estereótipo, é, decerto, redutor:

A palavra melodrama, com efeito, traz ao pensamento a noção de um drama exagerado e lacrimejante, povoado de heróis falastrões derretendo-se em inutilidades sentimentais ante infelizes vítimas perseguidas por ignóbeis vilões, numa ação [...] que embaralha todas as regras da arte do bom senso, e que termina sempre com o trinfo dos bons contra os maus, da virtude sobre o vício. Este esquema, se não é inteiramente falso, é por demais simplificador.

É digno de nota que algumas obras romanescas, publicadas nos rodapés dos jornais, deixaram sua marca na temática e na tipologia dos melodramas: A História dos Treze (1842-1848), de Balzac, As memórias do Diabo (1837), de F. Soulié e, sobretudo, Os Mistérios de Paris (1842-1843) e o Judeu Errante (1844), de Eugène Sue, conforme relata Thomasseau (2005, p. 71).

A pequena pausa no universo melodramático justifica-se ainda por mais uma razão. Conforme veremos, ainda neste capítulo, na seção sobre Barthes e a estrutura do fait divers, um dos elementos que constituem esse tipo de relato jornalístico repousa naquilo que o autor chama de dramatis personae, típicos do gênero melodramático:

Os personagens do melodrama são personae, máscaras de comportamentos e linguagens fortemente codificadas e imediatamente identificáveis. [...] O melodrama se encontra, assim, inteiramente voltado para o enfretamento de personagens de comportamento estereotipado e perfeitamente inserido num ritual cênico convencional cujas 
regras, de todos conhecidas, facilitam a leitura (THOMASSEAU, 2005, p. 39, 44).

Segundo Huppes (2000, p. 150), a influência do melodrama no relato dos faits divers é o "toque ficcional no processamento narrativo dos acontecimentos. Desaparecem as pessoas, as quais devem ceder lugar às personagens. Estas são alocadas nos papéis consagrados pela tradição" (HUPPES, 2000, p. 150-151). Assim, o público acostumado ao melodrama identifica, facilmente, quem são os heróis e os vilões.

Mostra ainda Thomasseau (2005, p. 139) que "o estilo dos diálogos, evidentemente, não tem lugar num tal universo: a intriga de um melodrama não é jamais bem escrita, mas sempre bem descrita", tal como, a nosso ver, também são os faits divers. Segundo Huppes (2000), no campo do jornalismo, as técnicas melodramáticas também são altamente utilizadas, e, acrescentaríamos, ainda, principalmente no universo desse relato noticioso:

[As coberturas jornalísticas] passam ao largo de aspectos do comportamento comum, desviam de costumes partilhados por toda a gente no cotidiano. Preferem voltar-se para acontecimentos de impacto. A câmera abre para a máxima riqueza de detalhes. Exóticos e brutais de preferência (HUPPES, 2000, p. 150).

No entender de Amaral (2011, p. 73), o melodrama “é uma espécie de macrogênero que inclui a telenovela, o folhetim, o radio teatro, a literatura de cordel, entre outros". Entre esses “outros” está, para nós, notadamente, o fait divers.

Eis, portanto, os elos entre melodrama, folhetim e fait divers. Com o adendo desta seção, seguem outros aspectos relativos a este último. 


\subsection{O FASCÍNIO PELO FAIT DIVERS}

Alguns eminentes pensadores do século XX se interessaram pelo fait divers. Uma das razões, segundo Merleau-Ponty (1991, p. 349), é que talvez não haja nenhum fait divers "que não possa dar ensejo a pensamentos profundos". O fenomenólogo narra um pequeno episódio que presenciou na Itália de Mussolini, que, muito provavelmente, pode ter estampado as seções dos periódicos de então dedicadas ao fait divers:

Lembro-me de ter visto, na Itália fascista, na estação de Gênova, um homem atirar-se do alto de um aterro para os trilhos. A multidão acorria. Antes mesmo de pensar em socorrer o ferido, os "milicianos ferroviários" a recuavam duramente. Aquele sangue perturbava a ordem, era preciso apagá-lo bem depressa, e fazer com que o mundo retomasse o aspecto tranquilizador de uma noite de agosto em Gênova. Todas as vertigens são semelhantes. Ao ver morrer um desconhecido, aqueles homens poderiam ter aprendido a julgar a vida deles. Defendiam-nos de alguém que acabava de dispor da sua (p. 349).

Conforme Merleau-Ponty: “O gosto pelas notícias do cotidiano [fait divers] é o desejo de ver, e ver é adivinhar numa ruga do rosto um mundo inteiro igual ao nosso (p. 349)" ${ }^{28}$. É, assim, por meio de uma espécie de identificação do enunciatário com o fait divers que surge o fascínio.

Para Levinas (2011, p. 63), entretanto, a relação com o "outro", e, ainda, poderíamos afirmar, por contiguidade, com a alteridade constitutiva do fait divers, não se dá senão por uma via conflituosa:

\footnotetext{
${ }^{28}$ Embora a tradução brasileira tenha optado por traduzir o termo fait divers por "notícias do cotidiano", preferimos manter, na citação, o termo original, entre colchetes, que, a nosso ver, não possui uma tradução exata no português.
} 
O outro não é de modo algum um outro eu, participando comigo numa existência comum. A relação com o outro não é uma relação idílica e harmoniosa de comunhão ou uma simpatia pela qual nos colocamos no lugar do outro; reconhecemos o outro como parecidos conosco, mas como exterior a nós; a relação com o outro é uma relação com um Mistério.

Outra razão para a existência de tamanho interesse por esse tipo de relato é a transgressão dos valores e normas vigentes que eles promovem. Segundo Morin (2011, p. 93), o fait divers:

Infringe a ordem das coisas, viola os tabus, compele ao extremo a lógica das paixões. Tem em comum com a tragédia o fato de se sujeitar à implacável fatalidade. É esse universo de sonho vivido, de tragédia vivida e de fatalidade que valoriza os jornais modernos do mundo ocidental. A imprensa seleciona as situações existenciais carregadas de uma grande intensidade afetiva (as crianças mártires apelam para a afetividade materna, os crimes passionais apelam para a afetividade amorosa, os acidentes apelam para o pathos elementar).

Cabe dizer também que as estruturas do fait divers são, para Morin (2011), as do imaginário, tanto como o são as do romance-folhetim e as dos filmes nos moldes hollywoodianos: todos ancorados no melodrama. No entanto, há uma diferença: "O filme de happy end é providencial; ele poupa seus heróis [...]. O fait divers [por sua vez] é trágico: a fatalidade se abate sobre vítimas inocentes; a morte se apropria cegamente tanto dos bons quanto dos maus" (MORIN, 2011, p. 109).

Esse autor (2011, p. 109) destaca ainda que notícias da ordem do "horrível, do ilícito, do destino e da morte na vida cotidiana" são atenuadas pela forma de consumo dos faits divers. Lidos (ou assistidos/ouvidos) à mesa do café da manhã ou a caminho do trabalho, aqueles mortos, ainda que 
"reais", estão longe do leitor/espectador: "a catarse é como que digerida no cotidiano, isso quer dizer que o grande tema do sacrifício, 'eles morrem em meu lugar', se atenua em um ‘são os outros que morrem e não eu’” (p. 110).

Nesse sentido, ressalta Maffesoli (1988, p. 91): "Como o conto, o carnaval, o jogo infantil, o comentário do fait divers permite falar, sem propriamente fazê-lo, da morte, da violência, do sexo, das leis e sua transgressão".

De acordo com o já citado prefácio do catálogo da exposição sobre fait divers organizada pelo Musée National des Arts et Traditions Populaires de Paris, transcrito de Meyer (1996, p. 100):

Funcionando como um romance, o relato desse tipo de acontecimento convida o leitor a participar por meio da imaginação das situações descritas e a se identificar com os personagens cujas aventuras acompanha [...]. Transgredindo [...] as sujeições de ordem e de moral que fixam os limites acanhados de sua vida, o leitor pode, sem deixar o vagão do metrô ou seu ônibus, e sem perder seu jeito "fino", executar pela imaginação as ações impossíveis e principalmente proibidas - desejo, quem sabe, que ele carrega lá no fundo... A crônica do fait divers aparece como o lugar da satisfação simbólica das mais elementares frustrações $[. .$. onde se busca o equivalente ilusório de uma experiência total do homem, através do excepcional, do atípico, do desviante, a viver ficticiamente a impossível transgressão da ordem social.

A leitura desse relato noticioso de ordem transgressora, portanto, relaciona-se com o que Morin (2011, p. 110) chama de experiências 
"projetivas", ou com expressão de Angrimani (1995, p. 152) "morte por procuração" ${ }^{29}$.

Para Merleau-Ponty, "as notícias do cotidiano [fait divers] impressionam porque são a invasão de uma vida naquelas que a ignoravam" (1991, p. 352). É o cotidiano do outro - que, muito bem, poderia ser o nosso - que se agiganta diante de nós. Em uma reflexão semelhante, Foucault (1977, p. 215) afirma que o fait divers promove uma mudança de escala dos fatos pequenos e desconhecidos do dia-a-dia:

É preciso prestar atenção nestas palavras que tão frequentemente reaparecem nos títulos dos panfletos fait divers]: detalhe, circunstância, explicação, acontecimento ${ }^{30}$. Elas designam, com efeito, muito bem, a função dessa espécie de discurso em relação à importância que os jornais e livros davam aos mesmos fatos: mudar de escala, aumentar proporções, fazer aparecer o grão minúsculo da história, abrir ao cotidiano o acesso da narração.

O fait divers funciona, assim, como uma lupa sobre o cotidiano, narrando pequenos fatos, o grão minúsculo da história, nas palavras de Foucault. Para empreender essa operação, é preciso:

Por um lado, fazer entrar na narrativa elementos, personagens, nomes, gestos, diálogos [...], por outro lado,

\footnotetext{
${ }^{29}$ Na leitura psicanalítica empreendida por Angrimani (1995), o jornal sensacionalista e, por extensão, o fait divers, seu principal ingrediente, atuaria como "um ‘id personificado' por ser o meio de o leitor enveredar pelo inconsciente e o recalcado, realizando, por procuração, pulsões reprimidas" (p. 152).

${ }^{30}$ Fiorin (1990, p. 93), ao propor uma tipologia de textos com base nas fases da narrativa, afirma sobre os jornais sensacionalistas, cujo discurso relata principalmente fait divers: "crimes, escândalos, contravenções, explora fundamentalmente a performance. Descreve com detalhes como agiu o sujeito operador, mostra com minúcias requintes de sadismo, conta quantas facadas recebeu o morto, etc.".
} 
[que] todos esses pequenos acontecimentos, apesar de sua frequência e monotonia, surjam como singulares, curiosos, únicos, ou quase, na memória dos homens. É assim que tais relatos podem fazer o papel de cambiadores entre o familiar e o notável, entre o quotidiano e o histórico (FOUCAULT, 1977, p. 216).

Dessa maneira, o fait divers abre uma brecha no cotidiano, ou melhor dizendo, dá a ver esse cotidiano do outro, no qual, de certa forma, reconhecemo-nos, ainda que por uma via conflituosa. Um dos principais temas do fait divers é, com efeito, o assassinato, "o ponto de cruzamento da história e do crime. [...] É o assassinato que assegura o sombrio renome dos criminosos", segundo Foucault (p. 217). Segundo o autor, para a memória popular, que "se tece na circulação dessas folhas de notícias [fait divers], o assassinato é o acontecimento por excelência” (p. 217).

\subsection{ESTRUTURA BARTHESIANA DO FAIT DIVERS}

Como já foi objeto de comentário, apesar da pré-existência do termo e do interesse de inúmeros pensadores pelo tema, a elaboração do conceito desse tipo de notícia, no que se refere fundamentalmente à concepção de uma estrutura, remete, decerto, a Barthes (1964). Tanto o é que tal conceito tornou-se referência obrigatória a qualquer abordagem que se faça do fait divers. Este se refere, segundo o autor, a notícias acerca de eventos de caráter grotesco, em geral da ordem do privado. Em uma palavra, trata-se de uma informação "monstruosa" (p. 194).

Barthes diferencia o fait divers de outras editorias jornalísticas ao comparar dois tipos de assassinato: um, por razões políticas, e um segundo, 
por exemplo, um crime passional. O do primeiro tipo necessariamente remete a um conhecimento exterior ao fato propriamente dito, ou seja, à conjuntura política, às razões daí decorrentes que motivaram tal assassinato, etc. "Em suma, o assassinato escapa ao fait divers sempre que ele for exógeno, vindo de um mundo já conhecido [...]. O assassinato político é, portanto, sempre uma informação parcial", afirma Barthes (1964, p. 195). O fait divers, conforme o autor, ao contrário, prescinde de dados pré-existentes, constituise como uma informação total, "contém em si todo o saber: não é necessário nada do mundo para consumir um fait divers; ele não remete formalmente a nada senão a si próprio” (p. 195). Seu conteúdo, entretanto, não é estranho à "realidade" que nos cerca: são geralmente desastres, mortes, acidentes e bizarrices em geral: "sem duração e sem contexto, ele constitui um ser imediato, total, que não remete a nada de implícito [...]. É sua imanência que define o fait divers" (p. 195; itálicos nossos).

Na concepção de Barthes, as relações imanentes ao fait divers podem ser de dois tipos. A primeira é a de causalidade, em geral, aberrante. Por isso, ele traz consigo, nas palavras do semiólogo (1964, p. 197), "um germe de degradação". Esse tipo de estrutura subdivide-se em duas formas de causalidade: a causa perturbada e a causa esperada. Na do primeiro tipo, não se sabe da causa do evento, ou, ainda, uma pequena causa gera um grande efeito. No segundo tipo de causalidade, a importância da relação perde força - ainda que continue presente - e a ênfase é posta sobre o que autor chama de dramatis personae, como, por exemplo, uma criança, um idoso, uma madrasta - "tipos de essências emocionais, encarregadas de dar vida a um estereótipo"(p. 197). 
O segundo tipo de relação imanente, segundo Barthes, é o de coincidência, o qual se subdivide, igualmente, em dois subtipos: repetição e antítese. Alguém que ganha na loteria mais de uma vez, ou, ainda, contrariando a expressão popular, um raio que cai duas vezes no mesmo lugar constitui um fait divers pelo caráter inesperado da repetição. No caso da antítese, duas lógicas opostas constituem esse tipo de relação imanente.

Tomemos o Caso Isabella Nardoni para exemplificar. No que se refere à relação de causalidade, inicialmente, desconhecia-se o motivo da morte da menina, isto é, configura-se uma causa perturbada, pela definição de Barthes (1964). Ao mesmo tempo, esse fait divers ancora-se num segundo tipo de relação de causalidade, no qual a ênfase é posta sobre as dramatis personae: estão em jogo as figuras da criança, do pai, da madrasta que remontam aos estereótipos que repousam na cultura. No que tange à relação de coincidência, o evento, obviamente, não se dá por repetição, mas por antítese. No Caso Isabella Nardoni, a menina é assassinada pelo próprio pai, com ajuda da madrasta. Aquele, portanto, que seria o responsável pela criação e bem-estar da filha, paradoxalmente, é o causador de sua morte:

O pai, inclusive, com formação universitária. É um advogado. Isso parece não ter sido o suficiente, para impedir o evento trágico. [...] O jogar uma menina, de quatro anos [na verdade, cinco anos], pela janela de um prédio, de classe média, do sexto andar, com uma altura aproximada de 20 metros, é uma singularidade trágica. Contraria a própria configuração do trágico usual e urbano. Oferece uma ruptura ao Estereótipo vigente.[...] Isabella perde a vida pelas mãos de quem a dera - o seu pai, conforme a acusação. [...] Alexandre Nardoni, responsável pelo cuidado, pelo amparo da menina, torna-se réu pelo seu assassinato. Ele, um advogado, que deveria ser o paladino das leis, parece ser o seu fiel 
transgressor, cultivando a Antítese - pai e provável assassino (RAMOS, 2008, p. 144-145) ${ }^{31}$.

Assim, pelas categorias postuladas por Barthes, o Caso Isabella Nardoni constitui-se como um fait divers por excelência.

Cabe dizer ainda que, pela proposição barthesiana, não há fait divers sem o susto, sem o espanto de quem vê, lê ou assiste. A temática pode ser ainda de dois tipos: crimes (crimes passionais, suicídios, chantagens, agressões sádicas) e fenômenos [prodige], da ordem do inesperado, tais como notícias sobre supostos discos voadores, fenômenos paranormais, religiosos, etc. Dion (2007, p. 126), nesse sentido, destaca a pouca variabilidade temática do relato noticioso em questão: "De fato, parece que o fait divers é eminentemente repetitivo". Observa-se, entretanto, uma particularidade desse pequeno inventário temático: são sempre marcados por um forte caráter fortuito e emocional.

Barthes (1964), nesse ensaio pleno de ideias, lança luz para o estudo do fenômeno dos faits divers, e indica caminhos capazes de suscitar ainda outras questões. Propomos fazê-lo, conforme anunciamos, pelo viés da semiótica tensiva. Antes, entretanto, é necessário sublinhar a diferença entre o que Barthes (1964) entende por estrutura/imanência e como o faz a semiótica de bases greimasianas.

Para a semiótica, a definição de Barthes para tais notícias (a exemplo do crime político - que necessitaria de informações exógenas a ele mesmo -

\footnotetext{
${ }^{31}$ Quando da publicação do texto de Ramos (2008), o casal suspeito não havia ainda sido julgado e condenado.
} 
diferente de um crime passional), apesar de estrutural ${ }^{32}$, não constituiria sua imanência. Aos olhos da disciplina de Greimas, são preliminarmente as relações intratextuais ali engendradas que criariam efeitos de sentido específicos desse tipo de relato. É por esse caminho, portanto, que conduzimos nossa investigação a respeito do fait divers.

Sabe-se, entretanto, que a semiótica não ignora a "exterioridade discursiva", termo semiotizado por Barros (2009); todavia, aborda-a a partir de metodologias que não contradigam o primado da imanência, que incluem, por exemplo, as relações intertextuais ou interdiscursivas que o texto em análise estabelece com outros textos/discursos.

Pela exemplificação de Barthes, a não necessidade de contexto especificaria o fait divers, enquanto sua imprescindibilidade definiria aquilo que não o é. Sem pretender fazer uma leitura estrita da máxima greimasiana, segundo a qual "fora do texto não há salvação" (GREIMAS, 1974, p. 25), admitimos que são suas próprias categorias em relação que definem tal imanência. Desse modo, o conceito de estrutura, segundo Hjelmslev (1991, p. 29), "entidade autônoma de dependências internas", ao qual subjaz o conceito de imanência, encontra-se, a nosso ver, atual para o estudo das relações intratextuais de quaisquer textos, entendidos em sentido lato.

\footnotetext{
${ }^{32}$ Lembre-se que os termos estrutural e estruturalismo não constituem expressões unívocas. No dizer de Dosse (2007, p. 25), "os contornos da referência estruturalista são sobremaneira vagos, difusos". Segundo o autor, não há senão estruturalismos, no plural. No que respeita a esta pesquisa, entretanto, entendemos estruturalismo a partir do conceito hjelmsleviano de estrutura.

${ }^{33}$ Até porque cabe ao analista definir a semiótica-objeto, isto é, o que é texto e o que não é numa determinada análise. Nesse sentido, assevera Fontanille (2008, p. 19): “Assim, o slogan greimasiano deveria ser hoje reformulado: 'Fora das semióticas-objeto não há salvação!', cabendo a nós definir o que são essas 'semióticas-objeto"”.
} 


\subsection{SEMIÓTICA TENSIVA E FAIT DIVERS: primeiras aproximações}

Barthes (1964) esboçou, a partir de seu ensaio, uma espécie de "semiótica do acontecimento" avant la lettre, concebida e assim denominada por Zilberberg (2011a, p. 46). A ausência de duração, a intensidade com que ele se dá, as paixões, nomeadas ou não, suscitadas e intrínsecas a tais informações inesperadas, pontuais e "monstruosas" são, ao que queremos demonstrar, passíveis de serem transpostas a uma "abordagem tensiva do fait divers".

Nesse sentido, Alencar (2005, p. 116), na esteira do pensamento barthesiano, ressalta a intensidade constitutiva do fait divers e a temporalidade posteriormente demandada para apreendê-lo:

Entre um suicídio, um naufrágio, o nascimento de uma criança deformada ou um caso de canibalismo, o que haveria em comum, além de terem ocorrido "de fato" e de marcarem o limite do humano? O que diferencia um fait divers de outros tipos de notícia? Assim como todo acidente, o fait divers interroga a visibilidade das coisas. Diante do incompreensível, os preconceitos e a tentação jornalística de tudo explicar - tudo e imediatamente - recuam, perdem terreno. [...] $O$ vivenciado se configura, tornando-se processo, traduzindo-se em temporalidade, ou seja, a vida busca inteligibilidade através da narrativa (itálicos nossos).

A autora observa ainda a rapidez e a não serialidade, características do fait divers, ao afirmar:

Este $\left[\begin{array}{ll}\text { o leitor}\end{array}\right.$ é seduzido pelo princípio de uma desorganização generalizada, como se algo viesse dizer que a vida é assim mesmo, irrisória, vertiginosa, confusa. Os outros tipos de notícia se aproximam do romance, expressão 
da totalidade e da longa duração, que supõe uma serialidade que o fait divers desconhece (ALENCAR, 2005, 118-119; itálicos nossos).

Assim, tal como o acontecimento zilberberguiano, o referido conceito de Barthes não possui duração, é da ordem daquilo que afeta, do intenso, do universo do sensível, do passional, do estésico.

Dion (2007, p. 125) também ressalta que: "o fait divers é sempre a narração de uma transgressão qualquer, de um afastamento em relação a uma norma (social, moral, religiosa, natural)". A afirmação da autora vem ao encontro de outra característica do conceito de acontecimento postulado por Zilberberg (2011a): seu caráter transgressor, inesperado, enfim, concessivo.

Dessa forma, temos elementos para conjecturar que o estilo concessivo de que fala Zilberberg (2011a, 2011b), que leva em consideração a realização do irrealizável, do fortuito, parece subjazer à estrutura do fait divers. É possível, assim, sugerir que a concessão se encontra nos substratos das relações imanentes propostas por Barthes (1964): causalidade e coincidência.

Vejamos de que maneira tais relações, propostas por Barthes (1964), encontram ressonância na teoria de Zilberberg. Em primeiro lugar, pensemos na relação de causalidade: a "relação de causalidade aberrante" é o oposto daquilo que se espera, portanto, do estilo implicativo (se... então). Consideremos agora ofait divers cuja relação de causalidade (causa esperada) perde força e o acento é posto sobre as dramatis personae: são figuras que carregam uma carga tímica muito elevada. Por exemplo, à figura da mãe que perde um filho, subjaz, no imaginário popular, a mater dolorosa, a Pietà, ou, 
como é conhecida em português, Nossa Senhora das Dores ${ }^{34}$. Ou, ainda, a criança, cuja figura remete ao sentido de início do ciclo da vida, e a do idoso, por sua vez, ao fim de uma trajetória. Retomando a citação de Barthes (1964, p. 197), as dramatis personae são "tipos de essências emocionais, encarregadas de dar vida a um estereótipo" (itálicos nossos). São figuras, portanto, que subtendem uma base figural de natureza eminentemente intensa.

Pensemos agora, ainda à luz do conceito zilberberguiano de acontecimento, nas relações de coincidência do fait divers. O termo coincidência comporta muitos traços sêmicos em comum com outros termos como acaso, fortuito. São eventos da ordem do inesperado, portanto. No que se refere ao primeiro tipo de coincidência, há a repetição. Todavia, não se trata de uma repetição no sentido de "a ordem natural das coisas", ou da repetição que pauta o cotidiano, ou, ainda, aquela da linha de montagem fordista, parodiada, por exemplo, em Tempos modernos, de Chaplin. A repetição aqui possui sempre um quê de insólito, de monstruoso, tal como na seguinte manchete do portal de notícias G1 ${ }^{35}$ : "Número de mulheres estupradas em festa na PB sobe para 6, diz delegada”. Isso porque a repetição, baseada no senso comum, é distributiva e não reiterativa.

O segundo tipo de relação de repetição é a antítese, isto é, a oposição de duas lógicas distintas. Tal figura da retórica encontra ressonância na proposta zilberberguiana de estilo concessivo, que remete à realização do irrealizável. Em ambos os casos, ocorre o contrário do que se espera.

\footnotetext{
${ }^{34}$ Encontramos respaldo para nossa argumentação no trabalho Lima (2010, p. 79-80), em que a autora analisa as relações intertextuais entre a fotografia de uma mãe com o filho morto nos braços e a obra Pietà, de Michelangelo.

${ }^{35}$ Disponível em: http://g1.globo.com/paraiba/noticia/2012/02/numero-de-mulheres-estupra das-em-festa-na-pb-sobe-para-6-diz-delegada.html. Acesso em: jul. 2012.
} 
Para Ramos (2008, p. 142), a abordagem barthesiana do fait divers:

Oferece-lhe uma estrutura, com duas categorias: a Causalidade e a Coincidência. Ambas estão direcionadas, para a classificação da excepcionalidade, fixada na dimensão do conflito, respectivamente, através da Causa Perturbada e Causa Esperada, da Repetição e da Antítese. Revela-lhe a Fatalidade, como Sujeito Absoluto, análogo ao "Deus-exMachina" da linguagem trágica.

O autor, ao sintetizar as relações barthesianas desse tipo de notícia, permite que nos apoiemos em sua asserção no sentido de que se entrevejam semelhanças entre os conceitos de fait divers e de acontecimento. Essa primeira aproximação entre tal conceito de Barthes (1964) e a gramática tensiva mostra algumas interseções a serem exploradas ao longo desta tese ${ }^{36}$. Nosso objetivo é, desse modo, semiotizar o fait divers, teorizando-o, ao depreender-lhe (in)variantes por meio das análises que se apresentam no decorrer deste estudo, que, ao fim e ao cabo desta tese, resultam numa abordagem tensiva do fait divers.

\footnotetext{
${ }^{36}$ Embora, no final deste capítulo, tenhamos começado a usar, sem maiores explicações, alguns termos da semiótica tensiva, no Capítulo 2, elucidamos pormenorizadamente os elementos dessa gramática, que dão subsídio à análise do corpus.
} 


\section{2}

\section{[Sentido e tensividade]}

"Não estamos interessados [...] na constatação trivial da presença de uma isotopia afetiva no discurso, e sim na compreensão de sua

repercussão.”

Claude Zilberberg 


\subsection{SEMIÓTICA TENSIVA: sobre o contínuo e o afeto}

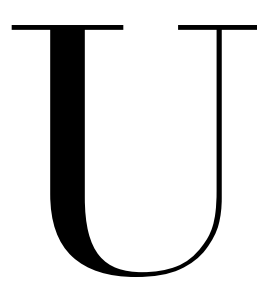

ma abordagem tensiva do fait divers, tal como indica o título desta tese, estabelece-se pelo viés da tensividade, que, em linhas gerais, concede espaço privilegiado ao contínuo e à afetividade no discurso. O presente capítulo, assim, apresenta os principais elementos da semiótica de vertente tensiva (Cf. FONTANILLE; ZILBERBERG, 2001; ZILBERBERG, 2007, 2011a, 2011b), que dão os subsídios necessários à análise do corpus deste trabalho.

Não é demais afirmar que, se a significação se constitui a partir de unidades discretas, a essa discretização subjaz um continuum, que já é uma potencialidade de sentido (Cf. GREIMAS; FONTANILLE, 1993, p. 10, 15). Assim, o ponto de vista tensivo estabelece-se em complemento e não em substituição à semiótica greimasiana. Não se trata, portanto, de trocar o discreto pelo não discreto, pois, como afirma Zilberberg (2011a, p. 16): “a 'casa do sentido' é vasta o bastante para acolher tanto o contínuo, quanto o descontínuo, mesmo porque nem este nem aquele fazem sentido por si mesmos, mas apenas por sua colaboração".

No que tange à continuidade, a semiótica tensiva oferece à teoria greimasiana a noção de gradação, sem a qual não seria possível analisar determinados fenômenos cuja característica principal não é a oposição, mas a diferença em algum grau, ou, nas palavras de Zilberberg (2011a, p. 14), o "intervalo":

Dizer que $[a]$ se opõe a $[\mathbf{b}]$ equivale a dizer que $[a]$ se afasta "em maior ou menor medida" de [b], e que esse afastamento 
tem de ser avaliado pela simples razão de que ele corresponde à sua própria definição! Tal escolha leva a conceber, entre $[a]$ e $[\mathrm{b}]$, um vão, um intervalo, ocupando-o ou preenchendo-o de alguma maneira (p. 22).

Tomemos, assim, o seguinte exemplo: o "quente" se opõe ao "frio", termos considerados contrários no quadrado semiótico. Entretanto, o "morno" se difere tanto do "quente" quanto do "frio". Entre tais elementos, portanto, existe um intervalo em relação ao valor que cada um deles possui. Também poderiam ser acrescidos, nesse continuum, o "morno-quente" e o "morno-frio", termos que, no quadrado semiótico, seriam chamados de contraditórios ("não frio" e "não quente", respectivamente), conforme pode ser visto a seguir:

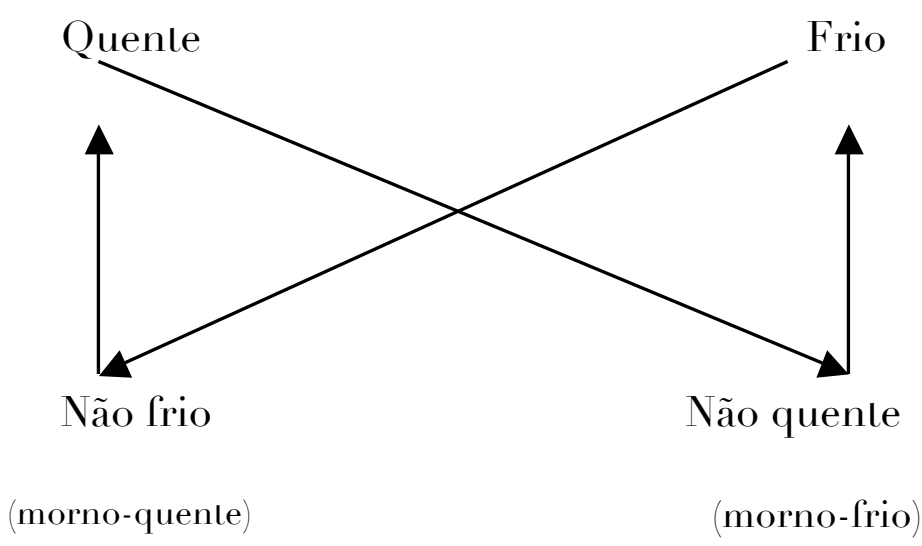

Entretanto, além desses, poder-se-iam pensar em inúmeras possibilidades, numa escala gradual, entre o "quente" e o "frio". Pode-se, inclusive, incluir num dos polos dessa gradação o termo mais frio que o frio (gélido) e, no outro, o mais quente que o quente (escaldante). Assim, pelo 
ponto de vista tensivo, estabelece-se uma gradação que vai do frio ("gélido") até o mais quente ("escaldante"), ao invés de se opor o "quente" ao "frio", conforme se vê a seguir:

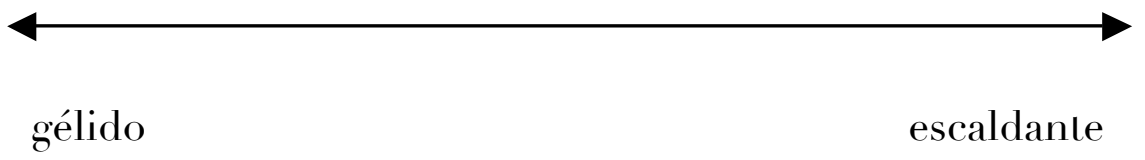

Pela representação gráfica acima, são inúmeras as possibilidades - os intervalos - entre o "gélido" e o "escaldante". Tratar o sentido pela ótica da tensividade, do contínuo, permite-nos, conforme dissemos, abordar fenômenos cujo sentido se estabelece de forma gradual.

Os termos "gélido" e "escaldante", que propusemos a partir do par "frio" vs. "quente", pela terminologia de Zilberberg (2011a), são chamados de sobrecontrários. Tais termos carregam, por assim dizer, um germe concessivo. Isso porque, por uma lógica implicativa (da ordem do "se... então"), está previsto esquentar o frio ou esfriar o quente, uma vez que o frio pressupõe o quente e vice-versa. No entanto, esquentar o gélido (mais frio que o frio) ou esfriar o escaldante (mais quente que o quente) já significa acionar uma lógica concessiva, uma operação não prevista (da ordem do 
“embora... entretanto"). Na tabela a seguir, pode-se observar a representação dos termos subcontrários e sobrecontrários em questão ${ }^{37}$ :

\begin{tabular}{|c|c|c|c|}
\hline GÉLIDO & FRIO & QUENTE & ESCALDANTE \\
\hline termo & termo & termo & termo \\
sobrecontrário & subcontrário & subcontrário & sobrecontrário \\
\hline
\end{tabular}

Essa exemplificação, a partir de um exemplo simples ("quente" os. "frio"), mostra como o nível tensivo resulta de uma leitura de natureza gradiente do nível fundamental do percurso gerativo greimasiano, no qual o quadrado semiótico representa as oposições semânticas de base dos textos. Para Fontanille (2007, p. 74), o quadrado semiótico:

Reúne diferentes tipos de oposição para deles fazer um esquema coerente. Todavia, ele apresenta a categoria como um todo já acabado, que não está mais sob o controle de uma enunciação viva. Ademais, em sua versão clássica, transforma a categoria em um esquema formal que não mantém mais relação alguma com a percepção e a abordagem sensível dos fenômenos.

Segundo ainda o autor (FONTANILLE, 2007, p. 75), um modelo que contemple as estruturas elementares da significação, tal como o tensivo, deve dar conta principalmente das conexões entre o sensível e o inteligível e de respeitar a complexidade dos fenômenos tal como se apresentam no discurso.

37 O termo "subcontrário", pela leitura tensiva de Zilberberg (2011a, p. 281-282), corresponde ao termo "contrário" do quadrado semiótico. 
Landowski (2002, p. 130), por seu turno, ressalta “a necessidade de superar a concepção dualista 'sensitivo' versus 'cognitivo' - que a mais ampla tradição filosófica nos impõe como ponto de partida”. Cabe dizer que, apesar das diferenças entre as proposições deste autor, estudioso de uma "semiótica das experiências sensíveis", em relação às da semiótica tensiva, sobre esta questão - primordial, diga-se -, estabelece-se um ponto pacífico que é justamente não tomar o inteligível e o sensível como duas instâncias que funcionam em separado, mas, ao contrário: o concebido e o vivenciado se implicam e se condicionam mutuamente num processo em que um não tem existência própria sem o outro: "A particularidade do ponto de vista tensivo [consiste em] discernir as condições de uma reciprocidade ininterrupta do afeto e da forma” (ZILBERBERG, 2011a, p. 45).

Não se trata, entretanto, de uma correlação em condições iguais de força, por assim dizer. A semiótica tensiva concede primazia, nesse processo, ao afeto, à intensidade, a qual é regente da extensidade (questão à qual ainda voltaremos). Por isso, aos olhos de Zilberberg (2011a, p. 14), a teoria tensiva "contenta-se em apresentar um ponto de vista que realça algumas grandezas até então tidas por irrelevantes, as grandezas afetivas" ${ }^{38}$. O autor, assim, defende uma dependência do sentido em relação à afetividade.

\footnotetext{
${ }^{38}$ Em que pese tal afirmação, Zilberberg (2011a, p. 42), algumas páginas depois, assevera: "Lembremos, todavia, o conhecido exemplo do quadrado semiótico, cujas premissas eram em princípio lógico-semânticas, mas que, para 'funcionar', necessitava da foria, a qual certamente não é de natureza lógico-semântica". Ora, se o quadrado semiótico, uma das mais conhecidas ferramentas da teoria greimasiana, compõe-se, além de relações lógicosemânticas, de uma força motriz de natureza afetiva, não é o caso de a semiótica anterior à semiótica tensiva ter tomado o afeto como um elemento de natureza irrelevante. A nosso ver, para a semiótica clássica, não era uma questão pertinente pensar o lugar do sensível na significação, questão essa que começou a despontar apenas em Semiótica das paixões e Da imperfeição.
} 
Acerca dessa questão, a semiótica tensiva e a psicanálise têm no afeto o ponto central de seus interesses ${ }^{39}$. Todavia, enquanto esta o toma através do conceito de pulsão, uma espécie de força motriz inconsciente dos sujeitos, aquela pensa a afetividade em termos de $\operatorname{sincronia}^{40}$ :

Enquanto a psicanálise afirma uma anterioridade insuperável da afetividade, que reduz o presente à condição de um rebento, uma hipotipose mal dissimulada do passado remoto do indivíduo (o chamado "recalque"), nós, de nossa parte, pensamos a afetividade na sincronia, como um conjunto de funções descritíveis, analisáveis e sobretudo ‘gramaticalizáveis'” (ZILBERBERG, 2011a, p. 27).

A "gramaticalização" do afeto em sua sincronia é, assim, um dos pressupostos fundamentais da semiótica tensiva:

Como poderíamos conceber que aquilo que afeta, comove o sujeito - irrompendo, em geral, de forma inesperada - não

\footnotetext{
${ }^{39}$ Ressaltem-se propostas, na interface entre semiótica e psicanálise, sobretudo em Beividas $(2006,2009)$ ' que oferecem uma perspectiva tanto sincrônica quanto diacrônica em relação à afetividade. Concebido à imagem do percurso gerativo de sentido greimasiano, o percurso gerativo do psiquismo inconsciente (BEIVIDAS, 2006) ou percurso gerativo da subjetividade (BEIVIDAS, 2009) constitui-se de três patamares de profundidade. No nível fundamental estão as pulsões, que caminham para uma instância intermediária, chamada pelo autor de patológica, em que se encontram as matrizes da clínica de Freud, como histeria, obsessão, que, por sua vez, chegam ao último nível, a instância passional, o lugar dos afetos e das paixões.

40 "Processo dinâmico que consiste numa pressão ou força (carga energética, fator de motricidade) que faz o organismo tender para um objetivo. Segundo Freud, uma pulsão tem a sua fonte numa excitação corporal (estado de tensão); o seu objetivo ou meta é suprimir o estado de tensão que reina na fonte pulsional; é no objeto ou graças a ele que a pulsão pode atingir a sua meta" (LAPLANCHE; PONTALIS, 2001, p. 394). Segundo os autores, essa noção se esboça a partir da descrição da sexualidade humana por Freud. O conceito freudiano diferencia-se da ideia de uma visão popular, que vincularia a pulsão a uma meta ou um objeto específico localizado nas excitações e no aparelho genital. Ao contrário disso, o objeto das pulsões é variável, contingente e tem sua forma escolhidas em função do histórico de cada um. A pulsão, diferentemente do instinto (próprio de uma espécie animal), é definida pelo criador da psicanálise como um conceito-limite entre o psiquismo e o somático.
} 
se instalasse de direito, no centro do campo discursivo? (ZILBERBERG, 2011a, p. 101)

Assim, para a semiótica tensiva, o afeto não pressupõe o discurso, mas lhe é sincrônico. Zilberberg (2011a, p. 12), ao conceber uma definição para a gramática tensiva, evoca o termo "gramática do afeto", expressão que, para ele, não equivale a um oxímoro. Portanto, por tal perspectiva, o afeto é gramaticalizável, pois constitui-se na e pela linguagem.

\subsection{SEMIÓTICA E VIVÊNCIA}

A importância concedida ao sensível a partir de Semiótica das paixões ${ }^{41}$ (GREIMAS; FONTANILLE, 1993) e Da imperfeição ${ }^{42}$ (GREIMAS, 2002) levaram a semiótica a passar pelo que Zilberberg (2011a, p. 12) denomina "virada fenomenológica" [tournant phénoménologique], a qual, aos olhos do autor, "efetiva ou não, justificada ou não [...] constitui uma intimação". Beividas (2011, p. 13) descreve bem como se dá essa "viragem" «3 : "um movimento de progressiva e global primazia do sensível sobre o inteligível, a

\footnotetext{
41 "Essa inegável ancoragem no sentido na afetividade, hoje assumida plenamente pela semiótica, estava latente desde aquilo que se denominou 'virada modal', mas foi preciso aguardar a obra Semiótica das paixões para que ela pudesse ser mais bem avaliada" (ZILBERBERG, 2011a, p. 45).

42 Acerca desta obra, afirma Oliveira (2002, p. 9): "De fato, além de inaugurar o tratamento semiótico das questões de estética, $D a$ imperfeição contribui decisivamente para a revitalização da semiótica geral, reintroduzindo nela as preocupações relativas à abordagem da dimensão sensível da significação - o que remete às origens fenomenológicas do projeto semiótico".

${ }^{43}$ Termo que prefere Beividas (2011) à "virada", para não dotar a expressão de um aspecto terminativo, da ordem do acabado.
} 
vantagem do afetivo sobre o cognitivo, a antecedência do percebido sobre o concebido".

Sabe-se, entretanto, que a influência de alguns pressupostos da fenomenologia na semiótica pode ser verificada desde o nascimento da teoria greimasiana, quando, por exemplo, em Semântica estruturalit , Greimas (1973, p. 15) trata da percepção como condição necessária a toda e qualquer produção de sentido, definindo-a como: "o lugar não linguístico onde se situa a apreensão da significação" O autor ainda declara:

A afirmação de que as significações do mundo humano se situam no nível da percepção consiste em definir a exploração no mundo do senso comum, ou como se diz, no mundo sensível. Pelo fato de serem os significantes $[\ldots]$ detectáveis, no momento da percepção, [...] são eles automaticamente remetidos ao universo natural manifestado ao nível das qualidades sensíveis (GREIMAS, 1973, p. 16-18).

Estabelece-se, assim, um ponto de intersecção entre fenomenologia e semiótica, ao cotejarmos a fala de Greimas a respeito da percepção com a seguinte asserção de Merleau-Ponty (2006, p. 280): "todo saber se instala nos horizontes abertos pela percepção”.

Outro ponto de cruzamento entre tais disciplinas encontra-se na premissa de que a condição humana é a do homo symbolicus: "Porque estamos no mundo, estamos condenados ao sentido" (MERLEAU-PONTY,

44 Para Beividas (2011, p. 14), não importa muito precisar a gênese "viragem fenomenológica" por que passa a semiótica: para uns, a vocação fenomenológica da semiótica já aparece em Semântica Estrutural, para outros, isso fica mais evidente em $D a$ imperfeição e em Semiótica das paixões, publicadas original e respectivamente em 1966, 1987, 1991. 
2006, p. 18). De forma correlata, para Greimas (1970, p. 12), "o homem vive em um mundo significante. Para ele, o problema do sentido não é colocado, o sentido é posto, ele se impõe como uma evidência, como um 'sentimento de compreensão' absolutamente natural". O semioticista também afirma: "O mundo humano se define essencialmente como o mundo da significação. Só pode ser chamado 'humano' na medida em que significa alguma coisa" (GREIMAS, 1973, p. 11).

Há, portanto, pontos em comum que subjazem tanto à fenomenologia quanto à semiótica. Entretanto, não obstante nosso conhecimento rudimentar acerca da seara filosófica, parece necessário assinalar algumas diferenças entre ambas as disciplinas, principalmente aquelas que saltam aos olhos de um semioticista.

Segundo Merleau-Ponty (2006, p. 1), para a fenomenologia, "o mundo já está sempre 'ali', antes da reflexão como uma presença inalienável”. Apontemos, assim, o que nos parece, a princípio, um ponto de divergência. Para a teoria greimasiana, o mundo natural é uma semiótica - a semiótica do mundo natural - à qual temos acesso por meio da relação com a semiótica da língua (GREIMAS; COURTÉS, 2008, p. 324-325). O mundo, para a semiótica, portanto, não está “ali” - senão perpassado pela linguagem. E aí está toda a diferença. Beividas e Ravanello (2006, p. 135) são felizes ao enunciar o que para nós impõe-se como pressuposto do estudioso da linguagem e dos discursos em geral: "A linguagem ou o discurso não cria o mundo ex nihilo, mas, uma vez em cena, o mundo está recriado à sua imagem e estrutura”.

Ainda sobre essa questão, Merleau-Ponty (2006, p. 296) afirma a respeito do mundo, do real, das coisas mesmas: "Temos a experiência de um mundo não no sentido de um sistema de relações que determinam inteiramente 
cada acontecimento, mas no sentido de uma totalidade aberta, cuja síntese não pode ser acabada" (itálicos nossos). Ora, sabemos que a semiótica, a partir de sua raiz hjelmsleviana, estruturalista, privilegia a relação em detrimento dos termos:

Os "objetos" do realismo ingênuo reduzem-se, então, a pontos de intersecção desses feixes de relacionamentos [...] Os relacionamentos ou as dependências que o realismo ingênuo considera secundários e como pressupostos dos objetos tornam-se, para nós, essenciais: são a condição necessária para que existam pontos de intersecção (HJELMSLEV, 2006, p. 28).

Assim, à primeira vista, já se podem notar alguns pressupostos distintos entre fenomenologia e semiótica, razão pela qual pensamos que não seria prudente considerar "a virada fenomenológica" da semiótica uma mudança de pilares teóricos. Por conseguinte, a semiótica tensiva, a nosso ver, não corresponde a uma "fenomenologização" da semiótica, mas, antes, a abordagem que concede lugar privilegiado à experiência e que, por isso, promove uma semiotização de alguns elementos da fenomenologia:

Na mesma medida em que a prevalência concedida ao percebido parece afastar a semiótica de suas referências linguísticas declaradas, a atenção que dedicamos $[\ldots]$ ao vivenciado e ao experienciado permite manter intacta, sem que se possa falar em paradoxo ou provocação, a referência linguística (ZILBERBERG, 2011a, p. 12).

Essa base linguística aludida por Zilberberg encontra continuidade na visão de Beividas (2011, p. 16, 31), a partir da qual, o autor concede primazia ao ato semiológico (relativo à linguagem) sobre o ato fenomenológico (relativo à percepção): 
Para compreender como locus de emergência do sentido, a verdadeira metamorfose qualitativa valencial e valorativa que a percepção humana opera por sobre um contínuo que os dados brutos, quantitativos e amorfos do real, apresentam ao sujeito, para então se tornar "mundo", a única maneira é ver tal percepção induzida pela contínua ação do pacto semiológico, portanto, percepção semiologizada ou semiotizada. [...] Noutros termos, o sujeito percebe não pelos órgãos do sentido mas pela organização de sua linguagem, percebe aquilo que a sua linguagem o levou a categorizar. A percepção humana é, antes, uma semiocepção.

Em suma, talvez fosse o caso de entender essa virada fenomenológica, na esteira da expressão utilizada por Beividas (2011, p. 14), como uma mirada fenomenológica, "tentando revitalizar o sentido latino do termo: mirar, admirar". Trata-se muito mais de uma inspiração, ou, como dissemos, de uma semiotização de alguns elementos da fenomenologia do que o contrário.

No que respeita especificamente à semiótica tensiva em sua relação com a fenomenologia, parece-nos importante ressaltar a preocupação daquela na esteira desta "[com] a relação existencial, imediata, imperativa entre o eu e o não-eu" (ZILBERBERG, 2011a, p. 41). Por isso, cabe enfatizar a diferença do sujeito greimasiano em relação ao sujeito da teoria tensiva. Segundo Zilberberg (2011a, p. 284), o sujeito do fazer, que se define pela relação de transformação (Cf. GREIMAS; COURTÉS, 2008, p. 488), “[...] torna-se competente e se desvencilha das dificuldades por antecipação”. Para a semiótica tensiva, o sujeito é o do sentir, do sofrer:

Quem é esse tipo de sujeito que, por vezes a contragosto, vê o acontecimento irromper e revirar seu campo de presença? É um sujeito sensível e, por catálise, sensível ao extremo ardor das subvalências de andamento e tonicidade que subjetivam o sobrevir do inesperado e precipitam sujeito da esfera familiar do agir para a esfera extática do sofrer (ZILBERBERG, 2011a, p. 284). 
Entretanto, a teoria prevê tanto um sujeito da apreensão, ou seja, que é invadido pelo objeto que adentra bruscamente o campo de presença sem qualquer aviso prévio quanto o sujeito do foco, que antevê a chegada do objeto, graças à lentidão de sua pervinda. Trata-se, nas palavras do autor, de um "sujeito ambivalente":

Esse exame superficial nos fornece uma fisionomia do sujeito ambivalente: a dualidade dos modos de eficiência [pervir vs. sobrevir] faz do sujeito do estado um ser ao sabor do acontecimento que o despoja, sem a menor cerimônia, das competências geradoras de sua confiança em si e de sua coragem diante das adversidades da vida cotidiana. Em compensação, a dualidade dos grandes operadores discursivos [implicação $v s$. concessão] atribui ao sujeito uma capacidade de denegação - segundo alguns, de revolta - que lhe permite contradizer diretamente o que lhe foi imposto (ZILBERBERG, 2011a, p. 285-286).

Portanto, a condição ambivalente do sujeito tensivo tanto faz dele um sujeito do fazer, pela ótica do pervir, como um sujeito do estado, um sujeito da estesia, pela ótica do sobrevir.

Assim, um dos conceitos advindos da fenomenologia de que se valeu a semiótica tensiva para lidar com a questão do sensível, do vivenciado, do experienciado, é, notadamente, o de "campo de presença”. Fontanille e Zilberberg (2001, p. 123) resgatam o conceito merleau-pontyano configurando a presença em termos dêiticos "a parir de uma espécie de presente linguístico":

Nosso ponto de partida estará constituído pela pressuposição recíproca entre, por um lado, "o campo de presença", considerado como o domínio espácio-temporal em que se exerce a percepção, e, por outro, as entradas, as estadas, as saídas e os retornos que, ao mesmo tempo, a ele 
devem seu valor e lhe dão corpo (FONTANILLE; ZILBERBERG, 2001, p. 123).

Pela perspectiva semiótica, o campo de presença se estabelece sincronicamente à chegada de um fato semiótico, ou seja, não preexiste ao discurso: as grandezas pervêm ou sobrevêm - lenta ou abruptamente - e ao fazê-lo, configura-se tal espaço. Logo, uma presença que adentra esse campo é sentida, em termos de intensidade, e quantificada, em termos de extensidade. Por isso, a grandeza semiótica é sempre relacional, tensiva e complexa, uma vez que, por um lado, correlaciona uma dimensão intensiva e, por outro, uma extensiva.

\subsection{ALGUNS CONCEITOS PRIMORDIAIS}

As duas seções que precederam a esta cumpriram o objetivo de apresentar, de forma geral, a semiótica tensiva. Esta seção, por sua vez, expõe conceitos basilares da teoria a partir dos quais realizamos a análise.

\subsubsection{Moedas de troca do sensível: mais e menos}

Segundo Zilberberg (2011a, p. 56), pela ótica tensiva, gradual, um discurso funciona visando à progressividade ou à degressividade. Para o autor, o par mais e menos funcionam como uma espécie de "moeda de troca" do sensível, da afetividade do discurso:

Simples e complicado a um só tempo o problema semiótico consiste em deduzir, a partir de uma categoria devidamente estabelecida, as unidades - quase diríamos: o dinheirinho 
trocado - que circulam entre os discursos, que penetram neles ou deles se retiram. É preciso flagrar as condições nas quais uma direção tensiva, isto é, afetante, fragmenta-se em momentos distintos, interdefinidos, e contudo dependentes no que diz respeito à direção tomada [...] o mais e o menos, moedas imediatas do sensível, são morfemas por meio dos quais podem ser descritas as desigualdades vetoriais que nos agitam e nos permitem "fazer um balanço" para, em meio à corrente por vezes precipitada dos afetos, saber "em que pé" estamos (p. 49,60).

O discurso, dessa maneira, dirige-se a uma plenitude ou a uma nulidade total, e o par mais e menos constitui as formas elementares de variabilidade tensiva. O mais e o menos podem funcionar de forma intransitiva, ou seja, apenas mais ou apenas menos; de forma transitiva: mais menos e menos mais; e, finalmente, de forma reflexiva: mais mais e menos menos. Cabe dizer que a forma reflexiva gera sintagmas falsamente redundantes, pois no caso do menos menos, por exemplo, não se diminui, mas se aumenta.

Assim, do menos para o mais, temos a ascendência, e do mais para o menos, a descendência. A descendência se dirige da plenitude para a nulidade, enquanto a ascendência, da nulidade para a plenitude. É digno de nota ainda que ascendência e descendência são tanto oponíveis quanto componíveis. Assim, de forma correlata ao plano de expressão da fala, a exemplo dos prosodemas ${ }^{45}$, no plano do conteúdo, por meio do par mais e menos, o discurso se constitui de "picos" e "vales", ou seja, de momentos mais ou menos intensos.

\footnotetext{
${ }^{45}$ Sobre a "prosodização" da semiótica, ver, por exemplo, (TATIT, 1997, p. 19).
} 
No caso da direção ascendente, estão as categorias de restabelecimento [cada vez menos menos] e recrudescimento [cada vez mais mais]. No caso da direção descendente, figuram as categorias de atenuação [cada vez menos mais] e de minimização [cada vez mais menos].

Cada categoria, por sua vez, subdivide-se em duas unidades. No que se refere à atenuação, são suas unidades a moderação e a diminuição. A diminuição, por sua vez, compõe-se de redução e extenuação. No caso do restabelecimento, tem-se a retomada e a progressão. Quanto ao recrudescimento, figuram as unidades ampliação e saturação.

Na tabela a seguir (ZILBERBERG, 2011a, p. 60), tais relações estão dispostas de forma esquemática:

\begin{tabular}{|c|c|c|c|c|}
\hline DIREÇÃ̃O & \multicolumn{4}{|c|}{ CATEGORIAS } \\
\hline \multirow{3}{*}{ DESCENDÊNCIA } & \multicolumn{2}{|c|}{$\begin{array}{c}\text { ATENUAÇ̃̃O } \\
\text { [cada vez menos mais] }\end{array}$} & \multicolumn{2}{|c|}{$\begin{array}{c}\text { MINIMIZAÇÃO } \\
\text { [cada vez mais menos }]\end{array}$} \\
\hline & \multicolumn{4}{|c|}{ UNIDADES } \\
\hline & $\begin{array}{l}\text { Moderação } \\
\approx \text { retirada de } \\
\text { pelo menos } \\
\text { um mais }\end{array}$ & $\begin{array}{l}\text { Diminuição } \\
\approx \text { retirada de } \\
\text { mais de um mais }\end{array}$ & $\begin{array}{c}\text { Redução } \\
\approx \text { acréscimo de } \\
\text { pelo menos um } \\
\text { menos }\end{array}$ & $\begin{array}{l}\text { Extenuação } \\
\approx \text { acréscimo de } \\
\text { mais de um } \\
\text { menos }\end{array}$ \\
\hline DIREÇ̃̃̃O & \multicolumn{4}{|c|}{ CATEGORIAS } \\
\hline \multirow{3}{*}{ ASCENDÊNCIA } & \multicolumn{2}{|c|}{$\begin{array}{l}\text { RESTABELECIMENTO } \\
\text { [cada vez menos menos] }\end{array}$} & \multicolumn{2}{|c|}{$\begin{array}{l}\text { RECRUDESCIMENTO } \\
\text { [cada vez mais mais }]\end{array}$} \\
\hline & \multicolumn{4}{|c|}{ UNIDADES } \\
\hline & $\begin{array}{l}\text { Retomada } \\
\approx \text { retirada de } \\
\text { pelo menos } \\
\text { um menos }\end{array}$ & $\begin{array}{l}\text { Progressão } \\
\approx \text { retirada de } \\
\text { mais de um } \\
\quad \text { menos }\end{array}$ & $\begin{array}{l}\text { Ampliação } \\
\approx \text { acréscimo de } \\
\text { pelo menos um } \\
\quad \text { mais }\end{array}$ & $\begin{array}{l}\text { Saturação } \\
\approx \text { acréscimo de } \\
\text { mais de um mais }\end{array}$ \\
\hline
\end{tabular}




\subsubsection{Tensividade}

Conforme dissemos, a afetividade (foria, estesia), pela ótica tensiva, torna-se categoria de primeira ordem, denominada intensidade. Esta rege, governa, a extensidade: os estados de coisas, o inteligível. Assim, a tensividade é o lugar imaginário em que a intensidade se une à extensidade. Poder-se-ia dizer ainda, em termos hjelmslevianos, que a tensividade é a função, enquanto intensidade e extensidade são os funtivos, ou, ainda, a tensividade é a categoria, enquanto a intensidade e a extensidade são os termos. Vejamos o seguinte esquema:

\section{TENSIVIDADE}

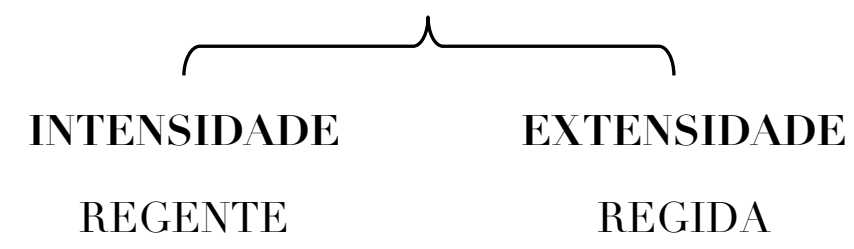

A junção do eixo da intensidade (sensível), na linha das ordenadas, e do eixo da extensidade (inteligível), na linha das abscissas, definem o espaço tensivo, que recebe e qualifica as grandezas que têm acesso ao campo de presença. O espaço tensivo é, dessa forma, nas palavras de Zilberberg (2011a, p. 253): "uma representação espacial cômoda dos estados e acontecimentos que surgem no campo de presença”. Vejamos o diagrama: 


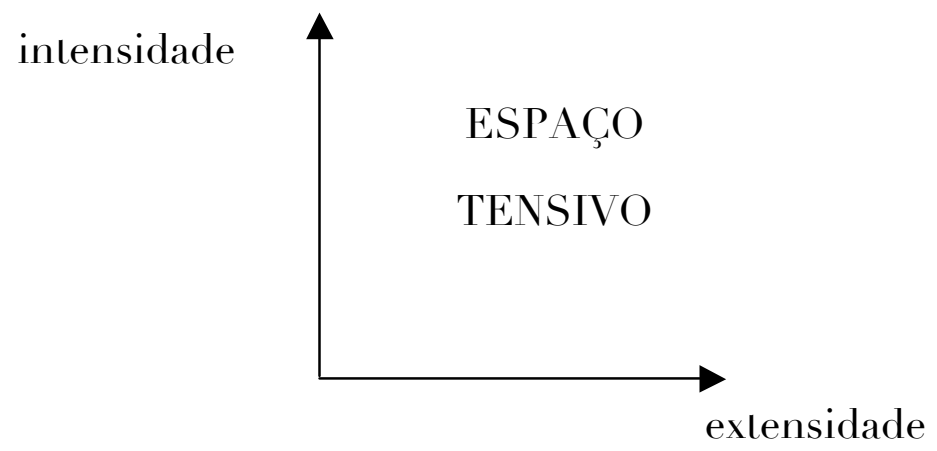

Esse espaço é necessariamente complexo, porquanto é produto da relação sine qua non dos estados de alma com os estados de coisas. Um fato semiótico, por sua vez, é condicionado - ou ainda, só tem existência semiótica - no e pelo espaço tensivo, o qual se produz, conforme dissemos, pela projeção da intensidade sobre a extensidade. Assim, qualquer ponto dentro do espaço tensivo corresponderá a um fato semiótico que, obrigatoriamente, terá uma valência em termos de intensidade e outra valência em termos de extensidade. Ainda segundo o autor, "um dos méritos do espaço tensivo, por mais rudimentar que seja, é o de obrigar-nos a investigar a amplitude, a velocidade e a duração dos devires" (ZILBERBERG, 2011a, p. 23).

O eixo da intensidade opera por meio dos pares [impactante os. tênue]; o eixo da extensidade, por sua vez, pelos pares [concentrado os. difuso]. Segundo Zilberberg (2011a, p. 67) são esses pares que controlam o acesso ao campo de presença. Assim, no que tange à intensidade, uma grandeza acessa o campo de presença de forma proporcional à quantidade de impacto que carrega consigo e, em termos de extensidade, ela será mais 
ou menos difusa, a partir das operações de mistura e triagem. No diagrama a seguir, temos a representação gráfica:

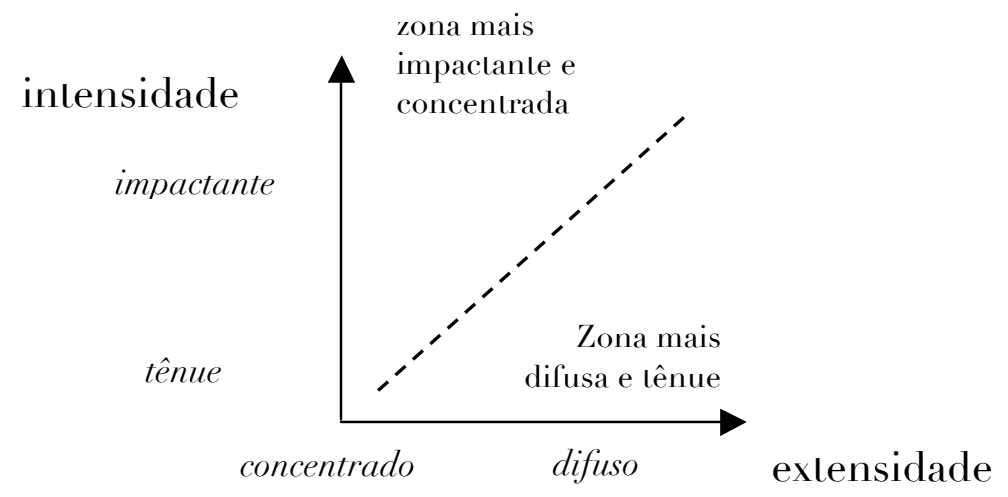

Cabe dizer que, quanto mais um fato semiótico tender à concentração, mais ele será guiado pelos valores de absoluto. Por outro lado, quanto mais esse fato tender à difusão, mais ele será governado pelos valores de universo. No caso dos valores de absoluto, entram em jogo as operações de triagem; no caso dos valores de universo, opera-se por mistura.

Zilberberg (2011a, p. 93), além disso, prevê dois tipos de correlação entre intensidade e extensidade. A primeira delas é a correlação conversa, na qual, quanto maior a intensidade, maior será a extensidade. Na correlação inversa, por sua vez, quando maior a intensidade, menor a extensidade e vice-versa. Nos gráficos a seguir, tais relações estão representadas: 


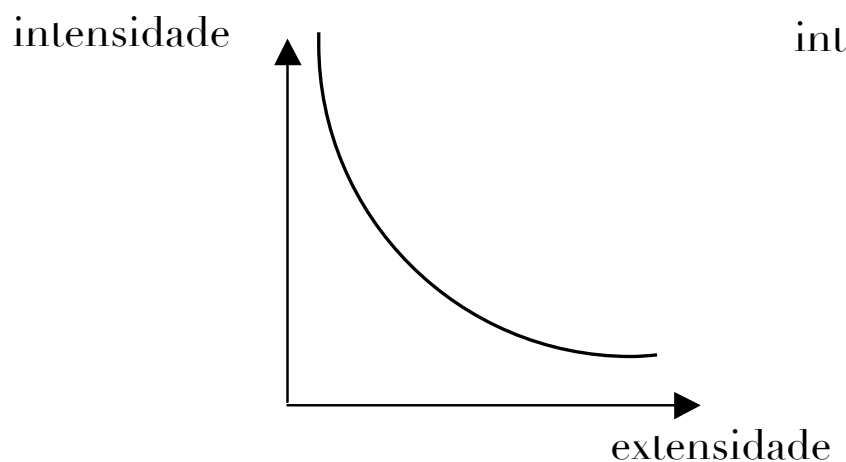

RELAÇÃO INVERSA intensidade

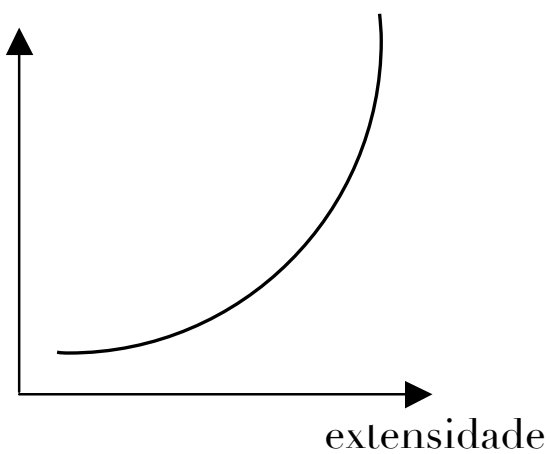

RELAÇÃO CONVERSA

\subsubsection{Dimensões e subdimensões}

Em Zilberberg (2011a, p. 69, 250), passa-se a denominar os eixos da intensidade e o da extensidade de "dimensões", ("valências", em Tensão $e$ significação) termo tomado, segundo o autor, da obra La catégorie des cas, de Hjelmslev. Cada dimensão comporta, por sua vez, duas subdimensões. A intensidade, assim, une andamento e tonicidade, enquanto a extensidade comporta temporalidade e espacialidade. O quadro a seguir representa tais esquizias:

\begin{tabular}{|c|c|c|c|c|}
\hline Dimensões & \multicolumn{2}{|c|}{ INTENSIDADE } & \multicolumn{2}{c|}{ EXTENSIDADE } \\
& \multicolumn{2}{|c|}{ (regente) } & \multicolumn{2}{c|}{ (regida) } \\
\hline Subdimensões & Andamento & Tonicidade & Temporalidade & Espacialidade \\
\hline
\end{tabular}


Tomemos, inicialmente, a dimensão da intensidade e suas duas respectivas subdimensões. $\mathrm{O}$ andamento se refere à velocidade com que um objeto adentra o campo de presença. Sua oposição básica é o [rápido os. lento]. A tonicidade, por sua vez, representa a força com que esse objeto penetra no campo de presença do sujeito, ou seja, de forma tônica ou átona.

Na dimensão da extensidade, unem-se temporalidade e espacialidade. A temporalidade se refere à percepção de duração dos eventos: o tempo do pervir é longo, ao passo que o tempo do sobrevir é breve. Da mesma forma como na temporalidade, na espacialidade há um ponto de vista subjetal a partir do qual o aberto se opõe ao fechado.

Se a dimensão da intensidade rege a sua contraparte, a extensidade, o mesmo é possível em relação às subdimensões. No quadro a seguir, baseado em Zilberberg (2011a, p. 72, 251), estão expostas as várias possibilidades de recção de uma subdimensão por outra e seus respectivos efeitos:

\begin{tabular}{|c|c|c|}
\hline $\begin{array}{c}\text { RECC,̃̃O DE UMA } \\
\text { SUBDIMENSÃO POR OUTRA }\end{array}$ & $\begin{array}{c}\text { TIPO DE } \\
\text { CORRELAÇÃO }\end{array}$ & EFEITO \\
\hline $\begin{array}{c}\text { Andamento } \rightarrow \text { Tonicidade } \\
\text { (pertencentes à mesma dimensão) }\end{array}$ & Conversa & Impacto \\
\hline Temporalidade $\rightarrow$ Espacialidade & Conversa & Universalidade \\
(pertencentes à mesma dimensão) & & Abreviamento \\
\hline Andamento $\rightarrow$ Temporalidade & Inversa & Profundidade \\
\hline pertencentes a dimensões distintas) & & Estreitamento \\
\hline Tonicidade $\rightarrow$ Espacialidade & Conversa & \\
\hline (pertencentes a dimensões distintas) & & \\
\hline Andamento $\rightarrow$ Espacialidade & Inversa & \\
\hline
\end{tabular}




\begin{tabular}{|c|c|c|}
\hline $\begin{array}{c}\text { Tonicidade } \rightarrow \text { Temporalidade } \\
\text { (pertencentes à mesma dimensão) }\end{array}$ & Conversa & Persistência \\
\hline
\end{tabular}

\subsubsection{Foremas}

Segundo Zilberberg (2011a, p. 72), são foremas, “a foria cifrada sob certo aspecto", os termos direção, posição e elã. Sobre essa base formal, são articulados os pares que compõem a intensidade (andamento e tonicidade) e os pares que compõem a extensidade (temporalidade e espacialidade). Segundo o autor, o termo elã é pressuposto, enquanto os termos direção e posição são pressuponentes. Dito de outro modo, estes dois últimos mantêm dependência em relação ao primeiro. Assim, concede-se ao elã uma primazia sobre os termos direção e posição pelo fato de o sofrer, pela ótica da tensividade, pressupor o agir, ou seja, porque a intensidade rege a extensidade. Se em Fontanille e Zilberberg (2001) o termo valência se referia aos eixos da intensidade e da extensidade, em Zilberberg (2011a), em sentido estrito, a valência é a intersecção de um forema com uma subdimensão.

Assim, o cruzamento de três foremas com quatro subdimensões produz 12 pares de valências, conforme Zilberberg (2011a, p. 74), da seguinte maneira: 


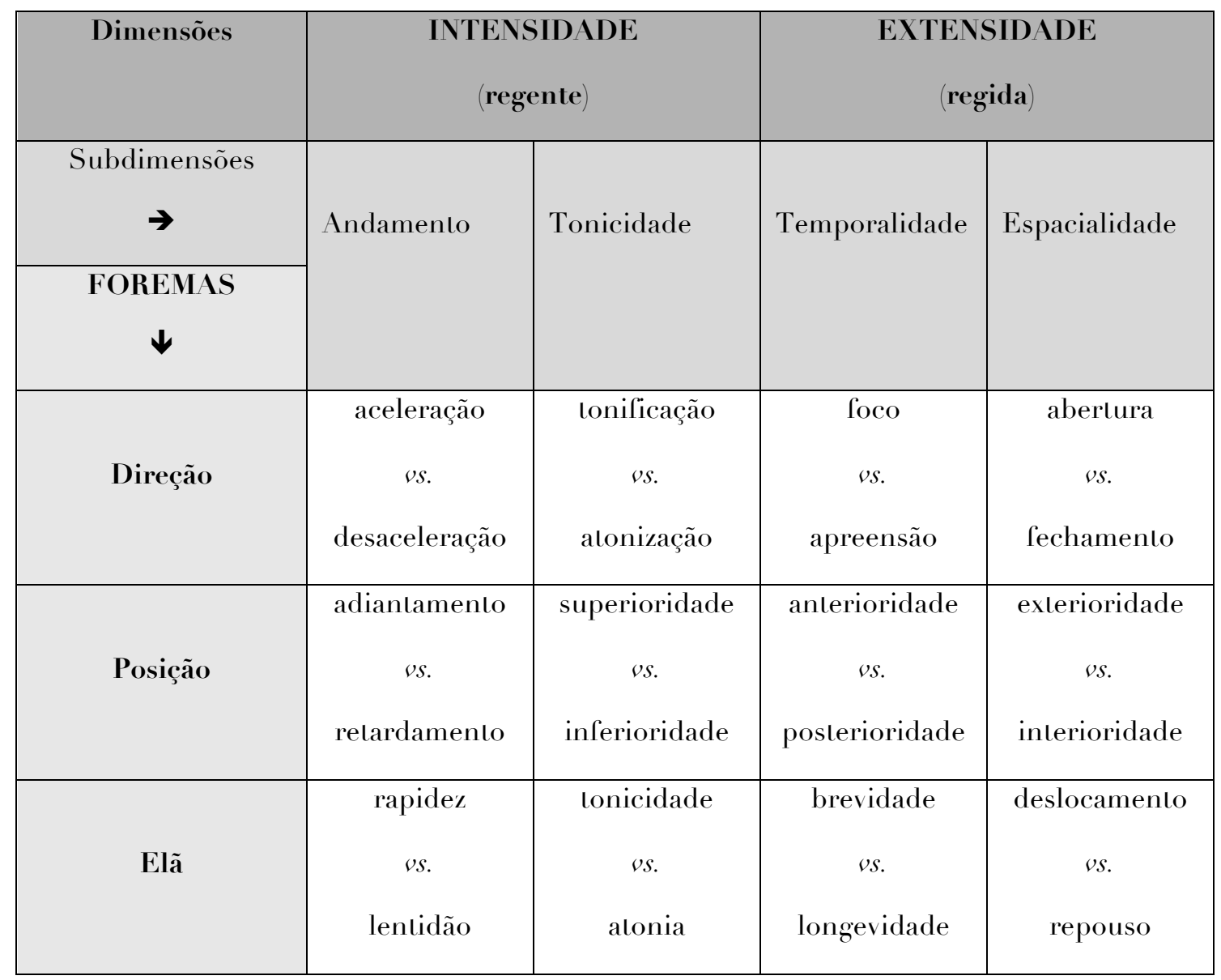

\subsection{SINTAXE E SEMÂNTICA TENSIVAS}

Assim como no percurso gerativo do sentido, em que cada patamar possui uma semântica e uma sintaxe, no que respeita ao nível tensivo, Zilberberg (2011b, p. 66) prevê três sintaxes e três semânticas.

A sintaxe intensiva funciona por meio de aumentos e diminuições no eixo da intensidade, a partir do par mais e menos. Ascendente é a direção ligada ao mais, e descendente, ao menos. A sintaxe extensiva, por sua vez, funciona através das operações de mistura e de triagem no eixo da extensidade: quanto maior for a tendência à difusão, mais estarão em jogo os 
valores de universo; quanto maior a tendência à triagem, mais os valores regentes serão os de absoluto. Por fim, a sintaxe juntiva leva em conta as operações de concessão e de implicação. Esta, segundo Fontanille e Zilberberg (2001, p. 237), "é uma alternativa à implicação quando a ligação entre a competência e a performance não é mais necessária, mas impossível ou contingente". Assim, a sintaxe juntiva reúne dois estilos discursivos: o implicativo, que se apoia numa lógica de pressuposição, e o concessivo, que se apoia numa lógica da ordem do imprevisto, isto é, quando a sobrevinda do acontecimento surpreende o sujeito semiótico de uma tal maneira que a ele só lhe resta a "tempestade modal" de que fala Zilberberg (2011a, p. 236), tema tratado na próxima seção.

Quanto à semântica tensiva, o autor, da mesma forma, dispõe os termos segundo a intensidade, a extensidade e a junção, e segundo as matrizes sobrecontrário átono, subcontrário átono, subcontrário tônico e sobrecontrário tônico. Assim, a semântica intensiva reúne os termos: nulo, tênue, forte, supremo. A semântica extensiva, por sua vez, compõe-se dos termos universal, comum, raro e exclusivo. A semântica juntiva, por fim, congrega os termos necessário, esperado, inesperado, surpreendente. A tabela a seguir, baseada em Zilberberg (2011b, p. 66), reúne, de forma esquemática, a sintaxe e a semântica tensivas: 


\begin{tabular}{|c|c|c|c|c|}
\hline $\begin{array}{c}\text { matriz } \rightarrow \\
\text { paradigma } \\
\downarrow\end{array}$ & $\begin{array}{l}\text { sobrecontrário } \\
\text { átono }\end{array}$ & $\begin{array}{l}\text { subcontrário } \\
\text { átono }\end{array}$ & $\begin{array}{l}\text { subcontrário } \\
\text { tônico }\end{array}$ & $\begin{array}{c}\text { sobrecontrário } \\
\text { tônico }\end{array}$ \\
\hline $\begin{array}{l}\text { semântica } \\
\text { intensiva }\end{array}$ & nulo & tênue & forte & supremo \\
\hline $\begin{array}{l}\text { sintaxe } \\
\text { intensiva }\end{array}$ & \multicolumn{2}{|c|}{ diminuição } & \multicolumn{2}{|c|}{ aumento } \\
\hline $\begin{array}{l}\text { semântica } \\
\text { extensiva }\end{array}$ & universal & comum & raro & exclusivo \\
\hline $\begin{array}{c}\text { sintaxe } \\
\text { extensiva }\end{array}$ & \multicolumn{2}{|c|}{ mistura } & \multicolumn{2}{|c|}{ triagem } \\
\hline $\begin{array}{l}\text { semântica } \\
\text { juntiva }\end{array}$ & necessário & esperado & inesperado & surpreendente \\
\hline $\begin{array}{l}\text { sintaxe } \\
\text { juntiva }\end{array}$ & \multicolumn{2}{|c|}{ implicação } & \multicolumn{2}{|c|}{ concessão } \\
\hline
\end{tabular}

\subsection{ESTILOS DISCURSIVOS: acontecimento e exercício}

Dizem Fontanille e Zilberberg (2001, p. 237):

A forma implicativa é talvez a mais estudada, mas também menos propícia a manter a atenção de um narratário, na medida em que a força da ligação de necessidade cria, numa área cultural determinada, uma espera e uma previsão muito premente.

O estilo discursivo a que se referem os autores está diretamente ligado à noção de narratividade que, por muito tempo, foi o principal ponto de interesse da semiótica. Atualmente, entretanto, a emergência de estudos 
que levam em conta o aspecto sensível, os eventos fortuitos, trazem à tona um outro ponto de vista que privilegia outro estilo discursivo: o acontecimento, regido pela concessão. Com efeito, afirma Zilberberg (2007, p. 16): "Seria incompreensível que a semiótica continuasse a agir como se o acontecimento não existisse". Por catálise, depreende-se da citação que se a "forma implicativa é a menos propicia a manter a atenção do narratário", a forma concessiva - a do acontecimento - ao contrário, consegue cooptar de forma mais intensa e duradoura seu interesse.

Em Zilberberg (2007, p. 25), o autor estabelece três modos eficiência, existência e junção - cujos respectivos termos configuram os estilos discursivos a que faz alusão o título desta seção: o acontecimento e o exercício.

O modo de eficiência designa "a maneira pela qual uma grandeza se instala num campo de presença” (ZILBERBERG, 2007, p. 18). Se a grandeza se instala lentamente, configura-se a modalidade do pervir. Se, ao contrário, penetra abruptamente, tem-se a modalidade do sobrevir. O modo de existência, por sua vez, refere-se à alternância entre os pares foco $\mathrm{e}$ apreensão. Tais termos se referem ao correlato subjetal dos termos pervir e sobrevir. No caso do foco, há um sujeito operador que age, muito próximo ao sujeito do fazer; não há surpresas, mas relações pressupostas tais como no esquema narrativo. Na apreensão ocorre o contrário; não se trata mais de um sujeito do fazer, mas um sujeito do estado que sofre, que suporta, que, enfim, é invadido pelo objeto que surge ex abrupto. O modo juntivo, por sua vez, coincide com a sintaxe juntiva vista na seção anterior, e articula o modo implicativo e o modo concessivo:

No caso da implicação, o direito e o fato se respaldam mutuamente. Sua esfera é a da implicação: "se a, então b" e 
geralmente da causalidade legal. [...] No caso da concessão, o direito e o fato estão em discordância um do outro. Ela tem como emblema a dupla formada pelo embora e pelo entretanto: "embora a, entretanto não b" (ZILBERBERG, 2007, p. 23).

Para o autor (ZILBERBERG, 2007, p. 25), o estilo discursivo do acontecimento se define estruturalmente a partir de cada um dos pares dos modos de eficiência, de existência e de junção, a saber: o sobrevir, a apreensão e a concessão. O estilo discursivo do exercício, por sua vez, tem sua estrutura composta dos termos pervir, foco e implicação, a partir dos modos já mencionados. A seguir, apresentamos de forma esquemática a estrutura do acontecimento e do exercício:

\begin{tabular}{|c|c|c|}
\hline $\begin{array}{c}\text { determinados } \rightarrow \\
\text { determinantes } \\
\downarrow\end{array}$ & ACONTECIMENTO & \\
\hline modo de eficiência & sobrevir & pervir \\
\hline modo de existência & apreensão & foco \\
\hline modo de junção & concessão & implicação \\
\hline
\end{tabular}

Acontecimento e exercício são, pois, duas grandes orientações discursivas. A primeira corresponderia à problemática do surpreendente, do inesperado, regido por uma lógica concessiva. A segunda, por sua vez, à questão da narratividade que, por anos, foi o principal foco de interesse da semiótica, a qual, por sua vez, é governada pela lógica implicativa. Com efeito, para Zilberberg (2011a, p. 171) o acontecimento e o esquema 
narrativo canônico são duas grandes vias possíveis de sentido. São, em suma, duas perspectivas discursivas:

A narratividade, que o acontecimento virtualizou, reclama seus direitos, em compreensão ou em explicação, conforme o estilo persuasivo vigente. De que modo? Considerando o acontecimento como o ponto de chegada cuja origem não é imediatamente identificável (ZILBERBERG, 2011a, p. 190).

Assim, pode-se dizer que, pela ótica da tensividade, a narrativa corresponderia ao discurso do exercício, enquanto o acontecimento, para esta última, à performance cujas fases anteriormente pressupostas estão virtualizadas.

\subsection{SINTAXE DO ACONTECIMENTO}

Tendo sido introduzidos alguns elementos da gramática tensiva, detenhamo-nos naquilo que se considera o seu cerne: o acontecimento [événement]. Zilberberg (2011a, p. 46) chega mesmo a designar a semiótica tensiva como uma semiótica do acontecimento, ao afirmar: "ao lado de uma semiótica fascinada ou talvez até alienada pela produção, apropriação e circulação dos objetos de valor, está se delineando uma não menos consistente semiótica do acontecimento".

Assim, cumpre, de início, diferenciar "fato" de "acontecimento": "o fato tem por correlato intenso o acontecimento. [...] O acontecimento é o correlato hiperbólico do fato, do mesmo modo como o fato se inscreve como diminutivo do acontecimento" (ZILBERBERG, 2007, p. 16). O acontecimento, dessa forma, é raro ao passo que o fato é numeroso. Ademais, o acontecimento concentra uma carga tímica paroxística. Este também se 
caracteriza por não poder ser visado, antecipado, pois, "quando a coisa acontece, já é tarde demais!" (ZILBERBERG, 2011, p. 169)

A sintaxe do acontecimento é definida como o produto das subvalências paroxísticas andamento e tonicidade. Em termos simples e breves, é o produto da velocidade aguda de um evento com sua energia e força de impacto no sujeito. Essas subdimensões da intensidade agem juntas, perturbando o sujeito por meio de uma "tempestade modal” (ZILBERBERG, 2011a, p. 236) instantânea, deixando-lhe apenas um sofrer que se sobrepõe ao agir: "O acontecimento, por ser portador do impacto, manifesta enquanto tal que o sujeito trocou 'a contragosto' o universo da medida pelo da desmedida" (p. 163). Noutros termos, o acontecimento significa levar a afetividade ao auge, e tornar a legibilidade, a intelecção, nula.

Quanto às subdimensões da extensidade, a temporalidade é aniquilada - o tempo fica "fora dos eixos". O mesmo se pode dizer da espacialidade, pois o sujeito, estupefato, vê-se "pregado" no chão, ou, num lapso de tempo, engolido por um buraco negro, retirado de sua própria ambiência:

$\mathrm{O}$ acontecimento, na qualidade de grandeza tensiva, deve ser apreendido como uma inversão das valências respectivas do sensível e do inteligível. Marcado por um andamento rápido demais para o sujeito, o acontecimento leva o sensível à incandescência e o inteligível à nulidade (ZILBERBERG, 2011, p. 190).

No diagrama a seguir, representa-se graficamente o acontecimento, na parte superior esquerda do espaço tensivo, e o exercício, na porção inferior direita: 


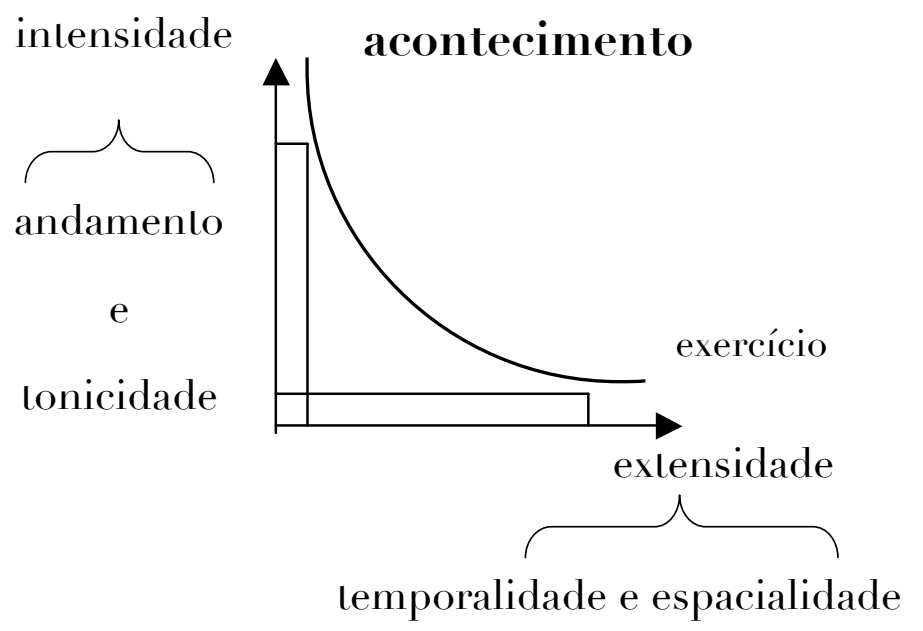

A hipótese de acontecimento para Zilberberg é, assim, a "realização súbita e extática do irrealizável” (2011, p. 176), mais precisamente, esse sistema levaria em conta o modo concessivo, oposto ao implicativo a que já nos referimos, segundo o qual: ainda que não fosse possível, tal coisa aconteceu.

Agindo contra esse programa, o discurso atuaria como um contraprograma, uma espécie de frenagem do andamento acelerado, isto é, uma intelecção do que é essencialmente sensível: "O discurso se empenha em refazer aquilo que a exclamação desfez" (ZILBERBERG, 2011a, p. 194). Ou, ainda: "O acontecimento significa literalmente a negação do dizer, a negação do discurso. [...] O acontecimento é antes de tudo um não-sei-o-quê que deixa o sujeito sem voz, sem a sua voz" (ZILBERBERG, 2011a, p. 189). Por isso, o discurso depende do acontecimento e do fato para existir. Ele se constrói justamente pela sucessão de continuidades de descontinuidades, o 
que justifica a existência de um programa de frenagem a que o semioticista se referiu.

Cumpre afirmar também que o acontecimento satura o campo de presença, por isso, nas palavras que Zilberberg (2011a, p. 192) empresta de Tocqueville, "prescinde de significação, mas apenas momentaneamente”. Porém, seu destino inexorável é perder em intensidade e ganhar em extensidade. Assim, “o sujeito consegue progressivamente, por si próprio ou com auxílio, reconfigurar o conteúdo semântico do acontecimento em estado" (ZILBERBERG, 2011a, p. 168). Em suma:

O acontecimento não pode ser apreendido senão como algo afetante, perturbador, que suspende momentaneamente o curso do tempo. Mas nada nem ninguém conseguiria impedir que o tempo logo retome seu curso e que o acontecimento entre pouco a pouco nas vias da potencialização, isto é, primeiramente, na memória, depois, com o tempo na história, de maneira que, grosso modo, tal acontecimento ganhe em legibilidade, em inteligibilidade, o que perde paulatinamente em agudeza (ZILBERBERG, 2011a, p. 169).

\section{7 ACONTECIMENTO E JORNALISMO}

Afirma Zilberberg (2011a, p. 190): "Do ponto de vista teórico parecenos que a relação estrutural entre o discurso e o acontecimento procede da catálise". Dito de outro modo, ao acontecimento, à não voz aludida pelo semioticista, seguir-se-ia um programa de frenagem, de intelecção. A exclamação, o limiar do discurso, seria atenuada pelo próprio discurso, para que o sensível perca em intensidade e possa dar lugar ao inteligível, ao 
discurso. Assim, para Zilberberg (2011a, p. 194), o discurso sucede o acontecimento, "[que] rompe o próprio desenrolar do discurso: este não é um objeto, mas uma atividade”. Pensar a relação entre discurso e acontecimento como uma atividade nos permite percebê-la como uma estrutura elástica, em constante movimento.

No âmbito do jornalismo, poder-se-ia dizer que o mesmo se passa. Ele precisa de fatos e acontecimentos para existir. Estes são, pois, sua molamestra. Entretanto, não são quaisquer fatos que estampam as páginas dos jornais, que figuram nos telejornais ou nos portais noticiosos da internet, já que seria impossível cobrir todas as ocorrências mundanas. Em teorias do jornalismo, fala-se em critérios de noticiabilidade, ou seja, uma operação de triagem que define o que entrará ou não no campo de presença do sujeito semiótico (enunciatário), ou seja, o que será ou não publicado.

Para Sodré (2009, p. 74), tais critérios baseiam-se no "valor-notícia" que um fato possui. Quer dizer, quanto maior o valor-notícia, maior a possibilidade de um fato ser noticiado. O valor-notícia, para o autor (2009, p. 74), define-se como uma "marcação", no sentido fonológico-estrutural da expressão ${ }^{46}$ :

O termo marcado apresenta no quadro de uma determinada cultura, um desenvolvimento mais complexo - tornando-se por isso suporte de uma carga maior de valoração simbólica - do que o não-marcado. Assim, o que chamamos de

\footnotetext{
46 “As oposições privativas são aquelas nas quais um dos termos da oposição é caracterizado pela existência de uma marca, o outro pela ausência dessa marca: por ex.: "sonoro" "surdo", "nasalidade" - "não nasalidade", "arredondado" - "não arredondado". O termo de oposição caracterizado pela presença da marca será chamado de "termo marcado" e aquele caracterizado pela ausência da marca, "termo não marcado". Esse tipo de oposição para a fonologia é de extrema importância" (TRUBETZKOY, 2005 [1938], p. 77).
} 
acontecimento jornalístico é um fato marcado, portanto, mais determinado para o sistema da informação pública do que outros existentes tidos como não-marcados [...]. A marcação define a noticiabilidade de um fato por critérios, concebidos como valores adequados ao acontecimento: os salores-notícia (SODRÉ, 2009, p. 75)

Por outro lado, afirma Sodré (2009, p. 73) que “a redundância do esperado seria, assim, o grau zero do valor-notícia”.

Zilberberg (2011a, p. 244) nos permite operacionalizar, sob a ótica da tensividade, o conceito de valor-notícia, ao discorrer sobre o modo implicativo e o modo concessivo. O semioticista francês utiliza o termo "marcado" para designar o acontecimento (concessão) - marcado por ser mais raro - e o termo "não marcado" para nomear a regra (implicação). Cabe dizer que o uso que cada autor faz desses termos, no que tange à obra de cada um e no que respeita a nossos interesses, não configura mera coincidência. Assim, tanto para Sodré (2009) quanto para Zilberberg (2011a), a marca se refere a um traço/raro/ que distingue um elemento de outro.

Vejamos o seguinte diagrama reproduzido de Zilberberg (2011a, p. 244):

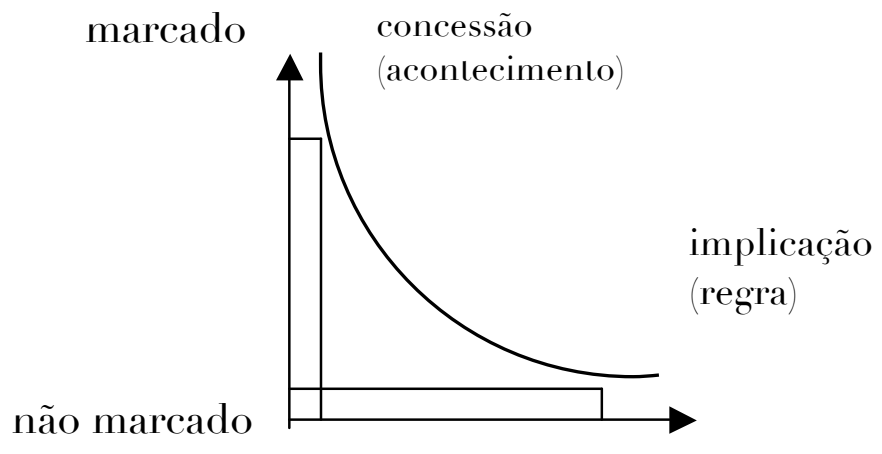


Pela perspectiva tensiva, o "valor-notícia" a que se refere Sodré (2009) comporta um traço concessivo em maior ou menor grau. O grau máximo é, decerto, o fait divers, o qual, para o autor, possui um maior "potencial de aguçamento da percepção do leitor" (2009, p. 78), uma maior carga de intensidade, dir-se-ia pela perspectiva tensiva.

O diagrama anterior é heurístico no sentido de semiotizar a noção de valor-notícia a partir de uma perspectiva gradiente que oscila entre os termos marcado e não marcado, ligados à concessão e à implicação, respectivamente. Por conseguinte, se, por um lado, of fait divers, geralmente, apresenta um alto grau de intensidade e baixo de extensidade, por outro, na correlação de uma posição intermediária dos dois eixos, estão, por exemplo, competições esportivas, entrevistas políticas ou coberturas de grandes cerimônias oficiais. Com um grau mínimo de intensidade e máximo de extensidade estariam os elementos cujo efeito de surpresa é mínimo: editorial, espaço reservado à opinião de leitores, horóscopo, crônicas, receitas culinárias, serviços, etc.

Por isso, mais uma vez fazendo alusão ao diagrama anterior, uma constante tensão entre o esperado, a regra, e o inesperado, o acontecimento, define, pois, o jornalismo. Acerca dessa tensão, Landowski (1992, p. 120) assevera:

A narrativa jornalística valoriza, por princípio, a irrupção do inesperado, do singular, do a-normal, para depois tornar a situar o sensacional no fio de uma História que lhe dá seu sentido e o traz de volta à norma, à ordem das coisas previsíveis - ou seja, ao "cotidiano", que, no entanto, lhe é, $a$ priori, como que a antítese. [...] Com efeito, o jornal também fala do banal, do esperado, do trivial [...]: rubricas de informações práticas, crônicas, correspondências dos próprios leitores, classificados e anúncios de todo o tipo. 
Dessa maneira, embora o texto jornalístico vise sempre ao acontecimento, ao extraordinário, ou, no jargão jornalístico, ao "furo de reportagem", "[que] atrai todas as atenções porque é escasso, valioso, ostensivo e simbólico" (BONNER, 2009, p. 14), o rotineiro, inevitavelmente, também é incluído. A razão disso deve-se ao fato de o acontecimento ser raro, enquanto o fato (com menor carga tímica) ser numeroso (Cf. ZILBERBERG, 2007). E, afinal de contas, o jornal, televisionado, impresso ou digital, é modalizado por um dever-ser implacável, que, diariamente, levao a ser publicado ou televisionado.

Encontramos, ainda, ressonância sobre o caráter ambivalente do jornal, isto é, que une o esperado e o inesperado, nas palavras de Gomes (2012, p. 11, 2012):

A narrativa jornalística $[. .$.$] caracteriza-se, ao mesmo tempo,$ pela ocorrência tanto do acontecimento, do fato excepcional, do "furo" de reportagem, do surpreendente, quanto do esperado, do fato corriqueiro e familiar, do serviço de utilidade pública. O texto jornalístico pode, ainda, não só enfatizar os eventos em seu desenrolar implicativo, as etapas das ações representadas mediante suas correlações lógicas, suas relações de causa e efeito, mas também capturar a atenção do leitor destacando os aspectos inusitados de uma relação concessiva entre fatos improváveis, inconciliáveis e aparentemente incompatíveis, mas que, afinal, acontecem.

Assim, uma visada semiótica sobre o campo do jornalismo, através do conceito de concessão, permite-nos, pois, posicionar o fait divers como a notícia concessiva por excelência. No próximo capítulo, temos a oportunidade de percorrer os mecanismos discursivos desse tipo de relato jornalístico, com o fito de perceber - devido ou malgrado sua carga tímica elevada - o que o faz durar, ou, pelo contrário, fenecer. A partir das análises 
que se apresentam a seguir, visamos a responder a essa e a outras questões apresentadas na Introdução desta tese. 
3

\section{[Análises: tensividade e faits divers]}

"A concessão dramatiza a veridicção." Claude Zilberberg

"Ce qui nous frappe, persiste et se projette sur les choses suivantes. L'intense a donc une qualité propre - qui est de persister au delà de la durée de sa cause."

Paul Valéry 


\subsection{INTRODUÇÃ̃ À ANÁLISE}

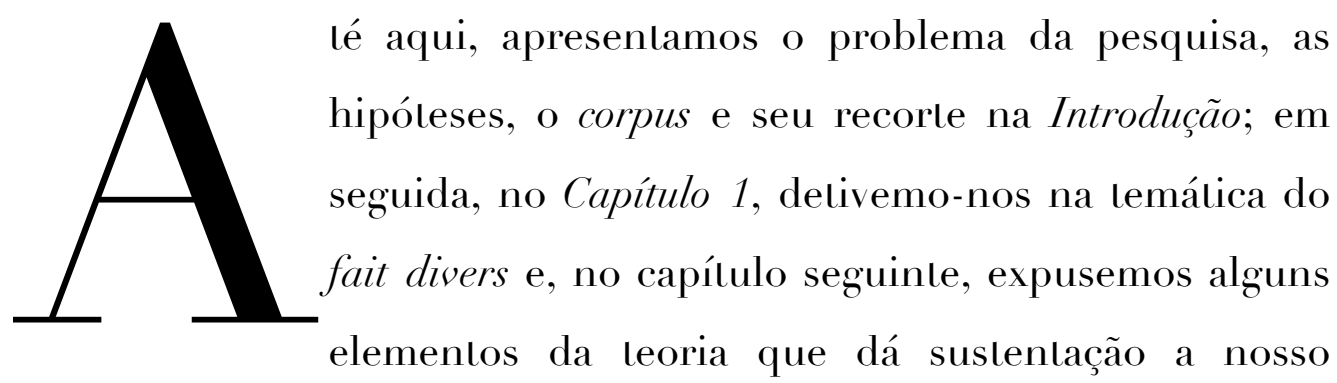
estudo: a semiótica tensiva. O presente capítulo, assim, empreende as análises do corpus a partir dessa perspectiva.

Inicialmente, examinamos a cobertura do Caso Isabella Nardoni feita pelo Jornal Nacional. Ratificamos que a escolha de uma análise mais detalhada desse caso se deveu àquilo que ele tem de raro, ou seja, no que se refere à sua duração, mas também não podemos esquecer que ocorrências como essa são representativas de inúmeros outros fatos que obtiveram considerável repercussão nos meios de comunicação.

Em seguida, examinamos outros faits divers, que se assemelham pela temática ou pela longa duração, ou, ao contrário, diferem-se por elementos opostos/distintos. Ancorando-nos nas análises deste capítulo e no arcabouço teórico exposto, propomos, no Capítulo 4, uma abordagem tensiva do fait divers. 


\subsection{COBERTURA DO CASO ISABELLA NARDONI PELO JORNAL NACIONAL}

Para analisar a cobertura do Caso Isabella Nardoni, como pertencente à categoria englobante fait divers, dividimos nosso estudo em alguns eixos analíticos. Estabelecer perspectivas conceituais permite-nos, pois, realizar um exame do corpus marcado por um maior grau de organização, que, por conseguinte, possibilita-nos observar com mais nitidez as (in)variantes que subjazem ao fait divers.

Para tal, consideramos os seguintes eixos: concessão e fidúcia, duração e intensidade, a paixão coletiva da comoção e, por fim, relações intertextuais e interdiscursivas que o texto em análise permite estabelecer com outros textos/discursos. Cumpre dizer, ademais, que os eixos analíticos citados guiam-se pela perspectiva da tensividade.

As linhas de análise a que fizemos referência têm o objetivo de oferecer possíveis respostas à questão teórica deste trabalho, ou seja, buscar nos mecanismos do discurso as estratégias usadas pelo enunciador "Jornal Nacional" para "extensivizar" a intensidade do fait divers em questão, cuja estrutura, a priori, seria muito intensa, mas pouco extensa. A partir desse percurso analítico, procuramos recuperar, por catálise, o sujeito semiótico em cujo campo de presença irrompe o fait divers, ou seja, um enunciatário “telespectador" sensível às oscilações tensivas desse relato.

Antes de procedermos à análise, uma observação: embora tenhamos, no capítulo anterior, apresentado um panorama da semiótica tensiva, fazemos referência a outros conceitos e textos ainda não mencionados tanto da semiótica narrativa e discursiva quanto de seus desdobramentos 
atuais - sempre que se fizerem necessários. Afinal, se a tensividade é o substrato dos níveis mais concretos e complexos, os movimentos e conversões entre eles não se fazem sem que haja eco tanto nos patamares mais discretos quanto naquele do descontínuo, da presença e do afeto.

\subsubsection{Concessão e fidúcia}

Na presente subseção, analisamos o corpus através da relação entre fidúcia e concessão. Por isso, cumpre apresentar brevemente tais conceitos para, então, relacioná-los. Em relação àquele, conceito-chave da teoria semiótica, ancoramo-nos num texto de Greimas (1983, p. 103-113) - Le contrat de véridiction - cuja atualidade demonstra-se patente. No que respeita à concessão e sua relação com a fidúcia, recorremos sobretudo a Zilberberg (2011a).

Comecemos pela fidúcia. Para Greimas (1983, p. 105):

O discurso é esse lugar frágil onde se inscrevem e se leem a verdade, a falsidade, a mentira e o segredo; tais modos de veridicção resultam da relação entre enunciador $\mathrm{e}$ enunciatário, cujas diferentes posições não se fixam senão sob a forma de um equilíbrio mais ou menos estável procedentes de um acordo implícito entre os actantes da estrutura da comunicação. Este acordo tácito é denominado contrato de veridicção.

Desse modo, no escopo da semiótica, o discurso é o lugar de sua própria veridicção e, nela e por ela, criam-se efeitos de verdadeiro, falso, mentiroso ou secreto. Tais efeitos têm seus referentes inscritos na própria linguagem e não no mundo extralinguístico: “Já não se supõe que o sujeito 
da enunciação produza um discurso verdadeiro, mas um discurso que produza um efeito de sentido "verdade"” (GREIMAS, 1983, p. 109). Portanto, a verdade não é mais que um efeito discursivo, cuja modalização corresponderia mais a um fazer-parecer-verdadeiro, um fazer-persuasivo, que a ser-serdadeiro "em si".

Segundo o semioticista lituano, a veridicção, diferente da verossimilhança, não se relaciona com a adequação ao referente extralinguístico, mas com a adesão do destinatário. Por tal razão, a construção do simulacro de verdade está condicionada, não apenas pelo universo de crenças e valores do destinatário, mas pela representação que este último faz de seu destinador. Assim, a adesão, o crer, do destinatário à "verdade" do destinador é o que sanciona o contrato veridictório. Dessa forma, para Greimas (1983, p. 111): "Na epistemologia de nossos dias, o conceito de verdade é substituído, cada vez mais, pelo de eficácia". Por conseguinte, ainda que tal contrato se apoie num fazer cognitivo, da ordem do saber, ele é de natureza fiduciária, pertencente à esfera do crer $^{47}$.

No âmbito do jornalismo, o contrato fiduciário, ou, nos termos das teorias desse campo, a “credibilidade”, é, segundo Sodré (2009, p. 42), “[a] pedra de toque das relações entre o público e o jornal e, portanto, o principal capital simbólico do jornalista, e decorre de um pacto implícito entre o profissional da informação e o leitor". Porém, como se viu, pela perspectiva semiótica, tal contrato baseia-se fundamentalmente num fazer-

\footnotetext{
${ }^{47}$ Muito embora, ambas as modalidades, o saber e o $\mathrm{crer}$, sejam consideradas por Greimas (1983, p. 115-133) pertencentes a um mesmo universo cognitivo: "É como se o crer e o saber estivessem motivados por uma estrutura elástica que, em um momento de tensão extrema, produzisse, ao polarizar-se, uma oposição categórica, mas que, ao relaxar-se, ambos os termos chegassem a se confundir" (p. 116).
} 
parecer-verdadeiro, isto é, num fazer-persuasivo que será ou não sancionado pelo fazer-interpretativo do destinatário da comunicação.

Por isso, semioticamente, a questão da "verdade em si” é substituída pela da veridicção. Nesse sentido, é contundente a seguinte fala de Greimas (1983, p. 109): “Já que não há uma linguagem da verdade, não pode haver linguagem da ficção; já não há discurso literário, posto que tudo é literatura”. Assim, no que concerne a nosso ponto de vista sobre a problemática da "verdade", assumimos tal postulado segundo o qual o que está fundamentalmente em jogo é a eficiência do destinador em persuadir seu destinatário, de fazê-lo crer.

Ainda de acordo com Greimas (1983, p. 116), Georges Dumézil apontou que ao verbo latino credere subjazem hoje em dia, separadamente, os termos "crença" e "confiança". Fontanille e Zilberberg (2001, p. 264-265) operacionalizam essa relação, sob a égide da fidúcia:

\section{Fidúcia}

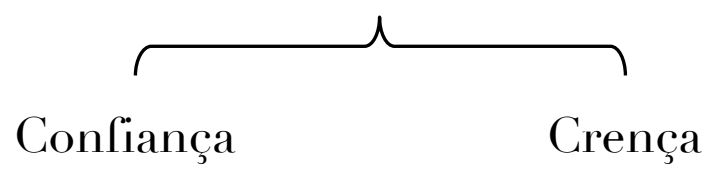

Segundo esses autores, a crença se estabelece entre um sujeito e um objeto, enquanto a confiança configura-se como uma relação intersubjetiva. De acordo ainda com os semioticistas (FONTANILLE; ZILBERBERG, 2001, p. 277), crises fiduciárias relacionam-se intimamente com o universo das 
paixões, o que nos permite dizer que operam, no nível tensivo, por aumentos e diminuições no eixo da intensidade.

Tendo discorrido sobre o conceito de fidúcia, cumpre relacioná-lo com o de concessão, já apresentado de forma pormenorizada no capítulo anterior.

A dimensão fiduciária tem o crer como o verbo-pivô, do qual se depreende o par crer us. não crer. Assim, o objeto do crer é o acreditável, ao passo que o objeto do não crer é o inacreditável. Zilberberg (2011a, p. 243244) opõe, do mesmo modo, o par acreditável os. inacreditável, sendo que o primeiro termo corresponde a alguma doxa, enquanto o segundo se afasta dela. Desse modo, crer no acreditável corresponde a uma operação implicativa, da mesma forma que não crer no inacreditável. Entretanto, salienta-se que são operações concessivas crer no inacreditável e não crer no acreditável.

Retomemos, agora, a sugestiva asserção de Zilberberg (2011, p. 66), que abriu como epígrafe este capítulo, segundo a qual, “a concessão dramatiza a veridicção".

Para o Houaiss, uma das acepções de "dramatizar", a que melhor se ajusta a este caso, é: "tornar (fato, situação, estado, sofrimento etc.) interessante e comovente como um drama, apresentando-o sob aspecto trágico ou dramático, ou evocando-o com cores mais vivas do que as que tinha ou tem". A concessão atua, assim, à maneira da hipotipose, carregando nas tintas, tornando mais intenso, sensorial, estésico o caráter da veridicção. Nesses termos, a concessão eleva a veridicção a seu ápice, intensificando-a. Assim, "crer no inacreditável" conduz à figura do sujeito do estupor, do espanto. Assim, quando se trata da relação entre a dimensão fiduciária - o 
crer - e o modo concessivo, o discurso, por meio da sintaxe intensiva com seus aumentos, tende à saturação.

Conforme demonstrado por este pequeno preâmbulo que antecede a análise, a relação entre fidúcia e concessão apresenta um forte poder heurístico para analisar a cobertura realizada pelo Jornal Nacional sobre o Caso Isabella Nardoni. Vejamos, pois, como isso se verifica.

\subsubsection{Análise I}

"Menina morre ao cair de prédio" é o título da primeira reportagem televisionada ${ }^{48}$ pelo Jornal Nacional, em 31/03/2008, sobre o Caso Isabella Nardoni, cuja cabeça ${ }^{49}$ é:

Isabela [sic], de cinco anos, caiu do sexto andar de um prédio em São Paulo no fím de semana e foi enterrada nesta segunda. Segundo a polícia ela teria sido jogada por alguém. O pai da criança, a mulher dele e alguns vizinhos prestaram depoimentos.

O trecho anterior noticia um fato inesperado; afinal, não é sempre que meninas de cinco anos são vítimas fatais de quedas de edifício. É claramente um fait divers pela perspectiva de Barthes (1964, p. 194): "uma informação monstruosa", da ordem do inusitado, do privado, do familiar.

\footnotetext{
${ }^{48}$ Reiteramos que as reportagens sobre o Caso Isabella Nardoni foram transcritas do site do Jornal Nacional (http:/g1.globo.com/jornal-nacional/), de onde também obtiveram-se os vídeos, com igual conteúdo e teor, dos quais são exibidos quadros (frames).

49 “Texto lido pelo apresentador para chamar a matéria [o qual] contém as informações mais relevantes da reportagem que será mostrada a seguir." (BISTANE; BACELLAR, 2010, p. 132; itálicos nossos), correlato ao lead do jornal impresso (Cf. REZENDE, 2000, p. 153). Segundo Bonner (2009, p. 88), o termo provavelmente deriva da expressão inglesa headline.
} 
Pela aproximação entre estrutura barthesiana do fait divers e a semiótica tensiva, empreendida no Capítulo 1, as bases concessivas do Caso Isabella Nardoni já se evidenciam desde a primeira reportagem. Informa-se que "ela teria sido jogada por alguém”. Um fragmento da reportagem detalha:

A polícia não tem dúvidas de que Isabela [sic] foi jogada do sexto andar de um prédio, no sábado à noite. A tela de proteção da janela foi cortada e o retalho ficou no apartamento. [...] Os policiais encontraram vestígio de sangue entre os quartos e a porta da sala.

Segundo o texto, não se trata de um acidente, mas, muito provavelmente, de um crime: "ela teria sido jogada por alguém". Aqui, o uso do condicional cria um efeito de hipótese e de não comprometimento por parte do noticiário; o enunciador é, pois, modalizado por um crer-ser.

A reportagem traz ainda a versão do pai de Isabella, Alexandre Nardoni, sobre o episódio da morte da filha:

\begin{abstract}
Alexandre contou à polícia que voltou para a casa com a família, depois de visitar a sogra. Disse que, primeiro, subiu com Isabela [sic]. Acendeu a luz do abajur do quarto dela e deixou a menina dormindo. Depois, trancou a porta do apartamento e voltou à garagem para ajudar a mulher, que estava no carro com os dois filhos pequenos. Contou que, ao entrar em casa, a luz do quarto estava acesa. Chegou a pensar que a menina tivesse caído da cama. Disse que, em seguida, notou a rede de proteção da janela cortada. Aí, viu o corpo de Isabela [sic] no jardim do prédio. Só quando os peritos entraram no apartamento, perceberam que era a tela do outro quarto que estava cortada. Isabela [sic] caiu do quarto dos irmãos.
\end{abstract}

A reportagem, entretanto, narra ainda que: 
Alexandre e a mulher, Ana [sic] Carolina Peixoto, passaram todo o domingo na delegacia. "Eles estão sendo averiguados porque estavam próximos da vítima”, confirma o delegado Calixto Calil Filho. Alexandre levantou a possibilidade de algum desafeto ter entrado no apartamento e jogado Isabela [sic]. "Está um pouquinho difícil de acreditar nisso, mas não descarto a hipótese", contesta o delegado.

A versão de Alexandre é, assim, desde o início, posta em xeque pela polícia. A reportagem termina da seguinte maneira:

Um operário que trabalhou no prédio se apresentou à polícia. Disse que discutiu com Alexandre por causa de uma antena de TV, mas negou envolvimento com o crime. $\mathrm{O}$ prédio é novo e tem poucos moradores. No sexto andar, só o apartamento de onde a menina caiu está ocupado. Mesmo assim, um vizinho disse à polícia que ouviu gritos logo depois que a família chegou. O depoimento de uma testemunha que pode esclarecer o crime está sendo mantido em sigilo pela polícia.

Se a afirmação do delegado questionou a versão de Alexandre Nardoni (crer-não-ser), esse trecho fornece uma série de elementos que corroboram as dúvidas acerca do envolvimento do pai (crer-ser): seu desentendimento com um operário por causa de uma antena de TV, elemento que indicaria um possível temperamento agressivo de Alexandre; o fato de o andar em que ocorreu o crime não estar sendo ocupado naquela época por outros moradores além dos Nardoni, o que facilitaria uma possível ocultação dos culpados; e, ainda, o fato de uma testemunha ter ouvido gritos após a chegada da família, o que sugere que familiares, talvez, pai e madrasta de Isabella, pudessem estar envolvidos no crime. 
A primeira reportagem sobre o caso indica (crer-ser) como criminosa a causa da morte de Isabella. Pai e madrasta apresentam-se como possíveis culpados, tanto por terem sido ouvidos pela polícia quanto pelos elementos apresentados no parágrafo anterior temperamento do pai, ausência de outros moradores no andar, etc.). Desse modo, o enunciador "Jornal Nacional" crê-ser fortemente, embora não saiba-ser.

Ao sujeito semiótico "telespectador", por sua vez, cabem as seguintes operações concessivas: (1) crer no inacreditável, isto é, crer que uma criança fora morta brutalmente, e (2) crer no (ainda mais) inacreditável: as evidências indicam, ainda que de maneira tênue, que o próprio pai da vítima pode ter sido o culpado. Assim, pela sintaxe intensiva, é por meio de aumentos que o eixo da intensidade opera. $\mathrm{O}$ discurso aqui visa à ascendência. Retomando a tabela da direção ascendente, observamos que a categoria regente é o recrudescimento (cada vez mais mais) e a unidade posta em jogo é a ampliação (acréscimo de pelo menos um mais).

\begin{tabular}{|c|c|c|c|c|}
\hline DIREÇÃ̃O & \multicolumn{4}{|c|}{ CATEGORIAS } \\
\hline \multirow{3}{*}{ Ascendência } & \multicolumn{2}{|c|}{$\begin{array}{c}\text { Restabelecimento } \\
{[\text { cada vez menos menos }]}\end{array}$} & \multicolumn{2}{|c|}{$\begin{array}{c}\text { RECRUDESCIMENTO } \\
\text { [cada vez mais mais }]\end{array}$} \\
\hline & \multicolumn{4}{|c|}{ UNIDADES } \\
\hline & $\begin{array}{l}\text { Retomada } \\
\approx \text { retirada de } \\
\text { pelo menos } \\
\text { um menos }\end{array}$ & $\begin{array}{l}\text { Progressão } \\
\approx \text { retirada de } \\
\text { mais de um } \\
\quad \text { menos }\end{array}$ & $\begin{array}{l}\text { AMPLIAÇÃO } \\
\text { z acréscimo de } \\
\text { pelo menos um } \\
\text { mais }\end{array}$ & $\begin{array}{l}\text { Saturação } \\
\approx \text { acréscimo de } \\
\text { mais de um mais }\end{array}$ \\
\hline
\end{tabular}

Ainda em relação à sintaxe intensiva, o fato semiótico "Caso Isabella Nardoni" adentra com forte impacto o campo de presença do sujeito 
semiótico "telespectador", elevando a intensidade do começo para o fim da reportagem. Por isso, tem-se a direção ascendente. (Da mesma maneira, como poderá ser verificado ao longo desta análise, é uma curva ascendente que caracteriza o corpus até determinado momento.) A sintaxe extensiva, por seu turno, opera somente por triagem: configura-se o sujeito do estupor, momentaneamente, sem temporalidade ou espacialidade. A sintaxe juntiva, por sua vez, aciona o modo concessivo: embora não fosse possível, aconteceu... Com efeito, a primeira reportagem sobre o caso é portadora de uma carga de intensidade elevada e uma baixa carga de extensidade, configurando uma estrutura próxima à do acontecimento, com a diferença de que este, segundo Zilberberg (2011a), desde o início, já possui uma intensidade paroxística.

A segunda reportagem sobre o caso, televisionada em 01/04/2008, traz a seguinte cabeça: "A polícia de São Paulo ouviu nesta terça mais seis pessoas para tentar esclarecer a morte da menina Isabela [sic], que caiu do sexto andar do prédio onde mora o pai dela. Delegado e advogados do pai divergem". Segue um trecho da fala do repórter:

A polícia ouviu nesta terça seis pessoas: três moradores do condomínio, dois ex-vizinhos do casal e o primeiro policial a chegar ao prédio. Uma mesma declaração, feita por duas testemunhas que disseram terem ouvido gritos, provocou divergência entre os advogados do pai de Isabela [sic] e a polícia. "Para, pai. Para pai' é porque o pai tava [sic] fazendo alguma coisa de errado. Não se sabe se a voz era da criança que morreu" [afirmou o delegado]. "Veja bem, uma pessoa que está numa situação de risco fala: 'Para, para' e chama quem? Chama o pai: 'Pai, para. Pai, pai'" [disse o advogado de defesa de Alexandre Nardoni].

As diferentes versões - a do delegado e a do advogado de defesa interpretam distintamente o pedido de Isabella. Para o delegado, teria sido 
uma súplica de clemência para que o pai parasse de agredi-la; para o advogado deste, por sua vez, tratar-se-ia de um pedido da criança para que o pai a socorresse de uma terceira pessoa que lhe estivesse oferecendo perigo. O querer-saber e, ao mesmo tempo, o possível crer no (ainda mais) inacreditável (a partir da interpretação do delegado) modalizam o enunciatário que, no nível tensivo, mantém alta a intensidade do fato semiótico imerso no campo de presença do sujeito.

A reportagem do dia seguinte, 02/04/2008, narra o seguinte:

A polícia de São Paulo pediu a prisão temporária do pai e da madrasta da menina Isabella. [...] $\mathrm{O}$ pedido de prisão temporária foi encaminhado ao Tribunal de Justiça por dois delegados. Um juiz vai decidir se Alexandre Nardoni e Ana Carolina Peixoto serão detidos.

Noticia-se ainda naquela mesma edição:

O juiz Maurício Fossen, do $2^{\circ}$ Tribunal do Júri de São Paulo, decretou a prisão temporária do casal Alexandre Nardoni e Ana Carolina Peixoto por 30 dias, segundo a assessoria do Tribunal de Justiça. Essa prisão pode ser prorrogada por outros 30 dias. Os motivos do pedido de prisão ainda não foram divulgados, mas a expectativa da Justiça é que o casal se apresente o mais rapidamente possível. $[\ldots]$ Os peritos do Instituto de Criminalística permanecem no prédio onde Isabella morreu. Nesta perícia mais minuciosa, eles usam aparelhos sofisticados, que podem detectar vestígios de sangue ou de cabelo, por exemplo, que não são visíveis a olho nu.

O decreto de prisão temporária de Alexandre Nardoni e Anna Carolina Jatobá atenua a modalização do enunciatário pelo querer-saber e tonifica a modalização do “crer no inacreditável”, ou seja, o enunciatário 
"telespectador" estaria, atônito, questionando fortemente se pai e madrasta teriam sido os responsáveis pela morte de Isabella Nardoni, possibilidade corroborada pelo pedido de prisão do casal. A investigação que passara a fazer o Instituto de Criminalística, que, com "aparelhos sofisticados", remontaria a cena do crime, acenava para uma possível solução do mistério em torno da morte de da criança. Cabe aqui enfatizar que a operação "crer no inacreditável” tem caráter intenso, que atordoa o sujeito semiótico (enunciatário) pela possibilidade que se prenuncia.

A reportagem de 03/04/2008 narra:

A entrega do casal começou a ser negociada às $15 \mathrm{~h}$. Os policiais chamaram os advogados e apresentaram novas provas periciais. Segundo a polícia, provas reforçam a investigação sobre o crime. Diante do resultado da perícia, os advogados concordaram em apresentar o pai e a madrasta, que eram procurados desde quarta, quando tiveram a prisão temporária decretada. [...] "São algumas contradições, são vários pontos que precisam ser esclarecidos. A prisão temporária é justamente para isso. A polícia fez a sua parte, colheu os pontos contraditórios, representou ao juiz, o casal está sob custódia, se apresentou e eu acho que a cautela é o melhor caminho", declarou o delegado Aldo Galeano.

Na mesma edição do Jornal Nacional daquela noite, outras duas reportagens sobre o caso foram levadas ao ar. Em uma delas observa-se o trecho:

Alexandre Nardoni e Anna Carolina Jatobá chegaram na noite desta quinta ao Instituto Médico Legal de São Paulo, onde passaram por exames de corpo de delito. Depois, os dois foram levados para carceragens diferentes, onde vão ficar presos por 30 dias. [...] Embora não tenha dado detalhes do porquê da prisão temporária do casal, a polícia ressalta que os 
dois estão sob a custódia do estado e que está tomando todas as medidas de precaução para encontrar provas que esclareçam a morte de Isabella.

Assim, cabe dizer que tanto o trecho da primeira reportagem de 03/04/2008 quanto o da segunda passam a sinalizar ainda mais a possibilidade de Alexandre Nardoni e Anna Carolina Jatobá terem sido os autores do crime. Embora ainda sem provas apresentadas, o Jornal Nacional modalizado por um crer-ser, já parecia creditar ao casal a autoria do crime. Noutros termos, configura-se uma situação em que crer é tônico e o saber, átono. No dia seguinte, 04/04/2008, a reportagem do Jornal Nacional anuncia:

O promotor que acompanha as investigações da morte da menina Isabella afirmou nesta sexta, em São Paulo, que há muitas contradições a serem esclarecidas no caso. Para Francisco Cembranelli, várias versões dadas à polícia pelo pai e pela madrasta da criança são fantasiosas.

Pela sucessão de reportagens sobre o Caso Isabella Nardoni, o enunciatário vai construindo uma espécie de esquema narrativo cujo único programa que não se encontra na dêixis do segredo é a performance: houve um crime. Entretanto, mesmo em relação a esta pairavam dúvidas. Segundo o promotor:

Existem muitos trechos bastante fantasiosos, difíceis de se concretizar. Num primeiro momento, quando eles desceram e havia toda aquela movimentação pra tentar tirar a menina dali, pessoas ouviram ele dizer que havia um ladrão na casa e provavelmente a porta havia sido arrombada por um ladrão. Depois, no depoimento, isso não é mencionado em nenhum momento e a perícia, claro, vai apresentar a conclusão de que não havia sinal de arrombamento. 
Para Francisco Cembranelli, as versões pouco verossímeis de Alexandre Nardoni e Anna Carolina Jatobá reforçam a possibilidade de o casal ser responsável pelo crime: tonificam, pois, um crer-ser. Um argumento de autoridade, de um promotor de justiça, reforça essa probabilidade.

Na mesma reportagem, o magistrado

disse que a investigação deve levar em conta dois outros boletins de ocorrência que envolvem Alexandre Nardoni e Anna Carolina Jatobá. Um deles foi registrado pela mãe de Isabella em 2003. Segundo o documento, Alexandre não aceitava que a filha freqüentasse [sic] uma escolinha e chegou a fazer ameaças de morte à ex-companheira. O outro boletim sobre um acidente de trânsito envolve o casal que hoje está preso. "Alguns boletins de ocorrência que foram anexados e mostram alguns aspectos da personalidade dos envolvidos", finaliza o promotor.

Assim, as reportagens do Jornal Nacional sobre o Caso Isabella Nardoni vão construindo um ethos de um Alexandre Nardoni violento e com antecedentes que corroboram seu potencial de assassino.

Outra reportagem exibida na mesma edição do noticiário afirma: "Um laudo preliminar não indicou presença de drogas ou álcool no sangue do pai e da madrasta de Isabella no dia do crime, mas outros exames e perícias ainda estão sendo realizados". Assim, ao enunciatário cabe deduzir que, se foram Alexandre e Anna Carolina Jatobá os culpados, fizeram-no em amplo gozo de suas faculdades mentais, fato que contribui para a construção de um horror crescente em relação ao caso em pauta. Sendo o próprio pai e/ou a madrasta o(s) culpado(s), rompe-se com o dever segundo a qual os progenitores são responsáveis pela criação e bem estar dos próprios fillhos. 
Matá-los é agir contra essa norma cristalizada constituinte da axiologia vigente $^{50}$.

No espaço tensivo, o sujeito semiótico (enunciatário), ao longo dessas reportagens, percebe uma intensidade inicialmente já elevada, mas que tende a subir com o passar do tempo. Noutros termos, a presença desse fait divers, diariamente na pauta do noticiário, em que cada reportagem apresenta um novo elemento ou retoma um elemento já sabido, intensifica o fato semiótico em questão.

No diagrama a seguir, mostra-se representada a relação entre tonicidade, isto é, o impacto dos novos desdobramentos do caso, e a temporalidade na qual se desenrola caso ${ }^{51}$. Nele, vemos que, desde o início, a tonicidade é elevada, mas que, via recrudescimento, eleva-a ao paroxismo:

\footnotetext{
${ }^{50}$ Com efeito, afirma Freud (2010, p. 101, 125): “A sublimação dos impulsos [pulsões] é um traço especialmente destacado no desenvolvimento cultural $[. .$.$] a cultura precisa fazer de$ tudo para impor limites aos impulsos agressivos do homem". Na mesma obra o pai da psicanálise ainda assevera: "A cultura domina a perigosa agressividade do indivíduo na medida em que o enfraquece, desarma e vigia através de uma instância em seu interior (p. 144).

${ }^{51}$ Embora na obra de Zilberberg a relação conversa comece sempre com intensidade mínima visando ao paroxismo nesse eixo, baseamo-nos na curva de $\mathrm{n}^{\circ} .8$ proposta por Hebert (2006, p. 44 ), que propõe uma série de possibilidades entre intensidade e tempo [time]. [Disponível em: http://www.revue-texto.net/Parutions/Livres-E/Hebert_AS/4.TensiveModel.pdf.] A que mostramos acima se mostrou mais adequada para a representação das oscilações tensivas no que se refere à tonicidade e a temporalidade no Caso Isabella Nardoni.
} 


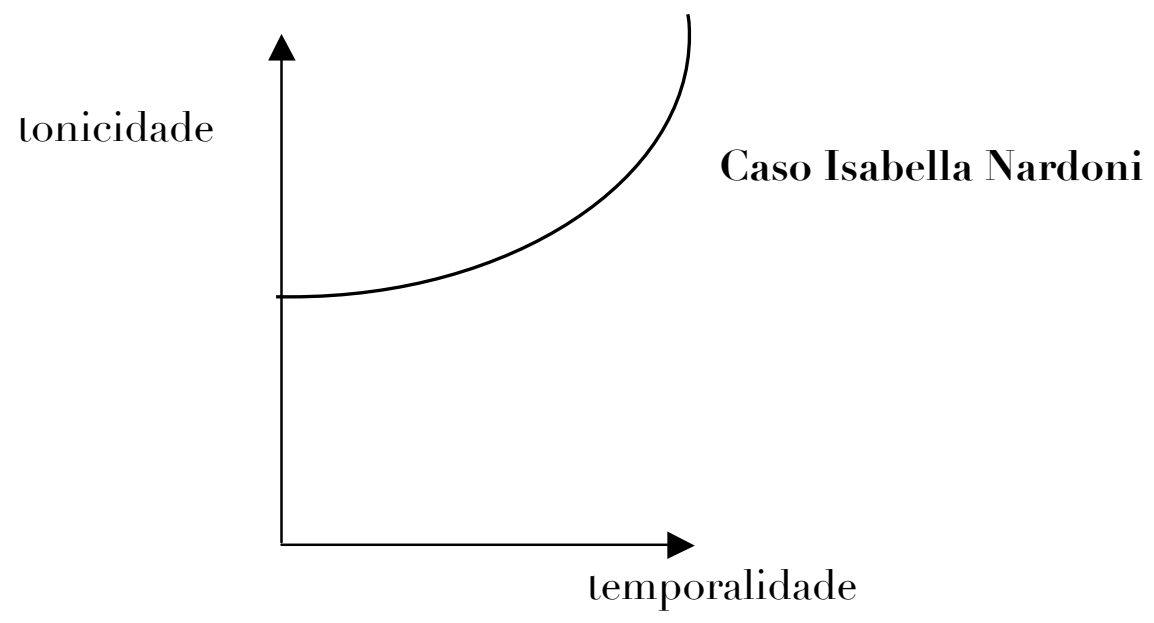

Vê-se, pelo diagrama, uma intensidade já alta que tende a crescer. Se retomarmos parte da tabela na qual Zilberberg (2011a) relaciona a recção de uma dimensão da intensidade, a tonicidade, sobre outra da extensidade, a temporalidade, temos o efeito de persistência:

\begin{tabular}{|c|c|c|}
\hline RECÇÃO DE UMA & TIPO DE & EFEITO \\
SUBDIMENSÃO POR OUTRA & CORRELAÇÃOO & \\
\hline Tonicidade $\rightarrow$ Temporalidade & Conversa & PERSISTÊNCIA \\
(pertencentes à mesma dimensão) & & \\
\hline
\end{tabular}

Assim, esse fato semiótico persiste no tempo, tornando mais intensa sua carga tímica. Essa é uma das explicações, via tensividade, por que o caso durou. Segundo Zilberberg (2011a, p. 70), também a projeção da tonicidade sobre a temporalidade "alonga a duração e produz o memorável, esse futuro do passado"”. Assim, a persistência dá-se não somente no tempo cronológico, como também no "tempo da memória". 
Ainda que a próxima subdivisão se dedique mais detidamente à relação entre duração e intensidade, essa questão, por perpassar nosso problema de pesquisa, é interessante ser trazida à discussão também neste momento. Ora, se estamos lidando com os conceitos de concessão e de fidúcia, sendo que o primeiro intensifica o segundo, de modo a deixar o sujeito semiótico "sem voz", esse efeito de persistência ocasionado pela projeção da tonicidade na temporalidade deve ser levado em conta. Assim, a sensação de "crer no inacreditável” no caso aqui enfocado tem, ademais, aspecto durativo.

Naquela mesma edição do noticiário, afirma-se: "O caso Isabella abre a discussão e criminalistas ouvidos pelo Jornal Nacional dizem que a prisão temporária não deve ser interpretada como uma sentença de culpa”. Segue outro trecho:

A prisão temporária é pedida para que um suspeito seja investigado. Criminalistas ouvidos pelo Jornal Nacional dizem que ela não deve ser interpretada como uma sentença de culpa. Uma criança morta, nenhuma testemunha ocular e duas pessoas presas. Esses são os elementos de uma investigação que ainda está longe de ser concluída. Logo apos [sic] a prisão, a polícia pediu cautela. "Nós não podemos entrar em polêmica e cometer qualquer erro, qualquer injustiça. Nós precisamos ter prudência, cautela", disse o delegado Aldo Galeano Júnior. Então por que Alexandre e Ana Carolina foram presos? Está na lei: a prisão temporária pode ser decretada quando há homicídio e quando a detenção de um suspeito é considerada imprescindível para a investigação.

Pelo que se observa nos trechos acima, ao menos no âmbito do parecer, o Jornal Nacional não emite uma sentença de culpa: ele não sabe-ser, embora creia-ser. Com efeito, um dos princípios do discurso jornalístico é 
dar voz a todos os lados da questão. No que respeita especificamente a esse noticiário, Chrystus (2007, p. 182) afirma:

Fiel ao seu estilo "imparcial", a notícia se constrói mostrando os chamados "dois lados" da situação. Qualquer que seja o tema ou a reportagem, sempre haverá dois lados, num evidente dualismo: nem um, nem três, nem cinco sempre dois lados da questão.

O "estilo imparcial" a que se refere a autora encontra ainda ressonância na fala do próprio apresentador e editor-chefe William Bonner (2009, p. 25), segundo o qual, o objetivo do Jornal Nacional é: "mostrar o que mais importante aconteceu no Brasil e no mundo, com isenção, pluralidade, clareza e correção" (itálicos nossos). Um dos efeitos dessa isenção ou imparcialidade é justamente conceder a fala aos dois lados implicados no caso. Entretanto, seria ingênuo crer que isso garantisse neutralidade a qualquer discurso.

Em 11/04/2008, o noticiário afirma:

O promotor que acompanha o caso voltou a falar nesta sexta num suposto envolvimento do casal Alexandre Nardoni e Ana [sic] Jatobá na morte de Isabella. Para a polícia, só falta a liberação dos laudos para encerrar as investigações. [...] Segundo a promotoria, já existem provas periciais importantes. "Há informações preliminares do Instituto de Criminalística que nos permitem concluir, são informações categóricas, que permitem vincular o casal aos ferimentos sofridos por Isabella e ao que ocorreu propriamente dito na cena do crime", afirmou o promotor Francisco Cembranelli. Segundo o promotor, depoimentos apontariam inclusive a motivação do assassinato. "Essas testemunhas confirmaram, não é uma ou duas, que 10 minutos antes de tudo ocorrer deu-se uma ferrenha discussão entre o casal no interior do apartamento. Sendo reconhecida a voz da pessoa que 
discutia comparada posteriormente com a voz de Ana [sic] Jatobá”.

Pelo trecho transcrito e pelo percurso de análise que se vem traçando até agora, cada vez mais se configura um sujeito "telespectador" crédulo no inacreditável, no surpreendente. Aqui, retomamos a relação do "já/ainda não”, de Paul Valéry, que, em obras de alguns semioticistas, vem ganhando operacionalidade (Cf. ZILBERBERG 2011a; TATIT, 2010).

Segundo Valéry (1973, p. 1290), “o que (já) é não é (ainda) - eis a Surpresa. O que (ainda) não é, (já) é - eis a espera”. Assim, pelo esquema do autor, aos olhos da semiótica, a surpresa configura uma situação em que o objeto adentra bruscamente o campo de presença do sujeito, para quem aquele ainda não "era”, ou seja, o sujeito não estava preparado para recebêlo. Com efeito, para Valéry (1973, p. 1288), "todo acontecimento brusco atinge o todo", o sujeito em sua integralidade. Opostamente, a espera configura uma situação em que o objeto já existe de forma atualizada para o sujeito, mas não de forma realizada. Podemos aqui relacionar a noção de surpresa com a de acontecimento, que "já [está] presente na ordem do sensível, mas ainda não compreendida na ordem do inteligível" (ZILBERBERG, 2011a, p. 193).

Assim, no que respeita à surpresa/acontecimento, tem-se um campo de presença cujo eixo da intensidade visa à saturação. Devido à persistência já aludida, esse estado de cada vez mais mais vai paulatinamente afetivando, intensificando, o campo de presença do sujeito semiótico (enunciatário).

Aqui, caberia um acréscimo ao esquema de Valéry a respeito da surpresa. Pelo que se depreende do texto em análise, poder-se-ia dizer que 
se o que sobreveio é inacreditável, o que está por vir prenuncia-se como algo ainda pior. Desse modo, a partir de uma surpresa inicial, o sujeito semiótico prepara seu espírito - agora, a espera - para, por assim dizer, a má-notíciasuperlativa: o fato de pai e madrasta serem, de fato, os assassinos de Isabella. Vejamos, pois, como isso pode ser observado no corpus.

Em 15/04/2008, uma reportagem no Jornal Nacional narra: “Os exames feitos depois de Isabella ter sido jogada pela janela mostraram que ela tinha marcas no pescoço, manchas no pulmão e no coração. As pontas dos dedos também estavam avermelhadas, sinais de asfixia”. Naquela mesma edição do noticiário, outra reportagem afirma:

Na noite do assassinato de Isabella, um casal ouviu uma violenta discussão que vinha de outra janela, quase em frente. O quarto de Alexandre Nardoni e Anna Carolina Jatobá. "Em discussões, apareciam uma pessoa da voz feminina principalmente e a voz masculina pouco se ouvia. Praticamente nada. Mas a voz feminina ficou muito marcada devido às palavras de baixo calão que se pronunciavam. Eram muitos palavrões. Não era uma briga típica de casal. Era uma briga de desespero", conta a vizinha.

Pelos excertos apresentados, vai se configurando, após a surpresa inicial - o assassinato -, uma espera tensa, temerosa pelo pior. Em 18/04/2008, esse temor ganha ainda mais em intensidade:

Esta sexta-feira foi decisiva para a conclusão do inquérito que investiga a morte de Isabella Nardoni. A polícia decidiu indiciar o pai e a madrasta pelo assassinato. $\mathrm{O}$ casal prestou novos depoimentos numa delegacia de São Paulo. O interrogatório de Alexandre Nardoni durou oito horas. Ele foi indiciado por homicídio doloso, com intenção de matar. A expectativa sobre o interrogatório de Anna Carolina Jatobá é que entre pela madrugada. A polícia já adiantou que ela 
também será indiciada pela morte da Isabella (itálicos nossos).

O indiciamento de Alexandre Nardoni por homicídio doloso é o prenúncio de uma série de fatos que passam a vincular o casal de forma cada vez mais inequívoca à morte de Isabella. Assim, em 19/04/2008, o Jornal Nacional revela que:

Segundo a perícia, Isabella chegou machucada ao prédio. Ela foi ferida na testa por um objeto pontiagudo e sangrou dentro do carro. [...] Do carro até o apartamento, não havia rastro de sangue. Para os peritos, isso significa que o sangue da menina foi estancado e, para isso, foi usada a fralda mais tarde encontrada no apartamento. A fralda estava mergulhada na água, mas os exames revelaram vestígios de sangue de Isabella. Pela seqüência [sic] estabelecida pela perícia, a fralda foi retirada do rosto de Isabella na entrada do apartamento, onde começa o rastro de sangue. Isabella estava inconsciente ou imobilizada. Havia ferimentos na parte interna dos lábios, provocados pela pressão contra os dentes, o que demonstra que alguém segurou com força a boca da menina. A intenção seria impedir que ela gritasse. $O$ rastro de sangue vai até perto do sofá, onde Isabella foi deixada no chão. Nesse local, havia uma concentração maior de sangue. Os peritos também concluíram que, nesse momento, Isabella estava com as pernas flexionadas, o que explica o formato do pingo de sangue na calça. Enquanto isso, a tela de proteção do quarto era cortada. A mesma pessoa que entrou com Isabella no apartamento pegou a menina de novo no colo e seguiu para o quarto de onde ela seria jogada. Todos os pingos caíram de uma altura de pelo menos um metro e vinte e cinco. Conclusão dos peritos: Isabella estava no colo de uma pessoa com altura compatível com a de Alexandre. Com a menina no colo, o agressor tentou subir na cama, em direção à janela, mas escorregou. $O$ colchão ficou com o que os peritos chamam de esfregaço, a marca de um chinelo compatível ao que Alexandre usava no dia do crime. [...] O agressor, então, ajoelhou-se na cama e passou o corpo de Isabella pelo buraco da rede. Segundo a perícia, o assassino segurou a criança de frente para ele, 
passou primeiro os pés dela pelo buraco, agarrou a menina pelos pulsos e soltou primeiro a mão esquerda. As marcas das pontas dos dedos e dos joelhos da menina ficaram na fachada do prédio. Na camiseta que Alexandre Nardoni usava no dia do crime, os peritos encontraram o desenho da trama da rede. Segundo eles, a sujeira e a pressão exercida sobre a tela deixaram marcas inconfundíveis, marcas que só seriam possíveis se ele tivesse pressionado firmemente o corpo contra a rede, com os braços esticados. Era a posição de quem jogou Isabella. [...] Os peritos também concluíram que os sinais no pescoço de Isabella são compatíveis com as mãos da madrasta e que não havia mais ninguém na cena do crime além do casal.

Pela descrição minuciosa, de caráter eminentemente figurativo, o enunciador (re)constrói discursivamente a circunstância da morte de Isabella. O sujeito semiótico (enunciatário), a quem só resta um sofrer, vê seu campo de presença em contínuo estado de recrudescimento.

Na mesma edição daquela noite, o noticiário conta que, após longo interrogatório, Alexandre Nardoni e Anna Carolina Jatobá

foram formalmente acusados de homicídio doloso e triplamente qualificado, ou seja, segundo a polícia paulista, o casal matou a garota com intenção, por motivo infame e brutal, usando crueldade e sem dar chance de defesa à vítima.

Em 28/04/2008, o Jornal Nacional afirma: "Eles [Alexandre Nardoni e Anna Carolina Jatobá] devem ser denunciados à Justiça por homicídio qualificado. Isso deve acontecer até a terça-feira que vem”. Em 05/05/2008, o Jornal Nacional traz a seguinte notícia: "O Ministério Público de São Paulo vai denunciar nesta terça Alexandre Nardoni e Anna Carolina Jatobá pela 
morte da menina Isabella". Na edição do dia seguinte, a confirmação da denúncia:

O promotor Francisco Cembranelli ofereceu hoje denúncia à justiça - e pediu a prisão preventiva de Alexandre Nardoni e Anna Carolina Jatobá. Ele afirma que há evidências suficientes para levar o casal a júri popular, pela morte da menina Isabella. O promotor Francisco Cembranelli foi categórico: Alexandre Nardoni e Anna Carolina Jatobá mataram Isabella. Eles foram denunciados por homicídio doloso, em que há a intenção de matar, triplamente qualificado, ou seja, por meio cruel, sem chance de defesa para a vítima e por ter sido cometido para ocultar outro crime.

No dia 07/05/2008, corrobora-se o "ainda pior" da espera do sujeito semiótico:

O juiz Maurício Fossen aceitou a denúncia do promotor Francisco Cembranelli e decretou a prisão preventiva de Alexandre Nardoni e Anna Carolina Jatobá. Os dois são acusados da morte da menina Isabella, no dia 29 de março.

Outra reportagem naquela mesma edição diz que: "Maurício Fossen considerou que o inquérito deixou claro o que Anna Carolina Jatobá e Alexandre Nardoni fizeram para matar Isabella. O processo já foi aberto e os dois passaram a ser réus" (itálicos nossos).

Em 08/05/2008, afirma-se que:

Alexandre Nardoni está numa delegacia na Zona Norte da cidade. Anna Jatobá, por medida de segurança, foi isolada numa cela da penitenciária feminina, também na Zona Norte. [...] Anna Carolina Jatobá e Alexandre Nardoni, indiciados em 18 de abril pela morte de Isabella, agora são réus 
no processo em que aparecem como autores do crime que chocou o país (itálicos nossos).

O “ainda pior" é, assim, formalmente instaurado. A relação entre a surpresa inicial - a morte de Isabella - e o desenrolar dos fatos relativos a seu assassinato configuram um estado de espera cada vez mais tônico, pois todas as evidências apontam a autoria do crime para o pai e para a madrasta da criança. Figuralmente, podemos retomar o diagrama já apresentado que relaciona tonicidade e temporalidade:

\section{Caso Isabella Nardoni}

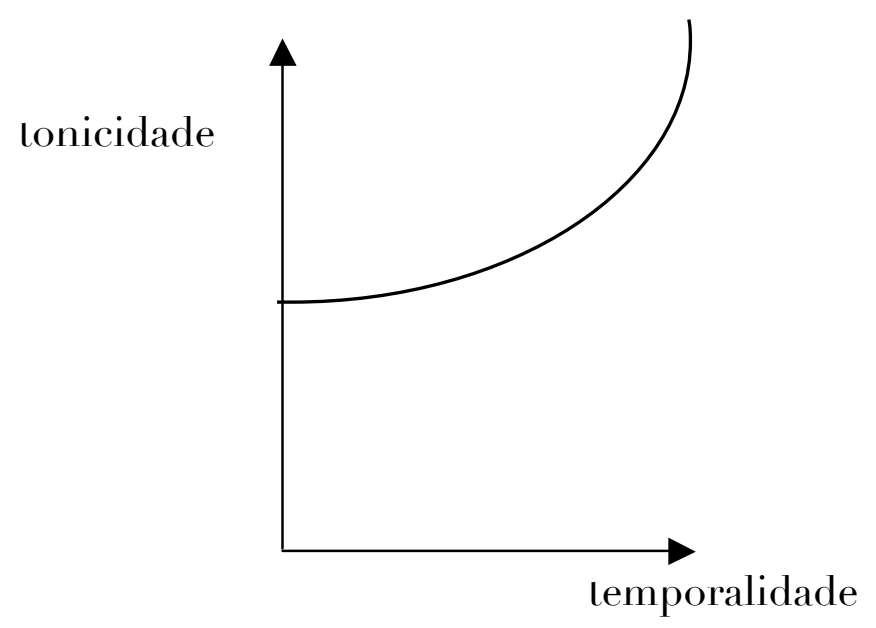

O ponto mais alto da curva, isto é, o mais intenso e também o mais extenso, representa, assim, o ápice do horror, sentido pelo sujeito semiótico: tudo indica que são mesmo eles os assassinos da própria filha/enteada. Esse pico configura uma espécie de acontecimento, cuja intensidade paroxística só agora se instaura. Se o choque causado pela morte de Isabella fora 
intenso desde a primeira reportagem aqui analisada, a intensidade máxima é obtida neste momento: pela confirmação do "ainda pior". É essa sensação de “não pode ser! não pode ser! - mas é!", ou seja, a relação entre concessão e fidúcia encontra aqui a saturação. O diagrama a seguir representa essa relação graficamente:

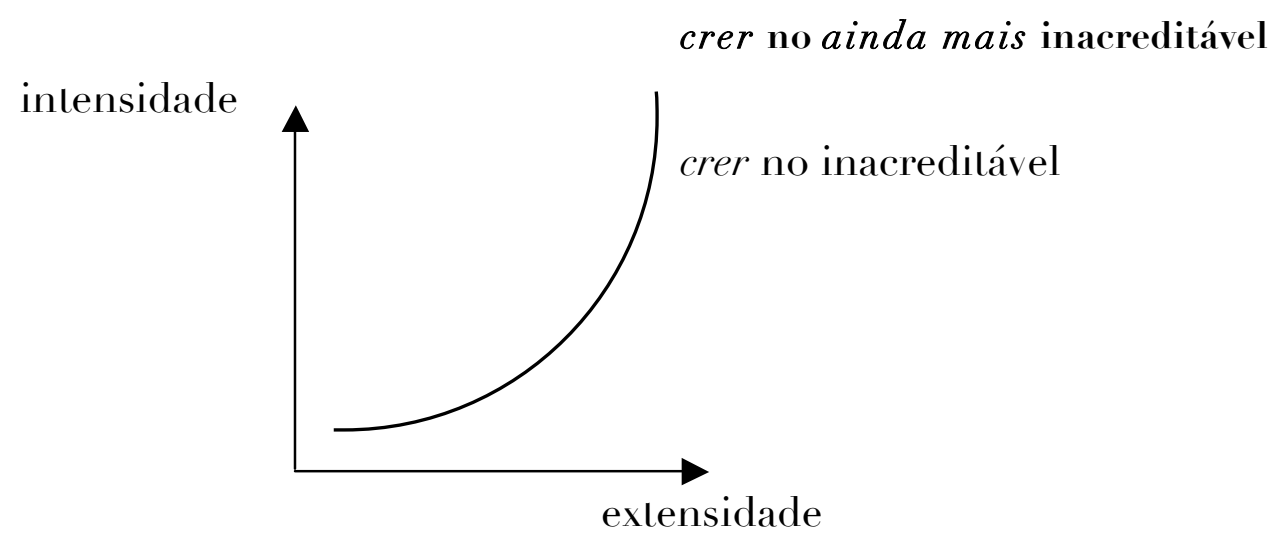

Assim, pela ótica da tensividade, observamos que "crer no inacreditável", hipoteticamente o clímax da intensidade, ou seja, a unidade "saturada" (acréscimo de apenas mais) não o é, mas, trata-se, por sua vez, ainda de uma unidade "ampliada" (acréscimo de pelo menos um mais). O "cúmice do ápice" - expressão de belo neologismo que emprestamos de um poema de Adélia Prado (2001, p. 478) - é percebido somente no "crer no ainda mais inacreditável", este, sim, configura-se como unidade "saturada". Portanto, o corpus nos permite inferir que o modo concessivo também admite graus: "crer no ainda mais inacreditável" é mais concessivo que "crer no inacreditável”. 
A relação entre fidúcia e concessão à luz da qual direcionamos a análise do corpus, nesta subseção, demonstrou uma relação inicialmente conversa entre intensidade, especificamente a tonicidade, extensidade, em particular a temporalidade. O discurso, com direção ascendente, ampliou-se, em termos de intensidade, saturando-se, por fim. A saturação é, pois, o ápice da curva.

$\mathrm{O}$ discurso funcionando à maneira dos prosodemas, a direção ascendente que recrudesceu até saturar, inevitavelmente, será sucedida por uma direção descendente, a qual se rege pela categoria da atenuação (cada vez menos mais). Desta categoria, opera inicialmente a unidade moderação (retirada de pelo menos um mais) e, em seguida, a unidade diminuição (retirada de mais de um mais). Noutros termos, a curva ascendente passa a ser descendente, conforme pode ser visto no seguinte diagrama:

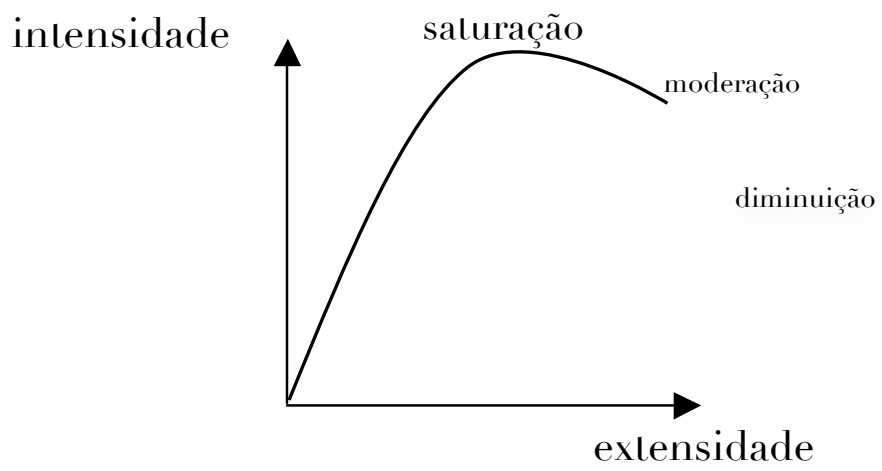


Assim, se unirmos uma curva ascendente a uma curva descendente, tal como sugere o diagrama acima, teríamos uma parábola, a qual funde uma relação inicialmente conversa e posteriormente inversa ${ }^{52}$ :

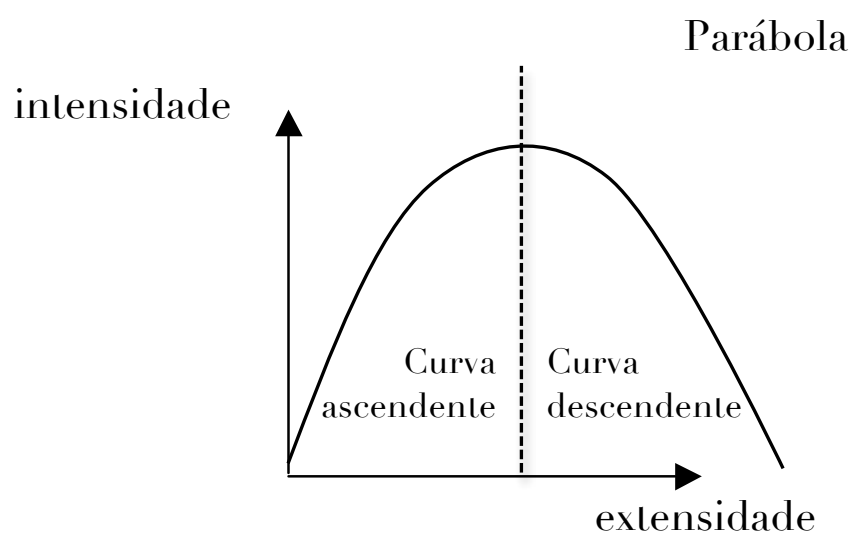

Pensamos, assim, que a relação entre fidúcia e concessão pode ser um dos caminhos pelos quais se pode explicar discursivamente o interesse do enunciatário e também o fato de o Caso Isabella Nardoni fazer-se presente no campo de presença, cada vez mais afetivado, do sujeito semiótico. Dessa forma, pelos pares mais e menos - "o dinheirinho trocado" do discurso, nas palavras de Zilberberg (2011a, p. 49) - explica-se, via fidúcia e concessão, a duração desse fait divers que, por princípio, deveria ter uma estrutura acontecimental: pouco extensa e muito intensa.

\footnotetext{
${ }^{52}$ Lopes (2004) apresenta os modelos da "paisagem sinusoidal", baseada na obra de B. Pottier, e da "cúspide", segundo R. Thom. Embora utilizados para outros fins e em outros contextos de uso, tais modelos inspiraram-nos a formular essa parábola, que reúne uma correlação ascendente sucedida de uma correlação descendente, a qual, por sua vez, traduz graficamente as oscilações tensivas do caso em análise.
} 
Assim, como se viu, ao lado de um fazer-saber e/ou fazer-crer, o enunciador busca, no caso em foco, sobretudo, um fazer-sentir que garante a fidelização de seu enunciatário, por meio da estesia, do afeto. E se a intensidade é regente da extensidade, esse fazer-persuasivo "estésico", pelo menos a priori, leva grande vantagem no que se refere à adesão do enunciatário se comparado a um fazer-persuasivo puramente cognitivo. Nesses termos, o objetivo da enunciação, para além da adesão em sentido estrito, é a manutenção da fidelidade do enunciatário, o gerenciamento de sua atenção e de sua curiosidade. Isso, afinal, cumpre a função de manter telespectadores fiéis ao programa jornalístico em pauta. Assim, tal fazerpersuasivo de natureza estésica visa, em última instância, à permanência da interação, da comunicação.

A esse respeito, resta dizer ainda que qualquer notícia pode ter uma dimensão afetiva. No entanto, pode-se apelar mais ou menos para seu aspecto sensível. A nosso ver, privilegiar o aspecto afetivo do relato jornalístico configura-se como uma estratégia do enunciador que visa a ampliar o número possível de enunciatários “telespectadores”. Desse modo, se o enunciador se ancorasse unicamente no cognitivo, acabaria privilegiando um enunciatário mais escolarizado. Por outro lado, ao centrarse no afetivo, consegue abarcar enunciatários de todos os níveis sociais e de escolaridade. Isso porque todos têm um lado afetivo, humano, que se choca e se põe no lugar do outro, em maior ou menor grau. 


\subsubsection{Duração e intensidade: do acontecimento aos microacontecimentos}

A duração do Caso Isabella Nardoni na mídia, e, nesta análise, especificamente no Jornal Nacional, ou, de forma mais exata, a “extensivização" da intensidade desse fait divers, já dissemos, é nossa questão teórica. Na subseção anterior, procuramos demonstrar por meio da relação dos conceitos de fidúcia e concessão o porquê de esse fato semiótico ter durado significativamente no campo de presença do sujeito. Na presente subseção, retomamos esse problema, não pelo viés dos conceitos já mencionados, mas sobretudo pelos pequenos fatos - ou "microacontecimentos", por assim dizer - que sucederam o assassinato noticiado pela primeira reportagem sobre a morte de Isabella Nardoni.

Cabe, assim, definir o conceito de microacontecimento, tal como o concebemos no âmbito deste trabalho. Microacontecimentos são compreendidos como eventos secundários que se relacionam a um evento principal e motivador. No caso em questão, o acontecimento principal se refere à morte de Isabella Nardoni, noticiada na primeira reportagem de nosso corpus. Microacontecimentos são, por assim dizer, fragmentos, estilhaços do acontecimento principal: notícias veiculadas posteriormente que agregam alguma nova informação ao caso, impedindo que sua intensidade decresça num curto período de tempo. Conforme exposto no Capítulo 2, embora Zilberberg (2007, p. 16) utilize a distinção fato/acontecimento, atribuindo maior intensidade e raridade para o segundo, fazemos uso do conceito de microacontecimento justamente para marcar a contiguidade entre o acontecimento motivador e os pequenos eventos ulteriores ligados a ele. 
A nosso ver, esses elementos novos, a cada edição, contribuíram sobremaneira para que o episódio mantivesse alta sua intensidade malgrado o passar o tempo. Assim, antes de passarmos diretamente à análise do corpus, apresentamos dois conceitos formulados, a partir de aplicações da noção zilberberguiana de acontecimento, por Tatit (2010) e por Gomes (2012). As proposições desses autores são bastante profícuas no sentido de especificar a natureza do corpus desta pesquisa, além de fornecer subsídios para nossa análise.

\subsubsection{Acontecimento extenso}

Comecemos pelo que Tatit (2010, p. 117) chama de "acontecimento extenso". O autor, ao analisar o conto "A terceira margem do rio", de Guimarães Rosa (2005), depreende a seguinte questão: "Como tornar habitual um acontecimento extraordinário?" No conto, o pai “abandona o cotidiano regrado de sua vida familiar para passar o resto de seus dias isolado numa canoa especialmente fabricada para 'durar na água” (TATIT, 2010, p. 107). Para o autor,

não é $[\ldots]$ o fato em si que singulariza o acontecimento, mas seu coeficiente temporal e espacial: o período de permanência sobre as águas estende-se para além de qualquer previsão razoável e o espaço normalmente aberto às duas margens fecha-se num habitat de todo improvável para a vida humana (TATIT, 2010, p. 108).

Na leitura empreendida por Tatit (2010), a grande extensão temporal daquele episódio implica um andamento desacelerado, do mesmo modo que, devido ao fechamento do espaço, tem-se uma forte tonicidade. 
O filho abandonado pelo pai é o que mais sofre devido ao impacto das visões sucessivas "que se acumulam, ampliando a repercussão do fenômeno no espírito do filho" (TATIT, 2010, p. 116). Para o semioticista, "não há com o que se acostumar, pois todas as aparições estão qualificando e construindo - a complexidade do mesmo acontecimento" (itálicos nossos) (TATIT, 2010, p. 116). Assim, para o autor, o filho é afetado por um mesmo evento: o ato de ver o pai sobre a canoa, por inúmeras vezes, durante anos a fio.

O querer-saber por que o pai tomara tal atitude e, ademais, a questão que se impunha para o filho sobre quanto tempo aquilo ainda duraria, mas, sobretudo, o acúmulo daquelas visões configuram o que Tatit (2010, p. 117) chama de práticas impregnantes. Estas relacionam-se com o conceito denominado pelo autor de "acontecimento extenso", isto é, "aquele que só se realiza plenamente ao cabo de numerosas ocorrências do mesmo gesto ou do mesmo fenômeno" (itálicos nossos). O acontecimento, por essa ótica, está prenhe de si mesmo: só se realiza, só eclode, após uma "gestação", um período de tempo no qual vai se gerando. Com efeito, o termo pregnância, indica o Houaiss, vem do inglês pregnance e significa "condição de estar prenhe".

Portanto, pela análise que Tatit $(2010)$ realiza de "A terceira margem do rio", remete-se a um mesmo acontecimento - frise-se - que se repete por uma longa duração e que, ao final, realiza-se por completo. Conforme afirmamos anteriormente, o Caso Isabella Nardoni não se compõe de um mesmo acontecimento, mas de um acontecimento motivador e inicial - o assassinato - que reverbera, mas também por uma irrupção de microacontecimentos responsáveis por mantê-lo em evidência. 


\subsubsection{Acontecimento reverberado}

Gomes (2012), por sua vez, analisa textos jornalísticos à luz da relação entre os conceitos de modalização e aspectualização, "observando como o arranjo desses procedimentos podem explicar as tensões entre o surgimento do inesperado e o conforto do desdobramento de uma expectativa" (p. 12). A abordagem da autora fornece-nos algumas contribuições para pensar nosso caso sob exame.

Ao analisar a notícia "Corveta chega a Recife com mais destroços do Airbus", Gomes (2012, p. 14) mostra que a chegada dos restos da queda do avião “abre uma expectativa da explicação do fato a ser 'desvendado' por especialistas" (p. 14). Para a semioticista,

o narrador introduz no texto um "programa narrativo virtual", ao discursivizar um querer e um dever investigar, que impulsionam a busca de um saber. [A] narrativa [portanto] só chegará a termo em edições posteriores do jornal (GOMES, 2012, p. 14).

Em outra notícia analisada, "Fisioterapeuta salva vizinhos em incêndio", a autora se baseia num mecanismo de persistência "numa amplificação da extensão de fatos, já dados como acabados sob outro ponto de vista, como uma espécie de reverberação dos acontecimentos" (itálicos nossos). No caso em pauta, a notícia tem aspecto acabado - o incêndio já havia ocorrido, as vítimas já haviam sido salvas - entretanto, mostra Gomes (2012, p. 18) que, “dois dias depois, outra notícia é publicada, tratando das impressões da idosa quanto à experiência do salvamento do incêndio. [...] $\mathrm{O}$ inesperado detalhe, então, faz prolongar a matéria, mesmo que a ação principal esteja concluída" (itálicos nossos). O detalhe, aludido pela autora, 
não cumpre uma função informativa, mas, sim, de reverberar o acontecimento a que se refere a notícia.

Gomes (2012) examina ainda outro texto jornalístico, acerca de um deslizamento em um morro em Niterói $(\mathrm{RJ})$, que ocasionou a morte de várias famílias por soterramento. Trata-se, dessa maneira, de um fato fortemente inesperado e traumático. Em casos como esse, cria-se um efeito de duração: “a extensão das notícias por várias edições”. Assim, “o sobrevir, tomado como espanto, persiste e exige uma demora em relação à apreensão, tornando possível a assimilação do caótico $[\ldots]$ transformando o que sobrevém em memória (GOMES, 2012, p. 18). Com efeito, como diz Valéry (1973, p. 1235): “O intenso [...] tem uma qualidade própria - que é de persistir além da duração de sua causa”.

Pelas análises de Gomes (2012), evidenciam-se dois elementos que permitem um diálogo com nosso corpus. Em primeiro lugar, tem-se o que a autora chama de um "programa narrativo virtual" que motiva um querersaber. Esse arranjo modal é responsável pela conservação do interesse do enunciatário, mantendo um fato sob os holofotes da mídia. Em segundo, tanto no caso do incêndio quanto no do deslizamento, cria-se o que a autora chama de "reverberação dos acontecimentos", uma vez que, após a notícia principal, de forte carga tímica, motiva-se uma série de outras, que visam a estabelecer o contraprograma aludido por Zilberberg (2011a), que converte o limiar do discurso em discurso: o sensível em inteligível.

Relacionando as notícias estudadas por Gomes (2012), podemos estabelecer algumas semelhanças com o Caso Isabella Nardoni. Primeiramente, há, de certo modo, um "programa narrativo virtual": não se conheciam as causas da morte da criança, o que motivou um querer-saber: 
uma causa perturbada, segundo Barthes (1964). Ademais, trata-se de um caso traumático, que gera, segundo o termo de Gomes (2012), um “acontecimento reverberado".

\subsubsection{Análise II}

Essa reverberação e a irrupção de microacontecimentos, que conjugam intensidade e extensidade, conduzem nossa análise na presente subseção. Pensamos que o desenrolar do discurso a partir da morte da criança corrobora nossa tese do porquê de o caso ter durado tanto na esfera midiática, com uma carga tímica tão elevada. Nesta subseção, ademais, cabe dizer que também levamos em conta a associação dos aspectos verbais com os visuais que constituem o corpus, porquanto sem o componente visual, perder-se-ia muito do potencial de análise do texto sincrético em questão.

Na primeira reportagem sobre o crime, de 31/03/2008, exibida pelo Jornal Nacional, o repórter afirma: "Investigadores buscam pistas que possam ajudar a esclarecer a morte de Isabela [sic]. Nesta segunda-feira, depois do enterro, o comerciante José Arcanjo de Oliveira, avô da menina, quebrou o silêncio da família”. Na sequência de quadros, veem-se um perito fotografando o local do crime, uma fotografia de Isabella sorrindo, e uma tomada aérea do enterro. 

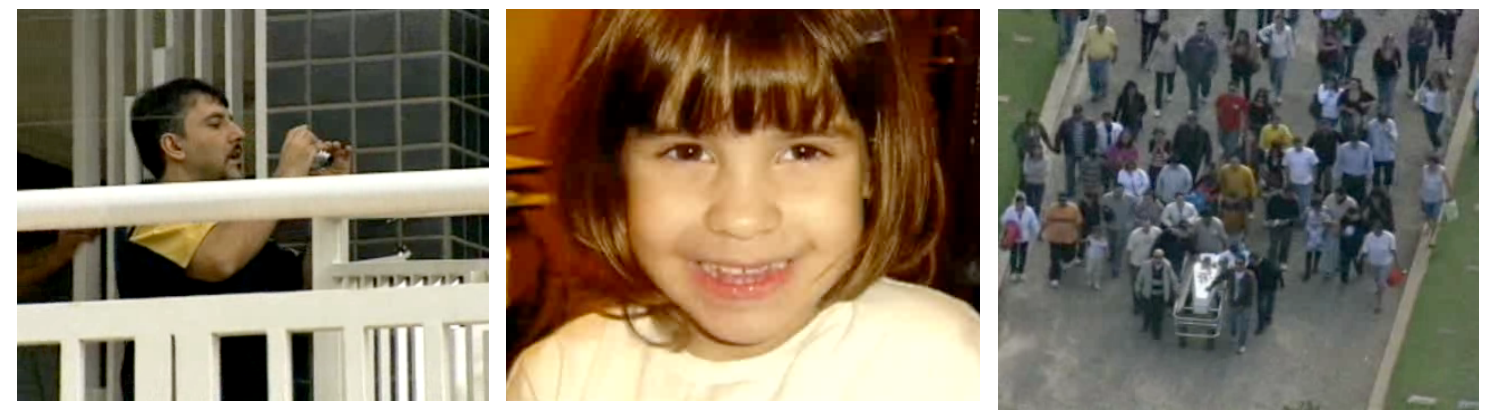

O primeiro quadro tematiza a investigação da morte de Isabella, a qual, no nível narrativo, repercute em um querer-saber a que já nos referimos. O segundo, por sua vez, exibe uma menina sorridente, branca para os padrões brasileiros, de cabelos lisos. Tal descrição se coaduna com o estereótipo de uma menina bonita, numa cultura cujo modelo eufórico de beleza é o europeu, conforme já foi mencionado ${ }^{53}$. O terceiro quadro exibe o corpo de Isabella, num caixão branco, visto de cima. Pelos dois últimos quadros, depreende-se a categoria do nível fundamental vida $s$. morte, que, por sua vez, configura a oposição semântica de base do Caso Isabella Nardoni.

Segue a narração da reportagem:

A polícia não tem dúvidas de que Isabela [sic] foi jogada do sexto andar de um prédio, no sábado à noite. A tela de proteção da janela foi cortada e o retalho ficou no apartamento. A menina passava o fim de semana com o pai, Alexandre Nardoni, com a mulher do segundo casamento e dois filhos do casal. Alexandre contou à polícia que voltou para a casa com a família, depois de visitar a sogra. Disse que, primeiro, subiu com Isabela. Acendeu a luz do abajur do quarto dela e deixou a menina dormindo. Depois, trancou a

\footnotetext{
${ }^{53}$ Corrobora essa asserção o fato de, em 03/04/2008, uma mãe de um colega de sala de Isabella ter textualmente afirmado: "Ela era linda, sorridente".
} 
porta do apartamento e voltou à garagem para ajudar a mulher, que estava no carro com os dois filhos pequenos. Contou que, ao entrar em casa, a luz do quarto estava acesa. Chegou a pensar que a menina tivesse caído da cama. Disse que, em seguida, notou a rede de proteção da janela cortada. Aí, viu o corpo de Isabela [sic] no jardim do prédio. Só quando os peritos entraram no apartamento, perceberam que era a tela do outro quarto que estava cortada. Isabela [sic] caiu do quarto dos irmãos.

Na sequência de quadros, são mostrados: outra foto de Isabella, sorridente, ao lado de alguém cuja imagem fora desfocada propositalmente; o edifício, numa imagem noturna, onde morava a família de Alexandre Nardoni; e a tela de proteção rasgada da janela de onde a menina fora defenestrada.
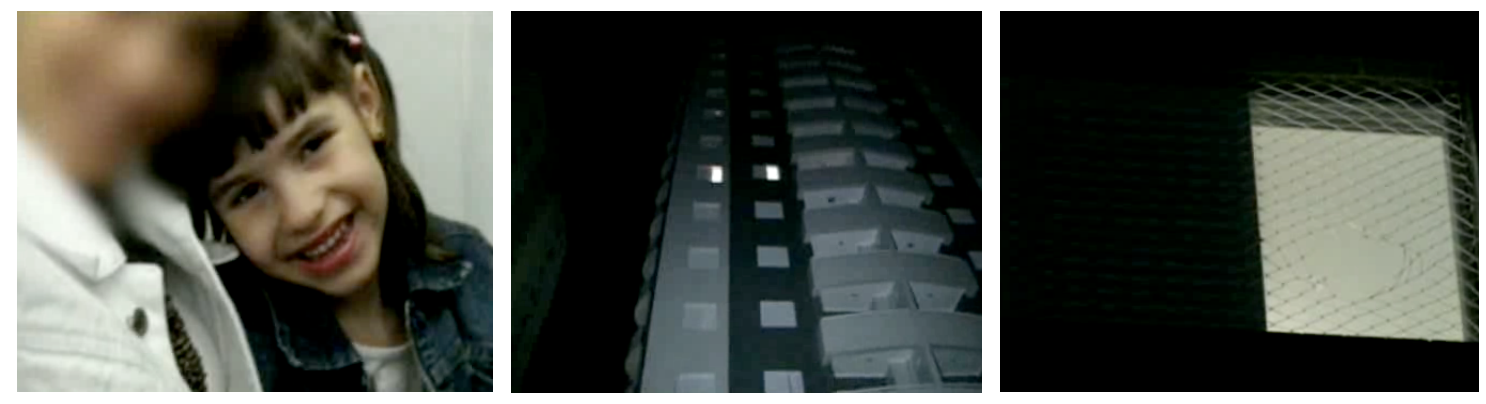

Nos quadros a seguir, vê-se a reprodução computadorizada da versão do pai: 

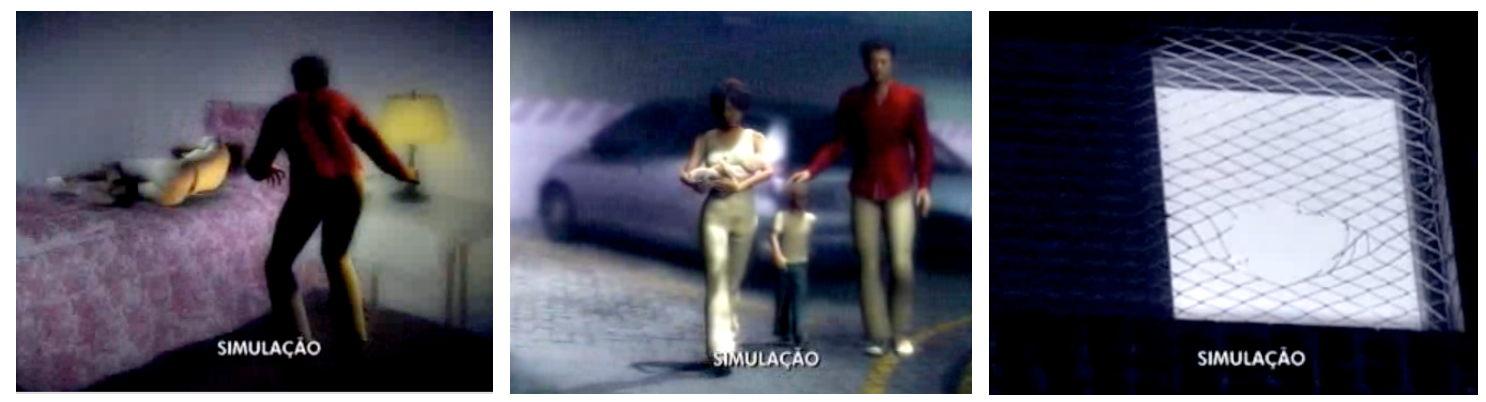

Audiovisualmente, o enunciador "Jornal Nacional" configura o primeiro panorama do crime $^{54}$. Uma menina bonita, de classe média, brutalmente assassinada por um alguém ainda a se determinar: um fait divers, segundo Barthes (1964); um fato semiótico que bruscamente invade o campo de presença do sujeito, nos termos de Zilberberg (2011a).

A segunda reportagem sobre o caso, exibida em 01/04/2008, narra: “A janela de onde, segundo a polícia, a menina foi jogada, está sem a tela de proteção, levada pelos peritos". Nesse momento, a câmera capta, em zoom, a imagem da janela, conforme se vê a seguir:
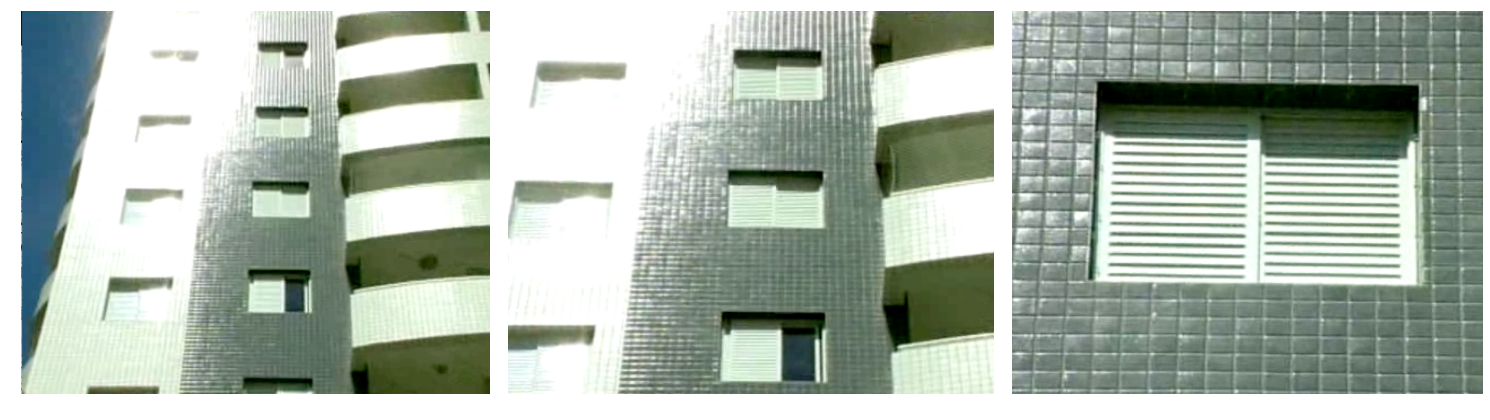

\footnotetext{
${ }^{54} \mathrm{Um}$ telejornal é, como se sabe, um texto audiovisual. Entretanto, devido a escolhas metodológicas que impõem algumas coerções à análise, tomaremos como sinônimos os termos audiovisual e verbovisual, uma vez que não fazemos referência a elementos como entoação da fala, linguagem musical, etc.
} 
Pela posição da câmera, a partir do chão, o enunciatário pode perceber a altura de que Isabella caiu. Em seguida, diz o repórter: "No prédio, ninguém fala para onde foram o pai de Isabela [sic], a mulher e os dois filhos [...] Foi do sexto andar do prédio que Isabela [sic], de cinco anos, caiu no sábado à noite". Em outra tomada, também em zoom, mostra-se de forma mais detalhada a altura do prédio e, por conseguinte, o enunciatário consegue perceber a amplitude da queda. No terceiro quadro, aparece com nitidez o lugar do crime, que, de edificação qualquer, passa a ser um local muito conhecido pelo público: o Edifício London.
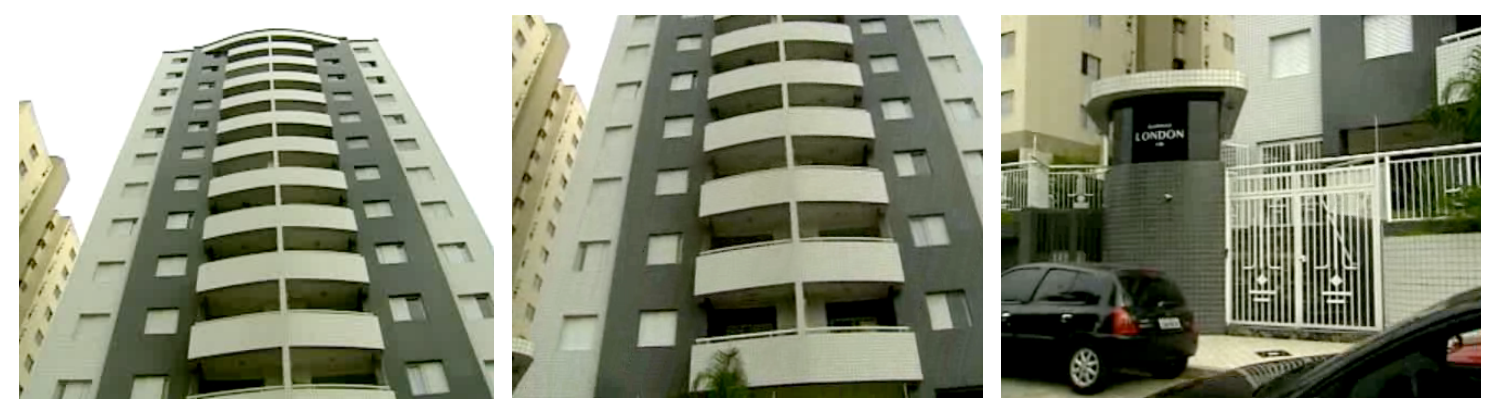

Na segunda reportagem, narra-se novamente a versão de Alexandre Nardoni e se exibe a mesma simulação computadorizada do dia anterior. Esse fato entra em consonância com o que Gomes (2012) chama de acontecimento reverberado, pois, apresenta-se praticamente a mesma notícia. Tensivamente, isso pode ser explicado como uma demanda de temporalidade do sujeito semiótico (enunciatário) para absorver o impacto do acontecimento. Repete-se praticamente o mesmo conteúdo com o intuito de o sujeito apreender aquele fato ainda fulgurante.

A reportagem termina falando sobre Ana Carolina Oliveira: 
A mãe de Isabela [sic] ainda não prestou depoimento. Mas, numa página de relacionamentos na internet, agradeceu a solidariedade dos amigos. Também escreveu uma mensagem para Isabela. "Filha maravilhosa da minha vida, você será eterna. Lutarei para conquistar tudo nessa vida em "nosso nome'. Te amarei para sempre!".

Concomitantemente à fala do repórter, a imagem da página de Ana Carolina Oliveira na rede social destaca estes enunciados:

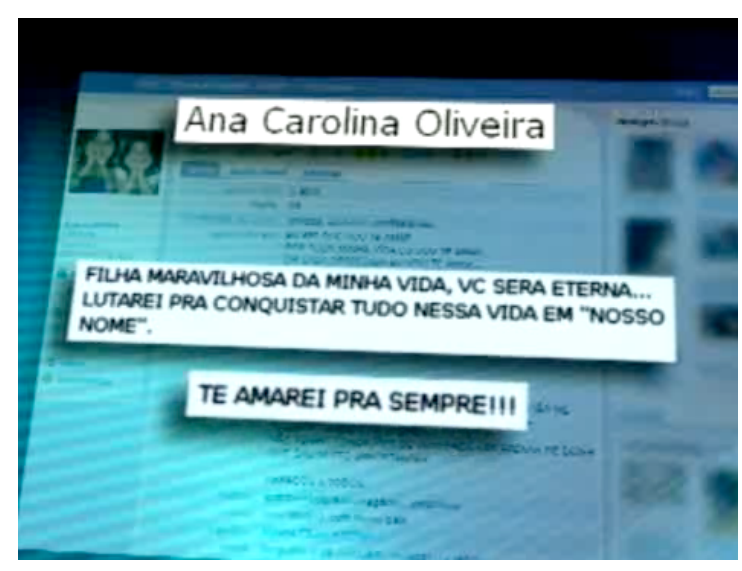

Conforme dissemos, a primeira reportagem sobre o caso, em termos tensivos, é portadora de um alto grau de intensidade. O relato audiovisual em foco reverbera, mas também faz irromper microacontecimentos. Para nós, tanto uma coisa quanto a outra configuram práticas impregnantes (TATIT, 2010). Utilizamos o termo do semioticista aqui com um viés um pouco distinto, pois, segundo a análise do autor, tais práticas impregnantes referiam-se à mesma visão que o filho tinha do pai na canoa. Aqui, essa pregnância pode se referir ao acontecimento motivador ou a microacontecimentos. Conforme dissemos, tanto o acontecimento 
reverberado quanto os microacontecimentos cumprem a função de afetivar cada vez mais o campo de presença do sujeito.

Assim, pelas reportagens, vão se agregando novos elementos verboicônicos: uma tela de proteção rasgada, a altura do prédio, o rosto de uma menina cuja beleza é considerada eufórica, o depoimento de Ana Carolina Oliveira, mãe de Isabella, declarando seu amor pela filha. Cada pequeno detalhe é pregnante. É como se extasiasse o sujeito que ainda pouco consegue elaborar além do fato de que aquela criança fora violentamente assassinada.

Segundo a reportagem exibida em 02/04/2008:

Nesta quarta-feira, a mãe de Isabella esteve na delegacia. A chegada foi tumultuada. Ana Carolina Oliveira veio prestar depoimento acompanhada dos pais. [...] Ana Carolina ficou três horas na delegacia. Segundo a polícia, ela traçou um perfil sobre o relacionamento com o pai de Isabella e disse como eram os encontros do pai com a filha. Na saída, ela não quis comentar o depoimento. "Já dei minha declaração. Que a justiça seja feita", ela disse aos jornalistas.

A seguir, podem-se ver a chegada e a saída tumultuadas de Ana Carolina Oliveira da delegacia: 

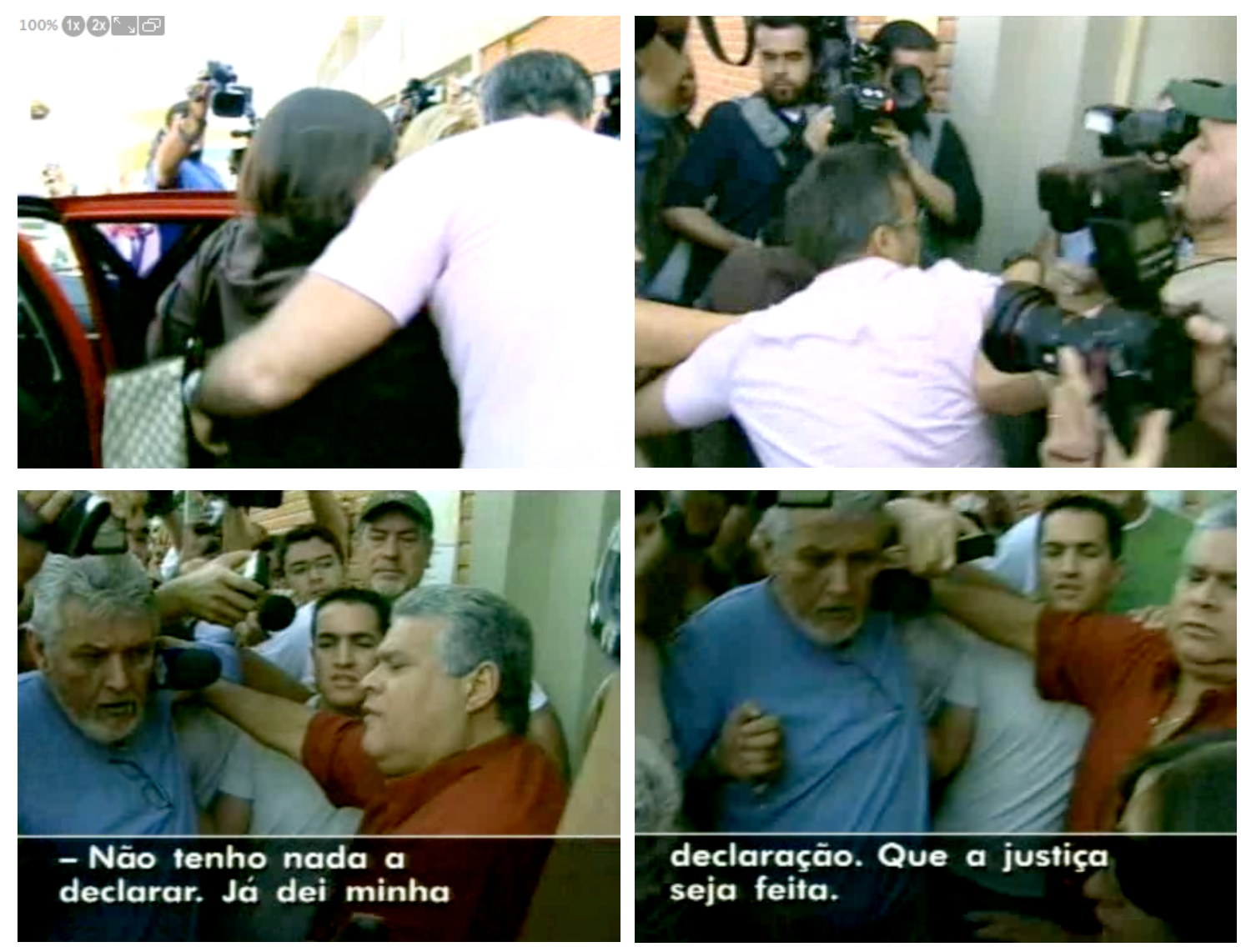

O tumulto, a concentração de jornalistas em volta da mãe de Isabella, a quem quase não se pode ver, - tonicidade e andamento altos - atrelado ao fato de a câmera manter um enquadramento fechado, delimita o campo de presença do sujeito, fecha-o, intensificando a carga afetiva do relato visual.

Pelos elementos até agora expostos, não seria razoável supor que uma semiótica que se debruça fundamentalmente sobre o aspecto sensível da significação prescindisse do componente visual. Juntamente com o verbal, a linguagem visual contribui para dar densidade sêmica máxima ao Caso Isabella Nardoni: "Somos o real", diria Barthes (2012, p. 190). Retomando ainda a citação de $\operatorname{Ramos}(2012$, p. 50), "O fait divers se compatibiliza com a 
linguagem televisiva". Nesse sentido, o audiovisual constitui, com som e imagem em movimento, o figurativo, que é levado ao paroxismo por meio da iconização do fait divers ${ }^{55}$. No substrato tensivo deste, a intensidade, inicialmente alta, tende a aumentar com o passar do tempo. Assim, as práticas impregnantes a que se refere Tatit (2010) tocam, afetam, por meio do sincretismo dessas linguagens, o sujeito "telespectador", cujo campo de presença se vê em crescente processo de ampliação da intensidade.

Vejamos em outras reportagens como isso pode ser também verificado. No dia 03/04/2008, foram exibidas três reportagens sobre o Caso Isabella Nardoni. Na primeira delas, o apresentador William Bonner afirma: "Depois de um dia inteiro de expectativa, foram presos na tarde desta quinta, em São Paulo, o pai e a madrasta da menina Isabella Nardoni. O repórter César Tralli tem os detalhes" (itálicos nossos). O trecho narrado pelo jornalista motiva no sujeito telespectador uma espera tônica, o que, em termos tensivos, contribui para a manutenção de um campo de presença com cada vez mais mais. Segue a fala do repórter:

O momento em que o casal se entrega aos policiais: os dois, pai e madrasta, saem do carro de um dos advogados. Primeiro, o pai, Alexandre Alves Nardoni, depois, a madrasta, Anna Carolina Jatobá. Eles são colocados dentro do carro oficial de um dos diretores da polícia e do fórum de Santana partem para a delegacia.

Nos quadros a seguir, mostra-se, numa tomada aérea, o momento em que Alexandre Nardoni e Anna Carolina Jatobá saem de um carro vermelho e entram na viatura policial:

\footnotetext{
${ }^{55}$ Nesta pesquisa, analisado por meio de frames/quadros.
} 

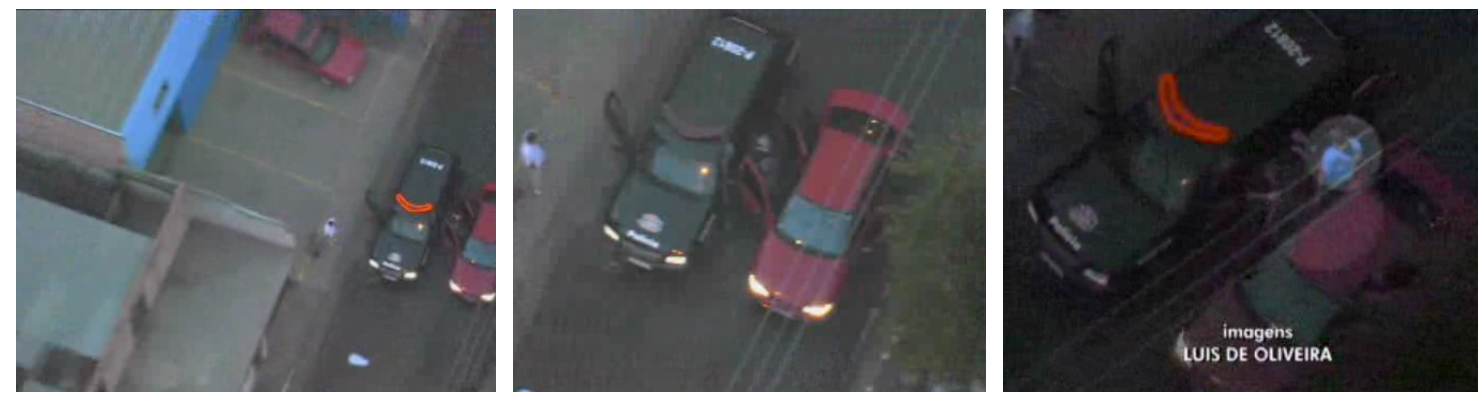

Aqui, em relação a essa sequência de imagens, nota-se que a aproximação pelo zoom da câmera também fecha o campo de presença: isso conduz a uma intensidade crescente, pelo fechamento contínuo do espaço.

Na mesma reportagem, é narrado o seguinte trecho: "Todo o material recolhido, em seis dias de investigação, está no Instituto de Criminalística. Na quarta [feira], pela terceira vez, os peritos voltaram ao prédio. Da janela de onde Isabela [sic] caiu, tiraram fotos". Nas imagens seguintes, observa-se, com a mesma estratégia de aproximação da câmera, uma perita que fotografa a partir da janela de onde a criança fora arremessada:
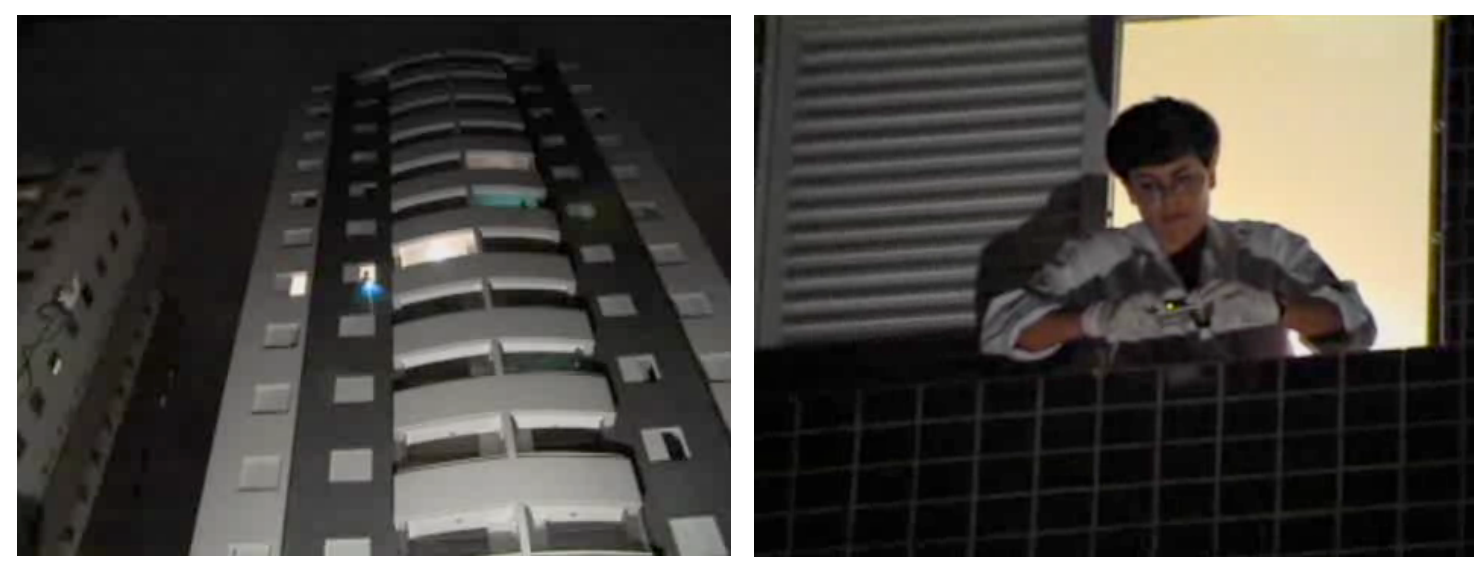
Noticia-se ainda: "Usaram uma boneca para tentar reproduzir em que posição a menina foi encontrada no jardim”. Pelos quadros que se mostram a seguir, o visual aqui dramatiza o verbal - em duas acepções: tanto no que se refere à representação [mise en scène] quanto no que tange a um quantum afetivo que se liga ao verbal, intensificando, assim, o relato audiovisual:
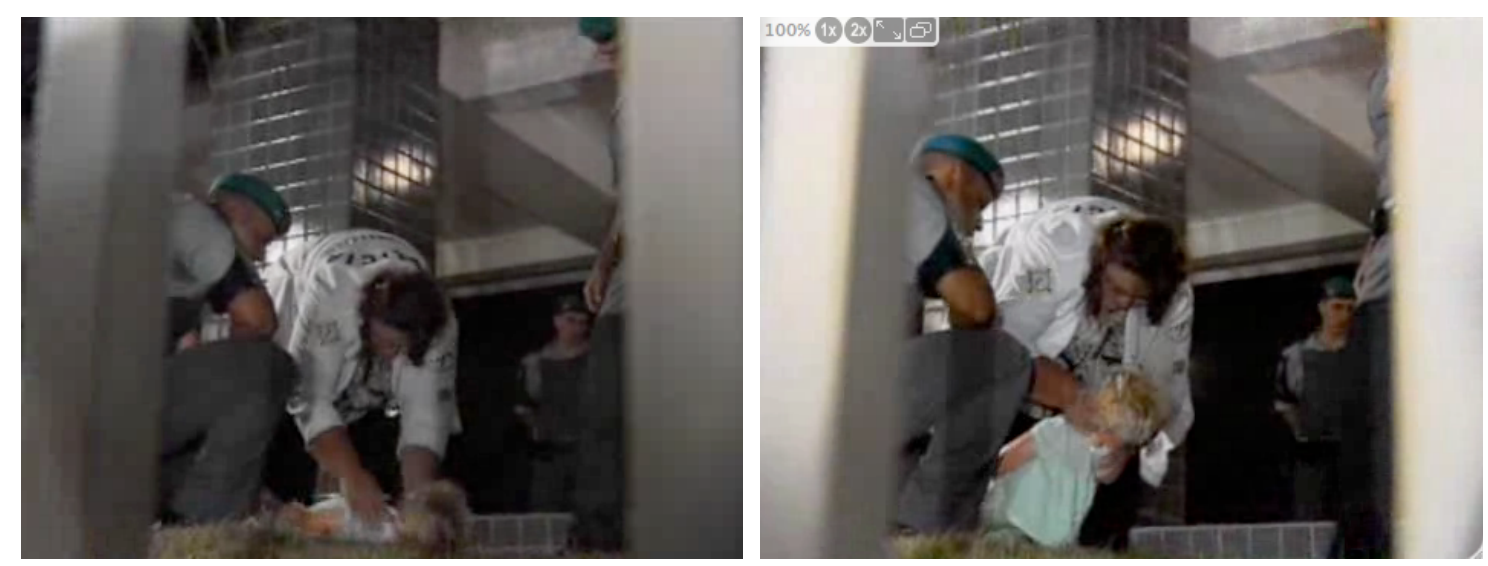

Segue o texto da reportagem:

Com equipamentos sofisticados, procuraram dentro do apartamento vestígios de fios de cabelo e fibras de tecido e aplicaram um produto químico que ajuda a identificar manchas de sangue imperceptíveis a olho nu. [...] O Instituto de Criminalística decidiu tirar o DNA de gotas de sangue encontradas no lençol para comparar com o sangue de Isabella.

Pela simulação computadorizada exibida a seguir, o Jornal Nacional, de forma didática, explica o procedimento da perícia para encontrar gotas de sangue. 


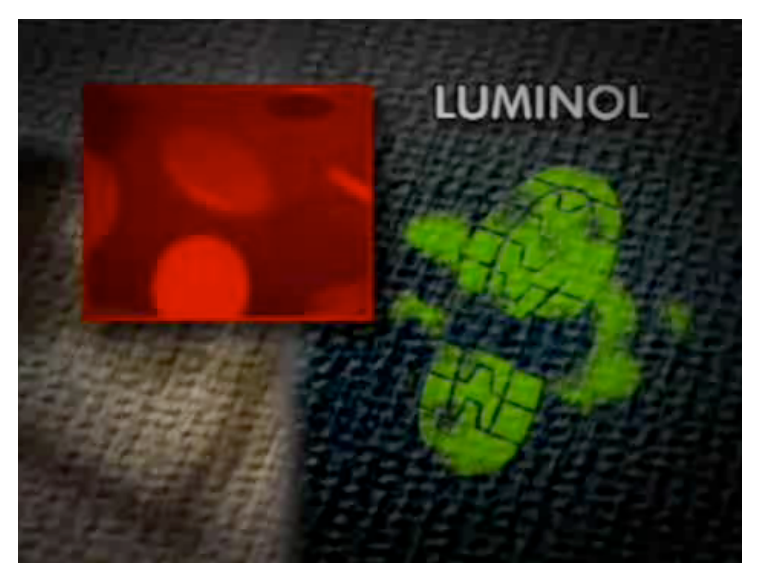

À esquerda, num quadro vermelho, observa-se o que se supõe ser o sangue humano observado em nível microscópico. À direita, em verde, uma pegada de sangue que reagiu em contato com o produto químico luminol, citado no quadro acima. A tentativa de explicar o acontecimento, de digerilo, lança mão desse tipo de estratégia.

Apresenta-se um último trecho da reportagem:

A perícia já confirmou que a tela de proteção da janela foi cortada com uma tesoura. Na noite da morte da menina, uma tesoura foi apreendida no apartamento. Peritos também acharam, em outro apartamento que fica no mesmo prédio e que pertence à irmã de Alexandre, roupas que ele usava no sábado. O mesmo juiz, que na quarta decretou a prisão do casal Nardoni, também determinou sigilo nas investigações.

Os indícios descritos acima permitem ainda depreender um provável envolvimento de Alexandre Nardoni na morte da própria filha. Assim, nesta como as reportagens anteriores, observa-se uma contínua tonificação do campo de presença do sujeito. 
Na segunda reportagem exibida pelo Jornal Nacional na edição de 03/04/2008, o apresentador William Bonner afirma: “A comoção provocada pela morte de Isabella tomou o Brasil e se tornou um dos principais assuntos das conversas, tanto nas ruas quanto na internet". Segue a fala do repórter:

Isabella, a menina sorridente que aparece num vídeo divulgado nesta quinta na internet faria seis anos daqui a duas semanas. As fotos foram reunidas pelo namorado da mãe, Ana Carolina Oliveira, em uma homenagem à menina.

As imagens seguintes mostram partes do vídeo exibido na reportagem, contendo fotos de Isabella:
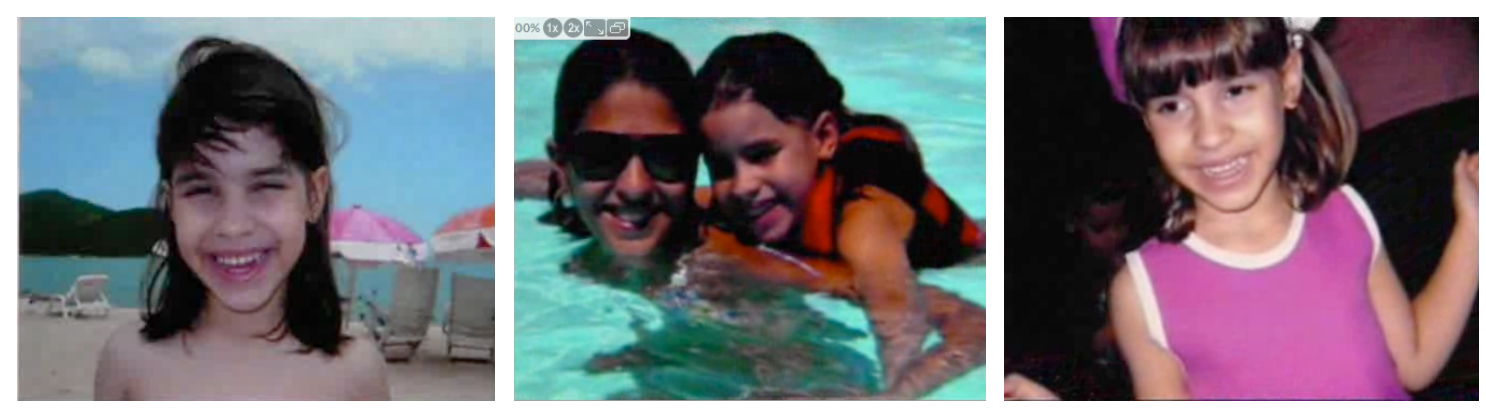

O repórter declara:

Isabella estudava numa escola da Zona Norte de São Paulo havia pouco mais de um ano. Ela estava no pré. A mãe de um coleguinha que conhecia bem Isabella diz que todos estão chocados pela morte brutal. Ela conta qual é a imagem da menina que ficará na memória. "Ela era linda, sorridente" (itálicos nossos). 
No trecho em itálico, reafirma-se o estado de choque em que "todos" se encontravam por causa da morte de Isabella ${ }^{56}$. Assim, em termos informativos, essa reportagem pouco ou nada tem a acrescentar sobre as causas da morte da criança. Entretanto, conforme Gomes (2012), tais elementos configuram uma reverberação do acontecimento para que o sujeito dê conta de converter, graças à temporalidade, o sensível em inteligível.

Pelo que se analisou até agora, os relatos noticiosos sobre o caso dividem-se em duas categorias (as quais podem estar presentes numa mesma reportagem ou não): as que reverberam o acontecimento e aquelas que trazem novos elementos - os microacontecimentos - como nos conveio chamar aqui.

Assim, o sujeito semiótico (enunciatário) se vê impelido a desempenhar duas funções contrárias: tanto absorver o impacto do acontecimento inicial quanto estarrecer-se a cada novo desdobramento do caso. E, enquanto novos fatos surgirem, a absorção do impacto torna-se impossível de ser levada a cabo, em função da constante reativação do campo de presença. Tal operação antagônica, dessa maneira, mantém alta a intensidade do Caso Isabella Nardoni - apesar do transcurso do tempo.

Uma das reportagens exibidas em 04/04/2008 ilustra as duas categorias a que nos referimos. Inicialmente, o acontecimento reverberado, quando o Jornal Nacional noticia a missa de sétimo dia de Isabella:

\footnotetext{
${ }^{56}$ Cabe acrescentar que esse estado de comoção social será ainda tema de análise neste capítulo (item 3.2.3).
} 
Amigos e parentes lotaram a Igreja Nossa Senhora da Candelária na zona norte de São Paulo. Ana Carolina Oliveira e a família vestiam uma camiseta com a foto da menina e a mensagem: 'Isabella, nossa estrelinha para sempre'.

As imagens a seguir exibem a celebração religiosa:
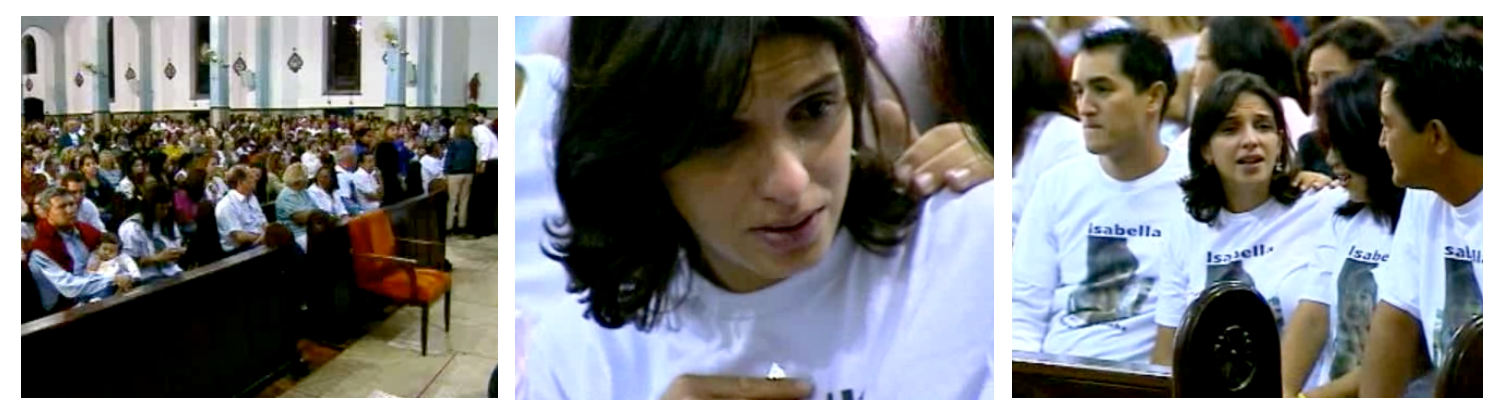

No primeiro quadro, veem-se, em plano aberto, os presentes na igreja. O segundo, em close, mostra o semblante abalado da mãe de Isabella; no terceiro, pode-se ver Ana Carolina Oliveira, com a mesma expressão facial de tristeza, ao lado de amigos e parentes. A cobertura da missa de sétimo dia de Isabella corresponde, em termos tensivos, à reverberação do acontecimento motivador.

Por outro lado, na mesma reportagem, observam-se dois microacontecimentos. O primeiro diz respeito à versão "fantasiosa", nos termos do promotor Francisco Cembranelli, acerca do que depuseram pai e madrasta de Isabella. O segundo relata a existência de dois boletins de ocorrência envolvendo Alexandre Nardoni. Transcreve-se o trecho da reportagem: 
O Ministério Público duvida da versão apresentada pelo pai e pela madrasta de Isabella. O promotor Francisco José Cembranelli que acompanha o caso afirma que existem contradições entre o que dizem os suspeitos e as testemunhas. Por exemplo, os horários em que o casal chegou ao prédio, em que Alexandre teria subido até o apartamento e descido depois. "Existem muitos trechos bastante fantasiosos, difíceis de se concretizar. Num primeiro momento, quando eles desceram e havia toda aquela movimentação pra tentar tirar a menina dali, pessoas ouviram ele dizer que havia um ladrão na casa e provavelmente a porta havia sido arrombada por um ladrão. Depois, no depoimento, isso não é mencionado em nenhum momento e a perícia, claro, vai apresentar a conclusão de que não havia sinal de arrombamento" [afirma o promotor]. [... Mais tarde, em uma nova entrevista, o promotor Francisco José Cembranelli disse que a investigação deve levar em conta dois outros boletins de ocorrência que envolvem Alexandre Nardoni e Anna Carolina Jatobá. Um deles foi registrado pela mãe de Isabella em 2003. Segundo o documento, Alexandre não aceitava que a filha freqüentasse [sic] uma escolinha e chegou a fazer ameaças de morte à excompanheira.

Assim, tanto a versão "fantasiosa" aludida pelo promotor de justiça um argumento de autoridade, conforme já se mencionou - quanto o conteúdo do boletim de ocorrência revelam dois microacontecimentos. (1) O magistrado crê que o casal está envolvido no crime; (2) Alexandre Nardoni possuía antecedentes que corroboram sua possível participação no assassinato da filha.

Desse modo, uma mesma reportagem pode tanto reverberar o acontecimento inicial quanto fazer irromper novos microacontecimentos relativos ao primeiro. 
Em outra reportagem exibida em 04/04/2008, novos microacontecimentos se apresentam. A prisão em delegacias distintas de Alexandre Nardoni e Anna Carolina Jatobá, cuja imagem em computação gráfica detalha verbovisualmente os cômodos em que estão detidos: "cela individual, cama, colchão e banheiro", além da presença do promotor no apartamento onde houve o crime: "No fim da tarde, o promotor que cuida do caso foi ao apartamento de Alexandre Nardoni acompanhado de delegados. Ele quer conhecer o local para acompanhar melhor os próximos passos da investigação". Os quadros mostram, em sequência, cada um dos elementos novos apresentados na notícia:
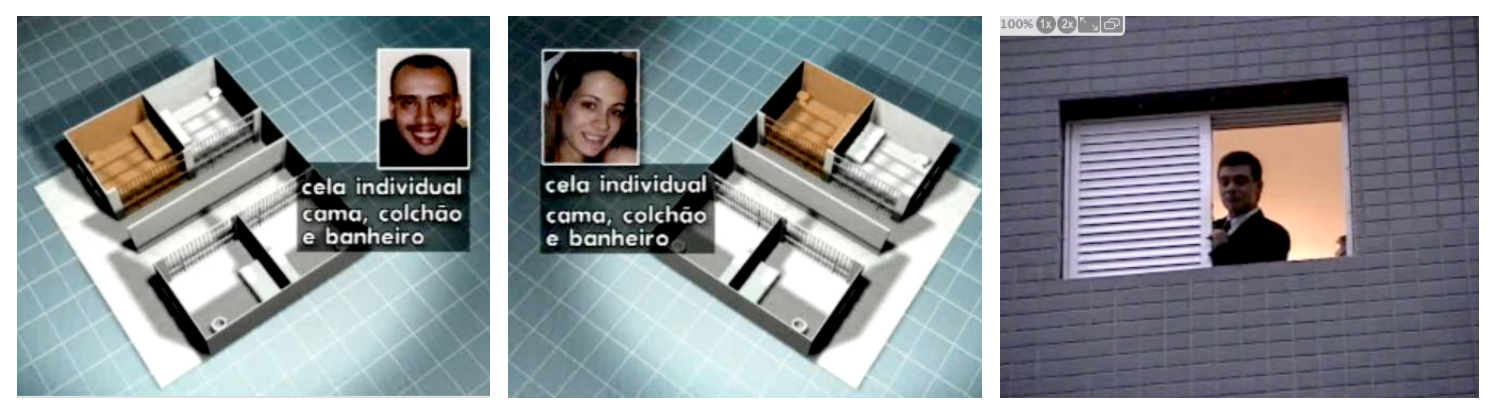

A terceira reportagem exibida na edição do Jornal Nacional de 04/04/2008, cuja manchete é "Esclarecendo a prisão temporária", mostra a entrada tumultuada de Alexandre Nardoni e Ana Carolina Jatobá, conforme exibido a seguir. Esses planos são marcados por um espaço fechado, devido ao enquadramento da câmera, um andamento acelerado, pela movimentação de muitas pessoas - policiais e jornalistas sobretudo - no entorno, e forte tonicidade que a imagem carrega: o momento em que os então suspeitos são detidos em prisão temporária: 

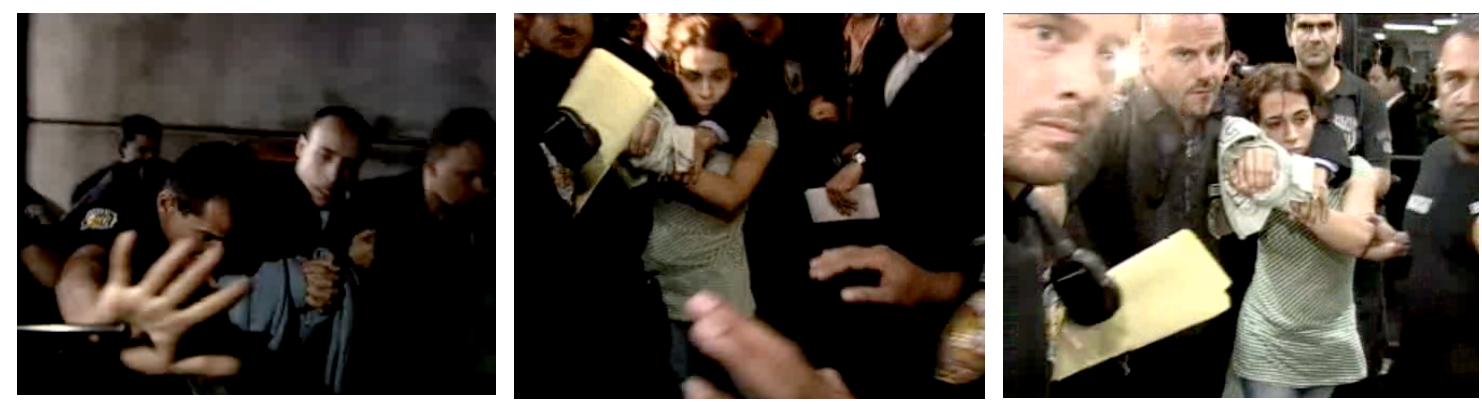

A despeito das imagens marcadas por um forte quantum afetivo, a reportagem visava a explicar por que pai e madrasta de Isabella Nardoni haviam sido presos. No quadro a seguir, vê-se, em computação gráfica, o trecho da lei que prevê esse tipo de medida cautelar:

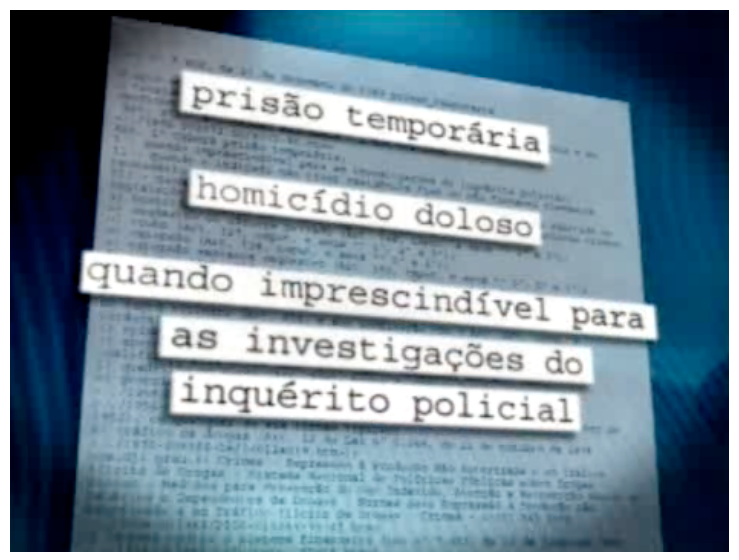

Assim, se, visualmente, parte da reportagem é marcada por um forte impacto, a temática do verbal "esclarecer a prisão temporária do casal" refere-se ao contraprograma que se impõe ao acontecimento cujo objetivo é compreender, tornar inteligível, o que ainda se encontrava no limiar do discurso. 
Na edição do dia seguinte, em uma entrevista por telefone, Ana Carolina Oliveira afirma: "Demore o tempo necessário para que encontre o culpado e que tenha justiça mesmo". Ao lado da declaração da mãe de Isabella, a foto da criança sorrindo:

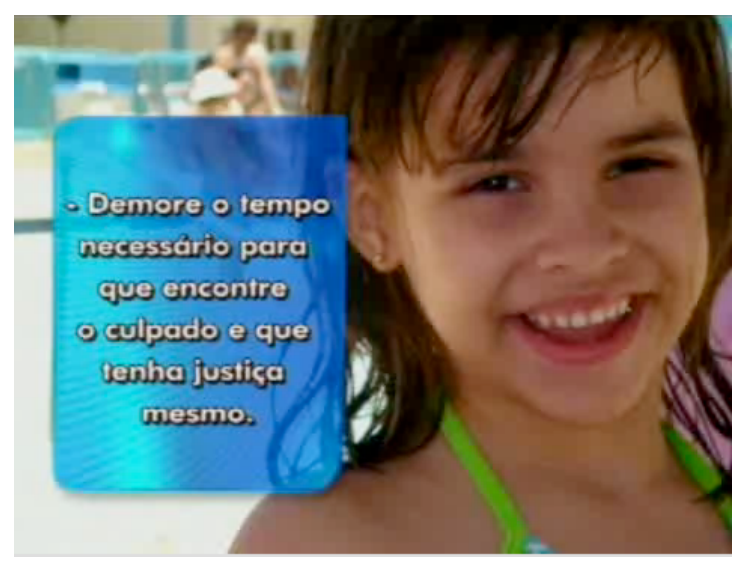

Veiculado de forma reiterativa, o rosto da criança impõe-se no campo de presença do sujeito (enunciatário), configurando uma prática impregnante. A associação do visual à temática de um crime hediondo estabelece-se através de uma sobreposição de sentidos: a imagem de Isabella, uma criança bonita, conforme os padrões axiológicos vigentes, e as circunstâncias monstruosas de seu assassinato. Essa outra prática reverbera o acontecimento, mantendo em um alto grau a intensidade com o passar do tempo.

Ainda em 05/04/2008, outro microacontecimento se apresenta: "Peritos confirmaram que foi mesmo encontrado sangue em um lençol e na maçaneta da porta de entrada do apartamento". Da mesma forma, em 07/04/2008, o trecho mostra outros elementos que contribuem para afetivar o campo de presença do sujeito: 
A polícia tenta refazer os passos de Alexandre Nardoni e Anna Carolina Jatobá na noite em que Isabella morreu. Para isso, conseguiu a quebra do sigilo telefônico do casal, para saber com quem eles conversaram antes e depois da queda da menina do sexto andar. [...] Existe mais uma pista que pode levar a quem matou Isabella. Uma pegada encontrada em um lençol dentro do apartamento do casal. Para fazer uma comparação com a marca, policiais apreenderam no fim de semana 30 pares de sapatos que pertencem a Alexandre Nardoni e Anna Carolina Jatobá. Os calçados ainda serão encaminhados para a perícia.

Instaura-se nesse sujeito uma espera tônica, conforme foi objeto de análise na subseção anterior. O próximo trecho, de caráter ainda mais intenso, descreve as circunstâncias da morte de Isabella, de acordo com os peritos.

Peritos da Polícia Civil de São Paulo ainda não podem afirmar quem cometeu o crime, mas sabem que foi uma ação extremamente violenta. [...] Com base nas provas técnicas, os peritos concluíram: o assassino de Isabella de fato arremessou a menina pelo buraco da rede e, no momento da queda, ela estava desmaiada. Segundo a perícia, Isabella foi jogada de ponta cabeça, tanto que as marcas das mãos dela ficaram logo abaixo da janela, na fachada do prédio. O corpo se descolou da parede e caiu no gramado do jardim, o que amorteceu o impacto. A queda provocou uma fratura. Na parte de trás da bacia, como a perícia constatou. A outra fratura, no pulso esquerdo, de acordo com os peritos, foi provocada antes da queda. Assim como o corte de dois centímetros na testa, por onde Isabella perdeu muito sangue. Ainda segundo os peritos, a menina apresentava sinais típicos de asfixia: manchas no pescoço e na nuca, outras manchas avermelhadas no pulmão e língua projetada para frente. 
Notadamente, os fatos narrados no excerto anterior cumprem a função de trazer novos elementos que ainda se desconheciam. Esses microacontecimentos promovem a direção ascendente do discurso, por meio da categoria do recrudescimento. A reportagem de 09/04/2008 destaca uma entrevista com a delegada que dirigia as investigações:

"Não tem um depoimento que se destaca em relação aos demais, mas sempre eles estão se complementando, sempre um dando credibilidade ao outro, sempre um corroborando o outro", declarou a delegada Renata Helena Pontes. [Ela] disse que já está perto de montar toda a cena do crime. "A gente já tem $70 \%$ referente à dinâmica, ao ferimento, aonde [sic] que aconteceu, enfim, tudo o que foi feito lá dentro até o final, até o óbito" (itálicos nossos).

Pelo trecho acima, o enunciatário "telespectador" intensifica o estado de espera cuja resolução parece ser cada vez mais próxima: uma espera cada vez mais tonificada. Em 10/04/2008, outro fato novo se apresenta:

A polícia espera esclarecer dados ainda obscuros na investigação com a quebra do sigilo telefônico de parentes de Isabella. O primeiro telefonema para o serviço de resgate foi às 23 horas, 49 minutos e 59 segundos daquele sábado, dia 29 de março. Era um de um morador do prédio, que pedia socorro para a menina Isabella. Outras duas ligações se seguiram para os bombeiros, segundo a polícia, todas de vizinhos. [...] Ainda segundo a polícia, ao mesmo tempo em que os vizinhos pediam ajuda, o telefone fixo do apartamento do casal era usado para duas ligações: uma, às 23 horas, 50 minutos e 32 segundos para o pai de Ana Carolina, a madrasta. Durou 32 segundos. E outra, às 23 horas, 51 minutos e 9 segundos para o pai de Alexandre, o advogado Antonio Nardoni. Durou 29 segundos (itálicos nossos). 
Quando a reportagem se refere ao telefonema feito do apartamento de Alexandre Nardoni, pode-se ver a janela, com a tela de proteção rasgada. $\mathrm{O}$ segundo e o terceiro quadros, que fazem alusão à chamada telefônica de Anna Carolina Jatobá para o pai dela, são marcados por uma tarja com os respectivos horário e duração. Aquele mostra, por um afastamento da câmera, o Edifício London. Este, por sua vez, a imagem da suspeita, em meio a muitos repórteres, policiais e pessoas comuns.
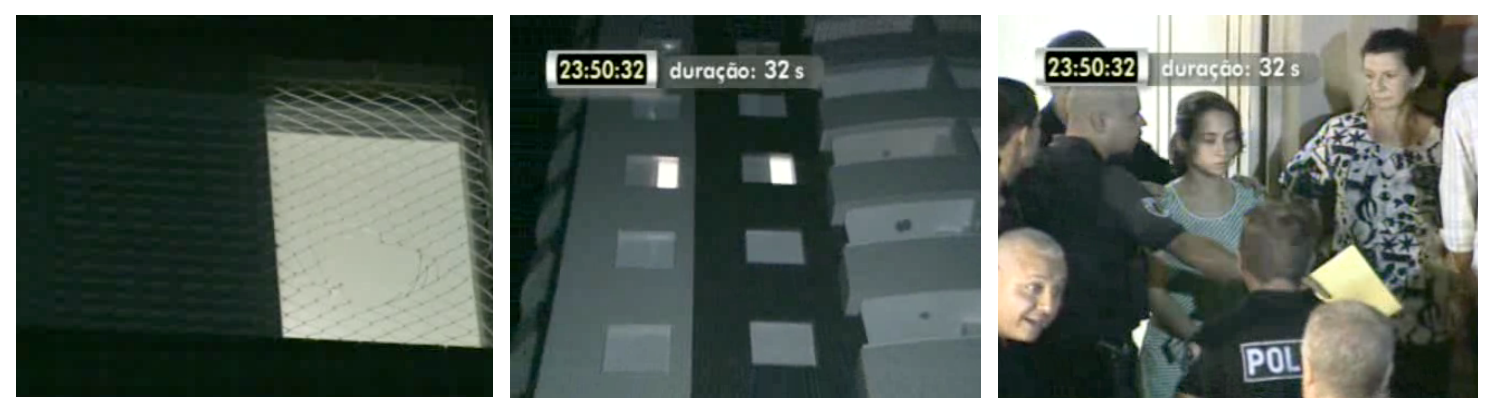

Pelo verbal e pelo visual, o enunciatário pode depreender os seguintes efeitos de sentido: (1) é, no mínimo, estranho que os dois telefonemas feitos a partir do apartamento de Alexandre Nardoni tenham sido feitos para o pai de Ana Carolina Jatobá e, em seguida, para o pai de Alexandre Nardoni, e não para a polícia ou para o corpo de bombeiros, como seria de se esperar. (2) Houve três chamadas solicitando socorro todas de vizinhos; nenhuma realizada pelo número de telefone do apartamento em que houve o crime. (3) As imagens corroboram essa desconfiança - pela exibição da tela de proteção da janela, que reitera o local de onde Isabella fora lançada - e, em seguida, pela imagem da suspeita rodeada de policiais. Em 15/04/2008, a delegada que dirigia as investigações afirma: "Esse comportamento incomum revela, quiçá, que ambos já sabiam 
que nada mais tinham a fazer para salvar a vida da criança, necessitando, naquele momento, de proteção paterna para eles próprios” Dessa forma, o enunciador "Jornal Nacional” reforça um crer-ser, ainda que não soubesse-ser.

Como se mencionou na Introdução, o Caso Isabella Nardoni foi pauta de não uma, mas de até quatro reportagens na mesma edição do Jornal Nacional durante o período recortado pela pesquisa. Assim, pelo menos durante as 36 edições do Jornal Nacional circunscritas pelo corpus, pôde-se acompanhar o desenrolar do caso, que, a nosso ver, constitui-se de fundamentalmente dois tipos de textos noticiosos: os que reverberam o acontecimento (Cf. GOMES, 2012) e aqueles que fornecem novos elementos sobre o crime, os quais passamos a denominar "microacontecimentos". Em ambos os casos, estabelece-se uma prática impregnante (Cf. TATIT, 2010), que intensifica, pela reiteração, cada vez mais o campo de presença do sujeito semiótico (enunciatário), a despeito da passagem do tempo. Temos, assim, elementos que nos autorizam afirmar que a duração do Caso Isabella Nardoni motivou um aumento contínuo da carga tímica do fato semiótico em análise.

Cabe salientar ainda que essa passagem de tempo é textualmente reiterada pelo Jornal Nacional. Em 05/04/2008, por exemplo, o noticiário afirma: "Uma semana depois da morte da filha de 5 anos [...]" (itálicos nossos). Em 09/04/2008, noticia-se: “Desde a morte de Isabella, 11 dias atrás” (itálicos nossos). Em 14/04/2008, observa-se: "Dezesseis dias depois de Isabella ter sido jogada do sexto andar" (itálicos nossos). Em 18/04/2008, reporta-se: "Vinte dias depois da morte de Isabella Nardoni” (itálicos nossos). Em 23/04/2008, por sua vez: "Em 25 dias de investigação, a polícia já ouviu 64 pessoas: 62 na condição de testemunhas e duas como suspeitas: Alexandre Nardoni e Anna 
Carolina Jatobá” (itálicos nossos). Em 26/04/2008, vê-se um trecho semelhante: "Na próxima terça-feira (29), vão completar 30 dias que Isabella Nardoni morreu" (itálicos nossos). Assim, a duração do caso apoia-se, inclusive, em marcadores temporais.

Concomitantemente, como já foi mostrado, veem-se afirmações tais como em 12/04/2008: “A verdade, segundo a polícia, está cada vez mais perto". Em 15/04/2008, por seu turno, narra-se: "Laudo da perícia deve ser entregue até a próxima sexta”. Essa tonificação da espera se liga à intensidade que se projeta sobre a duração: eis novamente o efeito de persistência, como exposto na subseção analítica anterior.

Continuemos a análise com o fito de ratificar as invariantes até agora destacadas. Em 15/04/2008, mostra-se o colchão com uma gota de sangue supostamente de Isabella, antes de ser atirada pela janela. Em seguida, apresenta-se o gramado em que a menina caiu.
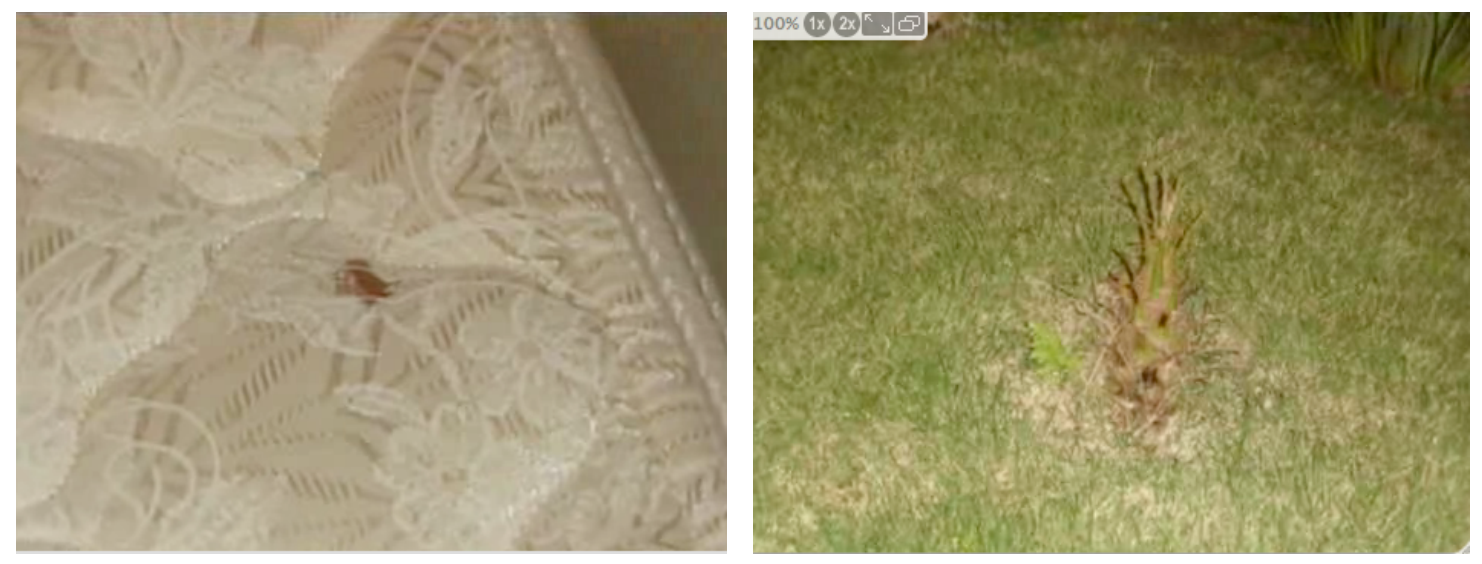

Essas imagens cumprem o papel de reverberar o acontecimento, cujo efeito é manter sua intensidade em nível elevado. Na mesma reportagem, apresentam-se depoimentos de "testemunhas [que] afirmam que as brigas 
entre o pai e a madrasta de Isabella eram violentas e freqüentes [sic]". Na montagem, a seguir, pode-se ler o depoimento de uma das testemunhas:

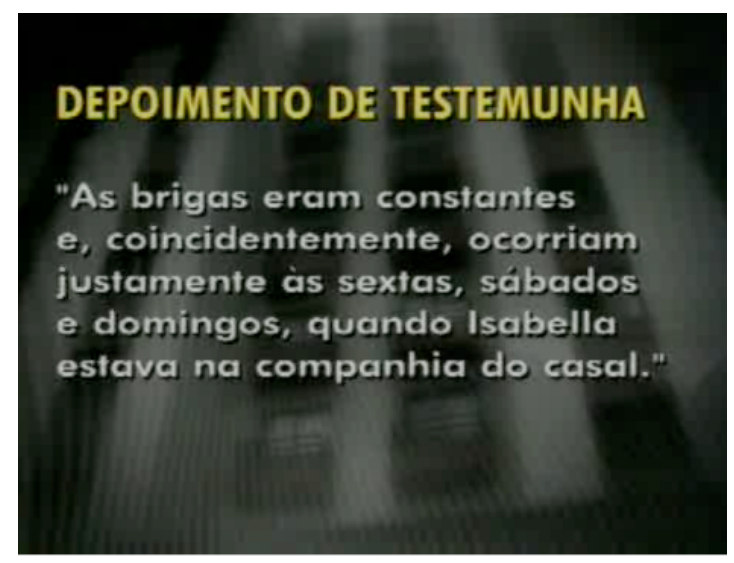

Tal informação não configura um fato novo, uma vez que, em outros depoimentos, a relação conturbada do casal foi tema de relato de outras testemunhas. Assim, tem-se, agora, um efeito de reverberação, não do acontecimento motivador do Caso Isabella Nardoni, mas de um microacontecimento. Ainda na mesma reportagem, a delegada descreve o suposto temperamento desequilibrado de Anna Carolina Jatobá, como pode ser visto a seguir no primeiro quadro. Já no segundo, a policial se refere à certeza de ter havido um crime, conforme pode também ser lido nas imagens que seguem: 

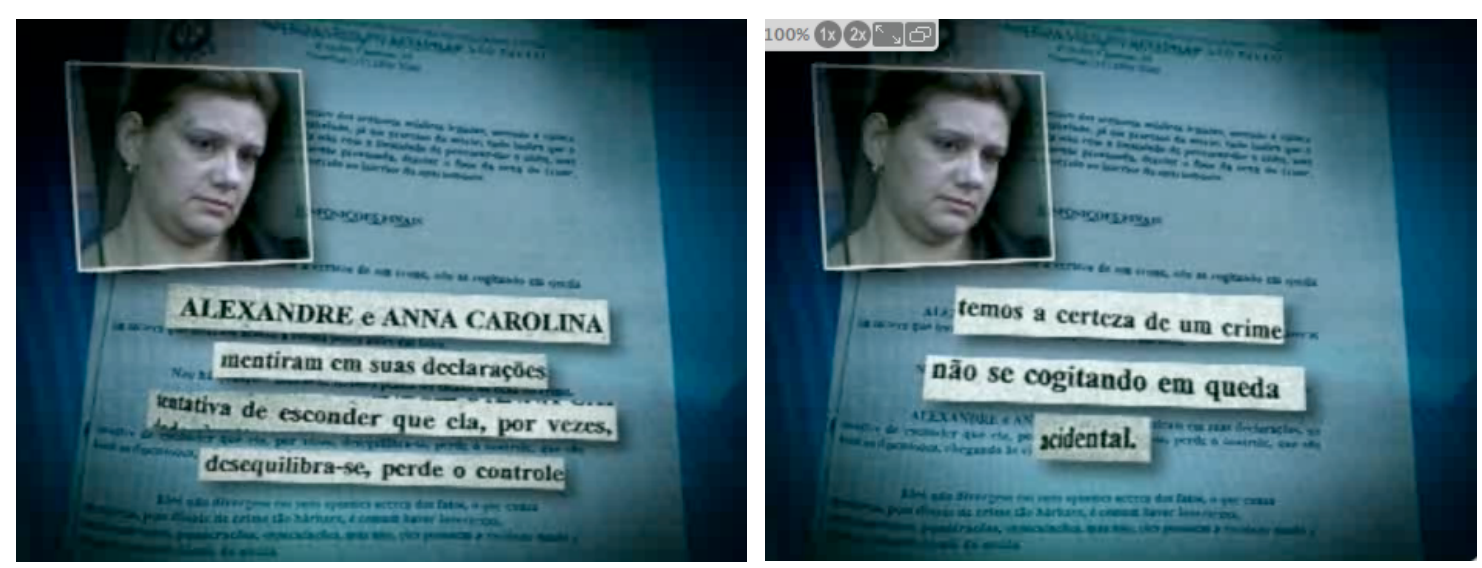

Outra reportagem exibida naquela mesma edição do Jornal Nacional afirma: "Os exames feitos depois de Isabella ter sido jogada pela janela mostraram que ela tinha marcas no pescoço, manchas no pulmão e no coração. As pontas dos dedos também estavam avermelhadas, sinais de asfixia”. Sincronicamente à narração do repórter, apresenta-se, em simulação computadorizada, a descrição minuciosa do estado de Isabella antes de ser arremessada pela janela, cujo caráter é tão didático quanto chocante, ainda que se trate de uma imagem com menor grau de figuratividade:
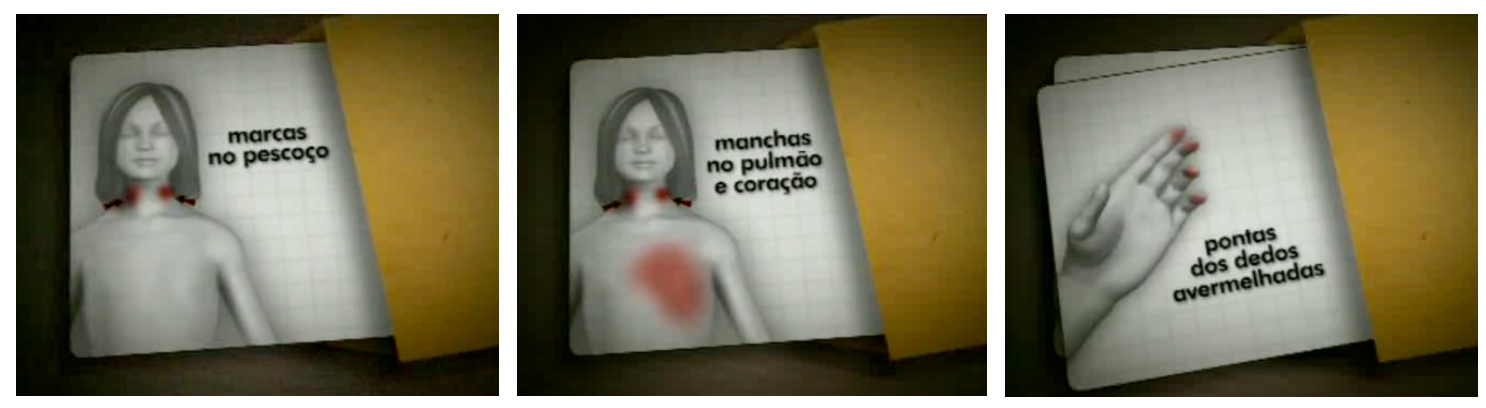

Numa terceira reportagem na mesma edição, a então apresentadora do noticiário, Fátima Bernardes, afirma: 
O Jornal Nacional exibe uma entrevista exclusiva com duas pessoas que a polícia de São Paulo considera testemunhaschave na investigação do assassinato de Isabella Nardoni. Um casal que mora em um prédio vizinho ao edifício onde ocorreu o crime $[\ldots]$ Os dois já depuseram à polícia e adiantaram que repetirão, em juízo, tudo o que relataram nesta reportagem.

Segue a reportagem: "Na noite do assassinato de Isabella, um casal ouviu uma violenta discussão que vinha de outra janela, quase em frente. $O$ quarto de Alexandre Nardoni e Anna Carolina Jatobá”. No quadro a seguir, veem-se ambas as testemunhas de costas, à janela do quarto destes, cuja vista frontal dava para a sacada do quarto de Alexandre Nardoni e Anna Carolina Jatobá:

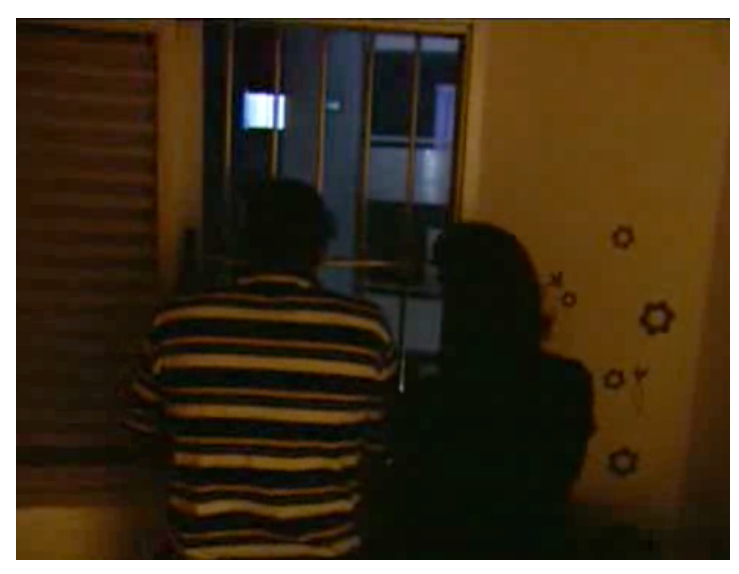

Segundo narrou a mulher,

Em discussões, apareciam uma pessoa da voz feminina principalmente e a voz masculina pouco se ouvia. Praticamente nada. Mas a voz feminina ficou muito marcada devido às palavras de baixo calão que se pronunciavam. Eram muitos palavrões. Não era uma briga típica de casal. Era uma briga de desespero. [...] Essa discussão foi questão 
de uns cinco minutos. Acho que não passou disso e, logo em seguida, veio o silêncio. Esse silêncio durou aproximadamente uns 10 minutos.

O marido, por sua vez, afirmou:

Ao me aproximar dela [de Isabella Nardoni], eu vi que os olhos dela estavam abertos, arregalados, a boquinha entreaberta, manchada de sangue e praticamente desfalecida no chão. Ela tinha o cortezinho na testa, mas não transparecia que estava sangrando nem nada. Parecia que estava limpo. O rosto estava limpo. Na hora que eu ia tocar nela pra ver a pulsação da Isabella, eu virei e dei atenção ao pai que saía do saguão do prédio. Ele olhou para mim e disse que tinha uma pessoa armada no apartamento dele, que estava no sexto andar, e que o cara tinha jogado a filha dele $[\ldots]$ ", revela o vizinho do casal Nardoni.

Pelos depoimentos acima, nota-se que a declaração da mulher referese à reverberação de um microacontecimento já apontado: o relacionamento conflituoso de Anna Carolina Jatobá e Alexandre Nardoni. A afirmação do marido remete à reverberação do acontecimento motivador do Caso Isabella Nardoni. Ressalte-se que, pela descrição minuciosa, altamente figurativa, do estado em que Isabella se encontrava no gramado do Edifício London ("os olhos dela estavam abertos, arregalados, a boquinha entreaberta, manchada de sangue e praticamente desfalecida no chão.") recria-se discursivamente uma cena dramática, cujo caráter intenso é patente. Assim, esse constante "reviver do acontecimento" contribui para que a morte da criança se mantenha no campo de presença do sujeito (enunciatário).

Em 18/04/2008, o noticiário assevera: "O casal Alexandre Nardoni e Anna Jatobá prestou novos depoimentos e a polícia decidiu indiciá-los pelo 
assassinato da menina Isabella”. Na reportagem do dia seguinte, observa-se o trecho: "O trabalho dos peritos permitiu que a polícia montasse o que chama de 'dinâmica do crime': a sucessão dos fatos naquele sábado, 29 de março". Como esse trecho já foi transcrito na seção analítica anterior, mostraremos apenas as imagens em computação gráfica realizadas pelo Jornal Nacional, com base na reconstituição dos peritos:
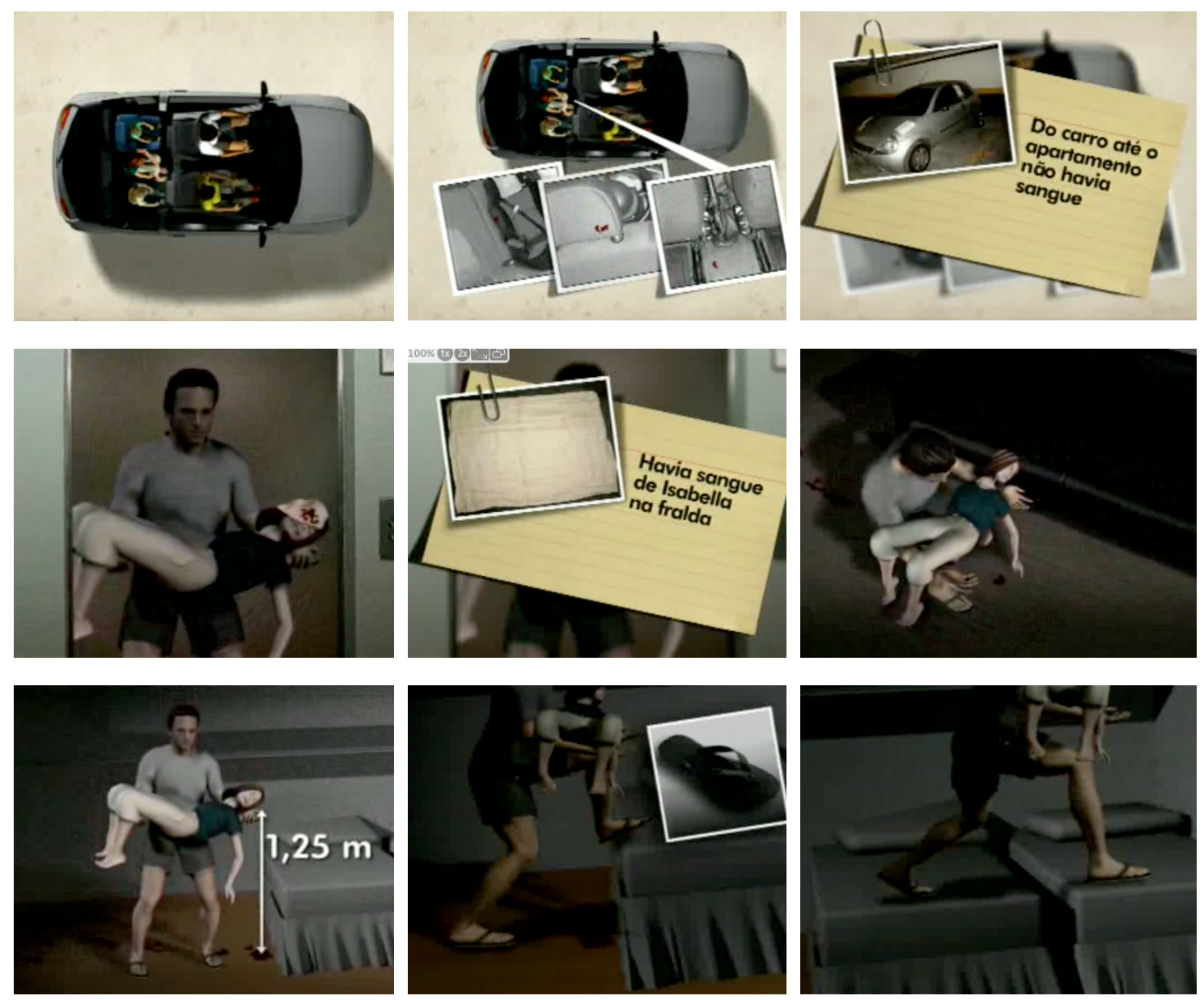

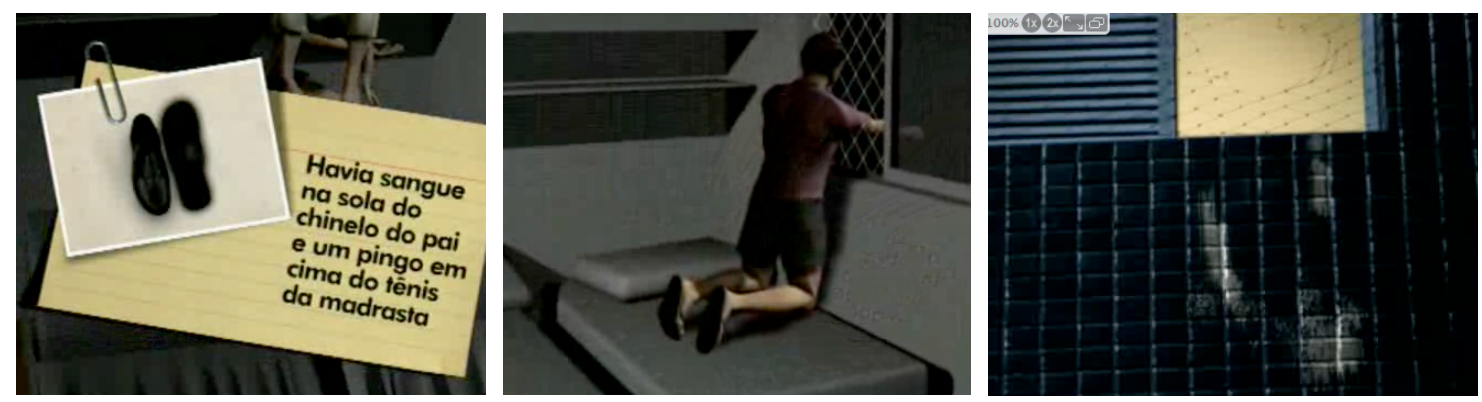

Aqui cabe uma observação: o discurso acerca do Caso Isabella Nardoni construiu-se tanto pelo contraste entre os depoimentos quanto pelos indícios obtidos pela perícia e pelas inferências dos responsáveis pela investigação. Nesse sentido, a determinação dos culpados é claramente de natureza veridictória.

A sequência de imagens feitas por computação gráfica acima convergem depoimentos em linguagem visual e, mais uma vez, frise-se, o efeito é tão didático quanto monstruoso. Ademais, a sucessão de ações que antecederam o lançamento da menina pela janela constitui um microacontecimento, uma vez que tais elementos, em termos informativos, agregam conteúdo em relação àquelas circunstâncias até então desconhecidas. E, ressalte-se mais uma vez, a cada irrupção de um novo desdobramento, o sujeito tentando, via temporalidade, atenuar a intensidade do acontecimento, vê seu campo de presença novamente tonificado pelos novos fatos que surgem.

Em 21/04/2008, o Jornal Nacional noticia:

Os legistas concluíram que, mesmo antes de ser jogada, Isabella estava condenada à morte pela esganadura que tinha sofrido. Pelo relato dos legistas, é possível concluir que 
Isabella foi esganada dentro do apartamento. O principal indício é o fato de que a menina ainda estava viva quando bateu no gramado. Isso indica que a asfixia aconteceu minutos antes. De acordo com os legistas, se o intervalo entre a esganadura e a queda fosse maior, a menina já teria chegado morta ao solo.

A imagem de computação gráfica, exibida de forma concomitante, sentencia a causa mortis de Isabella:

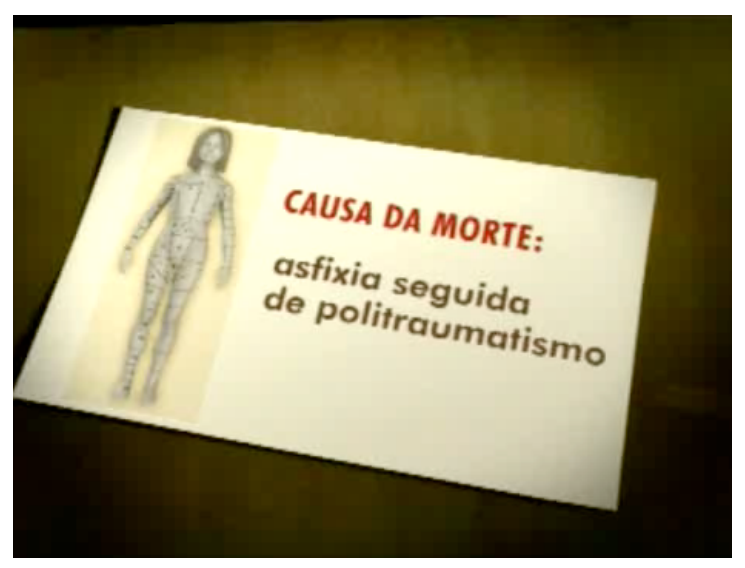

Ao enunciatário, assim, cabe concluir que antes de ter sido jogada pela janela, a criança sofrera esganadura: uma morte mais cruel do que se imaginava. Como se vê, em termos tensivos, o campo de presença do sujeito é continuamente tonificado.

Em 25/04/2008 o Jornal Nacional divulga “cópias dos depoimentos de Alexandre Nardoni e Anna Jatobá. Nos documentos, há detalhes da investigação que a polícia mantinha em sigilo e que surpreenderam o casal”. Segundo a reportagem: 
Uma das provas mais importantes [era a] camiseta que Alexandre usava no dia crime, [na qual] peritos encontraram vômito de Isabella. Questionado se sua camiseta encontravase suja, Alexandre respondeu que não. Ele foi então informado sobre a constatação de vômito de Isabella na camiseta e não soube explicar como isso aconteceu.

Assim, por meio do confronto entre o depoimento do pai de Isabella e das provas periciais, vão-se, discursivamente, construindo as circunstâncias do assassinato.

Em 28/04/2008, o Jornal Nacional mostra a reconstituição do crime, em que foi usado um boneco forense de porte parecido ao de Isabella. Segundo a reportagem, "o momento mais dramático foi a encenação da queda da menina”. Na primeira simulação, o perito solta o boneco por uma mão e depois pela outra; numa segunda, ele solta as duas mãos ao mesmo tempo. Em outro momento da reconstituição, o boneco é colocado no gramado do Edifício London. A seguir, veem-se as imagens da primeira simulação:
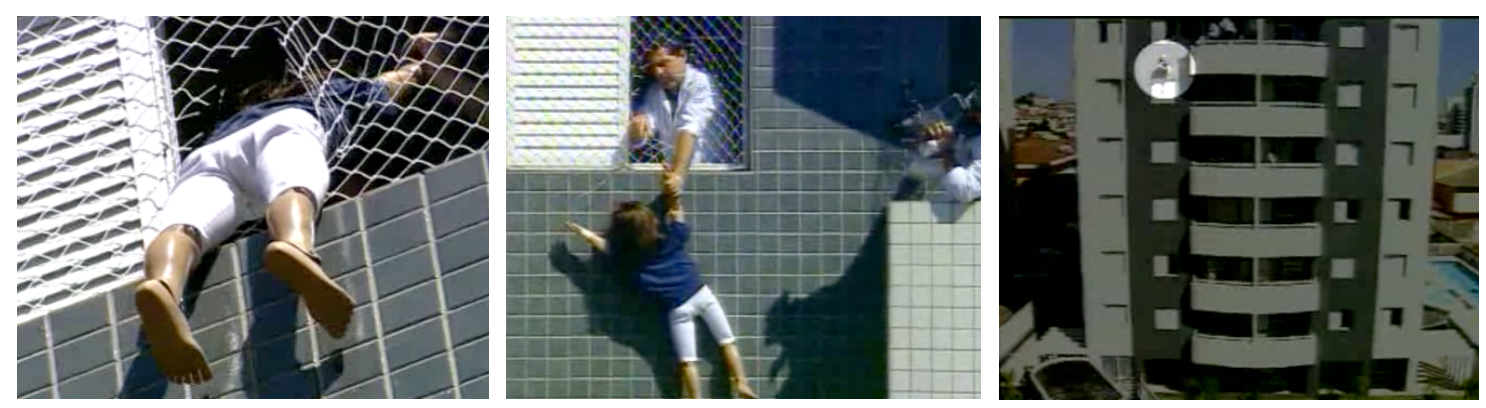

Na sequência, observam-se os quadros que mostram o boneco sendo jogado pela janela e, a seguir, caído sobre o gramado do Edifício London: 

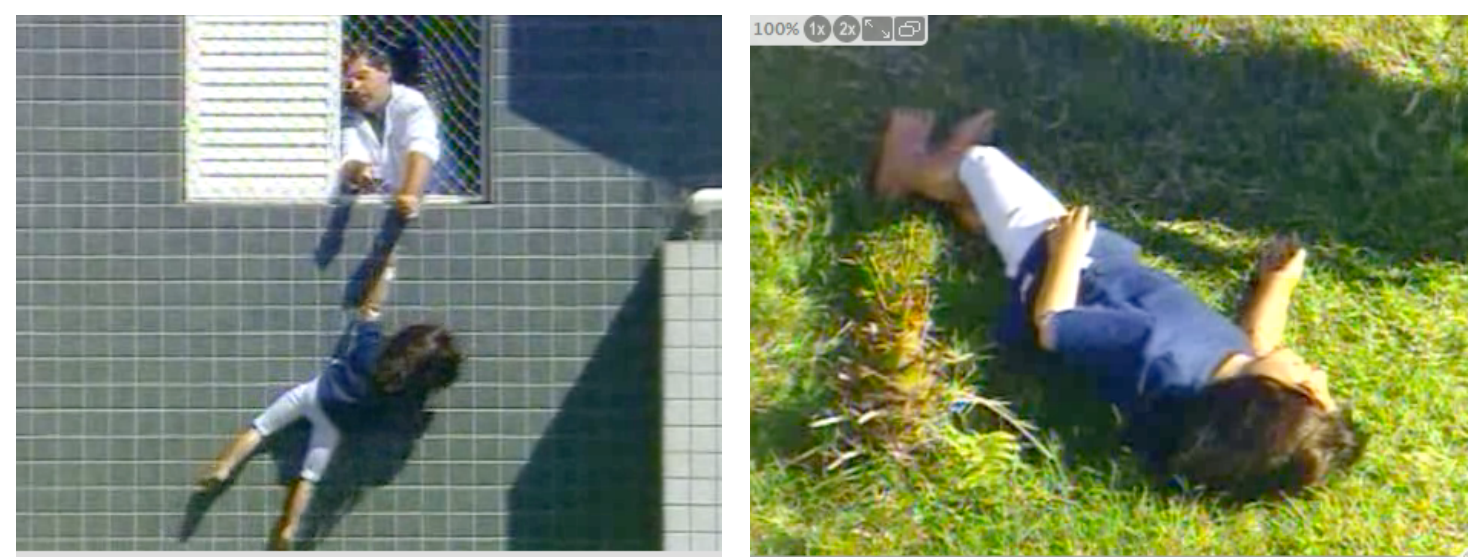

Assim, pelo que se pode ver nas imagens, por mais que se tratasse de uma reconstituição, a presença de um boneco forense com a mesma compleição física de Isabella confere densidade sêmica àquelas imagens: é, por assim dizer, um quase-real assustador, aterrorizante. Não por acaso, vimos insistindo na ideia do aumento da intensidade do Caso Isabella Nardoni ao longo do período recortado pelo corpus.

Acerca da linguagem visual, é importante salientar ainda que o enunciador "Jornal Nacional" faz uso muito mais corrente da iconização para reconstituir a morte de Isabella a partir do ponto de vista da acusação do que da defesa do casal suspeito. Apenas uma simulação computadorizada se refere à versão de Alexandre Nardoni, segundo a qual, uma terceira pessoa teria sido o autor da morte de Isabella. Por outro lado, utilizam-se muito mais frequentemente imagens (simulações gráficas computadorizadas, simulações com bonecos,) que indicavam participação de Alexandre Nardoni e Anna Carolina Jatobá como possíveis autores do crime. Isso retoma, de certo modo, a questão epistêmica da subseção anterior, pois, por meio das 
imagens, intensifica-se um crer-ser, ainda que não se soubesse-ser de forma efetiva.

O casal que tivera sua prisão preventiva decretada fora solto por meio de habeas corpus. O desfecho do caso já foi tratado na subseção anterior: depois disso, Alexandre Nardoni e Anna Carolina Jatobá foram denunciados e, em seguida, presos, conforme narra uma reportagem exibida em 08/05/2008:

Depois de quatro horas de decretada a prisão preventiva, as primeiras imagens do casal [...]. Na garagem do edifício, ele [Alexandre Nardoni] foi algemado, com as mãos para trás, e levado para um dos carros da polícia. Logo atrás, também Anna Carolina Jatobá, também algemada. Eles foram transportados como criminosos comuns, na parte de trás dos carros.

Nas imagens que seguem, podem-se ver Alexandre Nardoni e Anna Carolina Jatobá, cada qual numa viatura policial, sendo conduzidos a penitenciárias distintas:
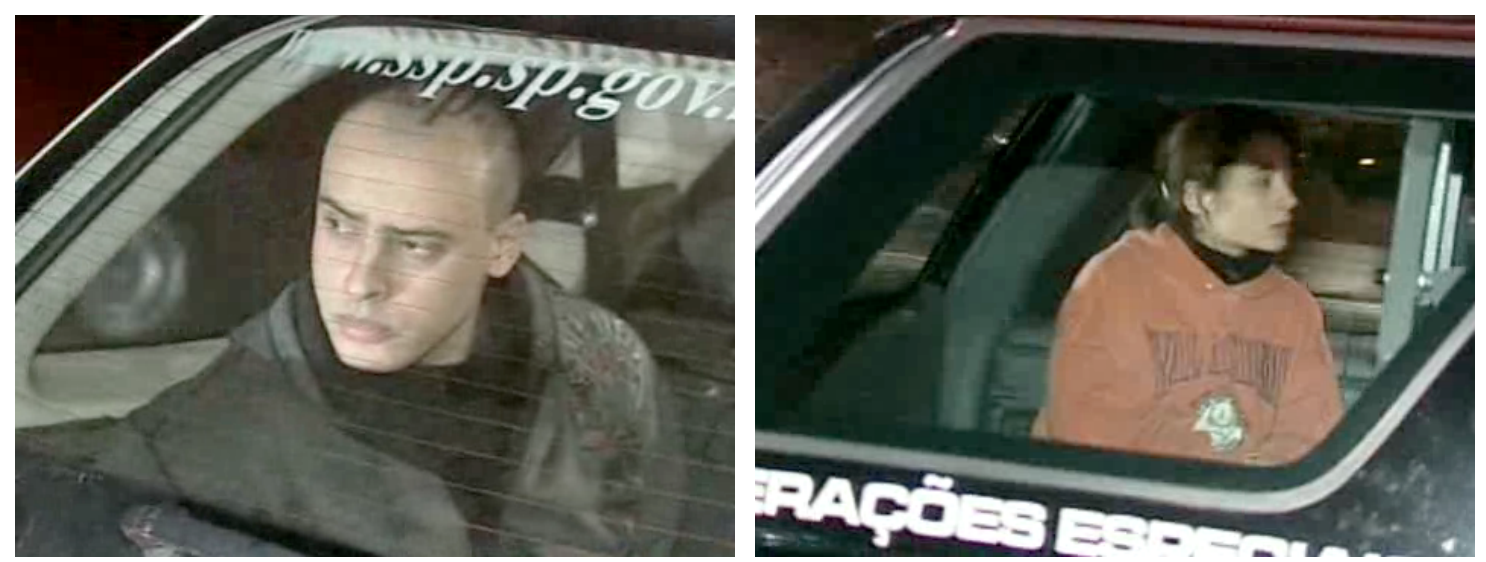
Pelo relato audiovisual, essas imagens remetem à "sanção pragmática" aplicada aos autores do crime "sujeitos do fazer", de acordo com o laudo policial.

Interessa-nos, neste momento, a partir dos elementos expostos, resgatar os pontos principais da análise realizada na presente subseção. Vimos que uma das razões pelas quais o Caso Isabella Nardoni durou remetem a duas categorias noticiosas: (1) aquela que reverbera o acontecimento da morte da criança; e (2) aquela que, por trazer elementos desconhecidos acerca do crime, denominamos microacontecimentos. Observamos ainda que estes também são passíveis de reverberação. Em vista disso, postulamos que o sujeito semiótico (enunciatário) vê-se obrigado a desempenhar duas funções antagônicas: atenuar a intensidade (em específico a tonicidade) do Caso Isabella Nardoni, por meio da temporalidade, ao mesmo tempo em que, à sua revelia, o mesmo acontecimento reverbera e, sobretudo, irrompem novos microacontecimentos. Por isso, esse fato semiótico teve uma intensidade crescente, mesmo com o passar do tempo, apesar de maioria dos faits divers, segundo Barthes (1964), não possuir duração nem memória.

Cabe dizer, de forma complementar, que as práticas impregnantes configuram-se também, no caso em estudo, pelo sincretismo verbovisual. Desse modo, o Caso Isabella Nardoni tem uma função pregnante, afetivante, que tonifica, via recrudescimento, cada vez mais o campo de presença do sujeito semiótico.

Somente, entretanto, com a detenção do pai e da madrasta de Isabella (conforme mostram as últimas imagens exibidas) - a sanção pragmática -, a 
saturação do campo de presença tende a ser, enfim, gradativamente atenuada.

Assim, podemos afirmar que o Caso Isabella Nardoni configura-se como um acontecimento global, que se constitui do acontecimento motivador, dos microacontecimentos que lhe seguiram e de suas respectivas reverberações. O acontecimento global se conclui somente com a perda da intensidade em relação ao caso, o que implicou, por essa razão, uma vasta extensidade. Por isso, para o sujeito semiótico (enunciatário), o acontecimento global só se conclui - eclode, produz-se, realiza-se por completo - após essa considerável extensão temporal: eis, portanto, a pregnância, a "gestação” do acontecimento que está “prenhe” de si mesmo.

Vemos, por conseguinte, com clareza, a maneira como elementos do nível tensivo ressoam nos demais patamares de organização do sentido. Desse modo, o modelo tensivo, por meio de seus conceitos primordiais de afetividade e continuum, apresenta-se como um aparato teórico-metodológico vigoroso, que, em combinação com as estruturas narrativas e discursivas do percurso gerativo greimasiano, dá sustentação à análise de textos como o caso aqui enfocado.

\subsubsection{Comoção, paixão coletiva}

O terceiro eixo que conduz nossa análise diz respeito a uma paixão que perpassa todo o Caso Isabella Nardoni: a comoção. A razão disso é que eventos midiáticos de grande repercussão são marcados por afetos que 
mobilizam um actante coletivo ${ }^{57}$. Este se refere, no caso em análise, a um todo quase-indiferenciado - o público - que, graças a um sentir e a um sofrer comuns, funde o "muitos" em uma unidade actancial.

A respeito da ideia de uma paixão coletiva, obtemos respaldo no pensamento de Greimas e Fontanille (1993, p. 202), que afirmam:

A "convivialidade" seria uma paixão coletiva comunitária; $e$ se aceitarmos fazer da "opinião pública” um sujeito apaixonado, ela pode estar no quadro das paixões coletivizantes, sejam elas comunitárias ou identitárias. Enfim, as paixões do sujeito coletivo integral são aquelas pelas quais todo um grupo determina sua identidade: "a consciência de classe" seria uma delas, mas também todas essas paixões nacionais que, conforme sejam captadas do exterior ou do interior, podem passar ora por estereótipos gastos, ora por fermentos de identidades coletivas (itálicos nossos).

Fontanille e Zilberberg (2001, p. 301) falam em paixões de caráter exclusivo (como o ciúme) e paixões de caráter participativo. As primeiras tendem aos valores de absoluto; as segundas, por seu turno, aos de universo. Vejamos como a comoção se insere nas paixões desse segundo grupo.

Ela é definida pelo Houaiss como: "emoção forte e repentina $<$ sentiu comoção violenta ao ver a amiga inanimada ; agitação, alvoroço, revolta popular, levantamento, agitação social < a comoção ganhou as ruas>”. Comoção vem do verbo comover, que, pela mesma fonte, significa: "mover

\footnotetext{
${ }^{57}$ Greimas e Landowski (1976, p. 96-99) concebem o "actante coletivo" como indivíduos que partilham com outros um certo papel temático. Nesse estudo, os autores analisam o actante coletivo das sociedades comerciais, conceito que podemos trazer para a esfera midiática - o enunciatário da mídia - pois tal actante é suscetível de individuação, ao mesmo tempo em que se funde num todo. Salientam os autores que o actante coletivo é subsumido pela figura do(s) ator (es) também coletivo(s).
} 
fortemente, agitar com força; deslocar; causar ou sofrer emoção viva ou subitânea; impressionar-se; provocar ou sentir enternecimento; fazer perder ou perder a dureza de alma".

Assim, a comoção pode ser individual, mas, queremos ressaltar seu caráter público, uma vez que, a priori, é uma paixão que tende aos valores de universo. Partindo, assim, desse pressuposto, interessa-nos obter a cifra tensiva dessa paixão, primeiro a partir de seu sentido dicionarizado e, em seguida, observar de que forma essa paixão tem seu sentido engendrado nos textos que analisamos.

Retomemos algumas definições a fim de cifrar tensivamente a comoção: "emoção forte e repentina" - implica tanto uma alta tonicidade ("forte") quanto um andamento acelerado ("repentina"). Tal celeridade se verifica também em "agitação, alvoroço".

Vejamos ainda outro trecho da definição: "revolta popular, levantamento, agitação social $<$ a comoção ganhou as ruas >". Pelo uso da metáfora geográfica, a comoção é portadora de grande extensidade graças à rapidez com que se alastra no espaço mental dos actantes/atores coletivos. Beividas e Ravanello (2006, p. 141) chamam esse fenômeno de "contágio psíquico", baseado na teoria freudiana sobre casos de histeria, que funciona como um mecanismo de identificação, isto é, "um /querer/ ou um /poder/ pôr-se na mesma situação" do outro. Dessa forma, tal contágio tímico amplo confere à compaixão, ainda que metaforicamente, um considerável grau de espacialidade.

Quanto à temporalidade, na primeira subseção analítica pudemos verificar que a combinação concessiva do "crer no inacreditável” foi um dos fatores responsáveis pela duração na mídia do Caso Isabella Nardoni. A 
comoção, assim, além de grande espacialidade, pode admitir uma grande temporalidade, a depender da manutenção da intensidade, a despeito da passagem do tempo.

Há, entretanto, matizes de intensidade de comoção, conforme sugere o dicionário: "provocar ou sentir enternecimento; fazer perder ou perder a dureza de alma" implica um grau menor de intensidade, ao passo que, “emoção forte e repentina" já sugere um grau de intensidade muito maior. A sintaxe extensiva da comoção dá-se por mistura: são os valores de universo a que essa paixão visa. Com efeito, se ela implica uma grande espacialidade, um actante coletivo, a comoção é regida pelos valores de universo. Após termos observado de que forma o sentido de comoção, como paixão coletiva, está estocado de forma potencializada, passemos a analisar de que maneira esse estado patêmico se realiza no/pelo corpus.

\subsubsection{Análise III}

Em 03/04/2008, vê-se a seguinte manchete: "Morte de Isabella comove o Brasil" (itálicos nossos). Segue um trecho da reportagem: "A comoção provocada pela morte de Isabella tomou o Brasil e se tornou um dos principais assuntos das conversas, tanto nas ruas quanto na internet" (itálicos nossos). Vale destacar que a comoção a que o noticiário se refere é nacional: "comove o Brasil; a comoção [...] tomou o Brasil”. Essa metáfora geográfica, conforme dissemos, significa dizer que o fato semiótico em questão se faz presente num campo de presença extenso. Isso se explica narrativamente pelo actante coletivo modalizado pela comoção e, discursivamente, por um ator coletivo também apaixonado: a população brasileira comovida. Assim, essa paixão, 
poucos dias após a morte da criança, já apresenta um alto grau de espacialidade, pois havia se disseminado por todo o País que, de acordo com o texto, condói-se com o assassinato.

Durante o off ${ }^{58}$ narrado pelo repórter, imagens de um vídeo, mostradas em quadros a seguir, são exibidas:

Isabella, a menina sorridente que aparece num vídeo divulgado nesta quinta na internet faria seis anos daqui a duas semanas. As fotos foram reunidas pelo namorado da mãe, Ana Carolina Oliveira, em uma homenagem à menina.
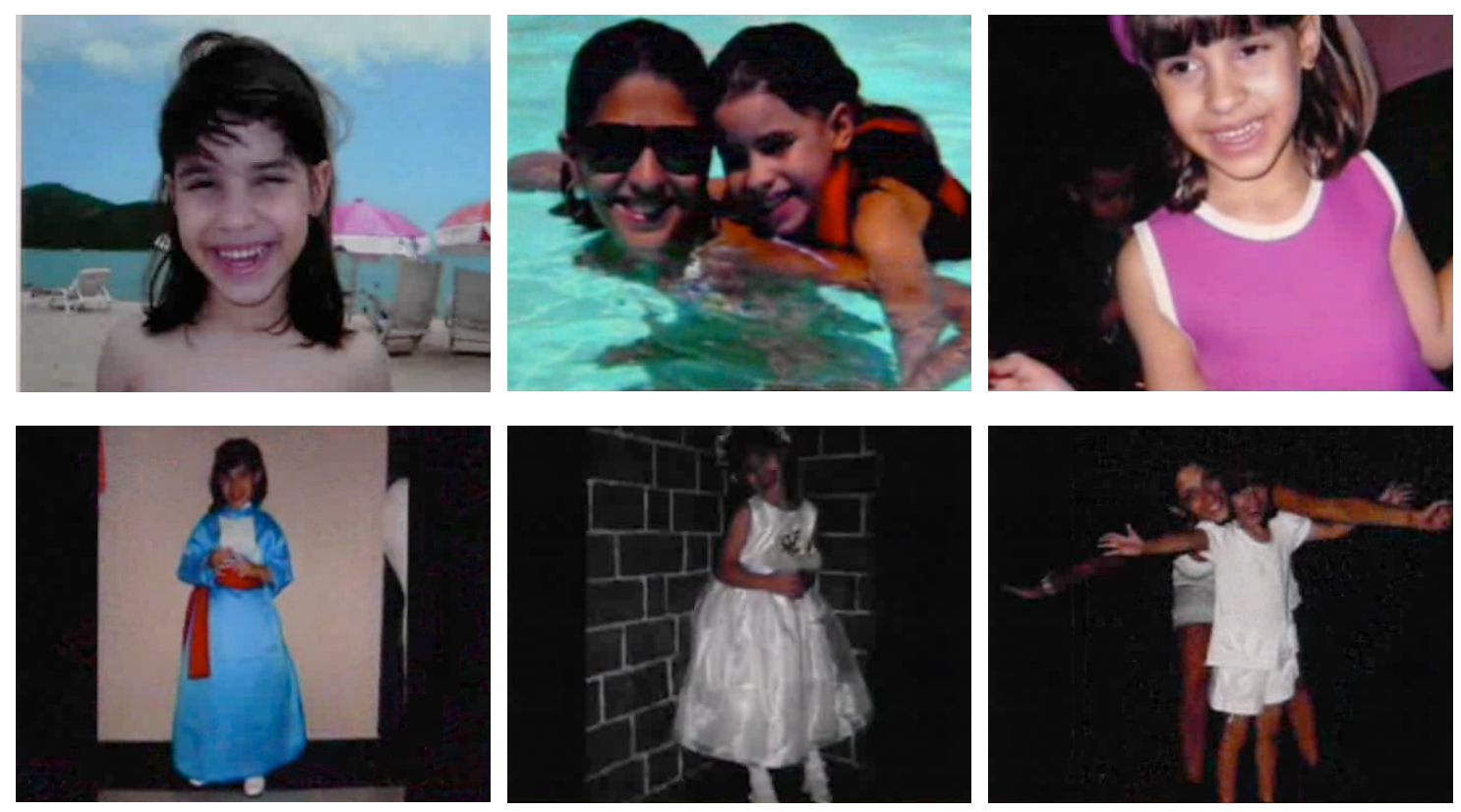

Estratégias como uso da figura "menina sorridente [que] faria seis anos daqui a duas semanas" brutalmente assassinada, combinadas com

\footnotetext{
58 "Texto lido pelo apresentador, locutor ou repórter e coberto com imagens" (BISTANE; BACELAR, 2010, p. 135).
} 
imagens das quais se depreendem traços sêmicos como /alegria/, /fragilidade/, /infância/, /inocência/ tonificam o campo de presença do sujeito semiótico (enunciatário). Graças a essa tonificação, o programa noticioso, além de se referir a uma comoção nacional, (re)cria-a discursivamente e, ao fazê-lo, incita no enunciatário a mesma paixão. Conforme dissemos, a reverberação do acontecimento, além da irrupção de novos microacontecimentos, cumpre a função de manter em elevado grau o eixo da intensidade. Noutros termos, tal estratégia corrobora a estratégia discursiva que vimos chamando de extensivização do intenso do caso em análise.

Ressalte-se mais uma vez que não se trata de uma menina de beleza tida como disfórica, mas de uma menina considerada bonita pela axiologia vigente. Frise-se ainda que a criança assassinada pertencia à classe média, o que singulariza o evento, fato que compele o enunciatário a se sensibilizar, a se comover com a morte da menina ${ }^{59}$.

Cria-se assim um estado emocional que se alastra rapidamente (andamento acelerado), com elevado quantum afetivo (forte tonicidade) e que se espalha pelo Brasil inteiro (alto grau de espacialidade). Via persistência, conforme foi visto na primeira subseção analítica, o fait divers em questão, assim como a comoção em torno dele, revelam-se duradouros (alto grau de temporalidade).

A mesma reportagem narra:

\footnotetext{
${ }^{59}$ Desnecessário dizer que se a vítima fosse negra e pobre, muito provavelmente, não haveria (tamanha) comoção, conforme será visto, a título de comparação, na reportagem de $O$ Globo, em que um bebê negro é espancado até a morte pelo pai e pela madrasta (item 3.3.1).
} 
Isabella estudava numa escola da Zona Norte de São Paulo havia pouco mais de um ano. Ela estava no pré. A mãe de um coleguinha que conhecia bem Isabella diz que todos estão chocados pela morte brutal. Ela conta qual é a imagem da menina que ficará na memória.

No quadro abaixo, vê-se a mãe de um colega da menina, cuja declaração é: "Ela era linda, sorridente" (itálicos nossos), declaração que corrobora a ideia de Isabella Nardoni ser uma criança bonita pelos padrões axiológicos vigentes na sociedade brasileira.

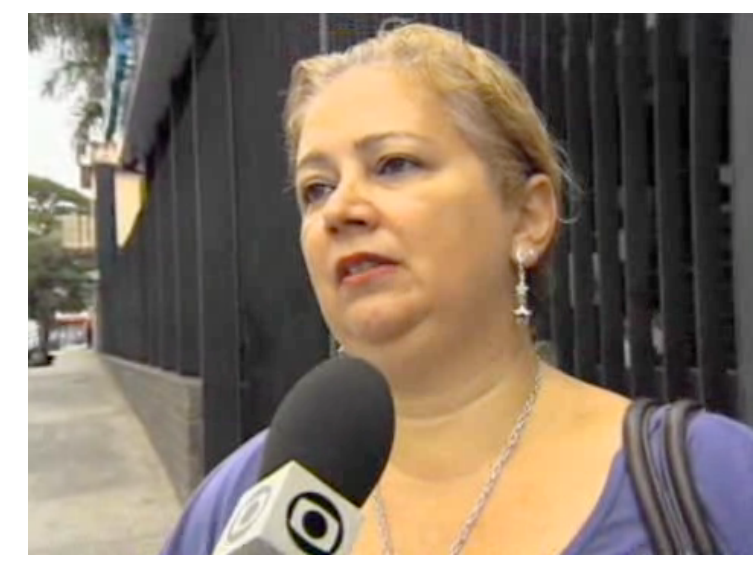

A estratégia de se valer da metonímia para dizer da comoção que abalara o Brasil foi diversas vezes utilizado pelo programa, tal como também no trecho a seguir:

O pequeno João Vítor conheceu Isabela. "A gente brincava em piscina de bolinha. Ela era uma boa amiga". A avó dele conta como o menino reagiu. "Ele falou: 'Vó, hoje a Isabella não vem, porque ela caiu pela janela, então ela só volta amanhã'. Isso é a consciência dele. Ele pensa assim”. 
O telejornal, assim, narra os estados emocionais de pessoas que conheceram Isabella para fazer-parecer verdadeira a comoção nacional que mencionou no começo da reportagem.

O repórter afirma ainda que: "A notícia da morte de Isabella deixou os funcionários da escola onde ela estudou em 2006 abalados. A diretoria está convidando os pais dos alunos para a missa de sétimo dia, que será nesta sexta”.

Dessa forma, o enunciador "Jornal Nacional", além de se referir à comoção do Brasil, (re)criando-a discursivamente, como dissemos, reforça essa "ebulição de afetos", impingindo ao enunciatário "telespectador" um fazer-sentir, um fazer-sofrer, um comover-se. Conforme já foi mencionado, esse fazer-persuasivo estésico pode surtir até mais efeito como estratégia manipulatória - a qual visa à fidelização/manutenção da audiência - do que um fazer-persuasivo apenas cognitivo.

A mesma reportagem de 03/04/2008 também diz: "Na página de relacionamento de Ana Carolina na internet, já foram escritas mais de 100 mil mensagens". A comoção que modaliza o actante coletivo aqui é expressa por números: 100 mil mensagens de pessoas que expressam seus sentimentos à mãe de Isabella.

No dia seguinte, em que foram levadas ao ar quatro reportagens sobre o Caso Isabella Nardoni, o título de uma delas foi: "Missa emocionante por Isabella”. Segue a cabeça: "A estimativa é que 800 pessoas, entre elas a mãe da menina, parentes e amigos, acompanharam a celebração numa igreja em São Paulo". Ainda segundo a repórter, "o momento mais emocionante da 
missa foi quando $[o]$ padre pediu que, em silêncio, todos rezassem pela garota".

No dia 05/04/2008, uma reportagem narra que:

Hoje seria um dia de comemoração: Ana Carolina Oliveira completa 24 anos. Mas, no lugar da festa, houve oração e muita demonstração de carinho. A mãe de Isabella foi logo cedo a um culto religioso no mesmo bairro onde mora, na zona norte de São Paulo. Na volta, encontrou um grupo de manifestantes com cartazes de solidariedade em frente a sua casa. Ela, então, recebeu o apoio de desconhecidos que até arriscaram um parabéns (itálicos nossos).

Nos quadros que se apresentam a seguir, veem-se, em sequência, no primeiro, desconhecidos de mãos dadas fazendo orações na porta da casa de Ana Carolina Oliveira. No quadro seguinte, manifestantes com cartazes de apoio; numa tomada aérea, pode-se notar a movimentação de muitas pessoas comuns e de jornalistas em frente à residência da mãe de Isabella. O último quadro mostra desconhecidos cantando parabéns para Ana Carolina Oliveira na data em que completava 24 anos. É digno de nota que os quadros apresentados, pela concentração de pessoas e em movimento, apresenta um andamento acelerado e, portanto, uma intensidade em grau elevado. 

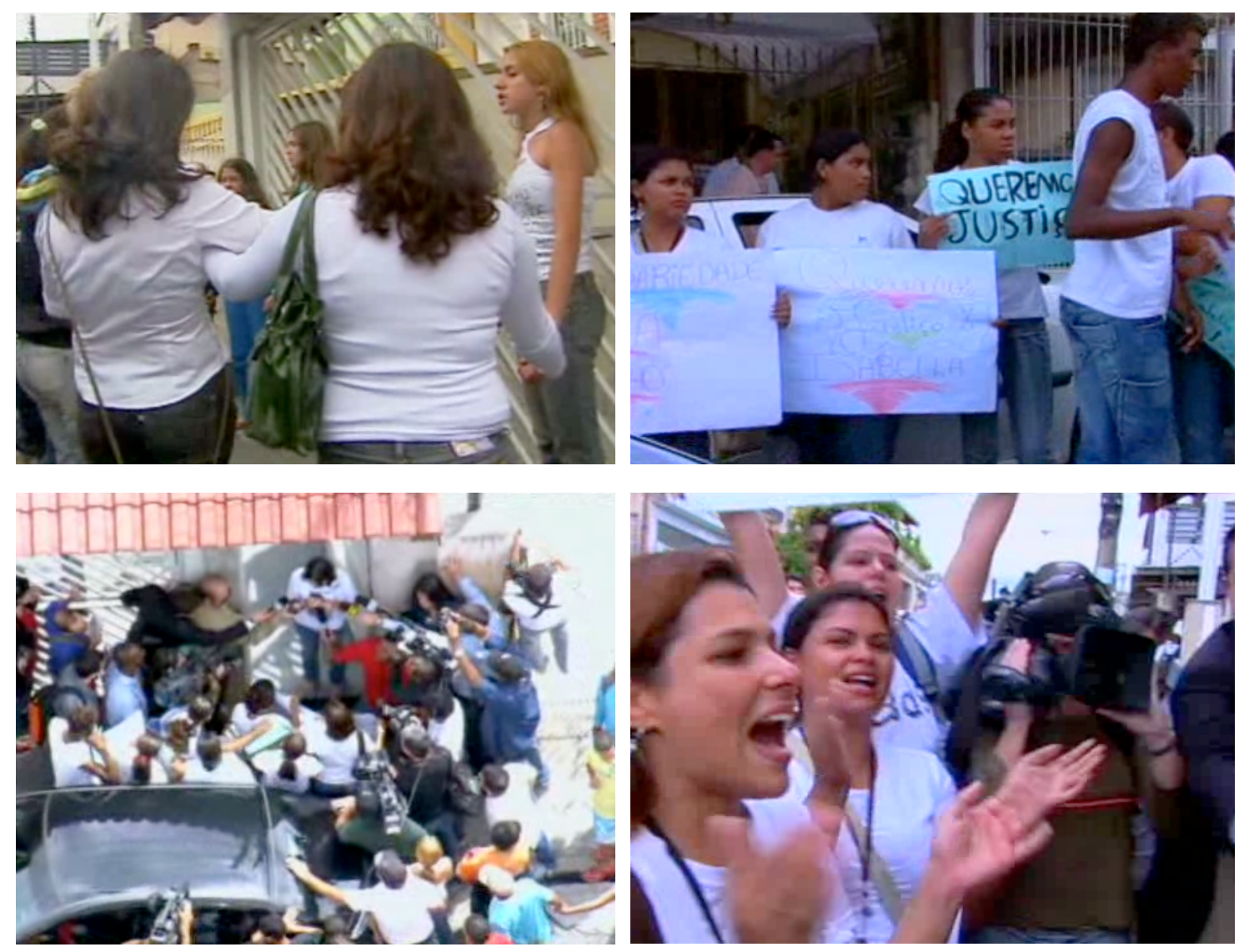

Na mesma edição daquela noite, outra reportagem aborda o tema da comoção social que havia se instalado no Brasil desde a morte de Isabella: "Foi um dia de muitos abraços na casa de Ana Carolina". O quadro a seguir mostra esse estado de comoção ao flagrar um momento em que uma desconhecida abraça a mãe de Isabella: 


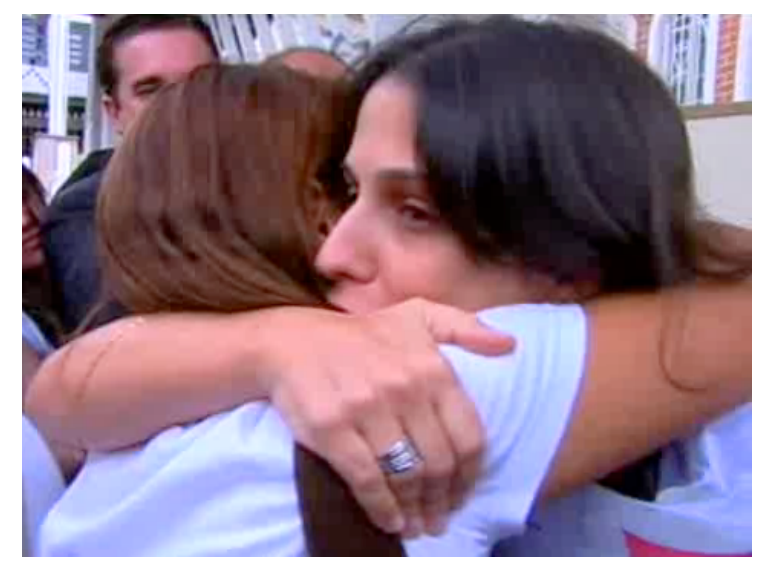

Segue a reportagem:

Entre tantas visitas, uma hora e meia de conversa com o comerciante Masataka Ota. Onze anos atrás, o filho dele, Yves, de 8 anos, foi seqüestrado [sic] e morto por bandidos, um crime difícil de perdoar. Mas o pai superou a revolta e criou uma ONG que prega a paz e o perdão. Uma filosofia que hoje, mais uma vez, ele dividiu com uma família de luto. "Eu tenho certeza de que Isabela no céu está olhando para a mãe e falando: 'Poxa, cumpri a missão e a mãe entendeu'. Entendeu a partida da filha e não tem nada de ódio, não tem nada de violência. A gente vê que ela está cheia de amor, perdão, ela não tem raiva de ninguém”, contou ele.

Os quadros abaixo mostram a chegada de Masataka Ota à casa de Ana Carolina Oliveira; a imagem do filho Yves, que também fora assassinado, a entrevista que o comerciante concede aos jornalistas presentes no local e o momento em que ele se despede da mãe de Isabella: 

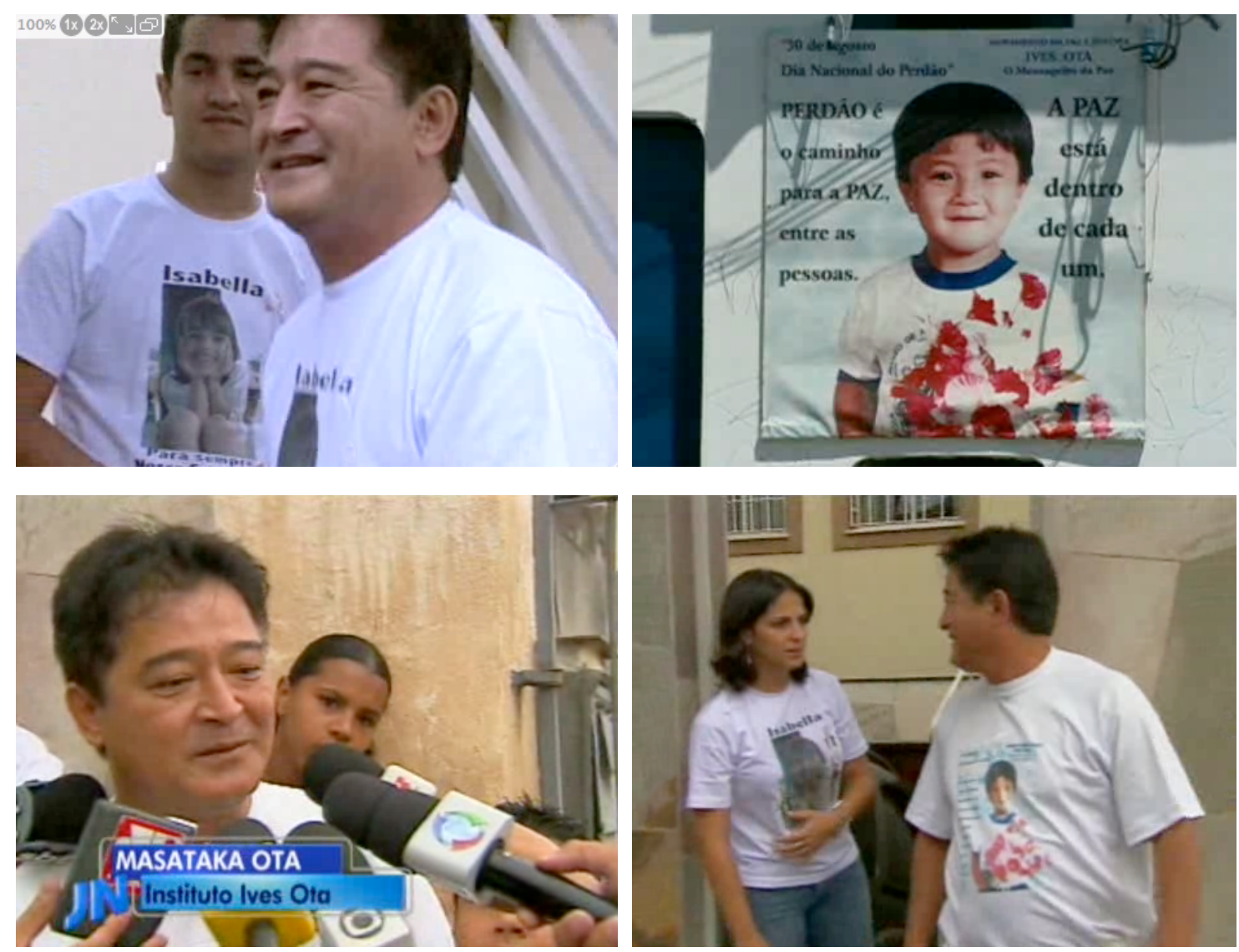

A presença de Masataka Ota, que faz menção à morte de seu filho, mostra-nos como o Caso Isabella Nardoni, apesar de ser de um tipo raro, é representativo de outros inúmeros casos que repercutiram na mídia e permanecem potencializados na memória coletiva. Dessa forma, é importante ressaltar que a mídia cumpre o papel de atualizar casos que estavam potencializados por meio daqueles cujo modo de presença é a realização.

Na mesma reportagem, o Jornal Nacional mostra outros casos semelhantes: 
É na solidariedade, no apoio a quem está sofrendo, que muitas famílias que perderam filhos encontram forças para recomeçar a vida e seguir em frente. Quando Marcelo morreu, aos 6 anos de idade, Lígia Abs André quase enlouqueceu. Heloísa Viana Porto também não acreditava que conseguiria sobreviver à morte de Fabio, de 5 anos. "Essa fase é muito difícil, metade de você vai embora", diz ela. Aos poucos, foram descobrindo que compartilhar a dor é o melhor remédio e criaram uma associação de apoio a outros pais.

Pelos trechos transcritos acima, o da missa de sétimo dia, o dos abraços na porta da casa de Ana Carolina Oliveira e o apoio que ela recebeu de pessoas que passaram por situações semelhantes, em que perderam seus filhos, ilustram o estado de comoção aludido pelo Jornal Nacional. Nos dois últimos trechos, fala-se em "solidariedade", para o Houaiss, "sentimento de simpatia, ternura ou piedade pelos pobres, pelos desprotegidos, pelos que sofrem, pelos injustiçados etc.; manifestação desse sentimento, com o intuito de confortar, consolar, oferecer ajuda etc.”. A solidariedade aproxima-se de uma das definições de comoção, apresentada no início da subseção anterior "provocar ou sentir enternecimento". Entretanto, em termos tensivos, a solidariedade é menos intensa que a comoção. No primeiro caso, o sujeito apenas sensibiliza-se com a dor do outro; no segundo, no caso da comoção, o sujeito sente-se literalmente no lugar do outro, partilhando da mesma dor, tal como mostrado no caso do abraço de uma desconhecida na mãe de Isabella e na visita feita por Masataka Ota, que também havia perdido o filho.

Cabe dizer que esse estado passional coletivo de comoção, em termos tensivos, remete ao estado de estupor do sujeito semiótico, que, diante de um evento que adentra abruptamente seu campo de presença, deixa-o sem voz. Trata-se de um estado coletivo, social, em que os ânimos estão ainda 
muito abalados. Visa-se, assim, a transformar em discurso o que é essencialmente da ordem do sentir.

Vejamos mais alguns trechos que demonstram esse estado de comoção pública: "Preces por Isabella. Moradores da Zona Norte, região onde ela morava, organizaram uma missa celebrada na noite desta terça para lembrar um mês da morte da menina." Segue a reportagem: “No cemitério, mais homenagens, flores e bonecas sobre o túmulo”.

Uma senhora, que tampouco chegou a conhecer Isabella ou sua família pessoalmente, afirmou: "Chorei muito esses dias, se não viesse aqui hoje não ia agüentar [sic]". Nota-se que tal depoimento corrobora a ideia de que a comoção é mais intensa que a solidariedade e pressupõe um efetivo colocar-se no lugar do outro. Abaixo, vê-se a imagem da senhora, visivelmente emocionada, que fez a declaração anterior:

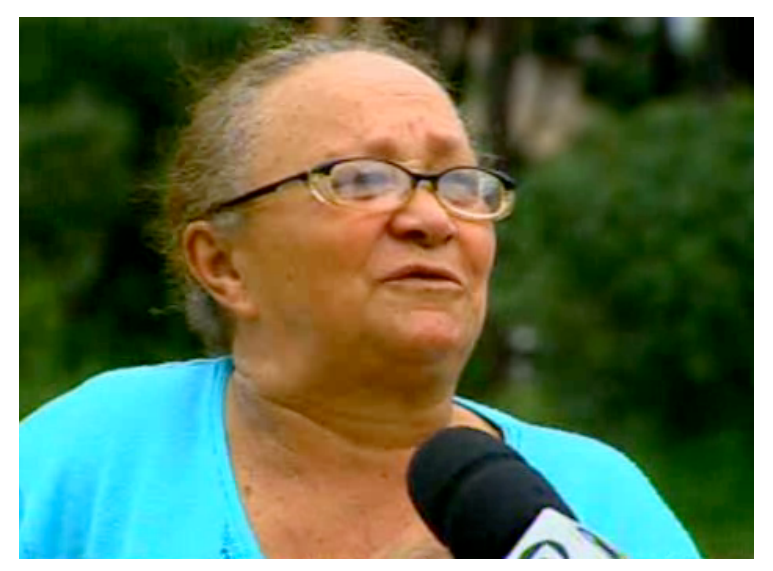

A reportagem ainda mostrou que:

Funcionárias do hospital onde Isabella foi socorrida depois de ser jogada do sexto andar do edifício London trouxeram velas e cartazes. "Acho que, de certa forma, a Isabella faz parte da nossa vida", disse uma mulher. 

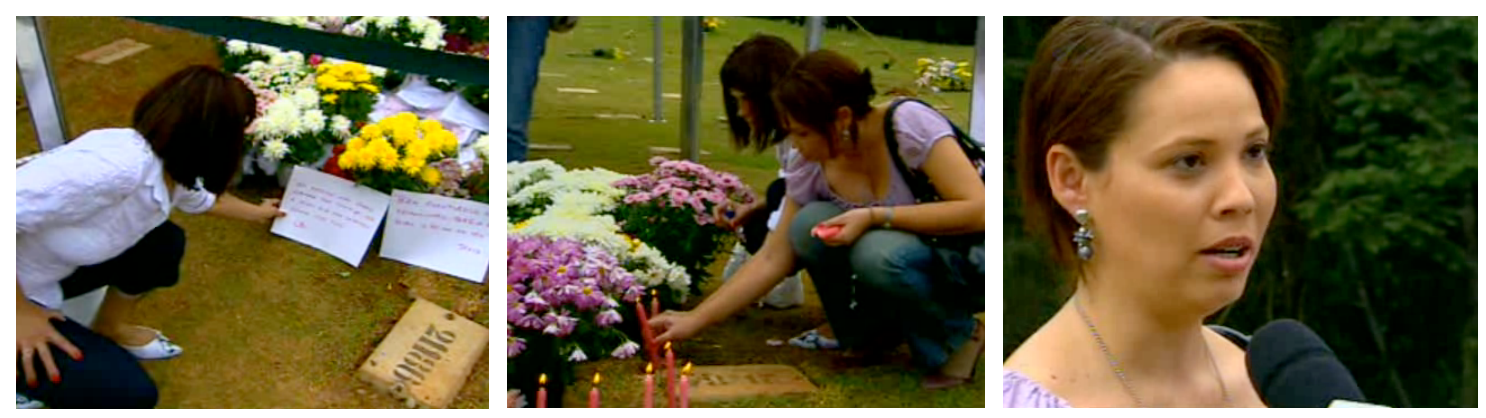

O Caso Isabella Nardoni, que se arrastou durante meses a fio na imprensa diária, configurando-se como um fato semiótico com alta carga de intensidade e de extensidade, criou em torno de si esse estado de comoção coletiva, cuja intensidade só poderia ser atenuada na e pela temporalidade, no transcurso do tempo. Assim, quanto maior a carga tímica de um evento midiático dessa natureza, maior é a sensação de clamor público, de comoção social.

Em 30/04/2008, um trecho da reportagem daquela edição narra:

Nesta quarta, um mês depois de atestada a morte da menina, a mãe de Isabella foi até o cemitério Parque dos Pinheiros e explicou por que tem se mantido em silêncio. "Gente, eu vou falar com vocês na hora certa, na hora que eu achar que é a minha hora, agora eu não estou conseguindo", disse Ana Carolina Oliveira. Para os parentes, também foi difícil expressar os sentimentos. "É uma angústia muito grande, um sofrimento por dentro, nem tem o que falar", disse o avô de Isabella. "O coração tá muito abalado”, confirmou a avó (itálicos nossos).

No excerto acima, percebe-se que, com frequência, os estados emocionais não se definem por meio de uma lexicalização específica nas declarações de parentes que sofreram a perda de Isabella. Poder-se-ia 
remeter, na esteira de Landowski (2004), à ideia de "paixões sem nome", as quais, a nosso ver, em termos figurais, correspondem a um alto grau de intensidade, embora esse autor não utilize termos da gramática tensiva.

Landowski (2004, p. 211), em texto que analisa a cobertura midiática acerca da morte da princesa Diana, fala de um estado de comoção social que poderia muito bem ser aplicado ao caso aqui em análise. Diz o autor:

O drama midiatizado, o espetáculo - todo esse "cinema" tornou-se nossa própria realidade: tanto um objeto de conversação rigorosamente inevitável (como pode ser o retorno obsessivo por uma presença perdida) quanto um estado de alma partilhado por todos.

No trecho que se apresenta a seguir, da reportagem também exibida em 30/04/2011, fala-se em homenagens à mãe de Isabella feitas por "quase 200 pessoas", além de carinho e saudade:

Quase 200 pessoas prestaram homenagens à menina. Também compartilharam a dor da família durante a missa. Ana Carolina Oliveira deixou no altar a camiseta que usava, com a foto de Isabella. Depois, emocionada, se aproximou do túmulo da filha. A mãe de Isabella deixou flores, uma boneca e uma mensagem de carinho e saudade (itálicos nossos).

Assim, mais uma vez, retomando as ideias de Zilberberg (2011a), no calor do acontecimento, cabe ao sujeito semiótico apenas um sofrer. Em 08/05/2008, uma expressão utilizada é reveladora desse estado de estupor coletivo: "o crime que chocou o país". Por tal razão, uma intensidade elevada no nível tensivo repercute, por exemplo, no nível da narrativa, por meio de sujeitos coletivos apaixonados. 
Assim, a intelecção do que é essencialmente sensível só se torna possível via temporalidade, que, no caso enfocado, foi duradoura. Ademais, como se viu, a carga tímica em torno do Caso Isabella Nardoni foi crescente até determinado ponto, atingindo a saturação para, depois de uma longa duração, começar a atenuar-se.

Pela sociossemiótica, caberiam ainda alguns acréscimos à nossa reflexão acerca da comoção, ou, simplesmente, de "um estar junto que se coloca a fazer sentido" (LANDOWSKI, 2004, p. 201-202). Para o autor, o sentir-junto cria um corpo que se reúne e se reconhece como uma unidade viva:

De forma inesperada, transforma-se por um tempo o que era apenas uma coleção de indivíduos dispersos, mais ou menos privados de um "laço social", como dizem os sociólogos, em um povo solidário, indiviso e, quase espantado, de, de repente, reconhecer-se como um todo - um nós orgânico e vivo. [...] O sentimento de um pertencimento comum, de um estar-com, diretamente, intimamente, "visceralmente", sentido [pelos membros dessa coletividade] evidencia o sentido de viver junto, além de uma simples promiscuidade entre grupos e indivíduos.

Para Landowski (2004, p. 202), esse sentimento capaz de fazer de indivíduos sem laços sociais um bloco único relaciona-se ao que o autor chama de contágio, um regime caracterizado pela seguinte descrição:

Corações batendo em uníssono, corpos diretamente colocados em contato pelo gesto ou pelo toque, ou como nesse caso, pelo choro, é, em primeiro lugar, sobre o plano da intersomaticidade (mais que a intersubjetividade) que esse "milagre" se realiza: o momento em que o social se faz corpo. 
A comoção a que nos referimos ou, simplesmente, "o sentimento coletivo de estar junto fundado sobre os poderes do sensível" (p. 211) representa, para Landowski, uma das condições necessárias para a constituição do social. O autor lembra que uma comunidade, para além de um pacto racionalmente articulado ou de uma associação de interesses, é uma comunidade de gostos e afetos.

Portanto, a presença da comoção, das paixões - nomeadas ou não ilustram, no Caso Isabella Nardoni, a constituição de sujeitos coletivos via estesia, via afeto, em suma, pelo sensível. Dessa forma, as oscilações entre intensidade e extensidade do nível tensivo ressoam nos níveis mais concretos do percurso gerativo do sentido, nesse caso, nomeadamente, por meio das paixões.

\subsubsection{Tensividade e relações intertextuais/ interdiscursivas}

O último eixo que conduz nossa análise visa a explicar a duração e, consequentemente, o interesse do enunciatário pelo Caso Isabella Nardoni, a partir de relações intertextuais e interdiscursivas. No primeiro caso, as relações estão textualizadas; no segundo, referem-se apenas ao plano de conteúdo dos textos.

Conforme já informamos, o viés da tensividade não prescinde da semiótica narrativa clássica - mas a complementa. Retomando a afirmação de Zilberberg (2011a, p. 16): “a 'casa do sentido' é vasta o bastante para acolher tanto o contínuo, quanto o descontínuo, mesmo porque nem este nem aquele fazem sentido por si mesmos, mas apenas por sua colaboração”. 
Assim, valemo-nos da afirmação de Greimas (1983, p. 50), segundo a qual, a narrativa aparece como o princípio organizador de qualquer discurso e, em última instância, do próprio imaginário humano: "A estrutura actancial aparece cada vez mais como apta a dar conta da organização do imaginário humano, projeção de universos coletivos tanto quanto individuais". Dessa forma, encontram-se cristalizadas na cultura algumas formas narrativas, as quais, por intertextualidade ou interdiscursividade, são acionadas no contato com "novos" textos. As aspas aqui se devem ao princípio de que "na intertextualidade não há fronteiras, não há linha divisória entre o eu e o outro, não há ruptura, [pois] a retomada da palavra do outro é constitutiva de qualquer discurso" (DISCINI, 2004, p. 11). Em outras palavras, segundo Lara e Mendes (2012, p. 116), "retomando uma figura já utilizada por Bakhtin, apenas o Adão mítico teria construído um discurso inédito, não perpassado por outros discursos”.

Dessa forma, o enunciatário "telespectador", ao entrar em contato com o Caso Isabella Nardoni, relaciona-o com outros textos e discursos que circulam socialmente, pois são concebidos no bojo da cultura, e que, por isso, fazem parte do "imaginário humano", para retomar a expressão utilizada por Greimas.

Nesta subseção analítica, valemo-nos dos conceitos de interdiscursividade e de intertextualidade. Por meio deste último, relacionamos o Caso Isabella Nardoni a dois contos maravilhosos (ou "contos de fadas", como em português é mais comum) recolhidos pelos irmãos Grimm (2012) da tradição oral alemã, que até hoje povoam nosso 
imaginário $^{60}$. Quanto ao conceito de interdiscursividade, cotejamos o Caso Isabella Nardoni com a estrutura do romance policial, ancorando-nos em Barthes (1964) e em Todorov (2006).

\subsubsection{Relações intertextuais}

Afirmam Lara e Matte (2009, p. 83) que "quando o assunto é intertextualidade - ou o 'diálogo' entre textos -, urge definir o que está dentro e o que está fora do texto. Mais que isso: urge delimitar 'o fora do texto' pertinente em uma análise semiótica da intertextualidade". Assim, a delimitação dos textos com os quais o texto em análise dialoga não é guiada senão pelos próprios elementos semânticos (como, por exemplo, os temas e as figuras) nele inscritos. No Caso Isabella Nardoni, o uso da figura "madrasta" baliza os textos de que fazemos uso para empreender essa relação intertextual, uma vez que as reportagens analisadas fazem uso recorrente do termo. Isso, evidentemente, não se faz sem que sentidos disfóricos sejam atribuídos ao ator do nível discursivo Anna Carolina Jatobá.

O lexema em questão encontra três definições no Houaiss. A primeira, nem eufórica nem disfórica e, portanto, neutra, é : “mulher em relação aos filhos anteriores do homem com quem passa a constituir sociedade conjugal"; a segunda e a terceira, por sua vez, são negativas: "mulher má, incapaz de sentimentos afetuosos e amigáveis; aquilo de que provêm vexames e dissabores em vez de proteção e carinho". Assim, a própria

\footnotetext{
${ }^{60} \mathrm{Em} 1812$ foram publicadas 86 narrativas, compiladas por Jacob e Wilhein Grimm, e, em 1882, os folcloristas alemães lançaram uma edição com 156 textos (Cf. MAZZARI, 2012, p. 11), de cuja recente tradução fazemos uso.
} 
definição de madrasta, com exceção da primeira, é carregada de sentidos disfóricos. Dessa forma, o motivo da crueldade da madrasta subjaz a sua própria figura, pois, é textualizado em diversas narrativas, nas quais a madrasta é sempre má.

Ainda no que tange ao uso de "madrasta" pela mídia brasileira na cobertura do Caso Isabella Nardoni, nossa afirmação é corroborada pela de Motta $(2008, \text { s/p })^{61}$, segundo a qual,

Na cordialidade brasileira, todo mundo é tio. É de "tia" que as crianças chamam a mulher do pai quando esta não é a sua mãe. A menos que a chamem simplesmente pelo nome, "fulana" ou "cicrana". Por outro lado, é "a companheira", ou a "segunda mulher", ou a "nova mulher", ou ainda a "nova esposa" de fulano que dizemos para nomear a mulher com quem alguém se recasou ou se juntou. Saído do domínio das bruxas, essas representantes da mãe má, desde a noite dos tempos, que é o tempo das histórias de fada, a palavra "madrasta" é no mínimo estranha como referência à segunda mulher do pai de Isabella Nardoni, Anna Carolina Jatobá. Primeiro, porque a madrasta é aquela que, na falta da mãe, está na função dela. [...] Isso torna, aliás, surpreendente a maneira como, até mesmo na Rede Globo [...] prosperou "a madrasta", em lugar de "a mulher" de Alexandre Nardoni, trocando-se, assim, também no registro do padrão de qualidade, uma formulação em bom português por outra pomposa, falseada e punitiva. [...] É que 'madrasta' já é um veredicto, uma condenação prévia, daí sua utilidade" (itálicos nossos).

Por isso, afirma Fiorin (2006, p. 106) que o lugar privilegiado de manifestação da ideologia é o nível dos temas e figuras. No seu entender, "não é nos níveis mais abstratos do percurso gerativo que se manifesta, com plenitude e nitidez, a ideologia, mas na concretização dos valores semânticos"

\footnotetext{
${ }^{61}$ Edição online, sem numeração de páginas.
} 
(itálicos nossos). Assim, a figura madrasta já carrega consigo uma sanção negativa, um valor disfórico, além de permitir a intertextualidade com contos de fada conforme se apresenta a seguir.

\subsection{Análise IVa}

Nesta subseção analítica apresentamos trechos de dois contos dos irmãos Grimm (2012), em que a figura da madrasta concretiza os valores disfóricos já mencionados pelo Houaiss e que fazem parte de nossa cultura, para, depois, cotejá-los com trechos das reportagens sobre o Caso Isabella Nardoni, levadas ao ar pelo Jornal Nacional.

O primeiro conto de que nos valemos é "A Gata Borralheira”. Segue um trecho:

Era uma vez um homem rico que viveu feliz com sua mulher por muito tempo e juntos tiveram uma única filha. Um dia a mulher adoeceu [...] e morreu. [...]. Seu pai se casou novamente. Mas a madrasta já tinha duas filhas de seu primeiro marido, bonitas de aparência, mas orgulhosas, pretensiosas e más de coração. Depois do casamento, as três foram morar na mesma casa e a vida se tornou dura para a pobre criança. "O que esta menina inútil e desagradável está fazendo aqui? Vá para a cozinha que lá é seu lugar!", disse a madrasta, e acrescentou: "Ela será nossa criada e terá de ganhar o pão com seu trabalho diário. Então, suas irmãs postiças the tiraram os lindos vestidos $[\ldots]$ E, assim, debochando, mandaram-na para a cozinha. E, a partir desse dia, a menina passou a trabalhar arduamente. [...] ̀̀ noite, extenuada, não tinha uma cama para descansar. Deitava-se perto da chaminé, junto às cinzas do borralho. E, como estava sempre suja por ficar dormindo nas cinzas e na poeira, deram a ela o nome de Gata Borralheira" (GRIMM; GRIMM, 2012, p. 116-117). 
O segundo conto, com o qual se pode estabelecer intertextualidade com o Caso Isabella Nardoni, é "O pé de zimbro", do qual se extraiu o seguinte excerto:

Muito tempo atrás, há cerca de dois mil anos, vivia um homem rico cuja mulher era bela e devota e o casal se amava muito, mas não tinha filhos. Como queriam muito tê-los, a mulher rezava noite e dia para ganhá-los, mas por mais que quisessem, eles não vinham. Em frente à casa, havia um jardim em que crescia um pé de zimbro. Num dia de inverno, a mulher estava debaixo da árvore descascando uma maçã e, ao descascá-la, cortou o dedo e o sangue pingou na neve [...]: "Como eu queria ter um bebê vermelho como o sangue e branco como a neve". Assim que disse isso, ela sentiu uma alegria em seu coração, como se fosse acontecer alguma coisa $[. .$.$] . Quando nasceu um bebê branco como a neve e$ corado como o sangue, [...] ao vê-lo, ela ficou tão feliz que morreu. O marido a enterrou debaixo do pé de zimbro e chorou muito. Assim foi por um tempo, até que as lágrimas começaram a atenuar-se [e] ele casou-se novamente. Ele teve uma filha com a segunda mulher [...]. Quando a mulher olhava para a própria filha, sentia afeto; já quando olhava para o menino, sentia um aperto no coração, como se ele sempre fosse ficar em seu caminho $[. .$.$] até que o ódio tomou$ conta dela e ela começou a tratar o menino muito mal. [...] $\mathrm{O}$ menino surgiu à porta e o Diabo a fez ser simpática com ele e ela disse fitando-o com os olhos raivosos: "Meu filho, quer uma maçã?" [...] e abriu a pesada tampa do baú. "Pegue uma maçã aqui de dentro!". Quando o pequeno se curvou sobre o baú, o Diabo a aconselhou e pum! Ela bateu a tampa, decepando a cabeça do menino, que rolou entre as maçãs (GRIMM; GRIMM, 2012, p. 220-222).

Pelo que se pode observar, em ambos os contos, a madrasta é um sujeito malevolente, que, de alguma forma, quer se livrar do(a) enteado(a). No primeiro caso, faz de criada a filha fruto do primeiro casamento do marido; no segundo, mata, decapitando o enteado. Em ambos os casos, os filhos da primeira união do marido são, pelo ponto de vista da madrasta 
(sujeito do fazer), antiobjetos com os quais ela quer entrar em disjunção. E assim o faz.

No Caso Isabella Nardoni, não foi diferente. Segundo narrou o Jornal Nacional, em 01/05/2008,

Uma vizinha da família Nardoni disse à polícia que Anna Carolina [Jatobá] disputava a atenção do marido. Chegava a tirar Isabella do colo do pai para ela própria, Anna Carolina, sentar-se no colo dele, mesmo com a menina chorando.

No trecho acima, Isabella é, assim como nos contos de fada cujos excertos foram apresentados, um antiobjeto, pela perspectiva do sujeito do fazer, actorializado por Anna Carolina Jatobá.

Em 06/05/2008, o noticiário relata a versão do promotor que acompanhava o caso:

Francisco Cembranelli não fala em motivação, mas sim nas circunstâncias em que o crime ocorreu. "Houve uma discussão relacionada a ciúmes. No meio da discussão, a menina foi ferida. Imediatamente, outras agressões foram praticadas, culminando com o lançamento pela janela", afirmou.

Pelo fragmento transcrito, a madrasta, como nos contos reproduzidos dos irmãos Grimm, é um sujeito malevolente movido pelo ciúme que $f a z$ fazer e faz (pois é Destinatário do sujeito do fazer "pai" e também sujeito do fazer) para entrar em disjunção com o antiobjeto "Isabella" ${ }^{62}$.

\footnotetext{
${ }^{62}$ Segundo mostram Greimas e Fontanille (1993, p. 171), a paixão do ciúme se caracteriza como "uma relação intersubjetiva complexa e variável [...]: o temor de perder o objeto só se compreende aqui em presença de um rival ao menos potencial ou imaginário, e o temor do rival nasce da presença do objeto de valor que funciona como pivô".
} 
Pelo que se observa nos trechos de reportagens do Jornal Nacional, a figura da madrasta má, cristalizada pelos contos de fada, é acionada pelo ator do nível discursivo “Anna Carolina Jatobá”. Essa relação intertextual, ainda que de forma inconsciente, estabelece-se entre o caso enfocado com estereótipos arraigados da cultura popular, aqui representados pelos contos maravilhosos dos irmãos Grimm ${ }^{63}$.

Vale dizer também que, embora Fiorin (2006, p. 106) mostre que, numa análise, o importante sejam os percursos temáticos e figurativos, e não os temas e as figuras isolados, o uso abundante da figura "madrasta", ao qual subjaz o motivo da crueldade desta, pelo Jornal Nacional, tem uma função impregnante (TATIT, 2010), capaz de, via intertextualidade e/ou interdiscursividade, impingir à Anna Carolina Jatobá um papel temático carregado de valores disfóricos, emitindo, assim, uma sanção negativa à então suspeita.

Para corroborar nossa hipótese, valemo-nos do uso que o noticiário faz, ao longo das reportagens que compõem o corpus, do termo "madrasta" em relação ao antropônimo "Ana Carolina Jatobá”, ou variações como “Anna Jatobá". Conforme se pode ver na tabela abaixo, o termo madrasta foi o segundo mais utilizado pelo o Jornal Nacional para se referir a Anna Carolina Jatobá:

\footnotetext{
${ }^{63}$ Por isso, pode-se também pensar, em sentido lato, em relações interdiscursivas no que se refere à imagem de uma madrasta má, que encontra seu lugar privilegiado nos contos de fada, mas que também repousa no imaginário coletivo.
} 


\begin{tabular}{|c|c|}
\hline REFERÊNCIA & NÚMERO DE OCORRÊNCIAS \\
\hline An(n)a Carolina Jatobá & 58 \\
\hline Madrasta & 38 \\
\hline An(n)a Carolina & 34 \\
\hline An(n)a Jatobá & 10 \\
\hline A mulher & 9 \\
\hline Ela & 5 \\
\hline A mulher dele & 1 \\
\hline A mulher do segundo casamento & 1 \\
\hline A esposa & \\
\hline
\end{tabular}

Se, no entanto, forem consideradas apenas três categorias, a saber (1) variações do antropônimo; (2) "madrasta"; e (3) outros ("a mulher"; "ela"; "a mulher dele"; "a mulher do segundo casamento"; "a esposa"), podemos observar que, ainda assim, o segundo termo mais recorrente é "madrasta", conforme mostra a tabela a seguir:

\begin{tabular}{|c|c|}
\hline REFERÊNCIA & NÚMERO DE OCORRÊNCIAS \\
\hline Variações do antropônimo & 170 \\
\hline Madrasta & 57 \\
\hline Outros & 26 \\
\hline
\end{tabular}

Conforme salientou Motta (2008), o noticiário, que poderia fazer uso de "companheira", "segunda mulher", "nova mulher", "nova esposa", termos 
sem conotação negativa, preferiu fazer uso de "madrasta", já creditando à suspeita um veredicto ancorado num estereótipo da língua/cultura.

Assim, por meio da figura "madrasta", relacionam-se textos, de modo a fazer repousar o Caso Isabella Nardoni sobre outras narrativas que constituem o imaginário humano.

Portanto, a dramatis personae, para fazer uso mais uma vez da expressão barthesiana, que se encarrega de dar vida a um estereótipo, familiariza, de certa forma, o enunciatário com a história da morte da menina Isabella. Desse modo, a ideia de uma sanção negativa a que invariavelmente as madrastas dos contos de fada são submetidas, por serem sujeitos malevolentes, passa a sobredeterminar a expectativa do enunciatário, razão também pela qual o Caso Isabella Nardoni dura no eixo da extensidade, mantendo-se em alto nível também a intensidade. Desse modo, a relação entre expectativa e interesse tônicos do enunciatário com elementos da narrativa evidenciam como o contínuo liga-se estreitamente com o discreto.

\subsubsection{Relações interdiscursivas}

O conceito de interdiscursividade pauta a última subseção analítica do Caso Isabella Nardoni. Conforme dissemos, é possível estabelecer tal relação através da estrutura do romance policial. Barthes (1964, p. 198), no referido texto sobre a estrutura do fait divers, sinaliza essa analogia:

Quanto ao crime misterioso, conhece-se sua fortuna no romance popular; sua relação fundamental é constituída por uma causalidade diferida: o trabalho policial consiste em preencher de trás para frente o tempo fascinante e insuportável que separa o acontecimento de sua causa; o 
policial, emanação da sociedade inteira sob a forma burocrática, torna-se então a figura moderna do decifrador de enigmas.

Todorov (2006, p. 94), ao propor uma tipologia do romance policial, destaca: "o romance policial clássico $[. .$.$] conheceu sua hora de glória entre$ as duas guerras, e que podemos chamar 'romance de enigma"” (itálicos nossos). Segundo o autor, esse tipo de romance policial possui, invariavelmente, duas histórias: "Na base do romance de enigma encontramos uma dualidade $[\ldots]$ : a história do crime e a história do inquérito" (p. 95).

Assim, o policial ou o detetive, por meio de indícios, busca recriar as circunstâncias e as causas que motivaram um crime: "As cento e cinquenta páginas que separam a descoberta do crime da revelação do culpado são consagradas a um lento aprendizado: examina-se indício após indício, pista após pista". Todorov lista outros tipos de romance policial, tal como o romance negro, por exemplo. Interessa-nos, no entanto, a relação entre o romance policial clássico - ou "de enigma", conforme denomina o autor - , com o Caso Isabella Nardoni pelas similitudes entre ambos.

\subsection{Análise IVb}

O Caso Isabella Nardoni, tal como o romance de enigma, possui duas histórias. A primeira - a do assassinato - e a segunda, que se refere ao inquérito. A busca das razões que motivaram o crime, da identidade dos assassinos e das circunstâncias da morte da criança fizeram da cobertura midiática desse fait divers uma espécie de romance policial televisionado. Dia após dia, indício após indício, declaração após declaração, a história do 
inquérito ia (re)construindo a história do crime. Por essa perspectiva, podese estabelecer uma relação interdiscursiva entre o romance policial e o Caso Isabella Nardoni.

Modaliza-se, assim, o enunciatário, tal como no romance de enigma, por um querer-saber intenso, obstinado, que se tonifica a cada edição do noticiário $^{64}$. Vê-se que as modalidades e modalizações, pertencentes ao nível narrativo, também são passíveis de serem tomadas a partir de um ponto de vista tensivo, em que um querer-saber pode ser mais ou menos intenso, o que explicaria, via tensividade, o "excedente modal" a que se referem, várias vezes, os autores de Semiótica das paixões.

Os trechos das reportagens sobre o Caso Isabella Nardoni, televisionadas pelo Jornal Nacional, que se apresentam a seguir, visam a demonstrar as relações entre o caso e o referido gênero romanesco. Como estamos falando em romance policial em sentido genérico e não tratando de um romance policial específico, nesta situação, a noção de relação interdiscursiva é mais apropriada que a de intertextualidade, porquanto a textualização dá-se apenas no caso sob análise, e não a partir da relação entre dois ou mais textos.

Em 09/04/2008, o Jornal Nacional leva ao ar a seguinte reportagem, da qual se lê este excerto:

Desde a morte de Isabella, 11 dias atrás, 37 pessoas prestaram depoimento. Outras 19 devem ser ouvidas esta semana. "Não tem um depoimento que se destaca em relação aos demais,

\footnotetext{
${ }^{64}$ Para Greimas e Fontanille (1993, p. 63), a obstinação se define como a disposição de um sujeito "em estado de continuar a fazer [...] apesar de X". Ainda segundo Tomasi (2011, p. 31), o obstinado é "aquele que quer ser continuamente". A propósito dessa paixão, conferir também em Tomasi (2012).
} 
mas sempre eles estão se complementando, sempre um dando credibilidade ao outro, sempre um corroborando o outro", declarou a delegada Renata Helena Pontes. A delegada que comanda as investigações disse que já está perto de montar toda a cena do crime. "A gente já tem $70 \%$ referente à dinâmica, ao ferimento, aonde que aconteceu, enfim, tudo o que foi feito lá dentro até o final, até o óbito. Não sei se vai ser possível chegar a $100 \%$, mas a gente quer chegar o mais próximo da realidade".

Em 10/04/2008, o noticiário afirma: “A polícia espera esclarecer dados ainda obscuros na investigação com a quebra do sigilo telefônico de parentes de Isabella.” Em 11/04/2008, por sua vez, noticia-se:

Ainda há várias perguntas não esclarecidas: a que horas o casal chegou? Quanto tempo se passou entre a chegada e a queda de Isabella? De quem é o sangue encontrado no apartamento? Qual foi a causa da morte da menina? Asfixia, queda ou a combinação dos dois? "Não posso falar mais nada", disse a delegada.

O programa jornalístico do dia seguinte dá sequência ao enigma: "A gente tem que aguardar os laudos, reinquirição, reconstituição e aí o caso vai estar finalizado', disse a delegada Renata Pontes”. Dessa forma, edição após edição do Jornal Nacional, vai se intensificando um querer-saber capaz de manter intacta a intensidade do fato semiótico em questão, ou, ainda, é capaz de, por meio do recrudescimento, tornar o intenso ainda mais intenso, até chegar à saturação, conforme já demonstramos anteriormente. O enunciatário "telespectador" só consegue atenuar a intensidade desse querersaber quando Alexandre Nardoni e Anna Carolina Jatobá passam à condição de acusados pela polícia, conforme mostra a edição de 19/04/2008: 
Houve diferenças nas versões de Alexandre e Anna Carolina, tanto na comparação dos dois depoimentos de ontem e hoje de madrugada, quanto com relação ao primeiro relato que fizeram à polícia. Alexandre e Anna Carolina responderam às mesmas perguntas. O questionário de 50 itens fez o pai falar durante oito horas. O homem chorou várias vezes ao ver o álbum de fotos da filha. A madrasta de Isabella foi interrogada por cinco horas, principalmente sobre o que aconteceu depois do crime. Anna Carolina, que saiu de casa chorando, não se emocionou em nenhum momento na delegacia. Antes de assinar, os dois gastaram quatro horas conferindo o que haviam dito aos policiais. No final, foram formalmente acusados de homicídio doloso e triplamente qualificado, ou seja, segundo a polícia paulista, o casal matou a garota com intenção, por motivo infame e brutal, usando crueldade e sem dar chance de defesa à vítima (itálicos nossos).

Entretanto, o campo de presença do sujeito semiótico "telespectador" era novamente tonificado a cada novo detalhe que surgia em edições seguintes, ao qual demos o nome de microacontecimento. Exemplo disso é a edição do noticiário de 21/04/2008, que afirma:

Há indícios que reforçam a convicção de que Isabella foi asfixiada na sala: a quantidade de sangue encontrada perto do sofá demonstra que a menina ficou parada ali e o rastro de gotas de sangue, mais intenso na entrada, diminui no caminho para o quarto, o que indica que a menina já estava desmaiada quando foi levada na direção da janela. Outras conclusões dos legistas: a coagulação do sangue no ferimento que Isabella tinha na testa demonstra que ela foi machucada pelo menos dez minutos antes de ser jogada. Essa informação coincide com o laudo da perícia, que encontrou sangue de Isabella no carro da família, o que indica que a menina foi ferida antes de subir para o apartamento.

Em 01/05/2008 o enigma do caso começa a ser finalmente desvendado: 
O relatório mostra a versão da polícia para o crime e, segundo a delegada, levou em conta laudo do Instituto de Criminalística, lesões observadas na vítima e depoimentos de testemunhas. A primeira conclusão é que as agressões começaram no carro da família. Segundo o relatório, Anna Carolina Jatobá feriu Isabella na testa, com um instrumento não identificado. A madrasta segurava esse instrumento com a mão esquerda, virou-se para trás e alcançou o rosto da menina. A delegada diz que houve sangramento, gotejando sangue no assoalho, atrás do banco do motorista, na lateral esquerda do carrinho do bebê e um esfregaço, uma espécie de borrão de sangue na parte posterior do banco do motorista. [...] O relatório final sobre o caso menciona o fato de duas pessoas terem ouvido gritos de criança chamando o pai, pouco antes da queda de Isabella. A delegada Renata Pontes afirma: por causa das lesões, Isabella não podia gritar. Portanto, a voz era de do irmão de Isabella, de três anos, que queria que o pai intercedesse no momento em que a menina estava sendo asfixiada. E completa: sendo assim, se deduz que a pessoa que apertou fortemente o pescoço da vítima foi Anna Carolina Jatobá. A delegada Renata Pontes não indica o motivo do crime, mas afirma, no relatório, que há provas robustas de que Alexandre Nardoni jogou Isabella pela janela. As principais são as marcas da rede na camiseta de Alexandre e as marcas do chinelo que ele usava que ficaram num lençol.

Em 02/05/2008, o Jornal Nacional completa: “A conclusão: a morte foi de causa violenta, por asfixia mecânica e politraumatismo causado pela queda". Em 06/05/2008 o noticiário mostra que "o promotor Francisco Cembranelli [que acompanhava o caso] foi categórico: Alexandre Nardoni e Anna Carolina Jatobá mataram Isabella”.

Assim, conforme apontamos, o Caso Isabella Nardoni pode ser relacionado interdiscursivamente com o romance policial, especificamente, o romance de enigma, pela tipologia de Todorov (2006). O não-saber em torno dos assassinos, da motivação e das circunstâncias da morte de Isabella Nardoni configuram a mesma estrutura desse tipo de romance, razão pela 
qual cria-se um querer-saber cada vez mais intenso, que é somente atenuado com o desvendar do crime.

Cabe dizer ainda que esta última subseção analítica, que tratou de relações intertextuais, por meio do elemento "madrasta", e relações interdiscursivas constituem alguns dos procedimentos metodológicos de que a semiótica se vale para analisar o "exterior" ao texto, ou, segundo a expressão de Barros (2009), a "exterioridade discursiva", a partir de uma perspectiva semiótica. Por meio da análise de temas e figuras, revelam-se “de alguma forma, as determinações histórico-sociais inconscientes" (p. 352); pelas relações interdiscursivas e intertextuais evidenciam-se os liames que o texto sob análise estabelece com outros textos/discursos, chegando-se, assim, por uma via semiótica, à "exterioridade discursiva", sem abandonar, entretanto, as bases imanentes da disciplina.

Conforme também se pôde notar, relações intertextuais e interdiscursivas podem ser tomadas pelo viés da tensividade, uma vez que, por meio delas, no caso enfocado, aciona-se no enunciatário uma expectativa, um querer-saber ora mais ora menos intenso.

\subsection{LEITURA SEMIÓTICA DE OUTROS FAITS DIVERS}

Esta última seção analítica se presta a analisar outros faits divers. Se o Caso Isabella Nardoni é tomado, no escopo desta pesquisa, a partir dessa categoria englobante, é mister que outros textos pertencentes a ela sejam também observados, com o intuito de se estabelecer uma abordagem tensiva para essa categoria de relato noticioso, conforme já dito. 
Assim, nesta seção, detemo-nos em uma reportagem publicada pelo jornal $O$ Globo, cuja temática é a mesma do Caso Isabella Nardoni, diferenciando-se, entretanto, pela curta duração; examinamos uma reportagem exibida pelo Jornal Nacional a respeito do salvamento de queda acidental de uma menina autista de um prédio em Nova Iorque (EUA) e, finalmente, observamos alguns elementos constitutivos de outros faits divers, cujas coberturas, assim como o Caso Isabella Nardoni, tiveram grande repercussão.

\subsubsection{Reportagem de $O$ Globo}

Publicada em 19/07/2012 pelo periódico O Globo, a manchete do texto é "Bebê espancado até a morte, e casal é preso". O subtítulo, por sua vez, informa: "Pai diz à polícia que batia 'de forma educativa' no menino de dois anos; segundo vizinhos a madrasta também o agredia”. Logo abaixo do subtítulo, a imagem dos agressores e da criança, entubada e com "hematomas por todo o corpo", segundo afirma o texto da reportagem:

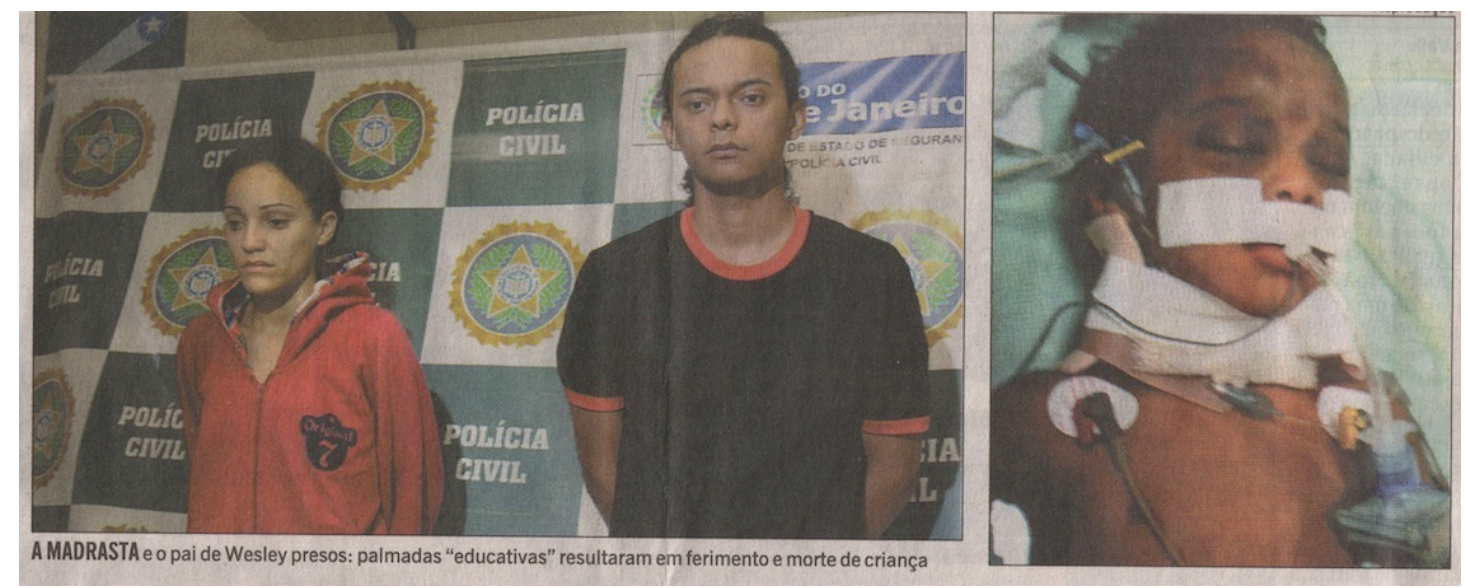


Na legenda da foto, em caixa alta, " A MADRASTA", enfatizando o parentesco disfórico entre a mulher e a criança, seguido por: "e o pai de Wesley presos: palmadas 'educativas' resultaram em ferimento e morte de criança”. O lide ${ }^{65}$ da reportagem informa:

Com hematomas por todo o corpo, fraturas no crânio e numa das pernas, um menino de 2 anos deu entrada anteontem à tarde no Hospital Cardoso Fontes, em Jacarepaguá, com parada cardiorrespiratória, em estado gravíssimo. A médica que atendeu Wesley Fernandes de Araújo - que morreu pouco depois de ser internado - desconfiou que as lesões do menino tinham sido provocadas por espancamento, e não por ter caído da cama, como contara a madrasta da criança. A polícia foi chamada e prendeu em flagrante, pelo crime de tortura seguida de morte, o pai e a madrasta, ambos de 23 anos. Se condenado, o casal que vive junto há dois anos, pode pegar até 21 anos de prisão.

O intertítulo, por sua vez, noticia: "Criança teria sido agredida por mexer no gás". Segue o texto:

Na delegacia, o pai, Windenberg de Araújo Souza, e a madrasta, Luana do Nascimento, travaram uma guerra de versões para tentar justificar os maus-tratos. Em depoimento, ela alegou inicialmente a versão contada no hospital, de que os ferimentos teriam sido provocados pela queda da cama. Mas, depois mudou sua versão e acusou o companheiro. Vizinhos disseram que Luana costumava agredir o enteado. Morador de Rio das Pedras, o pedreiro Windenberg disse à polícia que costumava bater no filho "de forma educativa". Na segunda-feira, véspera de o menino ser internado, ele teria agredido a criança porque ela tinha mexido no gás da cozinha

\footnotetext{
${ }^{65}$ Palavra aportuguesada do inglês lead. O jornalismo usa o termo para resumir a função do primeiro parágrafo, que é introduzir as principais informações do texto. Em geral, responde às questões principais em torno de um fato (o quê, quem, quando, como, onde, por quê). (Cf. Manual de Redação da Folha de S. Paulo). Disponível em: www1.folha.uol. com.br/folha/circulo/manual_redacao.htm. Acesso em: 22 abr. 2013.
} 
[...]. Ontem a polícia ouviu sete vizinhos do casal. Eles disseram que costumavam ouvir barulho de choro na casa. [...] De acordo com relatos, o som de choro e de pancadas dentro de casa pioraram nas últimas três semanas.

Nesse fait divers, com a mesma temática do Caso Isabella Nardoni, pai e madrasta são acusados de agredir até a morte a criança Wesley Fernandes de Araújo. O caso ressoou em $O$ Globo apenas no dia seguinte, cuja edição afirmou: "Decretada a prisão do casal que espancou o bebê". A curta repercussão desse assassinato, se comparado ao Caso Isabella Nardoni, deuse principalmente em função da determinação imediata dos assassinos. Assim, diferente do fait divers examinado em seção anterior, que teve uma longa duração, a notícia "Bebê espancado até a morte, e casal é preso" é um fait divers típico, segundo a classificação de Barthes (1964), uma notícia monstruosa, em que, apesar de não haver uma "causa perturbada", estão em jogo as dramatis personae: a madrasta, o pai e a criança.

Em termos tensivos, esse fait divers é muito intenso, mas pouco extenso; não dura no eixo da temporalidade, de modo a configurar uma correlação imediatamente inversa. O caso relatado, dessa forma, possui uma estrutura muito próxima à acontecimental, no qual há uma intensidade elevada e extensidade baixa, além de ser regido pelo modo concessivo.

Apesar da mesma temática, podemos creditar a pequena permanência desse caso nas páginas do referido jornal a razões opostas que fizeram do Caso Isabella Nardoni ser portador de uma intensidade duradoura, desenvolvendo-se no eixo da extensidade. Vejamos, pois, quais são elas.

O caso do bebê espancado até a morte não possui uma causa perturbada: conheceram-se os agressores logo na primeira reportagem; logo, 
não existe uma estrutura de romance policial, pois a primeira história do inquérito se sobrepõe quase que instantaneamente à história do crime. Dessa forma, o enunciatário não é modalizado por um querer-saber, mas por um saber, o que faz com que o interesse seja logo aplacado. Diferentemente do Caso Isabella Nardoni, os envolvidos não pertencem à classe média. A vítima é negra. Isso, de certo modo, "banaliza" o caso, o que não contribui para que se forme o sentimento agregador da comoção coletiva.

As bases concessivas do caso, entretanto, são patentes: não se espera que um pai dê cabo da vida do próprio filho; a figura da criança e da madrasta estão ali, possibilitando, por intertextualidade/interdiscursividade, que se retomem estereótipos que repousam na cultura, tais como nos contos de fada apresentados. Não obstante, pelas razões expostas no paragrafo anterior, o caso tem curta duração e intensidade que decresce rapidamente, haja vista a quase nenhuma repercussão do caso em pauta.

Entre as colunas dessa mesma reportagem publicada em 19/07/2012 por $O$ Globo, abre-se um outro texto intitulado "A violência em família", cujo subtítulo é: "Morte de Isabella Nardoni, de 5 anos, jogada de sexto andar de prédio em SP, chocou o país". O texto afirma:

O episódio que teve grande repercussão no país - e até no exterior - nos últimos tempos foi o assassinato de Isabella Nardoni, de 5 anos, em São Paulo. Ela foi jogada pela janela de seu apartamento, no sexto andar de um prédio na Zona Norte, em março de 2008, depois de ser asfixiada. Dois anos depois, o pai e a madrasta de Isabella, Alexandre Nardoni e Anna Carolina Jatobá, foram condenados por homicídio triplamente qualificado a 31 e a 26 anos, respectivamente.

A menção ao assassinato de Isabella Nardoni nessa reportagem de $O$ Globo deve-se à mesma temática do caso do bebê espancado até a morte: a 
morte de uma criança causada pelo pai e pela madrasta. Contudo, para além de uma simples retomada por meio do mesmo tema, a citação do Caso Isabella Nardoni corrobora nossa tese de que há faits divers mais extensos e que, por isso, a memória em torno destes tende a permanecer. A maioria deles, entretanto, pauta-se por uma duração curta e que, em razão disso, tem como destino inexorável o esquecimento. No próximo capítulo, temos a oportunidade de teorizar a esse respeito.

\subsubsection{Reportagem do Jornal Nacional}

"Motorista de ônibus salva menina que caiu de janela em Nova York" é a manchete da reportagem exibida em 17/07/2012 pelo Jornal Nacional, que narra o salvamento de uma criança autista que caiu acidentalmente de um edifício da referida cidade norte-americana. Segue um trecho da reportagem:

Um motorista de ônibus virou herói, nos Estados Unidos. Ele se tornou celebridade no mundo inteiro por ter salvado uma garotinha que caiu da janela de um apartamento, nesta segunda-feira (16), em Nova York. Ela ficou 54 segundos dançando em cima do aparelho de ar condicionado no terceiro andar do prédio. A pequena Keyla Mccree, de 7 anos, é autista. Em um vídeo gravado por um celular ela apareceu se movimentando de um lado para o outro. No chão, de blusa azul, estava o vizinho Steven Saint Bernard. Keyla caiu e Steven conseguiu segurá-la.

Na sequência, vê-se quando a menina dançava sobre o aparelho de ar condicionado e, a seguir, a queda, quando é agarrada pelo motorista: 

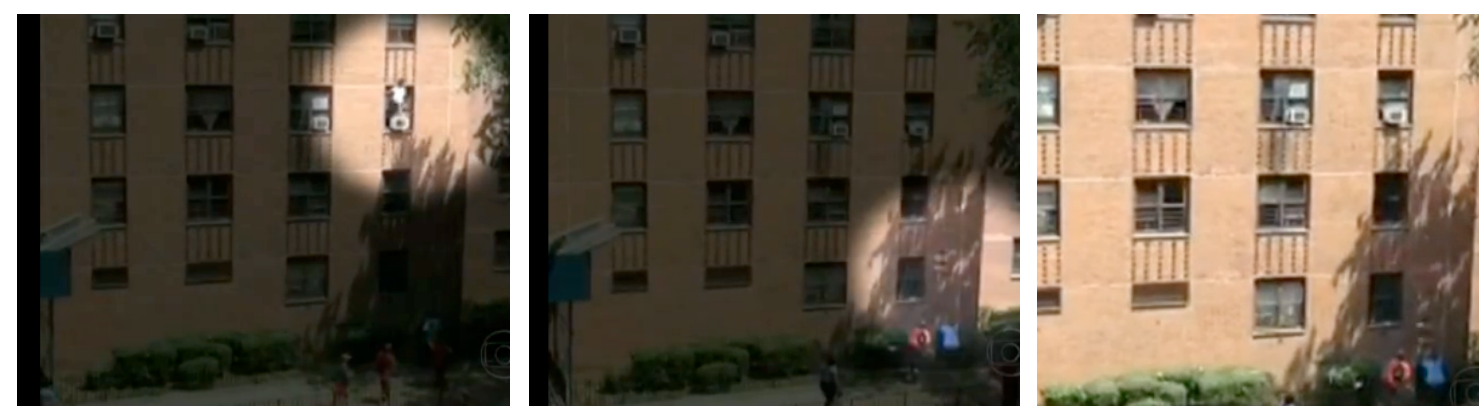

Segue outro trecho da reportagem:

O Jornal Nacional conversou nesta terça-feira (17) com ele. "Tudo o que eu pensei na hora foi: se eu não pegá-la o que vou falar para minha filha?", disse ele, que tem uma menina da mesma idade. No salvamento, Steven machucou o braço e Keyla escapou sem ferimentos.

O fait divers apresentado ancora-se na categoria barthesiana de coincidência, além de estar mais uma vez em jogo a figura da dramatis personae: uma criança autista. O modo concessivo rege o caso em questão duplamente: não se espera que uma garota autista dance à beira da janela sem proteção e que, por isso, seja vítima de queda. Mas, mais que isso: que coincidentemente estivesse passando um homem que, em fração de segundos, pôde pegá-la, evitando, assim, uma fatalidade. A tonicidade, alto impacto do relato noticioso, e o andamento, acelerado - em função da queda repentina, exibida por um vídeo feito por um telefone celular - elevam a intensidade da notícia a um alto grau.

O caso de Keyla Mccree não repercutiu na imprensa no dia seguinte, configurando-se como um fait divers de curta duração. Apesar do impacto do relato, em termos narrativos, tudo foi resolvido naquela reportagem: da queda acidental ao salvamento. O eixo da temporalidade é curto a partir de 
duas perspectivas: tanto no que se refere à queda em si quanto no que tange à sua repercussão. Nesse fait divers, portanto, assim como no anterior analisado, podemos observar uma relação inversa, em que a intensidade elevada perde logo em carga tímica, fazendo com que a fulgurância desse fato semiótico seja passageira.

\subsubsection{Outros faits divers de grande repercussão}

Para finalizar este capítulo, abordamos alguns elementos que compõem outros faits divers de grande repercussão, correlatos ao Caso Isabella Nardoni: o Caso von Richthofen e o Caso Eloá Pimentel.

No primeiro, Suzane Louise von Richthofen planeja e executa a morte dos próprios pais, com o auxílio do então namorado Daniel Cravinhos e do irmão deste, Cristian Cravinhos. No segundo, a adolescente Eloá Cristina Pimentel foi mantida em cárcere privado, junto com a amiga Nayara Silva, pelo ex-namorado, Lindemberg Fernandes Alves, por mais de 100 horas. Nayara foi liberada com vida com um tiro no rosto e Eloá, após a entrada dos policiais, não resistiu aos tiros disparados por Lindemberg Alves e morreu.

\subsubsection{Caso von Richthofen}

Tal como o Caso Isabella Nardoni, o Caso von Richthofen foi marcado por longo período de reverberação. Nos trechos das reportagens que se apresentam, pode-se comprová-lo. 
Publicada em 08/11/2002, pelo jornal Folha de S. Paulo, a reportagem intitula-se: "Saiba como foi a morte do casal Richthofen, segundo a polícia". Reproduz-se um trecho ${ }^{66}$ :

A polícia anunciou hoje que a estudante Suzane von Richthofen, 19, confessou ter planejado o assassinato de seus pais, Marísia e Manfred na madrugada no último dia 31, junto com o namorado, o autônomo Daniel Cravinhos, 21, e o cunhado Cristian Cravinhos, 26. Eles tiveram a prisão temporária de 10 dias decretada pela polícia. A confissão ocorreu após quase 12 horas de depoimentos prestados à polícia. Pressionado, Cristian teria sido o primeiro a confessar, no início da manhã de hoje. Em seguida, Suzane e o namorado também admitiram culpa.

Trechos de uma reportagem da revista Época, publicada um mês após o crime, ressalta a comoção (“o crime que chocou o país”) despertada pelo crime, e o fato de nele estar envolvida "uma adolescente bem educada, inteligente e bonita" ${ }^{67}$. Segue o excerto:

Na terça-feira passada, Suzane, Daniel e seu irmão, Cristian, de 27 anos, foram interrogados em audiência pública no Plenário do Fórum da Barra Funda, em São Paulo. Diante de um juiz, os três relataram em detalhes como planejaram o assassinato de Manfred e sua mulher, Marísia. O interrogatório pouco acrescentou ao que já se sabia do crime que há um mês chocou o país por envolver uma adolescente bem educada, inteligente e bonita que se revelou capaz de premeditar a morte dos próprios pais (itálicos nossos).

\footnotetext{
${ }^{66}$ Disponível em: http://www1.folha.uol.com.br/folha/cotidiano/ult95u62515.shtml. Acesso em 9 abr. 2013.

${ }^{67}$ Disponível em: http://revistaepoca.globo.com/Revista/Epoca/0,EDR54308-5990,00.html. Acesso em 9 abr. 2013.
} 
Além de ter sido marcado por uma cobertura midiática constante nas primeiras semanas que sucederam ao crime, como também foi o Caso Isabella Nardoni, o fait divers em pauta foi objeto de reportagens que remetiam ao assassinato mesmo após as primeiras semanas ou meses. Isso pode ser verificado na notícia publicada pelo jornal Folha de S. Paulo, em 31/10/2003, intitulada "Assassinato do casal Richthofen completa um ano"68.

Há exatamente um ano, dia 31 de outubro de 2002, o assassinato do casal Marísia e Manfred von Richthofen, inicialmente tratado como suspeita de latrocínio (roubo seguido de morte), se transformou em um crime familiar que surpreendeu o país. A filha do casal, Suzane, então com 18 anos, o namorado dela, Daniel Cravinhos, e o irmão dele, Cristian, foram presos dias depois sob acusação de planejarem e executarem o crime. Os três confessaram participação. O crime ocorreu na casa das vítimas, na região do Brooklin, bairro nobre de São Paulo.

A mesma reportagem retoma as circunstâncias do crime:

O crime ocorreu na madrugada de 31 de outubro do ano passado. [...] Manfred e Marísia foram atacados enquanto dormiam. Foram golpeados com bastões na cabeça e em partes do corpo ainda na cama. Suzane diz que não participou diretamente das mortes.

Em 22/07/2010, o site de notícias G1 publica: “Condenação de Suzane Richthofen pela morte dos pais completa 4 anos" ${ }^{69}$. Assim, o julgamento em que os acusados foram condenados, em 2006, ainda ecoa quatro anos depois:

\footnotetext{
${ }^{68}$ Disponível em: http://www1.folha.uol.com.br/folha/cotidiano/ult95u84892.shtml. Acesso em 9 abr. 2013.

${ }^{69}$ Disponível em: http://g1.globo.com/sao-paulo/noticia/2010/0J/condenacao-de-suzane-rich thofen-pela-morte-dos-pais-completa-4-anos.html. Acesso em 9 abr. 2013.
} 
O julgamento de Suzane von Richthofen e dos irmãos Daniel e Cristian Cravinhos de Paula e Silva terminou na madrugada do dia 22 de julho de 2006. Há quatro anos, eles foram submetidos ao júri popular pelas mortes ocorridas em 2002 dos pais de Suzane, o engenheiro Manfred e a psiquiatra Marísia, pais de Suzane. Depois de cinco dias de julgamento, eles acabaram condenados pelo duplo homicídio. Os três cumprem pena atualmente em presídios de Tremembé, a $147 \mathrm{~km}$ da capital paulista.

Não é nosso objetivo, em relação a estes últimos faits divers (Caso von Richthofen e Caso Eloá Pimentel), empreender uma análise detalhada, mas, fundamentalmente, apontar elementos que indiquem o porquê de terem tido uma cobertura midiática duradoura, assim como teve o Caso Isabella Nardoni.

Desse modo, no que tange ao Caso von Richthofen, tem-se uma adolescente de classe média alta, "bem educada, inteligente e bonita", segundo textualmente afirmou a revista Época, que planejou e executou junto com o então namorado e o irmão deste a morte dos próprios pais. Um assassinato, como se viu, extremamente violento, cujo objetivo era livrar-se dos pais para, então, usufruir da herança e da companhia do namorado sem quaisquer impedimentos.

O fait divers como se vê, ancora-se numa base concessiva: a filha que assassina os próprios pais. Como diria Zilberberg, embora não fosse possível, aconteceu! O impacto causado pelas circunstâncias da morte - as vítimas foram atacadas com barras de ferro na cabeça enquanto dormiam - constitui um fato semiótico extremamente tônico. 
Diferente do Caso Isabella Nardoni, no entanto, logo puderam ser determinados os culpados pelo crime, o que poderia aplacar a intensidade desse fato, tal como na notícia do bebê espancado até a morte. Todavia, singulariza o fait divers enfocado neste momento, tal como no Isabella Nardoni, o perfil da assassina: branca, bonita pela axiologia vigente, e de classe média alta ser mentora de um crime horrendo, cujas vítimas foram os próprios pais, para beneficiar-se da herança. Vê-se, assim, que a combinação de determinados elementos - aqui, de natureza figurativa e, portanto, ideológica (Cf. FIORIN, 2005a) - são fundamentais para a manutenção do interesse do enunciatário.

Poder-se-ia também dizer que, para além da carga tímica de um fato semiótico de base acontecimental, outros elementos que se somam ou não a ele são responsáveis pela duração desse fato no eixo da temporalidade, possuidor de uma intensidade que, embora, ao final, possa ser decrescente a partir da saturação, essa curva descendente é lenta e gradual.

Pressupõe-se, além disso, que, se há o interesse do enunciatário em torno de uma notícia monstruosa e daquelas que a sucederam, subjaz a esse interesse, a essa expectativa, uma intensidade regente, uma "ebulição de afetos", que, via de regra em casos como este, manifesta-se pela comoção de um actante coletivo, tal como mostramos em subseção anterior, exemplificado pelo trecho "o crime que chocou o país” veiculado pela revista Época. 


\subsubsection{Caso Eloá Pimentel}

O Caso Eloá Pimentel, assim como o Isabella Nardoni e o von Richthofen, teve uma cobertura midiática que se estendeu por vários dias e semanas. A diferença é que o acontecimento motivador de sua reverberação foi duradouro: o sequestro e o cárcere privado de Eloá e de sua amiga duraram mais de 100 horas, sendo acompanhados ao vivo por diversos veículos de comunicação.

Em 16/10/2008, ainda durante o sequestro, o jornal Folha de S. Paulo publicou reportagem intitulada "Mais longo caso de cárcere privado em SP completa 3 dias; negociações prosseguem" "70. Segue um trecho da notícia:

O ajudante de produção Lindemberg Fernandes Alves, 22, mantém a ex-namorada - de 15 anos - refém desde as $13 \mathrm{~h} 30$ da última segunda-feira (13) em um prédio em Santo André (Grande São Paulo). As negociações prosseguem, e, na manhã desta quinta, a jovem que também havia sido rendida e foi libertada na noite de terça voltou ao local para conversar com Alves. Ela estaria acompanhada de um irmão da menina mantida refém. [...] Ontem, no início da tarde, a mãe da garota se desesperou ao vê-la aparecer na janela. Ela gritou bastante, mas foi contida por amigos. Chorando bastante, a adolescente gesticulou para pedir calma à mãe enquanto usava uma corda feita com lençóis para pegar alimentos.

A reportagem narra ainda que:

Inconformado com o fim do namoro, Alves invadiu o apartamento onde mora a ex-namorada [...]. De acordo com familiares, eles namoraram por três anos e terminaram há um mês, por iniciativa dele. Ela teria se recusado a reatar. Ele está

\footnotetext{
${ }^{70}$ Disponível em: http://www1.folha.uol.com.br/folha/cotidiano/ult95u45683 6.shtml. Acesso em 10 abr. 2013.
} 
armado com dois revólveres e tem um saco cheio de balas, segundo a polícia. Desde o início do seqüestro [sic], ele disparou quatro tiros em direção às pessoas que acompanham a movimentação - dois na noite de segunda e dois na terçafeira.

O portal de notícias G1 noticia o fim trágico do sequestro na manchete "Jovem baleada após seqüestro $[$ sic $]$ no ABC tem morte cerebral, diz equipe médica" 71 . O subtítulo informa ainda que: "Após ser mantida refém por mais de 100 horas, Eloá levou tiro na cabeça. Testes apontaram que cérebro não tem atividade". Apresenta-se um fragmento:

A jovem Eloá Cristina Pimentel, de 15 anos, que foi mantida refém durante mais de 100 horas pelo ex-namorado em Santo André, no $\mathrm{ABC}$, teve morte cerebral confirmada às $23 \mathrm{~h} 30$ deste sábado (18), segundo informou o secretário de Saúde do município, Homero Nepomuceno Duarte. [...] Segundo os médicos, Nayara Silva, 15 anos, amiga de Eloá que também foi baleada, segue estável e sem alterações no estado de saúde. [...] O Grupo de Ações Táticas Especiais (Gate) explodiu a porta e deteve Lindemberg. A adolescente Nayara deixou o apartamento andando, enquanto Eloá, carregada, foi levada inconsciente para o hospital. $O$ seqüestrador [sic], sem ferimentos, foi levado para a delegacia e, depois, para a cadeia pública da cidade.

O portal de notícias ressalta a motivação passional do crime:

As duas adolescentes ficaram feridas no desfecho de um seqüestro [sic] que durou mais de 100 horas. Na segunda-feira (13), por volta das $13 \mathrm{~h} 30$, motivado por ciúmes, Lindemberg Alves, de 22 anos, antes considerado calmo pelos amigos, invadiu o apartamento da ex-namorada e chegou a manter quatro reféns (itálicos nossos).

\footnotetext{
${ }^{71}$ Disponível em: http://g1.globo.com/Noticias/SaoPaulo/0,,mul804318-5605,00-jovem+balea $\mathrm{da}+$ apos + sequestro + no + abc + tem + morte + cerebral $+\mathrm{diz}+$ equipe + medica.html/. Acesso em: 10 abr. 2013.
} 
Notícias sobre o Caso Eloá Pimentel repercutiram inclusive internacionalmente. O periódico espanhol El País destacou a comoção em torno da morte da adolescente, além da espera tensa motivada durante o tempo em que Eloá e Nayara foram mantidas reféns ${ }^{72}$ :

O Brasil amanheceu hoje comovido por um caso que manteve o país em suspense durante toda a semana. Lindenbergue [sic] Fernandes, um jovem de 22 anos, sequestrava na segundafeira passada sua ex-namorada, Eloá Cristina Pimentel, de 15 anos, quando ela estava estudando com três amigos em sua casa. O rapaz, inconformado com a recente ruptura de uma relação que havia durado dois anos, surgiu armado no apartamento, liberou dois amigos e reteve a sua ex-namorada e a sua amiga Nayara Silva, também de 15 anos (itálicos nossos).

Outro motivo, até então inédito, da grande repercussão do caso em questão foi a participação da mídia como uma espécie de mediadora entre o sequestrador e a polícia. Segundo o Portal Imprensa ${ }^{73}$,

O seqüestro [sic] começou na segunda-feira (13). Já na quarta (15), quando o caso já durava mais de 48 horas, a Rede TV! entrevistou Lindemberg Alves, por meio do repórter Luiz Guerra. Mais tarde, a repórter Zelda Mello, da TV Globo, também usou do artifício e ligou para o seqüestrador [sic]. A entrevista foi exibida no jornal "SPTV". A Folha Online também ligou e publicou matéria com entrevista de Alves. [...] A jornalista Sônia Abrão, apresentadora do programa "A Tarde é Sua”, conversou ao vivo [...] com Alves e Eloá por telefone.

\footnotetext{
72 Disponível em: http://internacional.elpais.com/internacional/2008/10/19/actualidad/122 4367206_850215.html/.Acesso em 10 abr. 2013.

${ }^{73}$ Disponível em: http://portalimprensa.uol.com.br/colunistas/colunas/2008/10/18/imprensa3 11.shtml/. Acesso em 10 abr. 2013.
} 
A espetacularização de um sequestro com final trágico fez do Caso Eloá Pimentel uma espécie de reality show durante as 100 horas de cárcere. Segundo Carvalho et al. (2010, p. 120) a respeito desse episódio, "aos poucos, emissoras de TV passam a interromper suas programações com boletins curtos. Os números da audiência cresciam cada vez que o caso ocupava espaço". Assim, o enunciatário "telespectador", por meio de uma espera tensa, acompanhava o desenrolar daquela situação de cárcere privado, minuto a minuto - ao vivo -, do qual poderiam sair vivas ou mortas, a qualquer momento, as reféns. Tal característica incomum, em que a mídia além de reportar o fato, intervém diretamente nele (cujas implicações éticas não serão aqui objeto de análise), contribuiu para que o caso repercutisse tanto em termos de espacialidade quanto em termos de temporalidade.

Entretanto, para além dessa particularidade, cabem algumas considerações. Conforme se viu, as paixões, se não são motivadoras, estão presentes de alguma maneira no fait divers. Assim, como foi demonstrado, esse efeito patêmico perpassa o Caso Isabella Nardoni, o von Richthofen, o do bebê espancado até a morte, o da queda acidental da garota autista e, ainda, o caso agora sob exame. Tal efeito se refere tanto à paixão que move o sujeito do fazer quanto à(s) paixão(ões) coletiva(s) despertada(s) na audiência. Ademais, todos os casos analisados ancoram-se no modo concessivo, aquele do fortuito, do inesperado, em suma, do acontecimento. Com efeito, afirma Fontanille (2007, p. 188), “a racionalidade própria do universo da paixão é aquela do acontecimento: [...] ele advém e afeta aquilo que está diante dele, para quem ou para em quem ele advém”. Por isso, cumpre reafirmar a estreita ligação entre fait divers, paixões e concessão. 
O presente capítulo procurou empreender uma análise mais detida do Caso Isabella Nardoni para, depois, apresentar uma leitura semiótica de outros faits divers com o intuito de que fossem observadas/comparadas algumas (in)variantes subjacentes a eles. Assim, no último capítulo, com base na teoria em que nos ancoramos e nas análises realizadas, apresenta-se uma abordagem tensiva do fait divers. 


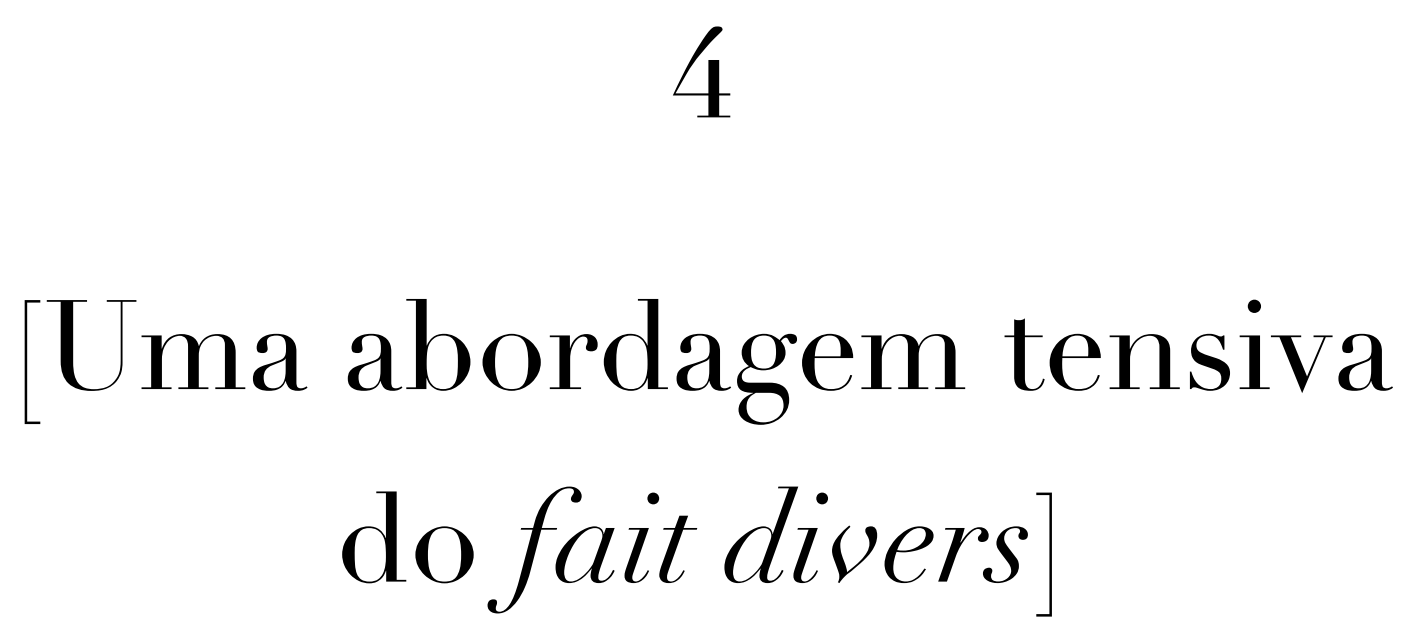

"Uma descoberta localizada na superficie do texto, uma inconsistência que aí se perceba não deixam de ressoar em profundidade na teoria." Algirdas Julien Greimas \& Jacques Fontanille 


\subsection{SEMIÓTICA: teoria e aplicação}

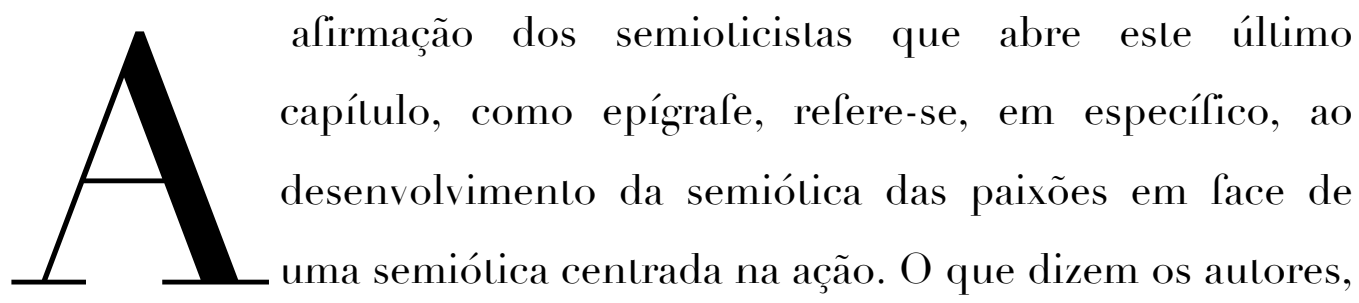
no entanto, remete, em sentido lato, ao próprio projeto semiótico, construído continuamente, a cada "descoberta localizada na superfície do texto", a cada "inconsistência que aí se perceba", para fazer uso das mesmas expressões por eles utilizadas. Por isso, a teoria semiótica é "dedutiva quanto à forma que assume o desdobramento de seu percurso, a metodologia semiótica é 'indutiva' na ocasião da exploração de sua instância ad quem e 'hipotética' em suas formulações epistemológicas $\left[\begin{array}{ll}a & q u o\end{array}\right]^{74 "}$ (GREIMAS; FONTANILLE, 1993, p. 10). Desse modo, se a análise parte de um arcabouço teórico, é graças a ela que outros desenvolvimentos vêm se juntar à teoria, seja de forma polêmica seja de forma contratual. Teoria e aplicação, dessa maneira, não são instâncias em separado, mas duas faces do mesmo projeto semiótico.

\subsection{O FAIT DIVERS À LUZ DA TENSIVIDADE}

A partir das análises realizadas no Capítulo 3 e da teoria exposta no Capítulo 2, ficam mais evidentes algumas (in)variantes que subjazem ao fait divers, objeto de reflexão deste último capítulo. Conforme dissemos no item

\footnotetext{
${ }^{74}$ Embora conste o termo "ab que" na edição de Sémiotique des passions (1991, p. 7), o qual, por sua vez, também foi registrado na tradução brasileira, a expressão latina que corretamente se opõe a "ad quem" é "a quo". A primeira se refere a uma instância superior, enquanto a segunda, a uma inferior.
} 
"Justificativa", na Introdução desta tese, cabe observar se, na atualidade, o fait divers - como categoria de relato jornalístico - é passível de acolher novas proposições teóricas. Pelo que vimos demonstrando até agora, a reposta é afirmativa. Reiteramos que essa teorização do fait divers a que nos referimos remonta à vertente tensiva da semiótica.

Para Barthes (1964, p. 195), o fait divers não possui duração. Em nota de rodapé, na mesma página, o semiólogo assevera: "Certos faits divers se desenvolvem por vários dias ou até meses; isso não rompe sua imanência constitutiva, pois implicam sempre uma memória curta" (itálicos nossos). Assim, segundo o autor, o fait divers não possui nem temporalidade, nem memória (ou uma memória curta, isto é, tende a desaparecer).

A nosso ver, ao contrário, duração e memória são categorias que subsumem o fait divers. Desse modo, consideramos inicialmente a categoria duração para, em seguida, discorrer sobre a categoria memória. Além dessas, apontamos para o elemento constitutivo paixões que, invariavelmente, compõe esse tipo de relato jornalístico. Cabe complementar que tais (in)variantes depreendidas pelo corpus são balizadas pelas esquizias tensivas primordiais intensidade e extensidade. A partir delas, pode-se estabelecer o que chamamos de abordagem tensiva do fait divers.

\subsubsection{Duração}

Segundo vimos nas análises, a tonicidade aplicada sobre a temporalidade aumenta a duração, criando um efeito de persistência (Cf. ZILBERBERG, 2011a). Tal persistência, no âmbito de nossa pesquisa, remete, no nível do discurso, ao encadeamento, à sequencialidade de 
reportagens de um mesmo tema, por exemplo, o Caso Isabella Nardoni ou o Caso von Richthofen. A manutenção de um mesmo fato sob os holofotes da mídia, no nível figural, por sua vez, refere-se à "extensivização" do intenso, e não à continuidade, uma vez que esta remeteria, no nível da narrativa, à conjunção. O acontecimento, que caracteriza o fait divers, por seu turno, define-se por ser essencialmente uma ruptura, uma quebra, em suma, uma disjunção no nível da narrativa.

Dessa forma, conforme exposto nas análises sobre o Caso Isabella Nardoni, este se revelou um fait divers de natureza serial, sequencial, extensa. Cabe ratificar, ademais, que o que moveu esta pesquisa foi buscar nos mecanismos do discurso jornalístico o porquê de certos faits divers durarem mais ou menos por meio de uma estratégia que denominamos de “extensivização" do intenso, o que tem a ver, ainda, com o adiamento da atenuação. Por isso, a primeira categoria de que se deve tratar é a duração.

Um fait divers, aqui tomado como um fato semiótico de bases concessivas, pode ter uma cobertura midiática de duração que pode variar de curta (pontual) a longa, entendendo tais termos como polos opostos de um continuum. Uma invariante, no entanto, é que todo fait divers é portador de uma elevada carga tímica, um grau de intensidade que, muitas vezes, é paroxístico. Essa intensidade tende a decrescer em algum momento no transcurso da temporalidade. Desse modo, estão em jogo algumas situações observadas no corpus:

(1) Uma intensidade que, se de início já é alta, amplia-se, chegando à saturação, tal como pudemos observar no tocante à análise do Caso Isabella Nardoni; 
(2) A manutenção temporária da intensidade num nível elevado/paroxístico, estável, apesar da temporalidade, que, em algum momento vai perder força, mas não necessariamente extenuar-se, conforme ocorre em outros casos de grande repercussão, tal como o caso Von Richthofen e Eloá Pimentel;

(3) O decréscimo lento da intensidade pela temporalidade;

(4) O decréscimo rápido da intensidade pela temporalidade, tal como demonstrou a notícia do bebê espancado até a morte ou a da garota com autismo que caiu da janela e foi salva por um passante.

Os três primeiros casos são portadores de longa duração, com maior extensidade, portanto; o último, por sua vez, mais comum, tem duração curta.

Cumpre afirmar, ademais, que a saturação é o ponto máximo da intensidade. Um fait divers correlato ao acontecimento zilberberguiano parte dessa unidade e visa à atenuação que, por sua vez, tem como destino a diminuição, podendo chegar, por fim, à extenuação.

Um tipo de fait divers como o Caso Isabella Nardoni, por seu turno, penetra no campo de presença do sujeito com uma intensidade elevada e que, via recrudescimento, chega a saturar-se. A partir desse ponto, passa-se à atenuação e, posteriormente, à diminuição. Não se pode dizer, entretanto, que chega a extenuar-se, o que significaria perder toda a sua carga tímica.

Vimos ainda que a maioria dos faits divers, tal como a notícia do bebê espancado, tem uma curva nitidamente descendente, perdendo a intensidade, extenuando-se num curto espaço de tempo. 
A partir da saturação, entretanto, invariavelmente, todos os faits divers são marcados por uma curva descendente. O que vai diferir, nesse caso, é a velocidade do decréscimo de carga tímica em função do aumento da temporalidade.

Assim, em geral, o fait divers é portador de uma curta duração. No entanto, faits divers que, pela semântica extensiva, poderíamos denominar "raros", por serem extensos e tônicos, possuem uma duração que extrapola uma ou duas edições de um programa jornalístico, estendendo-se - com considerável carga tímica - por um longo período. Tal "extensivização" do intenso é, portanto, o que caracteriza um fait divers dessa natureza.

\subsubsection{Memória}

Considerar a existência de uma duração variável do fait divers conduz a uma segunda categoria que, para nós, também abrange esse tipo de notícia: a memória. Assim, se um fato semiótico de carga tímica elevada permanece no campo de presença do sujeito (enunciatário) por um longo período, a memória em torno desse fait divers tende a permanecer, em função do longo período em que o sujeito semiótico foi afetado por aquele objeto.

Noutros termos, um fait divers que se realizou e cuja carga tímica, ainda, de alguma forma, subsiste, entrará nas vias da potencialização. Com efeito, afirma Zilberberg (2007, p. 23) que "a potencialização está relacionada à memorização" . Assim, aqueles faits divers que se mantêm potencializados de forma tônica estão diretamente ligados à memória, ao passo que aqueles que se potencializam de forma átona são esquecidos parcial ou totalmente. 
Para Babo-Lança (2012, p. 55), “as mídias assumem um papel na construção da memória coletiva e uma vocação de cariz historiográfico, no sentido que elegem os acontecimentos dignos de memória". De forma correlata, Zilberberg (2011a, p. 193) declara que:

\begin{abstract}
Atendo-se ao que se costuma chamar de "historietas", o jornal registra dia a dia os fatos menores que a pequenez do intervalo adotado the proporciona, enquanto a cronografia, ao se valer de um intervalo por vezes considerável, desacelera a passagem do tempo, quando não a suspende, $\mathrm{e}$ só seleciona os momentos considerados por uma ou outra razão "fortes", os "acentos de sentido", os quais encadeados uns aos outros, vão constituir ou parecer constituir a "grande história".
\end{abstract}

A asserção do semioticista refere-se à diferença entre o banal do jornalismo diário e de fatos que, por algumas razões, entram para o rol da História, ou seja, os grandes acontecimentos que marcaram época. É possível, entretanto, valermo-nos da citação acima no sentido de elucubrarmos uma espécie de hipotética enciclopédia do fait divers. Nela, evidentemente, figurariam aqueles com alto grau de intensidade. Entretanto, estariam presentes, sobretudo, os que, além de um alto grau de intensidade, foram marcados por uma grande duração, a qual, por sua vez, remete à memória.

Assim, como foi dito, a grande extensidade temporal em que se desenvolveu o Caso Isabella Nardoni, aliada à sua alta carga tímica, caracteriza esse fait divers como do tipo "raro", segundo os termos da semântica extensiva, uma vez que é tônico e extenso. Desse modo, poderíamos considerar faits divers dos quais se esquecem facilmente, mas também aqueles em torno dos quais a memória permanece viva. Os primeiros se obliteram sob a sombra dos faits divers do dia seguinte. 
Entretanto, no outro polo desse continuum, estão aqueles faits divers cuja chama não se apaga por completo; reminiscentes, permanecem tônicos na memória coletiva.

Para nos mantermos no Caso Isabella Nardoni, a notícia veiculada pelo jornal $O$ Globo sobre o bebê espancado até a morte, que abriu uma nota dentro da reportagem principal para referir-se àquele fait divers, é um indício inequívoco de que a memória em relação a ele subsiste nas vias da potencialização. Podemos ainda comprová-lo com a seguinte notícia veiculada em 24/01/2013 pela Folha de S. Paulo, em cujo título se lê: "Peça de teatro sobre caso Isabella Nardoni estreia em SP em março" ${ }^{75}$. A notícia informa que:

Conhecido como "caso Isabella", o assassinato da menina Isabella Nardoni, aos cinco anos de idade, servirá de base a uma encenação teatral da companhia Os Satyros. Escrito por Lucas Arantes, o texto "Edifício London" será dirigido por Fabrício Castro com coordenação de Rodolfo García Vázquez. A estreia está prevista para março, em São Paulo. Isabella morreu no dia 29 de março de 2008, ao ser jogada do sexto andar do prédio, edifício London, onde moravam o pai, Alexandre Alves Nardoni, e a madrasta da menina, Anna Carolina Trotta Jatobá. Eles foram condenados, em março de 2010, por homicídio triplamente qualificado e fraude processual (por ter alterado a cena do crime). A peça, no entanto, não faz uma reconstituição precisa do crime.

Cabe ainda citar a reportagem publicada pelo portal de notícias G1, apresentada no capítulo anterior, cujo título é "Condenação de Suzane Richthofen pela morte dos pais completa 4 anos". Assim, pode-se dizer que esse fait divers também permanece potencializado tonicamente.

\footnotetext{
${ }^{75}$ Disponível em: http://www1.folha.uol.com.br/ilustrada/1220042-peca-de-teatro-sobre-caso -isabella-nardoni-estreia-em-sp-em-marco.shtml/. Acesso em: 13 abr. 2013.
} 
Por conseguinte, se formos conceber um compêndio de faits divers brasileiros dos últimos 20 ou 30 anos, correlatos aos acontecimentos que compõem a História, segundo Zilberberg (2011a), e, naturalmente, deixando de lado os triviais, tal obra seria composta de poucas páginas. E por que razão? Da mesma forma que a História age pelo princípio da triagem, também é assim que operaria a sintaxe extensiva de uma possível enciclopédia de faits divers brasileiros das últimas duas ou três décadas.

\subsubsection{Paixões}

Faits divers com longa duração, persistentes, devido à projeção da tonicidade na temporalidade, são marcados, de maneira geral, pela paixão da comoção pública. Esse "sentir/sofrer-comum", como mostra Landowski (2004), conforma o social, um actante coletivo, cuja amálgama é a pura estesia. Assim, a comoção social em torno de faits divers é outra invariante que pudemos verificar no/pelo corpus.

Não apenas de comoção, entretanto, é feito um relato jornalístico dessa natureza. Neste estudo podemos ratificar seu forte caráter ligado a outras paixões. Conforme vimos, são temas recorrentes desse tipo de relato crimes passionais, chantagens, agressões; em suma, fatos caracterizados por um forte quantum emocional. Pela sintaxe juntiva o fait divers é marcado pela concessão, uma vez que remete a eventos da ordem do inesperado, do fortuito.

Cumpre dizer, ademais, que paixões relativas ao fait divers não se referem apenas aos atores do texto-enunciado, ou à relação entre enunciador e enunciatário. Conforme pudemos demonstrar na seção dedicada às 
relações intertextuais e interdiscursivas, o fait divers se relaciona a outras narrativas estocadas em outros textos e/ou no imaginário humano, em que actantes sofrem ou fazem sofrer, movidos, em geral, por paixões malevolentes. No nível discursivo, tais actantes se actorializam sob a forma de uma "madrasta" ou uma "criança indefesa", resgatáveis facilmente por interdiscursividade ou intertextualidade.

Dessa forma, pode-se perceber que as paixões que marcam o fait divers o constituem tanto no que se refere aos atores do enunciado (em que se destacam as paixões malevolentes) quanto nas relações que se estabelecem entre atores da enunciação (principalmente a paixão da comoção), mas também nas relações intertextuais e interdiscursivas que se podem estabelecer entre um dado fait divers e outros textos/discursos.

Logo, pode-se dizer que as categorias duração e memória, além do elemento constitutivo paixões, depreendidos da análise do corpus desta pesquisa, mostram que, diferente do que postula Barthes (1964), o fait divers, por meio de uma perspectiva tensiva, não prescinde, a nosso ver, de memória e de duração. Assim, o fait divers pode ser portador de duração e ficar potencializado de forma tônica na memória coletiva, mas isso não significa que necessariamente sempre o será. Cabe acrescentar que entendemos as categorias duração e memória como polos de uma gradação, ou seja: do menos durativo ao mais durativo; do menos memorável ao mais memorável.

Por conseguinte, as análises desenvolvidas nesta tese nos permitem aventar um modelo que não aprisiona o fait divers numa temporalidade obrigatoriamente curta e numa memória igualmente breve. Pensar o fait divers pela ótica da tensividade possibilitou-nos, pois, correlacionar sensível 
e inteligível, intensidade e extensidade, de forma "elástica", contínua, complexa - apanágio da teoria em que nos apoiamos. Assim, a abordagem tensiva que postulamos para essa categoria jornalística é apta tanto para abarcar faits divers do tipo "raro" quanto do tipo "comum".

\subsection{TIPOLOGIA TENSIVA DO FAIT DIVERS}

Vimos insistindo na diferença entre faits divers "raros" e "comuns", a partir da semântica extensiva. Cabe dizer ainda que um fait divers pode ter uma intensidade variável sendo, por isso, mais átono ou mais tônico. Relatos trágicos, mortes em geral, têm maior tonicidade que notícias relacionadas a eventos da ordem do inesperado, mas não necessariamente tônicos. Para retomar um exemplo apresentado no Capítulo 1, a informação sobre alguém que ganha na loteria por mais de uma vez configura um fait divers átono. Assim, podemos postular a existência de faits divers tônicos e faits divers átonos (ou mais tônicos ou mais átonos, a partir de uma perspectiva gradual). Os primeiros se dividem em tônicos e concentrados, tal como a notícia do bebê espancado até a morte, e em tônicos e extensos, tal como o Caso Isabella Nardoni. A seguir, podemos representar graficamente essa classificação: 


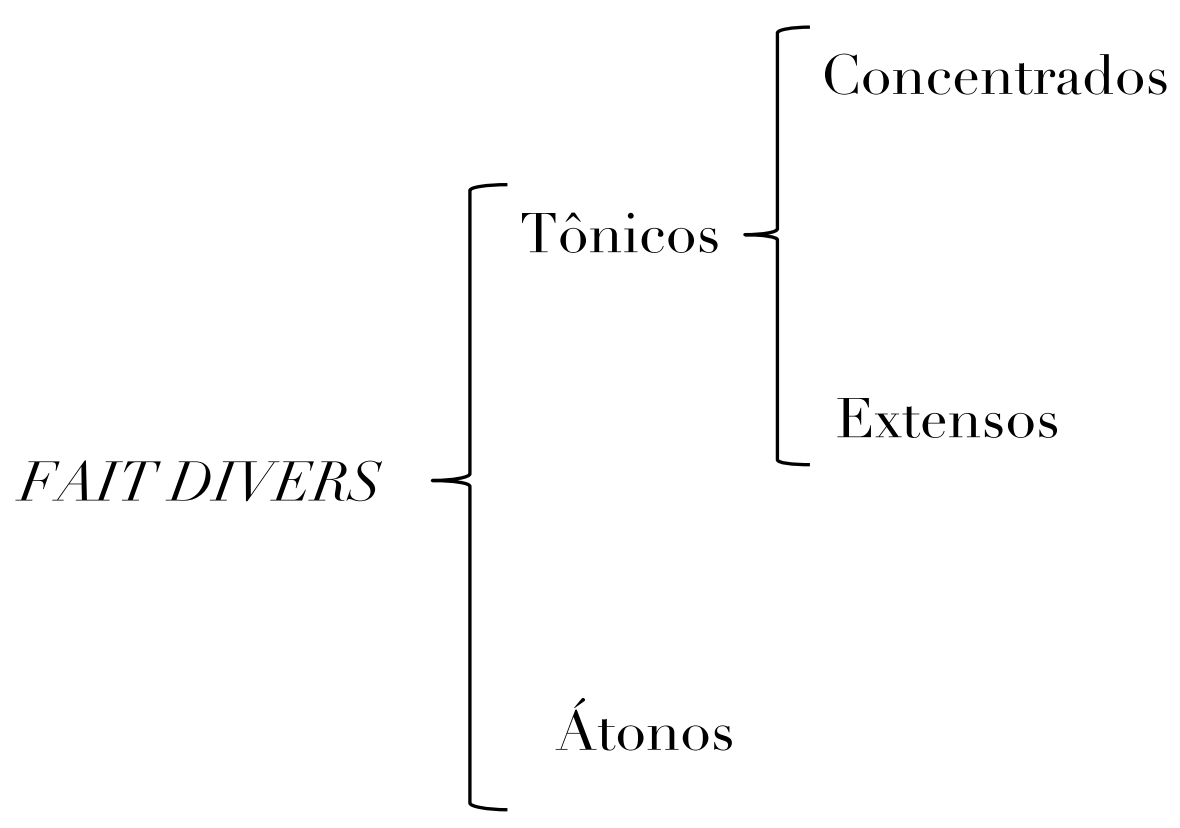

A partir dessa esquematização, torna-se possível uma classificação a partir do par "raro/comum”, da semântica extensiva:

\begin{tabular}{|c|c|}
\hline FAITS DIVERS COMUNS & FAITS DIVERS RAROS \\
\hline Átonos & Tônicos e extensos \\
\hline Tônicos e concentrados & \\
\hline
\end{tabular}

Assim, se a maioria dos faits divers se enquadra na primeira coluna, dos comuns, seja por possuírem menor tonicidade ou por serem tônicos e concentrados, os raros, por sua vez, diferenciam-se pela maior tonicidade e extensão temporal por que são caracterizados. 


\subsection{FAIT DIVERS, ACONTECIMENTO E EXERCÍCIO}

A duração, como se viu, evidenciou-se uma categoria do fait divers, depreendida por meio da estratégia discursiva que denominamos “extensivização" do intenso. Essa estratégia caracteriza uma engrenagem que articula dois regimes discursivos de que fala Zilberberg (2007, p. 25), a saber: o acontecimento e o exercício. Retomemos a tabela em que o autor define tais regimes por meio de três termos, cada qual correspondente a um modo, tal como se vê a seguir:

\begin{tabular}{|c|c|c|}
\hline $\begin{array}{c}\text { determinados } \rightarrow \\
\text { determinantes } \\
\downarrow\end{array}$ & ACONTECIMENTO & EXERCÍCIO \\
\hline modo de eficiência & sobrevir & pervir \\
\hline modo de existência & apreensão & foco \\
\hline modo de junção & concessão & implicação \\
\hline
\end{tabular}

Zilberberg (2011a, p. 271) ainda sobredetermina os termos "sobrevir" (relativo ao acontecimento) e "pervir" (referente ao exercício) pelos termos andamento, temporalidade e número, conforme se reproduz a seguir: 


\begin{tabular}{|c|c|c|}
\hline $\begin{array}{c}\text { definidos } \rightarrow \\
\text { definidores }\end{array}$ & SOBREVIR & PERVIR \\
$\downarrow$ & celeridade & lentidão \\
\hline andamento & $\begin{array}{c}\text { instantaneidade e } \\
\text { indivisibilidade }\end{array}$ & $\begin{array}{c}\text { duratividade e } \\
\text { progressividade }\end{array}$ \\
\hline temporalidade & em uma só vez & em tantas vezes \\
\hline número & & \\
\hline
\end{tabular}

Pelo que observamos nas análises referentes ao fait divers de longa duração, o sobrevir e o pervir tendem a uma sobreposição de modo a se formar um termo complexo. Vejamos, pois, como isso é possível.

No que tange ao andamento, esse tipo de fait divers se instaura com celeridade que, devido à longa duração, em algum momento, passa a tender à lentidão. Em relação à temporalidade, tal como o acontecimento zilberberguiano, ele é instantâneo; no entanto, a partir dessa instantaneidade, é marcado pela duratividade, que é exatamente o que marca um fait divers extenso. No que concerne ao número, ele entra no campo de presença do sujeito de uma só vez. Como exemplo, podemos citar o fato motivador do crime do Caso Isabella Nardoni: seu assassinato. Entretanto, por meio do que chamamos de microacontecimentos e da reverberação do acontecimento inicial e de seus microacontecimentos, o "em uma vez só” passa a se realizar "em tantas vezes".

A apreensão, característica do acontecimento, ou seja, aquilo que toma o sujeito, invade-o, deixa-o sem a sua voz (Cf. ZILBERBERG, 2011a, p. 189), aplica-se ao fait divers que podemos chamar, pela semântica extensiva, de "comum". O fait divers de longa duração, por sua vez, estabelece um elo 
com o foco, que é quando o sujeito consegue elaborar, por meio da temporalidade, o sensível paroxístico, convertendo-o, ao menos parcialmente, em inteligível. Assim, por meio da duração, o fait divers que se estende no eixo da temporalidade articula sensível e inteligível, de modo a também respaldar nossa tese de que esse tipo de relato noticioso estabelece uma ponte entre os estilos discursivos acontecimento e exercício.

Por fim, quanto ao modo de junção de cada um desses regimes discursivos, podemos afirmar que o fait divers "comum" tem bases concessivas, assim como também tem o fait divers "raro". Entretanto, este último, justamente por durar, uma vez que se constitui como uma presença constante de um mesmo fato semiótico no campo perceptivo do sujeito, seja por reverberação seja por microacontecimentos, conforme foi visto nas análises, move o acontecimento em direção à rotina. Dito de outro modo, o acontecimento não chega a ser absorvido pela cotidianidade, pelo exercício, o que significaria trocar o modo concessivo pelo implicativo, mas cria-se uma tensão entre esses dois regimes a partir da atenuação do intenso paroxístico.

Assim, o fait divers durativo, "raro", por meio da estratégia discursiva que "extensiviza" o intenso, articula, coloca em relação os regimes discursivos do acontecimento e do exercício a partir de um ponto de vista tensivo e, portanto, complexo. 
[À guisa de conclusão]

"Tendo o sensivel ganhado paulatinamente a primazia no concurso da emergência da significação, o afeto passa de efeito à 'razão' das razões do sentido."

Waldir Beividas 


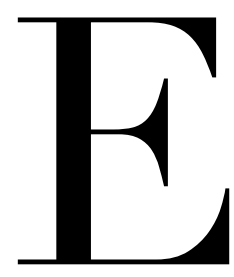

studar o fait divers pela ótica da tensividade foi o objetivo desta tese. Fizemo-lo, inicialmente, analisando a cobertura realizada pelo Jornal Nacional sobre o Caso Isabella Nardoni. Tal fait divers possui características anômalas, no que respeita à duração (uma vez que a maioria deles não costuma repercutir), mas não no que tange à sua principal característica: é um fato semiótico de bases concessivas, conforme demostrado algumas vezes ao longo deste estudo. Assim, o caso em pauta mostrou-se portador de sequencialidade, de serialidade, não obstante a manutenção de sua carga tímica.

Por conseguinte, impôs-se a questão teórica que guiou esta tese, a qual buscou desvendar, nos mecanismos do discurso do fait divers, as estratégias para "extensivizar" o intenso, que, à maneira do acontecimento, para Zilberberg (2007, 2011a), deveria ser, a priori, muito intenso, mas pouco extenso. A especificidade do Caso Isabella Nardoni contribuiu para que se estabelecessem categorias, as quais foram depreendidas por meio de uma leitura comparativa com outros faits divers.

Diante desse quadro de investigação sobre tal categoria noticiosa, retomamos suas origens na Idade Média e, posteriormente, na imprensa europeia no século XIX, além de levar em conta alguns de seus desdobramentos no Brasil no século XX e XXI. Além disso, abordamos alguns elementos concernentes a esse relato, tais como o sensacionalismo, o melodrama e o folhetim. A essa temática nos dedicamos no Capítulo 1. Vimos aí que o fait divers está estritamente relacionado com o inesperado, impulsionado pelas paixões e que, igualmente, desperta todo o tipo de estados emocionais em quem os lê ou assiste. Podemos dizer, na esteira da 
semiótica tensiva, que um fait divers, em geral, é um fato semiótico, portador de um agudo quantum afetivo, que adentra o campo de presença do sujeito com forte impacto, deixando-o atordoado. Desse modo, não é demais ratificar que a categoria noticiosa do fait divers, assim como o acontecimento para Zilberberg $(2007,2011$ a), rege-se pelo modo concessivo.

Em seguida, apresentamos alguns elementos da semiótica tensiva, no Capítulo 2, para que, com esse aparato teórico-metodológico, pudessem ser realizadas as análises no Capítulo 3. Conforme mencionado na Introdução desta tese, no capítulo dedicado às análises, abordamos de forma mais detida o Caso Isabella Nardoni, mas também outros faits divers foram examinados, com o objetivo de que fosse observado, a partir do "sintagma", o "paradigma” que subjaz à categoria jornalística em questão, para fazer uso dos termos da linguística saussuriana. Desse modo, se o objetivo era analisar essa categoria de relato noticioso, um corpus que englobasse não apenas um fait divers, mas alguns deles, poderia oferecer-nos respostas mais heurísticas no que concerne a uma abordagem tensiva da categoria noticiosa fait divers.

Em relação ao Caso Isabella Nardoni, valemo-nos de alguns eixos analíticos que se mostraram profícuos, uma vez que cada um deles, por meio dos conceitos que os circunscreveram, buscaram, à sua maneira, responder à questão motivadora deste estudo. Os referidos eixos de análise - relação entre fidúcia e concessão; duração e intensidade; a paixão coletiva da comoção; relações intertextuais e interdiscursivas - cumpriram cada qual a tarefa de responder parcialmente o porquê de, não obstante o transcurso da temporalidade, a intensidade em torno do caso enfocado ter sido duradoura.

No que se refere ao primeiro eixo, vimos que a relação entre fidúcia e concessão foi capital para que se mantivesse um interesse crescente do 
enunciatário. Este passou a desempenhar duas operações concessivas: (1) crer no inacreditável, isto é, crer que uma criança fora morta brutalmente, e (2) crer no (ainda mais) inacreditável: a possibilidade de pai e madrasta serem os assassinos. Desse modo, a partir da relação entre surpresa e espera proposta por Valéry, observamos que, a partir de uma surpresa inicial, o sujeito semiótico (enunciatário), passa a um estado de espera tônica, a qual prepara seu espírito para o "ainda pior". Tal espera tensa sobredetermina a expectativa do enunciatário, de modo a explicar a manutenção do interesse em torno do Caso Isabella Nardoni.

O segundo eixo analítico se deteve na relação entre duração e intensidade. Nessa subseção, pudemos depreender dois tipos de categorias noticiosas (que podiam estar presentes numa mesma reportagem ou não): as que reverberavam o acontecimento motivador o assassinato de Isabella Nardoni) e aquelas que, por apresentarem novas informações até então desconhecidas, foram denominadas microacontecimentos. A partir delas, o enunciatário se viu obrigado a desempenhar duas funções contrárias: (1) tentar atenuar o impacto do acontecimento motivador do crime por meio da temporalidade e (2) ver seu campo de presença continuamente reativado pela penetração de novos microacontecimentos que não paravam de surgir. Pelo que pudemos demonstrar, a primeira tarefa não poderia ser concluída enquanto não parassem de sobrevir novos microacontecimentos. Desse modo, pode ser explicado, pela contínua tonificação do campo de presença do sujeito (enunciatário), a persistência desse fato semiótico. Por isso, uma das razões que justificam o fato de a intensidade do Caso Isabella Nardoni ter sido duradora foi porque o acontecimento global (entenda-se por isso o acontecimento motivador, os microacontecimentos $\mathrm{e}$ as respectivas reverberações) demorou a se configurar plenamente. 
No terceiro eixo analítico abordamos a paixão coletiva da comoção que subjaz a eventos midiáticos portadores de uma alta carga tímica e de uma considerável duração. Na esteira de Zilberberg (2011a), pudemos observar que essa ebulição de afetos de um actante coletivo, figurativizado por um ator também coletivo, corresponde à não voz, ao limiar do discurso, que concerne ao acontecimento. Esse estado emocional de caráter público, pelo ponto de vista da semiótica tensiva, corresponde a uma demanda de temporalidade para que o sujeito dê conta de converter, ao menos parcialmente, o sensível em inteligível. Vimos ainda, a partir das reflexões da sociossemiótica de Landowski (2004), que esse "sentir-comum" é o que permite a constituição do tecido social, que vai além de um pacto racional, pois se baseia, fundamentalmente, numa comunidade de gostos e afetos.

O quarto eixo analítico pelo qual analisamos a cobertura realizada pelo Jornal Nacional sobre o Caso Isabella Nardoni pautou-se pelas relações intertextuais e interdiscursivas que esse fait divers permite estabelecer com outros textos/discursos.

No que tange à intertextualidade, valemo-nos da relação entre o caso em pauta com dois contos maravilhosos dos irmãos Grimm, balizados pela figura madrasta, termo sobejamente utilizado pelo enunciador "noticiário" para se referir à esposa de Alexandre Nardoni, àquela época, suspeita. Vimos que, pelos estereótipos que repousam no imaginário humano, o uso de madrasta, termo disfórico, já emitia uma condenação a Anna Carolina Jatobá. Esse ator do nível discursivo, por intertextualidade, passou a se relacionar com as madrastas, sujeitos movidos por paixões malevolentes, dos contos de fada. Assim a expectativa da punição do ator Anna Carolina Jatobá 
contribuiu para que se mantivesse um elevado grau de expectativa por parte do enunciatário.

No âmbito da interdiscursividade, vimos que o Caso Isabella Nardoni pôde ser relacionado com o romance de enigma, que, para Todorov (2006), conta com duas histórias: a do crime e a do inquérito. O caso enfocado mostrou que a busca de indícios, o contraste dos depoimentos, etc. fizeram do Caso Isabella Nardoni uma espécie de romance policial televisionado, cuja expectativa em torno da resolução, de seu desvendar, mostrou-se cada vez mais tônica.

Cabe destacar ainda elementos da linguagem sisual, inerentes ao texto sincrético analisado, que puderam, juntamente com o texto verbal, engendrar sentidos ora contratuais ora polêmicos. Pela metodologia utilizada para captar o vídeo - por meio de quadros/frames - vimos de forma recorrente um visual marcado por um enquadramento (espaço) fechado, um andamento acelerado e um forte impacto. Ademais, a enunciação sincrética do Caso Isabella Nardoni mostrou, muitas vezes, uma dissociação entre o visual, modalizado pelo crer-ser, e pelo verbal, modalizado pelo querer-saber.

Por meio desses eixos analíticos, pudemos depreender, por catálise, um enunciatário marcado por uma espera tensa, cindido entre duas operações antagônicas: querer atenuar o impacto do acontecimento, ao mesmo tempo em que o acontecimento reverberava ou irrompiam novos microacontecimento: ou seja, o sujeito quer, mas não pode. Pelas análises, ainda verificamos a presença de um enunciatário comovido, cujo estado emocional funciona à maneira de uma liga, fazendo dele parte de um todo coletivo, social. Esse mesmo enunciatário mostrou-se modalizado pelo querer-saber, cuja expectativa era também sobredeterminada por outros 
textos e discursos com os quais o caso em questão estabelecia relações intertextuais e interdiscursivas. É, em suma, um enunciatário que se configura na tensão e na complexidade dos eixos da intensidade e da extensidade.

Na parte das análises dedicadas à leitura semiótica de outros faits divers puderam ser observadas algumas invariantes em relação a esse relato jornalístico. Todos eles se ancoram numa base concessiva, todos eles são perpassados por uma lógica passional, patêmica. Entretanto, nem todos se pautam por uma duração considerável. Vimos ainda que apenas uma mesma temática brutal - tal como a do Caso Isabella Nardoni e a do bebê espancado até a morte - não é responsável pela manutenção do interesse do enunciatário por um determinado fait divers.

Elementos da narrativa, a modalização pelo querer-saber, pelo crer-ser ou pelo saber, mostraram-se um ingrediente indispensável: no Caso Isabella Nardoni, embora o enunciatário cresse-ser, ele não-sabia-ser e, portanto, queria-saber; no caso do bebê, ele sabia-ser, o que fez com que o interesse fosse logo aplacado.

Ademais, elementos do discurso - os atores, no primeiro caso, uma criança branca e de classe média; no segundo um bebê negro e pobre mostram que tais elementos não são indiferentes à criação e à manutenção de um querer-saber contínuo e intenso por parte do enunciatário. O mesmo se pode dizer de uma moça "bem educada, inteligente e bonita", conforme textualmente afirmou a revista Época. Esse fator, aliado às circunstâncias do assassinato dos próprios pais, fizeram do Caso Richthofen um fait divers de caráter duradouro. Por isso, mostra Barros (2002, p. 124) que "as figuras são, por excelência, o lugar do ideológico no discurso". 
Portanto, cabe sublinhar mais uma vez que o nível da tensividade, do contínuo, não se dissocia dos demais patamares do sentido. Dessa forma, o contínuo só o é na relação com o descontínuo e vice-versa. Por isso, como já foi dito, a semiótica tensiva não prescinde da semiótica clássica, mas a complementa.

Assim, por meio da teoria e das análises apresentadas, chegamos a duas categorias concebidas sob a égide da tensividade isto é, da relação sine qua non entre intensidade e extensidade, a saber: duração e memória, além do elemento constitutivo paixões. Depreender tais categorias pela ótica tensiva nos autoriza a dizer, ao contrário do que postula Barthes (1964), que o fait divers pode ter duração e memória, mas que não necessariamente sempre as terá. Estudar mais detidamente um fait divers "raro", tal como nos termos da semântica extensiva, para depois cotejá-lo com outros "comuns", e também outros "raros", possibilitou-nos, pois, teorizar, semiotizar, em suma, observar o fait divers por um viés tensivo, que, tal como dissemos, não o aprisiona numa temporalidade forçosamente curta e numa memória igualmente breve.

Finalmente, verificamos que a estratégia de "extensivizar" o intenso por meio da análise de um fait divers durativo - articula, correlaciona, coloca em tensão as duas grandes orientações discursivas nas quais se baseia o imaginário humano: o acontecimento e o exercício. 
"Puisqu'il n'y a pas de langage de la vérité, il ne peut y avoir de langage de la fiction; il n'y a plus de discours littéraire, puisque tout est littérature."

Algirdas Julien Greimas

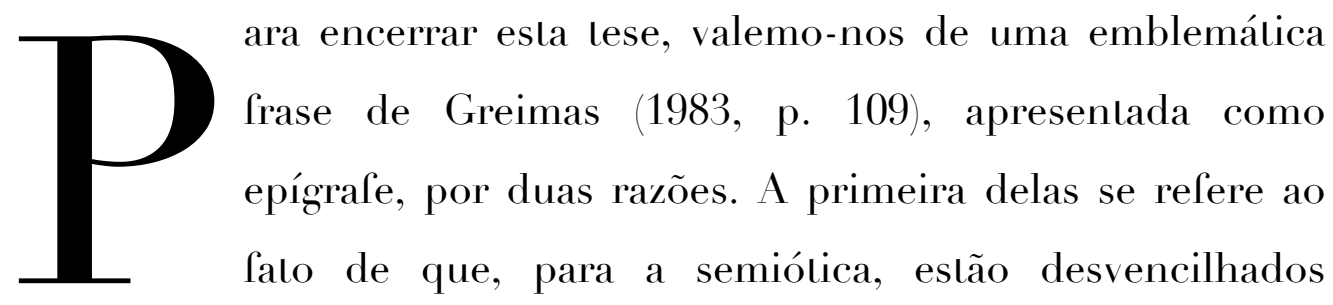
linguagem e referente extralinguístico. A segunda, derivada da primeira, diznos do caráter verossimilhante e, sobretudo, veridictório do fait divers. Cientes de nossa condição de homo symbolicus, sabemos que o real jamais nos será ofertado senão pelas mãos da linguagem.

Os manuais de jornalismo apregoam que o fazer do profissional da notícia deve ser pautado pela busca da verdade. Por essa perspectiva realista ingênua, de acordo com a expressão hjelmsleviana, a linguagem seria tão somente uma ferramenta da ontologia, simples etiquetas que nomeiam as coisas pré-existentes a ela.

Ora, a verdade "nua e crua" - para usarmos mais uma artimanha da linguagem - é inapreensível. Não se pode romper a barreira que a própria linguagem nos impõe a essa "verdade em si". Desse modo, se não há real senão através da linguagem, não há verdades absolutas, mas versões, histórias, narrativas em sentido lato. Por conseguinte, uma vez que a expressão de um conteúdo pressupõe linguagem, seria inocente pensar que a comunicação ótima resultaria de uma transferência cristalina de 
informações de um espírito a outro, tal como seria um hipotético diálogo entre anjos, como aponta Parret (2002, p. 21, 39).

O Caso Isabella Nardoni e outros, aqui analisados sob a rubrica do fait divers, podem não corresponder aos "acontecimentos do mundo" tais como eles se passaram. Entretanto, não é esse o foco da investigação, uma vez que uma definição de fait divers, segundo Barthes (1964, p. 194), é "uma informação monstruosa" (itálicos nossos). As ocorrências mundanas, portanto, são enformadas pela linguagem e, posteriormente, estampadas nas páginas dos jornais, televisionadas, etc. Por isso, como afirma Greimas, não há linguagem da verdade, posto que tudo é literatura. "As coisas mesmas", por essa perspectiva, são, em suma, um efeito de discurso, esta unidade decomponível e fascinante.

Pelas análises que realizamos, pelas categorias depreendidas e pela teorização para esse tipo de relato noticioso, vimos que o fait divers pode corresponder, muitas vezes, ao acontecimento zilberberguiano, que deixa o sujeito atônito. Pode possuir uma carga tímica não tão paroxística e penetrar no espaço tensivo de forma menos abrupta aumentando paulatinamente sua intensidade com o passar do tempo até saturar o campo de presença do sujeito semiótico. Pode durar mais ou menos no eixo da temporalidade. Pode ser esquecido quase que imediatamente à sua leitura/audiência. Pode, entretanto, ficar potencializado de forma tônica na memória coletiva.

Ao analisar o fait divers pela perspectiva da semiótica, desobrigamonos de qualquer correspondência entre linguagem e mundo extralinguístico. Interessa-nos sobretudo sua arquitetura, seu modus operandi, o que já não é pouco. Se aceder ao real só é possível na e pela linguagem, o ato de 
examiná-la, destrinchá-la, permite-nos, pois, chegar às formas - na acepção hjelmsleviana - que, enfim, dão sentido a tudo o que somos.

$\curvearrowright$ 


\section{[Referências]}


ALENCAR, Maria Amorim de. O que é o fait divers: considerações a partir de Roland Barthes. In: CASANOVA, Vera; GLENADEL, Paula (Org.). Viver com Barthes. Rio de janeiro: Sete Letras, 2005, v. 1, p. 115-128.

AMARAL, Márcia Franz. Jornalismo popular. São Paulo: Contexto, 2011.

ANGRIMANI, Danilo. Espreme que sai sangue: um estudo do sensacionalismo na imprensa, 2a . ed. São Paulo: Summus Editorial, 1995.

ASSOCIAÇÃO BRASILEIRA DE RÁDIO E TELEVISÃO. Site. Disponível em: http://abert.org.br/site/index.php?/noticias/todas-noticias/ibge-divulgadados-estatisticos-de-radio-e-tv.html/. Acesso em: jul. 2012.

ASSOCIAÇÃO NACIONAL DE JORNAIS. Site. Disponível em: http://www. anj.org.br/a-industria-jornalistica/jornais-no-brasil/maiores-jornais-do-brasil Acesso em: jul. 2012.

BABO-LANÇA, Isabel. Acontecimento e memória. In: FRANÇA, Vera Regina Veiga; OLIVEIRA, Luciana de. Acontecimento: reverberações. Belo Horizonte: Autêntica, 2012.

BAKHTIN, Mikhail Mikhailovich. Estética da criação verbal. 4. Ed. Tradução de P. Bezerra. São Paulo: Martins Fontes, 2003.

BARBEIRO, Heródoto; LIMA, Paulo Rodolfo de. Manual de telejornalismo: os segredos da notícia na TV. Rio de Janeiro: Elsevier, 2002.

BARROS, Diana Luz Pessoa de. Paixões e apaixonados: exame semiótico de alguns percursos. Cruzeiro Semiótico, 11/12, 1990. p. 60-73.

Teoria do discurso: fundamentos semióticos. $3^{\mathrm{a}}$ ed. São Paulo: Humanitas/USP, 2002.

. Teoria semiótica do texto. São Paulo: Ática, 2007.

. Uma reflexão semiótica sobre a "exterioridade" discursiva. Revista Alfa. n. 53, v. 2, p. 351-364, 2009.

BARTHES, Roland. Structure du fait divers. In: Essais critiques. Paris: Seuil, 1964.

Estrutura da notícia. In: Crítica e verdade. Tradução de L.

Perrone-Moisés. São Paulo: Perspectiva, 1970.

Estrutura do caso do dia. In: Ensaios críticos. Tradução de

A. Massano e I. Pascoal. Lisboa: Edições 70, 2009. 
O efeito de real. In:

O rumor da língua. Tradução de M.

Laranjeira. 3a ed. São Paulo: WMF Martins Fontes, 2012.

BBC. Site. Brazilian girl's parents arrested. Disponível em: http://news.bbc. co.uk/2/hi/americas/7390390.stm. Acesso em jul. 2012.

BEIVIDAS, Waldir. Inconsciente et verbum: psicanálise, semiótica, ciência, estrutura. São Paulo: Humanitas-FLCH/USP, 2002.

. Pulsão, afeto e paixão: psicanálise e semiótica. Revista Psicologia em estudo. V. 11, p. 391-398, 2006.

- Reflexões sobre o conceito de imanência em semiótica: por uma epistemologia discursiva. CASA. Cadernos de Semiótica Aplicada, v. 6, p. 1-13, 2008.

Inconsciente e sentido: psicanálise, linguística, semiótica. São Paulo: Annablume, 2009.

A dimensão do afeto em semiótica: entre fenomenologia e semiologia. In: MARCHEZAN, Renata Coelho; CORTINA, Arnaldo; BAQUIÃ̃, Rubens (Org.). A abordagem dos afetos na semiótica. São Carlos: Pedro \& João Editores, 2011. p. 13-34.

BEIVIDAS, Waldir; RAVANELLO, Tiago. Reflexões sobre o discurso: a linguagem como re-criação do mundo. In: LARA, G. M. P. (Org.). Lingua(gem), texto, discurso. Entre a reflexão e a prática. Rio de Janeiro: Lucerna; Belo Horizonte: FALE/UFMG, 2006.

Alfa, $50(1), 129-144,2006$.

Identidade e identificação: entre semiótica e psicanálise.

BENVEnISTE, Émile. Problemas de linguística geral I. Tradução de M. G. Novak e M. L. Neri. 5 ed. Campinas: Pontes, 2005.

Problemas de linguística geral II. Tradução de E. Guimarães. 2 ed. Campinas: Pontes, 2006.

BERTRAND, Denis. Caminhos da semiótica literária. Tradução de I. C. Lopes et al. Bauru, SP: EDUSC, 2003.

BISTANE, Luciana; BACELLAR, Luciane. Jornalismo de TV. São Paulo: Contexto, 2010. 
BONNER, William. Jornal Nacional: modo de fazer. Rio de Janeiro: Editora Globo/ Memória Globo, 2009.

BRAGA, Claudia; PENJON, Jacqueline. Apresentação. In: THOMASSEAU, Jean-Marie. O melodrama. Tradução de C. Braga e J. Penjon. São Paulo: Perspectiva, 2005.

BUCCI, Eugênio. O telespectador como protagonista (Prefácio). In: TRAVANCAS, Isabel. Juventude e televisão. São Paulo: Ed. FGV, 2007. p. 920.

CARVALHO, Alexandre; DIAMANTE, Fábio; BRUNIERA, Thiago; UTSCH, Sérgio. Reportagem na TV: como fazer, como produzir, como editar. São Paulo: Contexto, 2010.

CHRYSTUS, Mirian. À sombra de Heródoto: a linhagem narrativa das matérias edificantes do Jornal Nacional. 1999. 151 f. Dissertação (Mestrado em Processos Comunicativos e Práticas Sociais) - Faculdade de Letras da Universidade Federal de Minas Gerais, Belo Horizonte, 1999.

- Claro enigma: a dicção nacionalista em pactos literários e jornalísticos. 2007. 247 f. Tese (Doutorado em Literatura Comparada) Faculdade de Letras da Universidade Federal de Minas Gerais, Belo Horizonte, 2007.

DINIZ, Maria Lúcia Vissotto Paiva; PORTELA, Jean Cristtus (Org.). Semiótica e mídia: textos, práticas, estratégias. Bauru: Ed. da UNESP/FAAC, 2008.

DISCINI, Norma. Intertextualidade e conto maravilhoso. São Paulo: Humanitas, 2004 .

O estilo nos textos: história em quadrinhos, mídia e literatura. 2 ed. São Paulo: Contexto, 2009.

DION, Sylvie. O fait divers como gênero narrativo. Revista Letras (UFSM), v. 34, p. 123-131, 2007.

DOSSE, François. A História do Estruturalismo: o campo do signo 1945/1966. vol. 1. Tradução de A. Cabral. Bauru/SP: EDUSC, 2007.

ECO, Umberto. Como se faz uma tese. Tradução de G. C. C. Souza. 24 ed. São Paulo: Perspectiva, 2012. 
El País. Brasil, conmocionada [sic] por la muerte a manos de su ex novio de una chica de 15 años. Disponível em: http://internacional.elpais.com/inter nacional /2008/10/19/actualidad/ 1224367206_850215.html/. Acesso em 10 abr. 2013.

ÉPOCA. Site. No rastro de Suzane. Disponível em: http://revistaepoca. globo.com/Revista/Epoca/0,,EDR54308-5990,00.html. Acesso em 9 abr. 2013.

FECHINE, Yvana. Televisão e presença: uma abordagem semiótica da transmissão direta. São Paulo: Estação das Letras e Cores, 2008.

FELTRIN, Ricardo. Ibope do 'Jornal Nacional' no país cresce com Patrícia Poeta. In: F5. Site. Disponível em: http://55.Folha.uol.com.br/colunistas/ ricardofeltrin/1087708-ibope-do-jornal-nacional-no-pais-cresce-com-patricia -poeta.shtml/. Acesso em: jul. 2012.

FIORIN, José Luiz. Sobre a tipologia dos discursos. In: Significação Revista Brasileira de Linguística. Araraquara, v. 8/9, p. 91-98, 1990.

2003. p. 19-52.

O projeto hjelmsleviano e a semiótica francesa. Revista Galáxia, $\mathbf{n}^{\circ} 5$, . Linguagem e ideologia. 8 ed. São Paulo: Ática, $2005 a$.

- As astúcias da enunciação: as categorias de pessoa, espaço e tempo. 2 ed. São Paulo: Ática, 2005b.

. Elementos de análise do discurso. 14 ed. São Paulo: Contexto, 2006.

- A semiótica discursiva. In: LARA, Glaucia Muniz Proença; MACHADO, Ida Lucia; EMEDIATO, Wander (Org.). Análises do discurso hoje. Vol. 1. Rio de Janeiro: Nova Fronteira, 2008. p. 121-144.

FONTANILLE, Jacques; ZILBERBERG, Claude. Tensão e significação. Tradução de I. C. Lopes; L. Tatit e W. Beividas. São Paulo: Humanitas, 2001.

Semiótica do discurso. Tradução de J. C. Portela. São Paulo: Contexto, 2007.

. Pratiques sémiotiques. Limoges: PULIM, 2008.

Práticas semióticas: imanência e pertinência, eficiência e otimização.

In: DINIZ, Maria Lúcia Vissotto Paiva; PORTELA, Jean Cristtus (Org.). Semiótica e mídia: textos, práticas, estratégias. Bauru: UNESP/FAAC, 2008. 
FOUCAULT, Michel. Os assassinos que se conta (sic). In: Eu, Pierre Rivière, que degolei minha mãe, minha irmã e meu irmão. Tradução de D. L. Almeida. 5 ed. Rio de Janeiro: Graal, 1977. p. 211-221.

FOLHA DE S. PAULO. Site. Assassinato do casal Richthofen completa um ano. Disponível em: http:/www1.folha.uol.com.br/folha/cotidiano/ult95u 84892.shtml. Acesso em 9 abr. 2013.

Saiba como foi a morte do casal Richthofen, segundo a polícia. Disponível em: http:/www1.folha.uol.com.br/folha/cotidiano/ult95u62515. shtml. Acesso em 9 abr. 2013.

Mais longo caso de cárcere privado em SP completa 3 dias; negociações prosseguem. Disponível em: http://www1.folha.uol.com.br/ folha/cotidiano/ult95u456836.shtml. Acesso em 10 abr. 2013.

. Peça de teatro sobre caso Isabella Nardoni estreia em SP em março. Disponível em: http://www1.folha.uol.com.br/ilustrada/1220042-peca-deteatro-sobre-caso-isabella-nardoni-estreia-em-sp-em-marco.shtml/. Acesso em 13 abr. 2013.

- Manual de Redação da Folha de S. Paulo. Disponível em: www1.folha.uol.com.br/folha/circulo/manual_redacao.htm. Acesso em: 22 abr. 2013.

FRANÇA, Vera Regina Veiga; CORRÊA, Laura Guimarães. Apresentação. In: Mídia, instituições e valores. (Org.). Belo Horizonte: Autêntica, 2012.

FREUD, Sigmund. O mal-estar na cultura. Tradução de R. Zwick. Porto Alegre, RS: L\&PM, 2010.

G1. Site. Número de mulheres estupradas em festa na PB sobe para 6 , diz delegada. Disponível em: http:/g1.globo.com/paraiba/noticia/2012/02/num ero-de-mulheres-estupradas-em-festa-na-pb-sobe-para-6-diz-delegada.html/. Acesso em jul. 2012.

. Condenação de Suzane Richthofen pela morte dos pais completa 4 anos. Disponível em: http://g1.globo.com/sao-paulo/noticia/2010/07/condena cao-de-suzane-richthofen-pela-morte-dos-pais-completa-4-anos.html/. Acesso em 9 abr. 2013.

Jovem baleada após sequestro no ABC tem morte cerebral, diz equipe médica. Disponível em: http://g1.globo.com/Noticias/SaoPaulo/0,,mul 
804318-5605,00-jovem + baleada + apos + sequestro + no + abc + tem + morte + cereb ral + diz + equipe+medica.html. Acesso em: 10 abr. 2013.

GOMES, Itania Maria Mota et al. Modo de Endereçamento no Telejornalismo do Horário Nobre Brasileiro: o Jornal Nacional, da Rede Globo de Televisão. Trabalho apresentado ao NP 07 - Comunicação Audiovisual, no XXVIII Congresso Brasileiro de Ciências da Comunicação Intercom, Rio de Janeiro, 2005.

GOMES, Regina Souza. Aspectualização e modalização no jornal: expectativa e acontecimento. Estudos Semióticos. Volume 8, Número 2, São Paulo, Novembro de 2012, p. 11-20.

GREIMAS, Algirdas Julien. Du sens: essais sémiotiques. Paris: Éditions du Seuil, 1970.

. Semântica estrutural. Tradução de H. Osakape e I. Blikstein. São Paulo: Cultrix/EdUSP, 1973.

"L'Énonciation: une posture épistémologique". In: Significação Revista Brasileira de Semiótica, $\mathrm{n}^{\mathrm{0}}$ 1, Centro de Estudos Semióticos A. J. Greimas: Ribeirão Preto (SP), 1974, p. 09-25.

Semiótica do discurso científico: da modalidade. Tradução de C. T. Paes. São Paulo: Difel, 1976.

.; LANDOWSKI, Eric. Analyse sémiotique d'un discours juridique. In: GREIMAS, Algirdas Julien. Sémiotique et sciences sociales. Paris: Seuil, 1976. P. 77-128.

. Du sens II: essais sémiotiques. Paris: Éditions du Seuil, 1983.

. Del sentido II: ensayos semióticos. Traducción de Esther Diamante. Madrid: Editorial Gredos, 1989.

; FONTANILLE, Jacques. Sémiotique des passions: des états de choses aux états d'âme. Paris: Éditions du Seuil, 1991.

; ___ Semiótica das paixões: dos estados de coisas aos estados de alma. Tradução de M. J. R. Coracini. São Paulo: Ática, 1993.

Da imperfeição. Tradução de A. C. Oliveira et al. Hacker editores: São Paulo, 2002. 
Semiótica figurativa e semiótica plástica. Tradução de I. A. Silva. In: OLIVEIRA, Ana Claudia de (Org.). Semiótica plástica. São Paulo: Hacker Editores, 2004.

; COURTES, J. Sémiotique: dictionnaire raisonné de la théorie du langage. Tome II. Paris: Hachette, 1986.

; Semiótica: diccionario razonado de la teoría del lenguaje. Tomo II. Traducción de Enrique Ballón Aguirre. Madrid: Editorial Gredos, 1991.

; ___ Dicionário de semiótica. São Paulo: Contexto, 2008.

GUIMARÃES, Valéria. Notícias Diversas: apontamentos para a história do fait divers no Brasil. Revista PJ:Br (ECA-USP), v. 7, 2006.

GRIMM, Jacob; GRIMM, Wilhelm. Contos maravilhosos infantis e domésticos Tomo 1 [1812]. Tradução de C. Röhrig. São Paulo: Cosac Naify, 2012.

HEBERT, Louis. Tools for text and image analysis: an introduction to applied semiotics. Quebec: Texto!, 2006 [online]. Disponível em: <http:/www.revuetexto.net/Parutions/Livres-E/Hebert_AS/Hebert_Tools.html $>$. Acesso em: 14/02/2013.

HJELMSLEV, Louis. Le langage. Traduit du danois par M. Olsen. Préface de A. J. Greimas. Paris: Les Éditions de Minuit, 1971.

Perspectiva, 1991.

Ensaios linguísticos. Tradução de A. P. Danesi. São Paulo: - Prolegômenos a uma teoria da linguagem. Tradução de J. Teixeira Coelho Neto. São Paulo: Perspectiva, 2006.

HERNANDES, Nilton. A mídia e seus truques: o que jornal, revista, TV, rádio e internet fazem para captar e manter a atenção do público. São Paulo: Contexto, 2006.

HOUAISS, Antônio; VILLAR, Mauro de Salles. Dicionário Houaiss da língua portuguesa. Rio de Janeiro: Objetiva, 2001.

HUPPES, Ivete. Melodrama: gênero e sua permanência. São Paulo: Ateliê Editorial, 2000.

JORNAL NACIONAL. Site. Disponível em: http://jornalnacional.globo. com/. Acesso em: jun. 2008. 
LANDOWSKI, Eric. Situation; socio-sémiotique. In: GREIMAS, Algirdas Julien; COURTÉS, Joseph. Sémiotique: dictionnaire raisonné de la théorie du langage. Tome II. Paris: Hachette, 1986. p. 172-173.

- A sociedade refletida: ensaios de sociossemiótica. Tradução de E. Brandão. São Paulo: Pontes, 1992.

O livro de que se fala. In: GREIMAS, Algirdas Julien. Da imperfeição. Tradução de A. C. Oliveira et al. Hacker editores: São Paulo, 2002. p. $125-150$.

Passions sans nom: essais de socio-sémiotique III. Paris: Presses Universitaires de France, 2004.

Prefácio. In: FECHINE, Yvana. Televisão e presença: uma abordagem semiótica da transmissão direta. São Paulo: Estação das Letras e Cores, 2008.

LAPLANCHE, Jean; PONTALIS, Jean-Bertrand. Vocabulário de psicanálise. 4. ed. São Paulo: Martins Fontes, 2001.

LARA, Glaucia Muniz Proença Lara; MATTE, Ana Cristina Fricke. Ensaios de semiótica: aprendendo com o texto. Rio de Janeiro: Nova Fronteira, 2009.

. ; MENDES, Conrado Moreira. Exterioridade discursiva no conto "A Ceia", de Lygia Fagundes Telles: por uma perspectiva semiótica. Revista de Estudos da Linguagem (UFMG), v. 19, p. 105-126, 2012.

; Formas de vida e política. In: FULANETI, Oriana N.;

BUENO, Alexandre Marcelo (Org.). Linguagem e política: princípios teóricodiscursivos. São Paulo: Contexto, 2013. p.143-162.

LAROUSSE, Pierre. Fait divers. In: Grand Dictionnaire universel du XIXe siècle. Vol. 8. Paris: Librairie Classique Larousse et Boyer, 1866-1875. p. 58.

LAVILLE, Christian; DIONNE, Jean. A construção do saber: manual da pesquisa em ciências humanas. Tradução de H. Monteiro e F. Settineri. Porto Alegre: Artmed; Belo Horizonte: Editora UFMG, 1999.

LE MONDE. Le sourire d'Isabella hante le Brésil. Disponível em: http://www.lemonde.fr/cgi-bin/ACHATS/acheter.cgi?offre=ARCHIVES\& type_item=ART_ARCH_30J\&objet_id=1035904. Acesso em jul. 2012.

LEVINAS, Emmanuel. Le temps et l'autre. 10 ed. Paris: PUF, 2011. 
LIMA, Eliane Soares de. Entre enunciador e enunciatário: um estudo sobre a compaixão. 128f. Dissertação (Mestrado) - Faculdade de Filosofia, Letras e Ciências Humanas, Universidade de São Paulo, 2010.

LOPES. Ivã Carlos. Esquematização da modalidade epistêmica. In: CORTINA, Arnaldo; MARCHEZAN, Renata Coelho. Razões e sensibilidades: a semiótica em foco. Araraquara: Cultura Acadêmica, 2004. p. 51-65.

MACHADO, Arlindo. A televisão levada a sério. São Paulo: Editora SENAC, 2000 .

MAFFESOLI, Michel. Une forme d'agrégation tribale. In: Revue Autrement, Faits-divers, $\mathrm{N}^{\circ}$ 98, Avril 1988. p. 90-98.

MAZZARI, Marcus. Apresentação. In: GRIMM, Jacob; GRIMM, Wilhelm. Contos maravilhosos infantis e domésticos -Tomo 1 [1812]. São Paulo: Cosac Naify, 2012.

MEDEIROS, João Bosco. Redação científica: a prática de fichamentos, resumos, resenhas, 11. ed. São Paulo: Atlas, 2012.

MENDES, Conrado Moreira. O falar do Jornal Nacional: produção e recepção de um sotaque de natureza ideológica. 2006. 106 f. Monografia (Conclusão do curso de Comunicação Social - Habilitação Jornalismo) - Universidade Federal de Minas Gerais, Belo Horizonte, 2006.

- A expressão e o conteúdo da fala do Jornal Nacional. 2009. 207 f. Dissertação (Mestrado em Estudos Linguísticos) - Faculdade de Letras da Universidade Federal de Minas Gerais, 2009.

2010.

A comunicação pela semiótica. Vertentes (UFSJ), v. 36, p. 170-180,

; BEIVIDAS, Waldir. Narrativa e Acontecimento no Caso Isabella: algumas reflexões preliminares. Revista da ANPOLL, v. 01, p. 41-68, 2010.

Acontecimento na enunciação: uma análise do conto "A Ceia", de Lygia Fagundes Telles. Cadernos de Semiótica Aplicada (Unesp-Araraquara), v. 9 , p. 1-14, 2011.

- Da linguística estrutural à semiótica discursiva: um percurso teórico-epistemológico. Raído (UFGD), v. 05, p. 173-193, 2011.

; CHRYSTUS, Mirian. Sobre o Jornal Nacional: um recorte discursivo. Revista Mediação. Belo Horizonte, V. 14, no. 14, jan./jun., 2012. 
A semiotic approach of features. 2nd International Conference on Language, Medias and Culture, 2013, Macau, China. In: TAO, Feng (Org.). Language, Medias and Culture II. Hong Kong: IACSIT Press, 2013. v. 62. p. $50-53$

MENDES, Mariza Bianconcini Teixeira. A ficção seriada na TV brasileira: uma prática sociossemiótica. Estudos Linguísticos, São Paulo, 37 (3): 273-280, set.- dez. 2008.

MENDES, Simone Paula dos Santos. Um estudo da argumentação em cordéis midiatizados: da enunciação performática à construção discursiva da opinião. 2011. 277f. (Doutorado em Estudos Linguísticos) - Faculdade de Letras da Universidade Federal de Minas Gerais, Belo Horizonte, 2011.

MERLEAU-PONTY, Maurice. Sobre as notícias do cotidiano. In:

Signos. Tradução de J. Bruna. São Paulo: Martins Fontes, 1991. pp. 349-352.

Fenomenologia da percepção. Tradução de C. A. R. de Moura. 3 ed. São Paulo: Martins Fontes, 2006.

MEYER, Marlyse. Folhetim: uma história. 2 ed. São Paulo: Companhia das Letras, 1996.

MORIN, Edgard. Cultura de massas no século XX. Vol. 1: Neurose. 10a ed. Tradução de M. R. Sardinha. Rio de Janeiro: Forense Universitária, 2011.

MOTTA, Leda Tenório da. Antígona em São Paulo: um diálogo entre duas tragédias: à luz do teatro grego, caso Isabella evidencia lições sobre o mundo brasileiro. In: O Estado de S. Paulo, 31 mai. 2008. Disponível em: http://www. estadao.com.br/noticias/impresso, antigona-em-sao-paulo-um-dialogo-entreduas-tragedias, 181935,0.htm. Acesso em: ago. 2012.

Iluminuras/FAPESP, 2011.

NOHARA, Jouliana Jordan; ACEVEDO, Claudia Rosa. Monografia no curso de administração: guia completo de conteúdo e forma. 3. ed. São Paulo: Atlas, 2007.

OLIVEIRA, Ana Claudia de. Prefácio. In: GREIMAS, Algirdas Julien. Da imperfeição. Tradução de A. C. Oliveira et al. Hacker editores: São Paulo, 2002. p. 9-18.

A dupla expressão da identidade do jornal. Revista Galáxia, São Paulo, n. 14, p. 63-80, dez. 2007. 
.; TEIXEIRA, Lucia. (Org.) Linguagens na comunicação: desenvolvimentos de semiótica sincrética. São Paulo: Estação das Letras e Cores, 2009.

ORGANIZAÇÕES GLOBO. Jornal Nacional: a notícia faz história. Memória Globo. Rio de Janeiro: Jorge Zahar Ed., 2004.

PARRET, Herman. La voix et son temps. Bruxelles: Éditions De Boeck Université, 2002.

PATERNOSTRO. Vera Iris. O texto na TV: manual de telejornalismo. Rio de Janeiro: Elsevier, 1999.

Portal Imprensa. Seqüestro [sic], cárcere privado e espetáculo midiático. Disponível em: http://portalimprensa.uol.com.br/colunistas/colunas/2008/ 10/18/imprensa 311.shtml/. Acesso em 10 abr. 2013

PORTELA, Jean Cristtus. Semiótica midiática e níveis de pertinência. In: DINIZ, Maria Lúcia Vissotto Paiva; . (Org.). Semiótica e mídia: textos, práticas, estratégias. Bauru: UNESP/FAAC, 2008.

PRADO, Adélia. Poesia reunida. São Paulo: Siciliano, 2001.

PROPP, Vladimir. Morphologie du conte. Paris: Éditions de Seuil, 1965.

RAMOS, Roberto. Caso Isabella: uma leitura semiológica. Significação (USP). No 30. Primavera/verão, 2008. p. 137-147.

Os sensacionalismos do sensacionalismo: uma leitura dos discursos midiáticos. Porto Alegre: Sulina, 2012.

REDE GLOBO DE TELEVISÃO. Site. Direção Geral de Comercialização. Disponível em: http://comercial.redeglobo.com.br/programacao_jornalismo /jnac5_intro.php/. Acesso em: jul. 2012.

REZENDE, Guilherme Jorge de. Telejornalismo no Brasil: um perfil editorial. São Paulo: Summus Editorial, 2000.

ROSA, João Guimarães. A terceira margem do rio. In: . Primeiras estórias. Rio de Janeiro: Nova Fronteira, 2005. p. 77-82.

SAUSSURE, Ferdinand de. Curso de linguística geral. 27. ed. São Paulo: Cultrix, 2006.

SILVERSTONE, Roger. Por que estudar a mídia? Tradução de M. C. Mota. 3 ed. São Paulo: Edições Loyola, 2002. 
SODRÉ, Muniz. As estratégias sensíveis: afeto, mídia e política. Petrópolis/RJ: Vozes, 2006.

A narração do fato: notas para uma teoria do acontecimento. Petrópolis/RJ: Vozes, 2009.

TERRA. Site. Jornais impressos sobrevivem e ainda crescem no Brasil, comemoram editores. Disponível em: http:/noticias.terra.com.br/mundo/ noticias/0,,OI6017558EI294,00J ornais + impressos + sobrevivem $+\mathbf{e}+$ ainda + cres cem + no + Brasil + comemoram + editores.html/. Acesso em: jul. 2012.

TATIT, Luiz. Musicando a semiótica: ensaios. São Paulo: Annablume, 1997. . Semiótica à luz de Guimarães Rosa. São Paulo: Ateliê Editorial, 2010.

THOMASSEAU, Jean-Marie. O melodrama. Tradução de C. Braga; J. Penjon. São Paulo: Perspectiva, 2005.

TODOROV, Tzvetan. Tipologia do romance policial. In: As estruturas narrativas. Tradução de L. Perrone-Moisés. São Paulo, Perspectiva, 2006.

TOMASI. Carolina. A missividade: por uma gramática tensiva da semiótica de HQs. 2011. 281f. Dissertação (Mestrado em Semiótica e Linguística Geral) Faculdade de Filosofia, Letras e Ciências Humanas da Universidade de São Paulo, 2011.

Elementos de semiótica: por uma gramática tensiva do visual. São Paulo: Atlas, 2012.

TRAVANCAS, Isabel. Juventude e televisão. São Paulo: Ed. FGV, 2007.

TRÉSOR DE LA LANGUE FRANÇAISE INFORMATISÉ. Disponível em: http://atilf.atilf.fr/. Acesso em: mai. 2013.

TRUBETZKOY. N. Principes de phonologie. Traduction de J. Cantineau. Paris: Librairie Klincksieck, 2005 [1938].

VALÉRY, Paul. Cahiers I. Édition établie, présentée et annotée par Judith Robinson. Paris: Éditions Gallimard, 1973.

VAZ, Paulo; FRANÇA, Renné. Através do espelho: o acontecimento Isabella na revista Veja. Revista Logos (UFRJ). No 31, ano 17, $2^{\circ}$ semestre 2009. p. 0418.

ZILBERBERG, Claude. Eléments de grammaire tensive. Limoges: Pulim, 2006. 
. Razão e poética do sentido. Tradução de I. C. Lopes, L. Tatit e W. Beividas. São Paulo: Editora da Universidade de São Paulo, 2006a.

Síntese da gramática tensiva. In: Significação. Revista Brasileira de Semiótica. n. 25, p. 163-204. 2006 b.

Louvando o acontecimento. Tradução de M. L. V. P. Diniz. Revista Galáxia. São Paulo, no 13, p. 13-28. jun. 2007.

Éléments de grammaire tensive. Limoges: PULIM, 2006, 244 p. Resenha de: MENDES, Conrado Moreira; RAMOS-SILVA, Sueli Maria. CASA - Cadernos de semiótica aplicada, v. 7 , no 2, p. 01-05, 2009.

. Elementos de semiótica tensiva. Tradução de I. C. Lopes, L. Tatit e W. Beividas. São Paulo: Ateliê Editorial, 2011a.

. Des formes de vie aux valeurs. Paris: PUF, $2011 \mathrm{~b}$. 